\title{
THE FISHERMENS
}

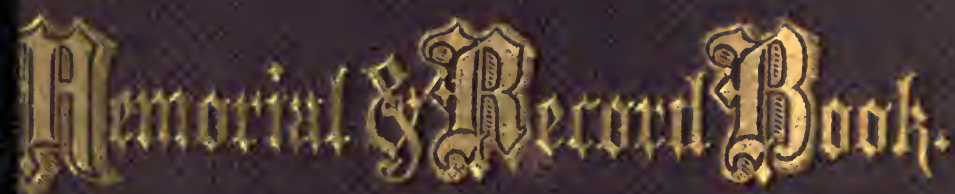



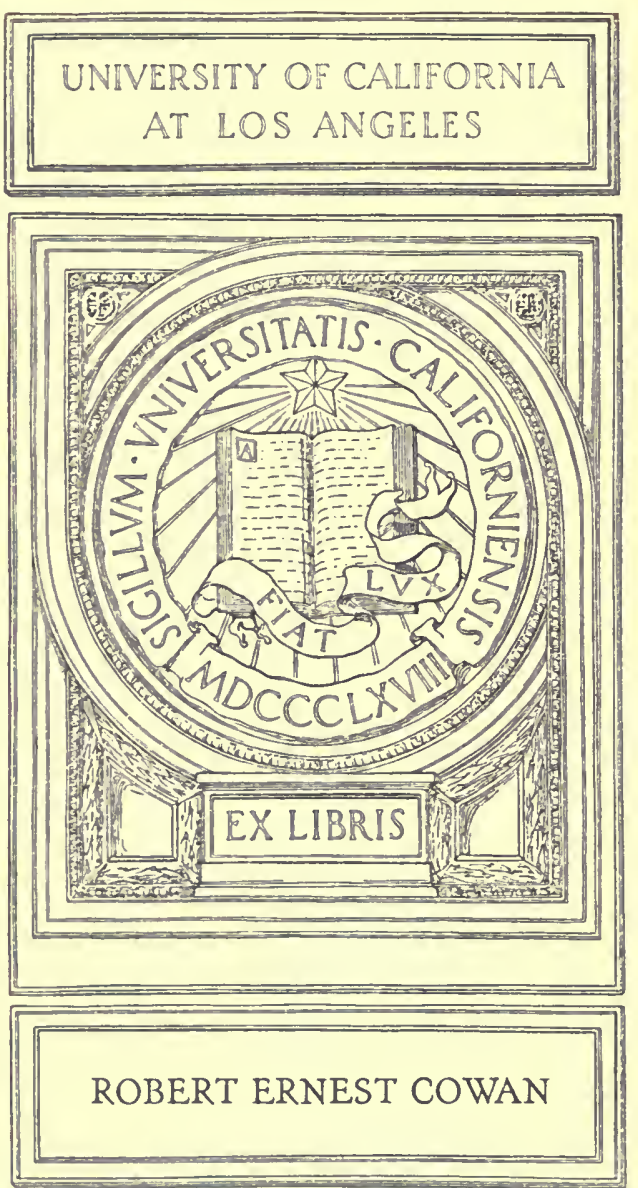
Digitized by the Internet Archive in 2007 with funding from Microsoft Corporation 



\title{
THE FISHERMEN'S
}

\section{geflemotial and gigeroud gigool,}

\author{
B: \\ GEORGE H. PROCTER, \\ contarsing
}

A LIST OF VESSELS AND THEIR CREWS, LOST FROM THE POR'T OF GLOUCESTER FROM THE YEAR 1830 TO OCTOBER 1, 1873,

EMนRACING

A PERIOD OF NEARLY HALF A CENTURY;

CoMprisixa

FOURTEEN HUNDRED AND THIRTY-SETEN NAYES, AND TWO HUNDRED

ASD NINETY-SIX FESSELS, INCLUDING THOSB LOST IN THB GALB OP ALGTST 24, 1873.

IT ALso CONTAIX

VALUABLE GTATISTICS OF THE FISHING BLSINESS, OFF-HAND BKETCIES, BIG TRIPS, TALES OF NARROW EBCAPES, MARTTIME POETRY, AND OTHER MLA TTERS OF INTEREST TO TURSE TOLERS OF THE SEA.

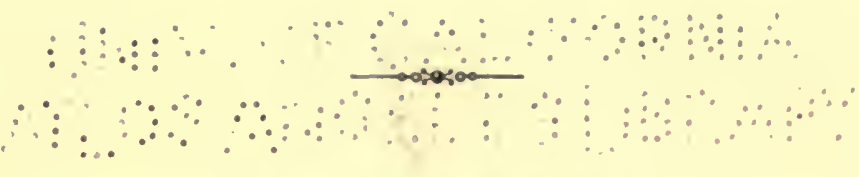

GL OUCESTER :

PROCTER BROTHERS, Publishers, CAPE ANY ADVERTISER OYTCE. 
Entered according to Act of Congress, in the year 1873, by GEORGE H. PROCTER,

In the office of the Librarian of Congress, at Washington.

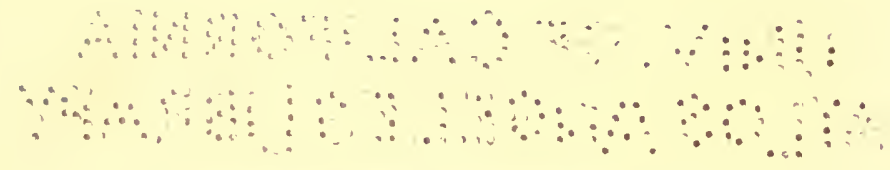

Procter Brothers, Printers, Gloucester, Mass. 


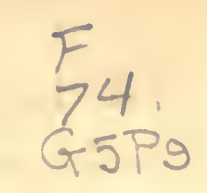

\section{TABLE OF CONTENTS.}

\section{I. - Preface}

II. - Perils attending the Fisheries

III. - List of the Names of Twelve Ilundred and Sixty-five Men and Two

Hundred and Eighty Vessels Lost in the Fisheries and other maritimo branches, from the Port of Gloucester, from the year 1830 to July 1st, 1873, embracing a period of nearly lialf a century; also, the Valuation of the Vessel Property and Insurance therenn . . . . . 8

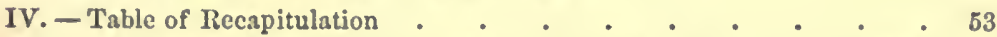

V. - On Georges in the Terrible Gale of February 24th, 1862. The experience of one who was there for the first and last time . . . 54

VI. - The Mackerel Fishery-Giving an Account of its Commencement and Progress, with Statistics of the Catch for the past thirteen years . VII. - The Haddock, Pollock, Cod and IIallbut Fisheries, giving an Account of the First Trips to Georges for Codfish . . . . . 65 VIII. - The Commerce of Gloucester and the Fisheries . . . $\quad 68$ IX. - The Winter Fishery of $1846-\Omega$ Comparison between Then and Now, showing the wonderful Increase of this Branch of the Business. . X. - "Uncle Charlie's" Recollections of the Old Pinkey and Jigger Fleets; also, of the Square Sterners, Half-Clipper and Clipper Model Fishing Vessels.

XI. - $\Delta$ ccount of the First Trips to Georges after Halibut . . . . 77

XII. - Incidents of the Gale of September 8th, 1869 . . . . . 79

XIII. - Sea Fish and Fisheries . . . . . . . . 81

XIV. - Big Trips in the Bank, Georges, Mackerel and Haddock Fisheries 82

XV. - How the Pinkey Charles weathered it . . . . . 87

XVI. - Loss of Two Rockport Vessels. Thrilling Narrative of Mr.

Charles Jordan, sole surviror of the crew of Schooner Helen Eliza.

His Perilous Position and Wonderful Escape . . . .

XVII. - Fishermen's Superstitions. Remarkable Verifications of Dreams.

Wonderful Presentiment . • • • • • • . 92

XVIII. - Greenland and Iceland Halibut Fisheries . . • . 96

XIX. - Estimated Products of the Fisheries for the year 1872. Tonnage Statistics 
XX. - Remarkable Escapes of Schooners Onward and Seddie C. Pyle on Georges - Loss of Schooners A.R.Andrews, and Rescue of her Crew Lost in the Fog - Rescued from the Jaws of Death - Comprising the Details of Narrow Escapes by the Fishermen . • • • 98

XXI. - The Pirate Tacony's Raid upon the Fishermen . . . . 105

XXII. - A Valuable Branch of Industry . . • • • • . 107

XXIII. - Recapture of Schooner E. A. Horton from the Custody of the

Dominion Government-A Daring Act by a Yankee Skipper and his

Crew . . . . . . . . . • • . . 108

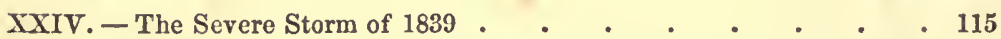

XXV. - Fishermen's children Playing on the Beach . . . . 117

XXVI. - The Cape Ann Fishermen of To-Day . . . . . . 119

XXVII. - How Harry G. came to Sign the Pledge • • • • . 123

XXVIII. - Picking the Nets and Trawls, in which we find a good haul of

Sketches, Incidents and Facts, relative to the Fisherman and his Occupation . . . . . . • • • • . .

XXIX. - Dashings of Spray from Wavelets of Maritime Poetry by Home

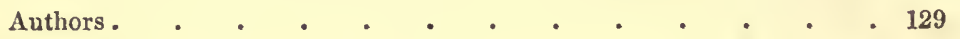

XXX. - A Musical Fisherman - His First Violin - Early Struggles - His

Cruise in The Rival-Shipwrecked Yankee Fishermen Giving Concerts in the Provinces . . . . . . . . . .

XXXI. - Loss of Schooner Neptune's Bride - Two of the Crew saved -

Eighteen hours on the Mast-Head - A Perilous Passage . • .

XXXII. - Leaves from the Log Book of Captain James Pattillo- How He served a Dominion Officer who Boarded the Schooner Abigail - Puts to Sea in the Teeth of a Gale and outsails the Cutter - How he gets a load of Herring for Schooner Tiger - A Fearful Time on Georges in

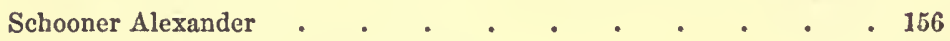
XXXIII. - "Here comes Father's Vessel" . . . . . . 164 XXXIV. - Appendix • • • • • • • • • • 166 XXXV. - The Terrible Gale of Sunday, August 24th, 1873. List of the Lost Men and Vessels . . . . . • • • . 167 XXXVI. - Sum Total of Losses for the past Forty-three Years . . 172 


\section{PREFACE.}

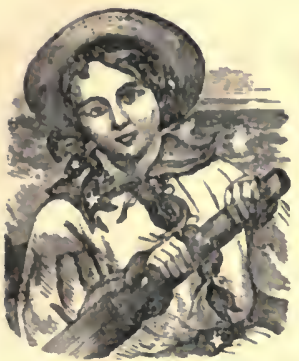

For some time past it has been my desire to prepare a Mesrorial Voluare, which would contain, among other matters of interest to the fishermen, as well as to the large number of vessel owners and fitters, a record which should be as complete as could possibly be gathered, of that vast number who have been lost from the port of Gloucester, while toiling on the fishing-grounds, in the arduous avocation of wresting from old ocean her finny treasures.

Here in this volume are the names of these men recorded, and here will their memories be perpetuated among their slipmates and relatives, and handed down to those who in the years to come shall sail the vessels, haul the lines and nets, in the prosecution of a business which has given to Gloucester a goodly portion of her wealth, and placed her in the position of the largest fishing port in the world.

To the fishermen, the workers - those who have fought the elements at inclement seasons - much of this prosperity is due, and it has been my aim to render the volume of special interest to them and theirs.

To those who have been so kind in furnishing information and ineidents during the canvassing of the past six months, and who by their words of appreciation of the work have so efficiently aided its progress, I return my warmest thauks, as without theil hearty co-operation its pages would not contain such a large array of facts and incidents. Those who have ever undertaken anything of a similar nature, requiring such persistent labor, know full well how much their success depends upon this "interviewing" process, which is, when courteously conducted, the surest means of obt:ining information.

Most especially would I return thanks to JoHn S. F. Rogers, of the Gloncester Telegraph, and to Jous W. Woxsos, for their courtesy in furnishing the means of obtaining information relative to some of the crew lists of vessels lost previous to 1850 . I am also under obligations to Jonx L. Snoner, Fs $s Q_{i}$, ellitor of the Nur- 
sery, Boston, for facilities in obtaining some of the fine engravings which adorn the volume.

And now, sending this, my first-born literary venture in book form into the world, I have in my heart a hope that the fishermen and their families may find it of sufficient interest to insure for this Memorial and Record Book a wolcome place on the home bookshelf, or a snug position among the reading matter on board the vessel.

GEORGE H. PROCTER.

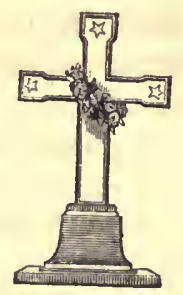




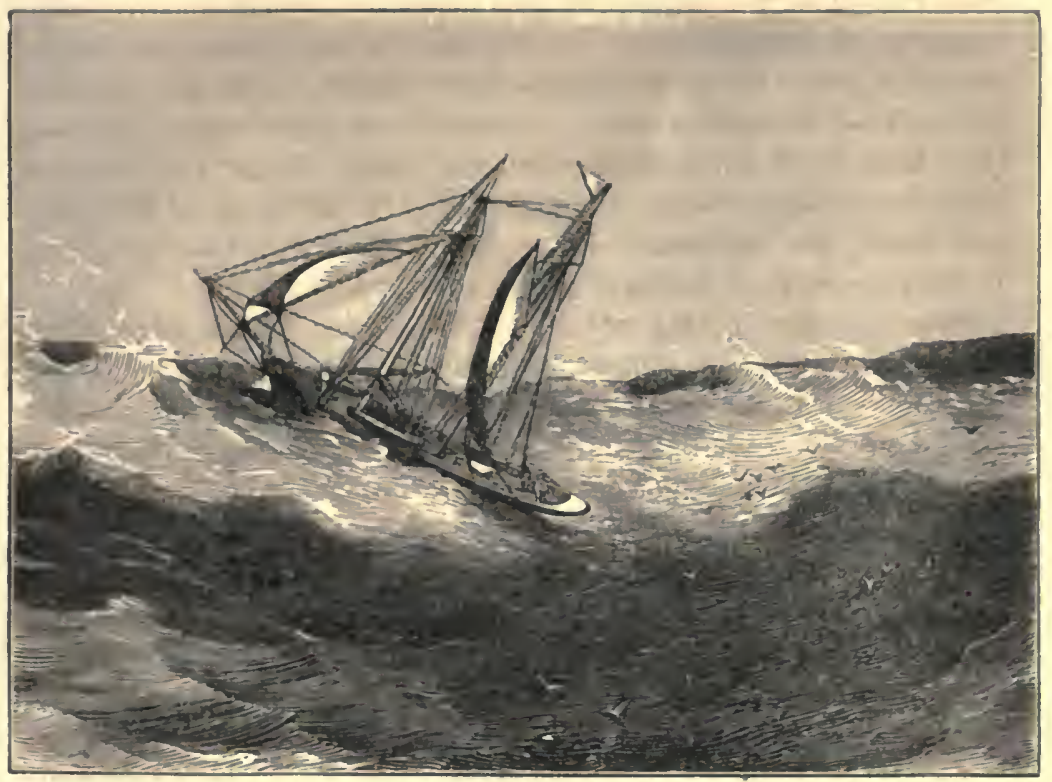

\section{Perils Attending the Fisheries.}

There is scarcely a branch of business in the known world which is pursued with such a fearful loss of life and property as that which attends the fisheries. To watch the pretty crafts when they sail away on their summer cruises for mackerel, gives one an idea that such an avocation is replete with enjoyment. These trips are in reality very pleasant, affording considerable excitement, much jollity, and agreeable labor, which yield good returns; this may well be called the sunny side of the picture, for such it.really is, although during the latter portion of them, in the autumn months, rough weather is often encountered with its accompanying dangers.

When, however, winter comes, and the necessities of the fishermen, many of whom have large families, render it imperative that they must follow winter fishing on Georges or to the Banks, then is presented a far different aspect. The summer with its balmy breezes, pleasant weather, clear skies and placid waters, gives place to the keen blasts, piercing cold, boisterous winds, murky sky and raging waters. Then the thick driving snow-storm, the terrible gales with 
all their accompaniments of disaster and discomfort, requiring the steady hand at the wheel, the firm purpose to meet and overcome obstacles, the determination on the part of these bread-winners to meet the perils which encompass their pathway over the trackless waters, to ride out the storm, if possible, or, under canvas, to keep their little craft safely afloat, until the danger is past and they can once more resume fishing. Danger lurks in the track of the fishermen during the inclement season, and they literally take their lives in their hands when they sail away on their winter trips.

Since the introduction of trawl fishing, some twelve years since, another peril has been added to the fisheries, viz. : that of being lost from the dories while visiting trawls, or estrayed during the fog which oftentimes shuts in on the fishing grounds, enveloping them like a pall. Then the dorymen find it extremely difficult to discover their vessel. A fresh breeze springing up renders the situation still more dangerous, and notwithstanding the efforts made on board, by the firing of guns, blowing of horns, ringing of bells, and the continued cruising about in search of the missing men, the fact of not being enabled to find them, and being obliged to give up the search and return home, is too often the case. There are chances of being picked up by some other vessels of the fleet, or by some merchantman; and there are instances on record where these trawlers, after having given up all hope of finding their vessel, with a perseverance which is characteristic of the fishermen, have been fortunate in shaping their course for land, and succeded, after a wearisome row of two or three hundred miles, exposed to constant dangers, and suffering for food, in reaching the shore in safety. Such instances, however, are rare. The majority of those who thus get estrayed from their vessel, pay the penalty with their lives; and it does not require a very vivid imagination to portray the sufferings these men must endure, adrift as they are in a dory, on the vast expanse of water, with death by starvation, or to be swallowed up by the waves, constantly staring them in the face, each hour rendering their hope of escape less encouraging, adding to their discomforts and decreasing their powers of endurance. Many a bold-hearted fisherman, with the love of life strong within him, with youth and hope and bright prospects, ere he left his ressel in those fog-benighted regions, has had all these hopes and aspirations suddenly quenched, upon finding himself either alone, as is sometimes the case, but most generally with one companion, adrift on the Banks, and nearly exhausted in their efforts to find the vessel, which to them is the ark of safety. 
To lessen these dangers, each dory should be provided with sumeient food and water to sustain lifo for several days; but the chanees even then are against the fishermen, and every year adds to tho list of those lost while cugaged in setting or picking their trawls.

The losses while engaged in trawl fishing as well as the cases of drowning from the vessels, are among the saddest incidents connected with the business, and the coming into the harbor of a vessel with her flag floating at half-mast, is an occasion of mournful interest. Jajies Davis, Esq., has expressed the feeling awakened by such occurrences in the following beautiful poem, which was originally published in the columns of the Cape $\Lambda$ nn Advertiser, and which we deem exceedingly appropriato to introduce into this chapter :-

\section{HALF-MAST HIGH.}

Inalf-mast high tho signal floats 1 She's coming in from sea,

Bome sallor of her crew is gone, Who may tholost one be?

The landsmen gaze as sho draws nigh, With trembllng, sad coneern, Tho reasel's namo to learn,

That comes with colors half-mast high.

IIalf-mast high tho signal flosts I

Who shall tho mourners bc,

That soon must weep sad tears for him They never more shall see?

Ab 1 many may heave the anxlous sigh, For fear that it may provo

To bo the one they love,

For whom tho lag floats lalf-mast high.
Inlf-mast bigh tho slgnal floats d Oh! ean at bo 'tis he?

It speaks relief to other hearts, But is a knell to me.

The word that names hlm who doth 10 Low in hls watery nrn, And never shall return;

For mine the flag floats half-inast high.

IIalf-mast high tho elgnal floats !

Thus bonored let them bc,

Who perish thus that wo may livo

On treasures of the sea.

For them, the hardy brave who die, And find no other grave

But the deep ocean wave,

We'll ralse the colors half-mast high.

If the hair-breadth escapes which every Georgesman or Banker has met with at one time or another could be gathered from the lips of those who encountered them and saw death so very near, - scarcely a hope of escape, - what a volume it would make, and how its perusal would thrill the heart of the reader! We could hardly believe these tales which the fishermen relate, unless they were authenticated by the most truthful circumstances, and the facts corroborated by their companions who were equally exposed to the threatening dangers, and with their shipmates stood face to face with death. Such tales are replete with the most thrilling inciclents, and in other chapters of this book we publish several such, almost verbatim, as received from the persons who passed through the dangers and returned to port, scarcely knowing bow they escaped, except as some of them solemnly 
affirmed, the good God lent his powerful aid in the midst of their dire extremity, and held them in the hollow of his mighty hand.

Notwithstanding the large number or men, from this town, who served in the army and navy during the rebellion, the loss of life from the casualties of war was far less than the losses at sea for the same period of time. There were two hundred and eighty-two lives lost in the fishing business from this port during the four years of the war, while the record of those who have been killed, or died in the service, is less than half that number. It thus appears that our town suffered more from the perils of the ocean than the ravages of war - a fact which would hardly be credited, did not the statistics prove it.

Ay, these perils attending the fisheries! These it is which cause the heart of the young maiden or wife to quake with fear every time her lover or husband leaves port ; these it is which disturb the slumbers of wife, sweetheart, mother and sister, which haunts them when they press their pillows at night, causing those fearful dreams of storm, shipwreck and disaster, which seem so much like reality that the dreamers start in their slumbers, feeling that awful dread which accompanies suspense, and which is so extremely difficult to banish from the mincl, even when one is convinced that these phantoms are merely the illusions of a dream.

The wearisome and anxious watching for the return of the vessel which never again comes back to port! That "looking out over the sea," with longing eyes, which is so often done by those having friends absent on the water, and which has been so well described by H. C. L. Haskell in one of his poems, which was also published in the Advertiser, and so appropriate, that we take the liberty to transfer it : -

\section{LOOKING OUT OVER THE SEA.}

HERE.

Looking out over the sea, From a granito rim of shore, Looklng out longingly, wearily, Over a turbulent, pitlless sea,

For the sails that come no more;

Waiting and watoblng with tear-wet eyes, Tili the last faint hope in the bosom dles;

Whlle the waves crawl up o'er the chill, white sand,

Those watchers long for a clasplng hand, And turn away with a thrill of paln,

But often pare to look agaln

From the rough, dark roeks of the sea-beat shore,

For the glcam of snowy bails onco more.

Badly, longingly, wearily,

Looklng out over the sea.
THERE.

Looking out over the sea, From the beautiful, golden strand, Looking out gladly, rejolcingly, Over the waves of a tranquil sea, From the shores of a summer land;

Waiting for comings that onec shall be, And then each voyager from earth set frce, Free from sorrow and care and pain, Shall leave the Haven never again. There they arc watchlng whose spirits fled And journeyed on to the Port ahead;

Happlly, gladly, rejolcingly,

Looking out over the sen. 
These perils have made of Georges a vast burial ground, where the bones of the fishermen are moved with the changing tide, or lie buried far beneatls the sands of her treacherous shoals. $\Lambda$ vast sepulchre, swallowing up many a young man in the pride of his youth, many a middle-aged toiler upon whose earnings a loving family were dependent, and many an aged one whose royage of life, at best, would not have continued but a few years longer. What a throng have thus heard the summons, and amid the shriek of the gale, the crashing of timbers, met the "boatman pale," and been transferred from the storms of mortal life safely into the calm and peacefulness of the immortal! The fearful record which follows this chapter tells its own story of woe and bereavement, and is published in this volume as a memorial of the brave men who thus went out from among us, and over whose resting-places no monumental stone can ever be placed as a tribute to their many virtues.

As their former comrades read the names of these lost fishermen, many pleasant recollections of the old days, when they sajled with them in some of the crafts, will be revived, and we doubt not that these recollections will cause the tears to course down many a weather-beaten face, as he softly repeats a prayer for peace to the souls of those who have thus entered the beyond. 


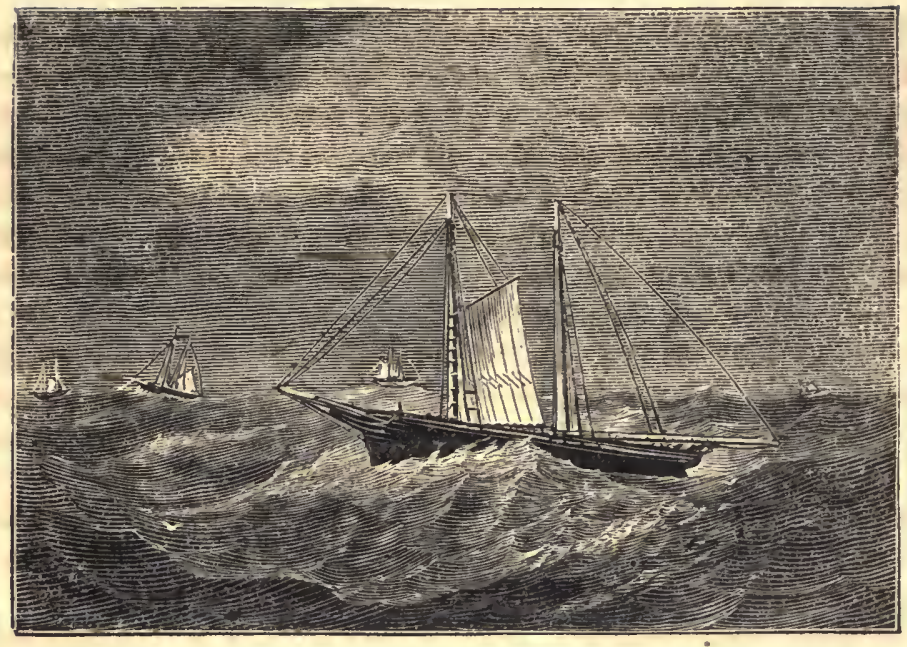

List of the Names of Twelve Hundred and Fifty-two Men and Two Hundred and Eighty-one Vessels Lost in the Fisheries and other Maritime Branches, from the Port of Gloucester, from the Year 1830, to July 1st, 1873, Embracing a Period of Nearly Half a Century. Also, the Taluation of the Vessel Propcrty, and Insurance thereon.

The following list of lives and vessels lost from this port commences with the year 1830, that being the period which marked the commencement of the Georges winter fishery, in the pursuit of which the great proportion of the losses have occurred. It has been found impossible to obtain the name of every one of thesc lost fishermen, as it has sometimes occurred that men have been shipped just as the ressel was about sailing, and in the hurry of the moment their names were not added to the crew list. Consequently the reader will occasionally read the sad word, unknown. We have used every effort within our power to obtain the names of the unknown, as we wished, if possible, to have the record complete; but were compelled to give up further inquiry, as there was not the slightest possibility of gaining the required information. We are pleased to state that in these latter years the fishing firms are much more particular in obtaining correct crew lists of their vessels, ere they sail on their trips, and it is to be hoped that in the future this will be attencled to in every instance. 
1830.

There were three vessels lost from the fleet this year in the mackerel fishery, with seven men.

Schooner OLIVE was lost in the month of August, with sevel: men, as follows: Samuel Jowle, Master; James Millett, Richard Dexter, Stephen Adans, William Adams, James Tueker, George Emmons. Owned by Messrs. Brown, Woodbury \& Co. Valued at $\$ 1,600$, and insured.

Sehooner HERALD went ashore on Eastern Point, October 20th, and became a total loss. Crew saved. Owned by William Parsons, Jr., and others, and unirsured.

Schooner AMAZON, lost in the Bay of Chaleur. Crew saved. Owned by Daniel Gaffney. Valued at $\$ 2,000$; insured for $\$ 1,500$.

\section{2.}

Schooner FRIENDSHIP, Capt. Kenney, lost off Cape Sable. Crew saved. Owned by James Mansficld \& Sons.

1833.

Schooner AMERICA, wrecked on George's Island, Boston Harbor, $\Lambda$ pril 23d. Crew saved.

1834.

- Schooner ESSEX, freighter, Capt. Underwood, was lost, with her crew of four men, on the passage from New York to Port Cabello. Valued at $\$ 1,500$; no insurance.

1836.

Schooner GOVERNOR EUSTIS, lost on Rainsford Island, Boston Harbor, Feb. 17th. Crew sared.

\section{7.}

During the month of April a severe gale swept orer Georges, where the fleet were engaged in fishing. Three of their number, with their crews, comprising about twenty-four men, sank beueath the billows. This was the first serious loss on Georges of which we bave the particulars, and those who remember the event, inform us that it spread a deep gloom over the town, and the widors and fattherless children had the heartfelt sympathies of the entire community. These vessels were as follows :

Schooner FAIR AMERICA, John Wonsow, Master, and six oth- 
ers, viz.: Jabez Wonson, the master's brother, William Prindall, - Andrews, - Stapleton, —_ Trask, _ Andrews. She was owned by William Parkhurst, and valued at $\$ 1,600$, and uninsured.

Schooner BENJAMIN FRANKLIN, Benjamin P. Norwood, Master, and six others, viz.: William Hinckley, Abraham Tarr, Jr., William S. Lane, Fitz Norwood, John R. Mitchell, Meshach Lane. Owned by Samuel W. Brown. Valued at $\$ 4,000$; insured for $\$ 3,300$.

Schooner VESTA, Josiah H. Fears, Master, and crew of six men, viz.: George Goodrich, Edward Prindall, David Butler, William Mason, Edward Bell, and one other whose name we could not learn. Valued at $\$ 2,000$; insured for $\$ 1,000$.

Schooner RISING EMPIRE, Capt. Lane, was run down and sunk while mackereling, July 14th. Crew saved. Owned by Messrs. Daniel and Michael Gaffney. Valued at $\$ 1,000$; uninsured.

Schooner ADRIAN, lost on St. John's Island, August 10th. Crew saved. Valued at $\$ 1,500$.

1838.

There were four vessels lost this year, and four men, as follows:

Schooner MARTHA, a new vessel coming around from Essex, was capsized off Brace's Cove in a violent squall. Adoniram Boyd, her owner, and Obed Pulcifer, with two others, whose names we could not ascertaln, were lost. Valued at $\$ 2,000$; uninsured.

Schooner GENTILE, Gorham Riggs, Master; lost on Margaree Island, Bay of St. Lawrence, October 29th. Crew saved. Valued at $\$ 3,000$; insurance of $\$ 2,000$. Owned by the master and others.

Schooner MONTICELLO, Burnham, Master; lost in the mackerel fishery. Crew saved. Owned by Richard Friend \& Sons. Valued at $\$ 1,500$; insured for $\$ 1,000$.

Schooner MAID OF THE MILL, lost off the coast of Maine. Crew saved. Owned by Tristram Griffin. Valued at $\$ 600$; unin sured.

\section{9.}

Two vessels and four lives were lost this year, as follows:

Schooner SEVO was run down in the night, by steamer Huntress, off Thacher's Island, and sank almost immediately. Capt. Peletiah Barker, Jr., of Portland, succeeded in climbing on board the steamer. Winthrop Sargent, a lad of twelve years, crawled out to the end of the bowsprit, and as the vessel was going down, grasped a splitting table which floated by, and by his cries attracted the attention of those on board the steamer, who rescued him with much difficulty. 
The steamer pursued her course, and the sails of the vesscl drifting ashore near Brace's Cove, it was thought all hands were lost. On the return trip of the steamer, young Sargent was brought home, and at two o'clock in the morning, was landed at Eastern Point, and, lad though he was, commenced his lonely journey of walking to town. He reached his father's house at about four o'clock, and knowing that he slept in a bed-room on the lower floor, tapped on the window. His father immediately awoke and exclaimed, "Who is there?" "It's your boy Winthrop," was the reply. Mr. Sargent at first thought it must be the ghost of the lad, as he had given him up as drowned; but young Winthrop had no idea of being taken for a ghost, and soon gave evidence that he was alive and well, which caused great rejoicing in the family. Thero were four men lost in this vessel, viz.: Richard Triton, Nathaniel Remby, Jonathan Osgood, James McDonald. Owned by Messrs. Ellery \& Gaffney. Valued at $\$ 1,300$; insured for $\$ 1,150$.

Schooner TRANSPOR'T, Poole, Master, was capsized December 28th. Crew saved. Valued at $\$ 2,500$; insured for $\$ 2,000$.

\section{0.}

Two vessels and six lives were lost this year, as follows:

Schooner IDA, was lost on Georges in the month of March. Had six men, viz.: Job Rowe, Master; Albert Oakes, Francis Colbach, Samuel Lloyd, Joshna Clark, Andrew Johnson. Valued at $\$ 1,800$; uninsured.

Schooner MARY \& ELIZABETH, Capt. Friend; lost at St. Peters, Bay of St. Lawrence, in Octobel. Crew saved. Valued at $\$ 2,000$; insured for $\$ 1,400$.

\section{1.}

There were two vessels and eight lives lost this year, as follows:

Schooner FOREST, mackereling, was lost on Cape Cod, Oct. 4th, with eight men: Steplen Rich, Master; Robert S. Sawyer, Asa L. Collins, Benjamin Robinson, Joseph Gerring, Francis Williams, John Quincy Adams, Abraham Ober. Owned by the master and Messrs. Giles \& Wonson. Valued at $\$ 2,500$, and uninsured.

Boat 'JACK DOWNING, lost at Annisquam. Crew saved. Owned by Daniel Robinson. Valued at $\$ 225$; insured for $\$ 150$.

\section{2.}

Three vessels were lost this year, viz. :

Schooner REINDEER, mackereling, lost in Newport Harbor, June 
13th. Crew saved. Owned by James Mansfield \& Sons. Valued at $\$ 1,000$, and uninsured.

Schooner LIVELY, shore cod fishery, lost on Cape Cod in May. Crew saved. Owned by Joseph Friend \& Co. Valued at $\$ 800$; uninsured.

Schooner MIL'O, lost on Isle of Shoals, November 15̆th. Crew saved. Valued at $\$ 200$; insured for $\$ 150$.

\section{3.}

There were three vessels and ten lives lost this year in the mackerel fishery, as follows :

Schooner BYRON, George Watson, Master; was in the mackerel fishery, and was lost in the South Channel in the month of August. The following is a part of her crew list: Benjarnin Watson, brother to the master; John R. Curtis, Hosea Nelson, Aaron Perkins, Frederick Parsons, Isaac Fears, Joseph Fears, Jr., Joseph Stevens. Owned by Messrs. Joseph Friend \& Co. Valued at $\$ 3,500$; uninsured.

Schooner HENRIETTA, lost in the Bay of St. Lawrence in September. Crew saved. Owned by Gaffuey \& Davis. Valued at $\$ 1,000$; insured for $\$ 800$.

Schooner BRANCH, also lost in Bay of St. Lawrence. Crew saved. Owned by Richard Friend \& Sons. Valued at $\$ 1,500$; insured for $\$ 1,200$.

\section{4.}

There were three vessels and seven lives lost this year, viz.:

Schooner CONFIDENCE, lost on Georges in the month of Feb- ruary (the 28 th, it is suposed). Had seven men on board, as follows : David Parsons, Master; Epes Norwood, Epes Norwood, Jr., Israel M. Wonson, Samuel Martin, Jeffrey Parsons, Moses Hodgkins. Owned by John Wonson, East Gloucester. Valued at $\$ 1,500$, and uninsured.

Schooner ABIGAIL \& ELIZA, Charles Sutton, Master, lost in the coasting business at St. Thomas. Crew saved. Valued at $\$ 3,000$; insured for $\$ 1,500$.

Boat FAWN, lost on Rocky Neck in December.

\section{5 .}

There were four vessels and seven lives lost this year, as follows:

Schooner PARIS, lost on Georges in March, with eight men. Hugh Parkhurst, Master; Fitz E. Oakes, Moses Parsons, 4th, Sim- 
eon Comn, James Low, Jacob Knnights, Daniel Davis, Joln Wonson, Jr. Owned by the master and William Parkhurst \& Bro. Valued at $\$ 1,600$; insured for $\$ 800$.

Schooner REFORM, lost on Sandy Hook, May 15th. Crew saved. Owned by Samuel W. Brown. Valued at $\$ 900$; insured for $\$ 750$.

Sehooner ONLY DAUGHTER, was run clown and sunk off Cape Canso, July 18th. Crew saved.

Sehooner EAGLE, Levi Robinson, Master; lost near Wood Island, November 7th. Crew saved. Owned by George N. Davis. Valued at $\$ 1,000$; insured for $\$ 800$.

\section{6.}

There were three vessels and fifteen lives lost this year, as follows: Schooner GENERAL SCOTT, lost on Georges in November. James Bowdoin, Master, and a crew of seven men: Anthony Wise, Noalı Quiner, Seth Foster, John Hawley, Joseph Gerring, Benjamin Millett, George Millett. Orned by David Parkhurst. Valued at $\$ 2,400$; insured for $\$ 1,600$.

Schooner CANTON, lost on Georges in November. Had seven men, as follows: James Norwood, Jr., Master; John Saunders, Jr., Elisha Lufkin, Samuel Parsons, Ephraim Tibbetts, Isaac Poole, John Woodbury. Owned by Samuel W. Brown. Valued at $\$ 1,500$; insured for $\$ 1,200$.

Schooner FRANCES ELIZABETH, lost near Sparling's Point, Me., November $25 \mathrm{th}$. Crew saved. Valued at $\$ 1,000$; insured for $\$ 800$.

\section{7.}

There were three ressels lost this year, but fortunately no lives.

Schooner DELEGATE, Montgomery, Master; sunk on Georges, April 29th. Crew saved by schooner Talisman. Owned by Epes Sayward \& Co. Valued at $\$ 1,500$; insured for $\$ 1,100$.

Schooner RIO GRANDE, cod fishing, lost on Eastern Point, June 11th. Crew saved. Owned by Addison Gilbert, George Garland, and others. Valued at $\$ 3,500$; insured for $\$ 3,200$.

Schooner BALANCE, Francis Bennett, Master; in the freighting business, lost near Cape May, January 23d. Crew saved. Valued at $\$ 1,200$; one-eighth insured for $\$ 150$. Owned by the master, and others.

\section{9.}

There were two vessels and ten lives lost this year, as follows: Schooner LEVI WOODBURY, lost in October, near Boon Island. 
Engaged in the shore mackerel fishery. Had ten men on board. William Fears, Master; Josiah Bradstreet, Jr., John J. Parsons, Joseph W. Babson, Augustus Burnham, Theodore Andrews, Benjamin H. Glover, Charles Ward, Thomas Roberts, Thomas Lane. Orned by the master and Robert Fears. Valued at $\$ 2,500$; insured for $\$ 2,000$.

Schooner ENCHANTRESS, Enoch Snow, Master, lost on Cape Sable, June 4th. Crew saverl. Owned by Joseph O. Procter. Valued at $\$ 1,000$; one quarter insured for $\$ 200$.

1850.

This proved a most disastrons year to the Georges fishery, resulting in the loss of four vessels and thirty-nine lives, as follows:

Schooner WILLIAM WALLACE, lost in February, with eight men: Stephen Decatur Griffin, of Annisquam, Master; Daniel Adams, George Brown, 3d, Frederick A. Lewis, William Grant, Joln Linedall, William Mansfield, Thomas Ingalls. Owned by Fitz E. Riggs \& Bro. Valued at $\$ 3,000$; insured for $\$ 2,600$.

Schooner TUSCANY, lost in March, with eight men. Charles H. Pew, Master; James Shackleford, John J. Barrett, Rufus Parsons, Aaron Hodgkins, Nathaniel S. Lufkin, Benjamin H. Brown, Jr., Spencer T. Jackson. Owned by the master and John Pew. Valued at $\$ 3,500$; insured for $\$ 2,800$.

Schooner WALTER SCOTT, lost in April, with eight men. Jas. Hibbert, Master; Noah Hibbert, William Dexter, Israel Dodge, William A. Gahan, Thomas Wilson, Mark Lewis, Charles Gahan. Owned by James Hibbert and George Parkhurst. Valued at $\$ 3,000$; insured for $\$ 2,400$.

Schooner SPECIE, lost the same month, with seven men. Benjamin Tarr, Master; Charles Witham, Jr., Charles Lufkin, Augustus Anderson, Peter Anderson, Lewis Rice, Charles Tarr. Owned by David Parkhurst. Valued at $\$ 3,000$; insured for $\$ 2,500$.

\section{1.}

Another disastrous year to the Gloucester fishing fleet, resulting in the loss of nine vessels and thirty-two lives, all in the mackerel fishery, but one, and she was on Georges.

Schooner OCEAN QUEEN was lost on Georges the 27th of November. There were eight men on board, as follows : Josiah Spinney, Master; George Horn, George Wolf, Stephen Snyder, William G. Nickerson, Thomas Henderson, Edward Armstrong, Amos Stuart. 
Owned by George Friend \& Co. Valued at $\$ 3,000$; insured for $\$ 2,500$.

Schooner FLIR'T sank at her auchors in the Bay of St. Lawrence, during the terrible gale of October $3 \mathrm{~d}$. Had fourteen men on board. Aaron Stubbs, Master; Joseph Clıandler, John Stubbs, Hugh Harnden, Elward Monsen, William Dauphney, George Fenley, Stephen Nickerson, William Forbes, Dean W. Woodbury, James Smith, John Shaw, and two others whose names are unknown. Owned by the master and Samnel Wonson \& Sons. Valued at $\$ 4,000$; insured for $\$ 3,500$.

Schooner PRINCETON, lost in the Bay of St. Lawrence, in October. Had ten mell, viz. : 'Thomas Guard, Master ; Charles Wonson, Jr., John Gerring, Jr., Peter Shean, William W. Shean, Solomon Mehlman, Amold Mason, Warren Pinkham, John Morrissey, Wm. Duffey. Owned by Benjamin Parsons \& Sons. Valued at $\$ 3,000$; insured for $\$ 2,600$.

Schooner JUBILEE, run down in Bay of St. Lawrence, by schooner Summit. Crew saved. Owned by Daniel B. Hodgkins. Valued at $\$ 900$; insured for $\$ 800$.

Schooner DANIEL P. KINGG, Harty, Master' ; lost at Cape Breton, October 12th. Crew saved. Owned by Moses Tarr. Valned at $\$ 3,600$; insured for $\$ 3,000$.

Schooner REDWING, lost at Chetticamp, October 12th. Crew saved. Owned by James Mansfield \& Sons. Valued at $\$ 1,400$; insured for $\$ 1,200$.

Schooner GARLAND, James McIntire, Master; lost at Malpec, in October. Crew saved. Owned by the master and Messrs. Garland \& Cunningham, of Baltimore. Valued $\$ 4,000$; insured for $\$ 3,500$.

Schooner POWHATTEN, lost in the Bay of St. Lawrence, in October. Crew saved. Owned at Annisquam. Valued at $\$ 1,500$; insured for $\$ 1,200$.

Schooner ELEANOR, lost at Malpec, in October. Crew saved. Owned by Robert Fears and others. Valued at $\$ 4,000$; insured-for $\$ 3,500$.

\section{2.}

This proved a still more disastrous year for the fishing business; thirteen ressels and thirty-two lives being lost. Five of these ressels were lost on Georges, and eight in the Bay of St. Lawrence, as follows : 
Schooner GOLDEN FLEECE, lost on Georges, in March, nine men: Sylvester Rust, Master; Samuel Rust, brother of the master; Edmund Cook, James S. Norwood, Henry Robinson, Samuel Jackman, George Blaisdell, Samuel Atwood, and one man name unknown. Owned by W. H. Steele and Daniel Gaffney. Valued at $\$ 4,000$; insured for $\$ 3,500$.

Schooner C. E. PARKHURST, lost on Georges in March. She had a crew of eight men, viz.: John B. Turner, Master; William Dexter, Henry Holley, Philip Pico, John King, John Colney, William Riddel, John Nelson. Owned by.Charles Parkhurst. Valued at $\$ 4,000$; insured for $\$ 3,500$.

Schooner BENJAMIIN PARSONS, lost on Georges in April. Seven men, as follows: William Tibbets, Master; William G. Palmer, Charles J. Gilbert, John Guiro, David Aspee, James Mars, Dennis Phenelon. Owned by William Parsons, 2d, \& Co. Valued at $\$ 4,000$; insured for $\$ 3,500$.

Schooner NAPOLEON, lost on Georges in the same gale. Had a crew of eight men, viz.: Addison Parsons, Master; William Dunmore, Benjamin Rowe, Edward Everly, Frank McCloud; Antone Cora, John Poland, and one man name unknown. Owned by Moses 'Tarr.' Valued at $\$ 1,600$; insured for $\$ 1,400$.

Schooner HENRY A. HOLBROOK, lost on Georges in November. Crew eight in number: William Remby, Master; Obed A. Andrews, James Reed, Henry Green, John MeKinnon, William Potton, Osborne S. Lawrence, William Hayden. Owned by George Friend \& Co. Valued at $\$ 2,600$; insured for $\$ 2,300$.

Schooner CYRENA S. COLBY, Colby, Master; lost at Cascumpec, in September. Crew saved. Owned by Addison Merchant \& Co., and others. Valued at $\$ 5,000$; insured for $\$ 4,700$.

Schooner JOHN GERARD, lost in the Bay of St. Lawrence, in October. Crew saved. Owned by Joln F. Wonson \& Co. Valued at $\$ 4,000$; insured for $\$ 3,500$.

Schooner ATLANTA, lost at Souris, Bay of St. Lawrence, Oetober 15th. Crew saver. Owned by George Friend \& Co. Valued at $\$ 3,400$; insured for $\$ 3,000$.

Schooner OCEAN STAR, lost at Souris, October 15th. Crew saved. Owned by George Garland and Theodore Parsons. Valued at $\$ 4,000$; insured for $\$ 3,500$.

Schooner HANNIBAL, lost at Souris, October 15th. Crew saved. Owned by E. \& Epes W. Merchant \& Co. Valued at $\$ 2,600$; insured for $\$ 2,200$. 
Schooner AUGUSTA PARKER, lost at Souris in the same gale. Crew saved. Owned by Epes W. Mereliant, and others. Valued at $\$ 2,800$; insured for $\$ 2,400$.

Schooner RIO DlEL NORTE, lost at Souris, Oetober 15th. Crew saved. Orned by Messrs. Moses 'Tarr and Andrew Leighton. Valued at $\$ 2,800$ : insured for $\$ 2,400$.

Schooner LEADER, lost at Souris, Octoher 15th. Crew saved. Owned by Messrs. James Mansfield \& Sons. Valued at $\$ 1,000$; insured for $\$ 800$.

1853.

Three vessels were lost this year, one in the Bay of St. Lawrence, and two in the shore fishery, as follows:

Schooner CHAMIION, Webb, Master; lost in the Bay of St. Lawrence, in October. Crew saved. Owned by James Mansfield \& Sons and others. Valued at $\$ 1,800$; insured for $\$ 1,500$.

Schooner OCEAN NYMPI, Capt. Samucl Elwell, Jr., run ciown by ship Saral Jane, off Cape Cod, May 2ג. Crew saved. Owned by master and others. Valued at $\$ 4,000$; insured for $\$ 3,500$.

Schoower MIARY A. TAYLOR, Benjamin Taylor, Master; cod fishery, lost in Chatham IIarbor, April 19tl. Owned by Messrs. Grover \& Steele. Valued at $\$ 4,200$; insured for $\$ 3,800$.

\section{4.}

There were four vessels and twenty-six lives lost this year. Two vessels and twenty-one lives were lost on Georges, and two vessels in the traling business, viz. :

Schooner FLIGHT, lost on Georges, in February. She had a crew of twelve men, as follows: Elias H. Willis, Master; Mark Webber, Joln Littlefield, Charles Stearns, Thomas Frederickson, Frank McKenney, Thomas Furguson, Richard McCrate, and four men, uames unknown. Owned by E. W. Merehant, and others. Valued at $\$ 4,000$; insured for $\$ 3,500$.

Schooner LUCY PULCIFER, lost on Georges, in March, with nine men, viz.: Peter MIcDonald, Master; Ronald MIcDonald, John May, Jobn Myers, Spencer A. Tyron, George MeIntire, George Brooks, Charles Hardison, Thomas Murphy. Owned by David Parkhurst, and others. Valued at $\$ 3,600$; insured for $\$ 3,150$.

Sehooner GOLD IIUNTER, in the coasting trade, sailed for Virginia on the night of February 17th, and was never afterward heard fiom. She had a crew of fire men, viz.: Timothy McIntire, Mas- 
ter; Murdoch MeLane, Mate; Sylvester LeBarron, Samuel Miller, Charles H. Rowe. Owned by the master and others. Valued at $\$ 4,500$; insured for $\$ 4,000$.

Schooner SLSAN, in the coasting trade, lost December 1st, near Old House Cove, in this harbor. Crew saved. Owned by Moses Tarr. Valued at $\$ 2,500$; insured for $\$ 2,000$.

\section{5.}

Seren vessels and twenty-one lives were lost this year, viz.: Two vessels and sixteen lives on Georges; two vessels and five lives in the eoasting trade; one schooner in Bay mackerel fishing, and two in the shore fishery, as follows:

Schooner REPORTER, lost on Georges, in March. She had a crew of eight men, viz.: Joln Bearse, Master; Samuel Bearse, Edward Stuart, Joseph Sexton, James Rich, Nicholas Gifford, Charles Wooden, Michael Clary. Owned by Joseph O. Procter, and others. Valued at $\$ 4,500$; insured for $\$ 3,500$.

Schooner ABNER L. COLBY, lost on Georges, in March, eight men: James Brown, Master; John J. Hutt, Was. McCaleb, John Pyne, James Sullivan, James MIarr, James Flarhety, John Powers. Owned by Addison Merchant \& Co. Valued at $\$ 4,000$; insured for $\$ 3,500$.

Schooner BESSIE NEAL, in the trading business, lost on the passage from Prince Edward's Island to this port. Had a crew of five men, viz.: Joseph Herrick, Jr., Master; John MeDonald, Mate; Duncan Hay, Isaac Hyde, James Roderick. Owned by C. E. \& E. Grover, and others. Valued at $\$ 5,000$; insured for $\$ 3,000$.

Schooner MARY JONES, Friend, Master; mackereling, lost on Prince Edward's Island, in September. Crew saved. Owned by George Friend, Jr., and others. Valned at \$2,500; insured for $\$ 2,200$.

Schooner SOMERVILLE, George Adams, MIaster; bound for Wilmington, N. C., sunk July 18th. Crew saved. Owned by David Babson, and others, and insured.

Schooner PHILANTHROPIST, Tristram Griffin, Master; lost at mouth of Aunisquam Harbor, December 24th. Crew saved. Owned by master. Valued at $\$ 1,500$; insured for $\$ 1,200$.

Schooner VAN, lost on Folly Island, Me. Crew saved. Owned by Daniel Robinsou. Valued at $\$ 1,400$; insured for $\$ 1,200$.

1856.

Five schooners were lost in the Bay of St. Lawrence, this year, and one vessel and two lives off this shore, as follows: 
Schooner ALPHA, lost in the Gut of Canso. Crew saved. Owned by Moses Burnhan, and others. Valued at $\$ 700$; insured for $\$ 500$.

Schooner LIONESS, Nathaniel Watson, Master; burnt at Cambelton, Bay Chaleur, June 30th. Partially insured.

Schoonel ITASIRA, lost in the Bay of St. Lawrence, in October. Crew saved. Owned by Samuel Irwin, and others. Valued at $\$ 3,800$; insured for $\$ 3,325$.

Schooner SAMUEL JONES, lost in the Bay of St. Lawrence. Crew saved. Owned by Charles Friend \& Co. Valned at $\$ 3,800$; insured for $\$ 3,325$.

Schooner ARBU'TUS, lost in the Bay of St. Lawrence, in October. Crew saved. Owned by Joseph O. Procter. Valıed at $\$ 3,800$; insured for $\$ 3,325$.

Boat KOSSUTH, was probably run down during the latter part of August, as she was never heard from after leaving port. Two men lost, Aaron Babcock and Daniel Marshall.

\section{7.}

Five vessels and nine men were lost this year, one on Georges, three in the Bay mackerel fishing, and one in the consting trade, viz. :

Schooner OOLONG, lost on Georges, in February. She had a crew of nine men, as follows: James M. Kendall, Master; George Juliar, Daniel Sullivan, Thomas A. Sinclair, James Hunter, Jolnn Williams, William Olson, Jolın Anderson, Jolnn Graham. Owned by Aaron D. Wells, and others. Valued at $\$ 4,000$; insured for $\$ 2,000$.

Schooner HOSEA BALLOU, lost in the Bay of St. Lawrence, in October. Crew saved. Owned by John Parker. Valued at $\$ 1,200$. insured for $\$ 1,050$.

Schooner MARY HAR'T, lost at Cape Breton, in October. Crew saved. Owned by James S. Ayer, and others. Valued at $\$ 3,000$; insured for $\$ 2,700$.

Schooner MONTEZUMA, lost at Cape Breton, in October. Owned by Andrew Leighton. Valued at $\$ 2,300$; insured for $\$ 2,000$.

Schooner PRISCILLA, in the trading business, lost on Norman's Woe, Gloucester Harbor, in July. Owned by James Mansifeld \& Sons. Valued at $\$ 1,000$, and uninsured.

1858.

There rere seven vessels and forty-two lives lost this year, as 
follows: four in the Bay of St. Lawrence, one in the P. E. Island trading; and two in the Newfoundland herring fishery.

Schooner VILLAGE BELIE, Angus Harvey, Master; with a crew of twelve men, whose names we were unable to obtain, as they were shipped in the Gut of Canso. The captain's wife and child, and a young lady passenger, were also on board, making in all sixteen lives lost in this vessel. Lost while coming from the Bay, in October. Owned by George F. Wonson \& Brother. Valued at $\$ 3,700$; insured for $\$ 3,237$.

Schooner THREE SISTERS, lost in the Bay of St. Lawrence, in November. Crew saved. Owned by Addison Merchant, and others. Valued at $\$ 500$; insured for $\$ 400$

Schooner PREMIUM, lost in the Bay of St. Lawrence, in October. Crew saved. Owned by David Low \& Co. Valued at $\$ 800$; insured for $\$ 700$

Scloonur GERANIUM, lost in the Bay of St. Lawrence, in October. Crew saved. Owned by Joseph O. Procter. Valued at $\$ 800$; insured for $\$ 700$.

Schooner JOHN FRANKLIN, was lost while coming from Prince Edward Island, in the winter of 1858-59. Had several passengers on board, and it is supposed fourteen persons went down in this vessel. Her crew list was as follows : John MIcDonald, Master; Dennis Murphy, Mate; John Cogle, Neil McNeil, Angus Chisholm, Edward Malady. The family of Cogle were among the passengers. Valued at $\$ 4,500$, and uninsured.

Schooner ALEXANDRIA sailed from Newfoundland for New York, Feb. 2d, with a cargo of herring, and was never afterwards heard from. She had a crew of six men, as follows: Samuel $\Lambda$. Miller, Master; Samuel S. Taylor, Mate; William G. Taylor, William E. Stevens, James Stevens, Zenas Doane. Owned by Dolliver \& Stacy. Valued at $\$ 4,000$, and uninsured.

Schooner QUEEN OF CLIPPERS, in the Newfoundland herring fishery, was lost with six men in the winter of 1858-59. George Stoddard, Master; Daniel Grant, Mate; William Powell, Huglı Cameron, Alex. Cameron, Thomas Donny. Owned by Andrew Leighton. Valued at $\$ 4,400$; insured for $\$ 3,500$.

1859.

There were six vessels and thirty-six lives lost this year, as follows: three on Georges, two in the Newfoundland fishery, and one freighter 
Schooner YOUNG AMERICA, lost on Georges, in March, with eight men. Clarles Lord, Master; Sewall H. Merrifield, William B. Haskins, William Grmage, Jason Davis, Joln Thurston, Nathaniel Larelett, Jolın A. Martin, mostly belonging in Roekport. Owned by Darid Low \& Co. Valued at $\$ 4,000$; insured for $\$ 3,500$.

Schooner GRACE T. POIVERS, lost on Georges, in the terrible

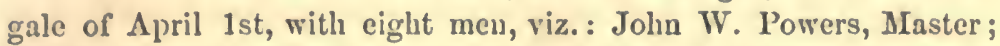
Stephen Powers, brother of the master; John T. Stutton, Benjamin Munroe, George Potter, Eleazer G. Noble, David Murray, James Lucas. Valued at $\$ 4,000$; insured for $\$ 3,500$.

Schooner CHARLES E. GROVER was probably lost the same day, with nine men, viz.: William Gould, Master; Thomas Walen, Elisha IIall, Stillman IIipson, Thomas Rolles, James Gray, James Parrington, Andrew Ness, Dexter Hall. Owned by George Friend \& Co. Valued at $\$ 3,400$; insured for $\$ 2,975$.

Schooner ETHERLINDE, Capt. Dix, in the Newfoundland fishery, lost on Ragged Island, in March. Crew saved. Owned by David Parkhurst, and the master. Valued at $\$ 4,500$; insured for $\$ 3,000$.

Schooner FENRIETTA, in the Newfoundland herring fishery, lost on Miquelon Island, in January. Crew saved. Owned by James S. Ayer. Valued at $\$ 4,000$; insured for $\$ 3,500$.

Schooner START, in the freighting business, lost on Narragansett Beach, Feb. 26th. Crew saved. Owned by John W. Lowe.

Asa West, of Belfast, Mc., was lost overboard, on the night of March 1st, from schooner Occan Ranger, on Georges.

George Grax, of Boston, was lost overboard from schooner Grapeshot, in the same galc.

Wrlliam Thompson, alias Thomas Shiel Lacount, of Mt. Desert, MIe, was lost from schooner Litile Lizzic, in the same gale.

Axdrew Fleesan, one of the crew of schooner Lilly Dale, was lost overboard off Mt. Desert, $\Lambda$ pril 1 st.

Alexander Frazier, of Cape Breton, N. S., of schooner Rorer, was lost on Georges, April 5th.

James MCDonald, one of the crew of schooner Christie Campbell, died in the Bay, from the effects of swallowing a match.

Peter Willianson, one of the crew of schooner St. Louis, fell overboard in Octover, while the vessel was in the Bay, and was drowned.

Caleb Goodwin, one of the crew of schooner Nourmahal, clied on Georges, quite suddenly, of heart disense, April 10 th. 
Daxiel S. Holly, one of the crew of schooner Sabine, was lnocked overboard by the boom, while the vessel was jibbing over in the Bay of St. Lawrence, September 2d, and was drowned.

Franklin Ameruran was knocked overboard by the main boom of schooner Flora Temple, in the Bay of St. Lawrence, Sept. 14th, and drowned.

Daniel H. Brown, of schooner Montebello, was knocked overboard and drowned off Cape Sable, October 6th, while on the passage home from the Bay.

\section{0 .}

The Georges fishery was quite disastrons this year, there having been five vessels and forty-eight lives lost in its pursuit; one vessel was lost in the mackerel fishery, with eleven men; thirteen men were lost from vessels other than Georgesmen, making a total of seventythree lives. One vessel was lost in the Prince Edward Island trade.

Schooner GEORGE WASHINGTON was lost in the February gale, with nine men: John McDonald, Master; John McGrath, John McPhee, Scwell King, Joseph Williams, Ronald McEacheron, Rora McPhee, Peter McNeil, Joseph King. Owned by Pettingill \& Cunningham. Valued at $\$ 4,000$; insured for $\$ 3,500$.

Schooner.ADVANCE was lost in the same gale with eight men, as follows : John Thompson, Master ; Benjamin F. Hamlin, Michael F. Morey, Edwin F. Hall, James Nolan, Charles Seymour, Joseph Sellers, Augustus McGrath, Thomas Nolan. Orned by William Parsons, $2 d$ \& Co. Valued at $\$ 3,650$; insured for $\$ 3,200$.

Schooner WILLIAM S. WONSON, lost in the same gale, with nine men, viz.: William II. Lunt, Master; Joseph W. Douglass, George Parsons, Gilbert Perry, Lawrence Cook, John Wilson, Wm. Carter, A. J. Knowlton, George Wainwright. Owned by George F. Wonson \& Brother. Valued at $\$ 4,500$; insured for $\$ 3,500$.

Schooner RELIEF, Elisha Newcombe, Master; with eight others, as follows: William Smith, Thomas Riley, Alex. McEacheron, Sam'l R. Spinney, Perez Butler, Charles Bearse, Jacob Vanamburg, Albert McIntire. Owned by John Pew \& Son. Valued at $\$ 3,800$; insured for $\$ 2,494$.

Schooner PLEASANT BAY was lost in April. Fitted by Messis. Pettingell \& Cunningham, and owned in Essex and Beverly. William II. Gage, Master. Of the crew of eight men, the name of Wm. Hodgkins, of this town, is the only one known; four of the others luailed from Beverly. - Valued at $\$ 3,800$; insured for $\$ 3,300$. 
Schooner NEITUNE'S BRIDE, lost on Malcomb's Ledge, Me., with eleven men, in the shore mackerel fishery. Jacob Olsen, Master; George Norwood, Mamuel Silva, J. Enos Silva, William Jolnnson, James II. Bird, Tolef Anderson, William Haley, J. Antoine Silva, Peter Johnson, nnd at young mun whose name could not be ascertained. Owned by Charles Parkhurst. Valued at $\$ 5,000$; insured for $\$ 3,500$. [JosErin MaIsI was taken fiom the mast-head in an a]most dying condition, and Hexur Jonssox clung to tho bont and was rescued.] See page 153 for the thrilling narrative of that fearful night.

Schooner PILOT, in the P. E. Island tracle, went ashore near ChabLam Camp, N. S., Dec. 20th, and became a total loss. No lives lost. Owned by H. Babson \& Co. Valued at $\$ 1,600$; insured for $\$ 1,000$.

Williasr Fowlen was lost overhoard from schooner Rattler, in the Bay of St. Lawrence, June 13th.

Hexny Hrll, of Winterport, Me., died on board schooner Romp, March 18th.

Fraxcis Wrasan and Gronge Granson, two of the crew of schooner Fearless, left their vessel on the Bank, March 30th, to set their trawls, and were never heard of afterwards.

Willins Potrer, of Providenee, fell between the wharf and vessel, at Charles Parkhurst's wharf, on the night of November 5th, and was so badly injured that he died.

Lost overboard, on her passage to Newfoundland, from schooner Sarah E. Smith, a man named Mrers.

Lost overboard, on Georges, from schooner Typhoon, Samuer P. Hese.

Lost overboard, from schooner Sarah B. Harris, Harnes Low, of Rockport.

Capt. Bexton Stony, of Rockport, was lost overboard from schooner We're Here, May 8th, off this harbor.

Wirlians F. Bowex, a lad of fifteen years, son of John D. Bowen, was lost overboard from schooner Rescue, Sept. 20th, on the passage from the Bay of St. Lawrence.

Onricin H. Wuxon was lost overboard from schooner John Pew, on the passage from the Bay, in September.

Cirantes F. Axdensox, of the schooner Traverse, was lost over. boarl in July, on Georges.

JoHx J. Allex, son of James D Alleu, was lost from schuoner Braut, Oct. Tth. 
Joseph PARsons was lost overboard from schooner S. E. Smith, in the Bay of St. Lawrence, Sept. 18th.

William Hart was lost from schooner Coquette, on the passage from the Bay of St. Lawrence, October 20th.

Capt. Joseph Greenleaf, was lost overboard from schooner Nile, on the passage from Boston, November 23d.

John Marstons was found drowned in the dock of the wharf of A. Merchant \& Co.

\section{1.}

The number of vessels lost this year is the largest of any one year thus far from this port, being fifteen. Number of lives, forty-four. There were four vessels lost on Georges, three in the Bay of St. Lawrence, three Georgesmen in the harbor, one on Cape Cod, one at St. Mary's, one at Ragged Island, one at Louisburg bar, and one at Cole Bay.

Schooner SWEEPS'TAKES, lost on Georges, in February. Jas. Scearth, Master' crew of eight men as follows: Neal Walker, Chas. Bixzett, Augustus McDonald, James Barkley, John Stewart, Matthew West, Thomas Jackman, James McCullough. Owned by Clark \& Rust. Valued at $\$ 4,000$; insured for $\$ 3,325$.

Schooner SUSAN YOUNG was lost the same time. Nine men. Anthony Medeors, Master; George McDonald, Otis R. Swain, Manuel Francis, Antoinc Gormez, Joseph Antoine, William Deunison, Edwin Nealy, Joseph Carter. Owned by Wm. H. Friend \& Co. Valued at $\$ 3,000$; insured for $\$ 2,275$.

Schooner H. M. STANWOOD was probably lost in the same gale. Patrick Gorman, Master ; and seven men : viz., Benjamin E. Owen, George Ash, James Warren, Joseph Minor, Henry Laroque, Joseph Parker, Gamaliel Stewart. Owned by Hardy \& McKenzie. Valued at $\$ 4,000$; insured for $\$ 3,500$.

Schooner WHITE SWALLOW lost at the same time, with nine men. Peter Nelson, Master; Charles H. Booman, Stephen Barnard, John Botherton, James McDonald, John Herman, John Jolınson, Peter Lawson, and Henry Bertram were lost in her. Orned by Davis \& Maddox. Valued at $\$ 3,400$; insured for $\$ 2,975$.

Schooner TELEGRAPH, while returning from Georges on the night of Feb. 16 th, came into collision with the schooner M. C. Rowe, off Eastern Point, and, becoming unmanageable, went ashore near Norman's Woe, and became a total loss. One of the crew, Emannel 
Ferdinand, was drowned; the remainder were saved. Owned by Charles Parklumst. Valued at $\$ 3,200$; insured for $\$ 2,800$.

Schooners MLARY D. BABSON and D. P. GALE drove out of the harbor in the severe gale of March 21 st, and went ashore near "Old Honse Cove," where they hecame a total loss. The former was owned by 11 . Babson \& Co., valued at $\$ 4,500$; insured for $\$ 3,775$, and the latter by David Parkhurst \& Co. Valued at $\$ 4,600$; insured for $\$ 4,000$. Crews savel.

Schooner MOHENIE, while returning from the Bay, in August, went ashore at Cape Sable, and became a total loss. Crew saved. Owned by David Parklurst \& Co. Valued at $\$ 3,450$; insured for $\$ 3,150$.

Schooner COQUETTE went ashore on the bar at Port Hood, in September, and became a total wreck. Crew savecl. Owned by George F. Wonson and Bros. Valued at $\$ 3,200$; insured for $\$ 2,800$.

Schooner E. K. KANE went ashore at Liverpool, N. S., on her return trip from the Bay, and became a total loss. Crew saved. Owned by Pettingill \& Cunningham. Valued at $\$ 3,400$; insured for $\$ 2,800$.

Schooner REPUBLIC, while returning from a tracling voyage, went ashore at Ragged Island, and became a total loss. Crew saved. Owned by Charles Friend \& Co. Valued at $\$ 2,500$; insured for $\$ 2,000$.

Schooner NARRAGAUGUS, from St. Pierre, Miquelon, went ashore at St. Mary's, near Guy'sboro', Feb. 12th, and was lost. Crew saved. Owned by George Hughes.

Schooner R. H. OAKES went ashore on Louisburg Bar, December 24th, and became a total loss. Crew saved. Owned by Sinclair \& Low. Valued at $\$ 6,000$; insured for $\$ 5,000$.

Schooner ELLA OSBORNE went ashore at Cole Bay, in December, and became a totill loss. Crew saved. Owned by Capt. Jolun IIcMullen. Valned at $\$ 3,200$; insured for $\$ 2,500$.

Schooner ST. CLOUD, lost in March, on Cape Corl, while on a voyage from New York to Boston. Crew saved. Owned by George Steele. Valued at $\$ 3,800$; insured for $\$ 3,000$.

Frank Williams was lost overboard from schooner Daniel MePhee, on a trip to Western Banks, in February.

JonN Witmas was lost about twenty-five uniles off Eastern Point, from schooner Sparkling Wave, on a return trip from Georges, in March. 
William L. Elmore was lost on Georges, in March, from schooner Rival.

Alfred Adans, lost overboard in March, from schooner Lucille Curtis, on Georges.

James Clarex was lost from schooner General Butler, in the Gut of Canso.

Joseph Shankling, lost in the Bay from schooner Lodi, in November.

Duncan MoMullen and Willyam French, left schooner Cynisca on the Banks, October 12th, to examine their tratwls, and were never seen again.

\section{2.}

LOST IN TIIE FEBRUARY GALE.

On Monday evening, February 24th, a terrible gale from the northwest suddenly burst upon the fishing fleet on Georges, where there were about seventy sail at anchor very near to each other. Not having sufficient warning of the blow, they were unable to heave up, ard the fact of there being thirteen ressels lost with their entire crews, and two abandoned, and their crews rescued by inward-bound vessels, will give some idea of the fearful collisions which occurred, and the terrible violence of the storm. The anxiety of those having friends thus exposed was terrible to witness, and, as each vessel rounded Eastern Point, there was the most intense desire to learn her name, and to ascertain if those on board had seen anything of other vessels since the blow. Nearly every vessel met with more or less disaster, losing cable and anchors, booms, masts, or were so badly stove up as hardly to be able to get back to port. One by one they came along until the number narrowed down to thirteen, who with their crews had left port for their last fishing trip.

Two of the vessels were abandoned, the crews having narrow escapes. Thure was general sorrow throughout the community. Many of the best skippers of the town were lost in this gale, as several of them were on board. some of the vessels lost, having taken this trip as their own vessele were not quite ready to start. There were lost in this gale one hundred and twenty men and fifteen vessels, leaving seventy widows and one hundred and forty fatherless children. In addition to this terrible disaster, there were lost, previous to this gale, thirty-eight men and four vessels. One each in the Georges, Bank, Newfoundland and shore winter fisherics, making an aggregate of nineteen vessels in all, and one hundred and sixty-two men.

The losses in the February gale were as follows:

Schooner ENTERPRISE, nine men, viz. : Henry Peterson, Mạster ; 
John Foster, Charles Brown, Hervey Peterson (son of master), Ernstus Rackliffe, $\Lambda$. E. Benson, Wm. Baryson, F. II. Quimby, and one man, name unknown. Owned by Geo. F. Wouson \& Bros. Val. ued at $\$ 4,000$; insuresl for $\$ 3,500$.

Schooner GLORGE F. WONSON, nine men, viz.: Artemas Cameron, Master; Gorlıam Clark, Jr., Elijalı Gardner, Wm. Dingle, MInrdock McNeil, Thomas W. Firth, John Lind, Joseph Atwater, Wm. Strand. Owned by Capt. Artemas Cameron. Valued at $\$ 3,500$; insured for $\$ 3,000$.

Schooner MAY QUEFN, nine men, viz.: Georgo Brant, Master ; John Simitl, Alex. Hutehins, Matthew Olson, Samuel Parsons, James Webb, Benj. F. Parsons, John W. Jolnnson, James Hudson. Owned by $W m$. Parsons, $2 d$, \& Co. Valued at $\$ 3,800$; insured for $\$ 3,325$.

Schooner OCEAN FLOWER, nine men, viz. : Joln Carney, Master; James Fitzpatrick, James Brady, Dennis Olentt, James Breman, Daniel Conway, Cornelius Fluen, Daniel Long, John Griffin. Owned by Charles Parkhurst. Valued at $\$ 3,600$; insured for $\$ 3,150$.

Schooner OCONOMOWOC, ten men, viz.: Dennis S. Kelly, Master; John Henderson, John P. Parsons, John MeNash, John Murphy, James Parsons, Michael Murphy, Dennis Kelly (master's son), Joseph Brown, John Jerret. Orned by Charles Parkhurst. Valued at $\$ 3,200$; insured for $\$ 2,800$.

Schooner NORTH STAR, nine men, viz.: James Roach, MIaster; Thomas Foley, James Donnelly, Joseph Brown, Thomas Jones, Otis Scarborongh, Thomas Tobin, James IIenderhan, Richurd Harris. Owned by Charles Parkburst. Valned at $\$ 2,800$; insured for $\$ 2,450$.

Schooner CONTEST, nine men, viz. : Joln Crawley, Master; Peter Lunderkin, John Sterling, Robert Corcoran, Robert Hambleton, Michael Wallis, James Foley, Michael Welsh, James Corwin. Owned by George Friend \& Co. Valued at $\$ 4,200$; insured for $\$ 3,675$.

Schooner NEBRASKA, nine men, viz.: Spencer Olmore, Master; Manuel Williams, Samuel Blatchford, Jr., Levi Gove, Manuel Joseph, Joln Yeaton, Manuel Silva, Frank Perry, Joseph Silva. Owned by George Friend \& Co. Valued at $\$ 3,200$; insured for $\$ 2,800$.

Schooner CLARA EVA, nine men, viz.: Wm. 'T. Rogers, Master; Manuel Zuza, Manuel Innis, Daniel G. Grindle, Richard Carter, Wm. 'T. Young, Joseph Silva, John Dickson, Manuel Peter. Owned by Charles Friend \& Co. Valued at $\$ 3,000$; insured for $\$ 2,625$.

Schooner ANNIE LAURIE, nine men, viz.: Charles Dunnells, Master; Henry Carter, Peter Brant, George Walker, Johu O'Neil, 
Joseph Lawrence, John Jenkins, George Folger, Andrew Fults. Owned by Joln Pew. Valued at $\$ 3,600$; insured for $\$ 3,150$.

Schooher JOHN J. CRITTENDEN, ten men: Joseph McCarty, Master; Joseph McCallbeck, Samuel Colby, Frederick Scott, Timothy Currier, William Kiley, Michael Stapleton, Michael Daniels, Daniel McAdams, David Bankham. Owned by Pettingill \& Cunningham. Valued at $\$ 4,200$; insured for $\$ 3,675$.

Schooner ANGLO SAXON, ten men, viz.: George W. Barbour, Master; Michael Hogan, Wm. Low, King Crine, Frank Veader, Joseph Carry, Henly Hall, Mannel Silva, John Williams, James A. McKay. Owned by Fitz E. Riggs \& Brother. Valued at $\$ 4,000$; insured for $\$ 3,500$.

Schooner DREADNAUGHT, nine men, viz.: George F. Dunnels, Master; Manuel Silver, David Lurvy, William T. McCrate, John Silver, Josiah Scott, Charles N. Baker, Jacob Hopster, Reuben Walker. Owned by Pettingill \& Cunningham. Valued at $\$ 3,600$; insured for $\$ 3,150$.

Schooner BORODINO, Knight, Master; was disabled and abandoned on Georges. Crew taken off by schooner Peerless, and brought to this port. Owned by George Steele. Valued at $\$ 3,000$; insured for $\$ 2,625$.

Schooner QUICKSTEP, Brewer, Master; was also disabled at the same time. Crew taken off by schooner Northern Chief, and brought to port. Owned by George F. Wonson \& Bros. Valued at $\$ 3,200$; insured for $\$ 2,800$.

\section{LOSSES PRIOR TO THE FEbRUARY GALE.}

Schooner CYNISCA was lost on Western Bank, January 1st, with nine men, viz.: Adam Hunter, Master; Daniel Smith, Fletcher MePherson, Frederick Warren, Lawrence Hunter, Murdock Matthewson, David Martin, Archibald Black, Calvin C. Campbell. Threequarters of her were owned by Capt. Hunter \& Bro., and the balance by David W. Low. Valned at $\$ 3,600$; insured for $\$ 3,000$.

Schooner LIFE BOAT was lost in the gale of January 1st, with nine men, viz.: Curtis Hodgkins, Master; Dunean M. Cunningham, Angus Grant, John Skillan, John Haines, Charles Kempton, Solomon Conard, John Chisholm, John 'T. Shrider. Owned by David C. Babson \& Co. Valued at $\$ 4,000$; uninsured.

Schooner OCEAN TRAVELLER was lost on her passage to Newfoundland, in the gale of January 1st, with her crew of ten men, viz. : John F. Smith, Master; John R. Johnson, John Gardner, John McKinnon, Samuel Durgin, Richard Anderson, Patrick Parsons, 
Joln Roach, B. Hill, George Ebenezer. Three-quarters owned by the master, and the remainder by Sanuel W. Brown. Valned at $\$ 4,000$; insured for $\$ 2,500$.

Schooner OREGON, lost January 20th, on Quaddy Head, with eight men, viz.: S. Guptil, Master; J. Ingersoll, Jolnn O'Brien, Wm. MIcDonald, Eben Wormell, M. Handlan, Henry Mofmit, Simon Hanley. Owned by George F. Wonson, and otliers. Valued at $\$ 2,000$; insured for $\$ 1,500$.

Rrciurd Wheatos, lost overboard from schooner Kit Carson, on her homeward passage from Newfoundland, January 10 th.

Willias Campbell, lost overboard on Georges, fiom schooner Sea Foam, in March.

Dixiel Desmoxd, of schooner $\Lambda$. R. Anilrews, lost overboard Oct. 12th, off Thacher's Island.

Jasies L. Buck, of sehooner Wild Rover, lost overboard on the passage home from the Bay of St. Lawrence, in October.

Joun McDoxald, of schooner Flying Fish, was drowned $\Lambda_{\text {pril }}$ 20 th, by falling between the ressel and wharf.

George E. Webber, of this town, one of the crew of schooner Glad Tidings, died at Prince Edward's Island, August 10th, of typhoid fever.

\section{3.}

There were nine vessels and six lives lost in the fishing business this year: two vessels in the Newfoundland, and one in the Bank fishery. The pirnte Tacony made a raid on the fishing fleet at anchor in the South Channel, June 22d, burning six of the ressels.

Sehooner WILLIAM PARKMAN was dismasted.off Beaver Island, in a gale, and was subsequently torved into Beaver Harbor, and sold. One of the erew, named Philip Caner, was drowned. Owned by George Stecle. Valued at $\$ 3,200$; insured for $\$ 2,800$.

Schooner ALFALFA was lost at English Harbor, Newfoundland, in January. Crew saved. Owned by Charles Parkhurst. Valued at $\$ 2,500$; insured for $\$ 2,000$.

Sehooner MARY E. HILTZ, Joln Hiltz, Master; was lost off Marblehead, on her homeward passage from Newfoundland, February 26 th, during a violent snow storm. One of her crew, named Tromas Curistopher, was drowned. Owned by the master and George P. Rust. Valued at $\$ 7,500$; insured for $\$ 3,500$.

The following are the names of the vessels burned by the Tacony. They were valued at $\$ 25,000$, and insured, but the manner of their being destroyed rendered the insurance invalid. Claims lave been 
made upon the Gorerument for indemnification, and it is presumed that the insurance money will be paid by the United States.

Schooner MARENGO, owned by George Steele.

Schooner RIPPLE, owned by Wm. A. Pew.

Schooner ELIZABETH ANN, owned by Fitz E. Riggs.

Schooner RUFUS CHOATE, owned by Pettingill \& Cunningham.

Schooner WANDERER, owned by George Perkins \& Co., and her master, Capt. Charles H. Pierce.

Schooner ADA, owned by James Power and James Tobin.

James Murpity and Daniex Buchley, were lost overboard from schooner Horatio Babson, Jr., on Georges, in February.

Robert Mrtchell, of Kittery, Mre., lost overboard from schooner Oliver Burnham, Feb. 16th, on passage to Georges.

Benton Lewis, of Boothbay, Me., lost in the Bay of St. Lawrence, Nov. 9 th, from schooner Charlotte Brown.

\section{4.}

This was another disastrous year to the fishermen, proving "with the exception of 1862, the most unfortunate since the Georges fishery commenced. By these sad disasters to the fishing fleet, eightyfive men found a watery grave, and thirteen vessels were lost, viz.: eight on Georges, two in the Bay of St. Lawrence, two in the Newfoundland fishing, and one in the freighting business.

The night of March 22d will long be remembered as the commencement of a severe northeaster. There were at this time about one hundred sail on Georges, and the howling of the wind carried sad forebodings to many anxious wives, mothers, and other near and dear friends of the Georgesmen. They knew full well that nothing short of a miracle would bring all of that fleet back to port, and the dread question, who will be lost? repeated itself over and over again in the mincls of the anxious watchers here at home. It was a solemn time, and all hearts felt that again there were to be lamentations for those who would never return; and finally, when one by one these Gcorgesmen came creeping back to port, and clays and weeks passed in anxious hope that others wonld follow, it was found that six were missing, as follows :

Schooner JOHN G. DENNIS, with ten men, viz.: Andrerv D. Bartlett, of Southport, Me., Master ; Joel W. Bartlett, (his brother,) Wm. F. Dunton, Franklin Towle, both of Southport; Amos Stinson, Deer Isle, Me.; Stillman Spinney, Thomas McDonald, An- 
drew Snyder, Danicl IIolly, James Rogers, of this town. Owned by Slute \& Merchant. Valued at $\$ 5,500$; insured for $\$ 4,500$.

Schooner LIGHT OF HOME, nine men: Thomas J. Moody, Master; Simeon MIoorly (his hrother), Joln Buote, Willian Frazier, James Quirk, Francis Dousett, George Barbou', James Duyer, Jolun Sinith, all of this town. Owned by Epes Saywarl \& Co. Valued at $\$ 6,000$; insured for $\$ 4,375$.

Sehooner OLIVER BURNHAM, nine men: Paul Busliy, Master; Isaac Bushy (his brother), Charles Mace, Samuel C. Mace (his brother), Newburyport; Ephrain T. Briggs, Charles King, Charles B. Marshall, Michael Doursey, Charles Clark. Owned by Charles Friend \& Co. Valued at $\$ 3,800$; insured for $\$ 2,450$.

Schooner NAWADAHA, ten men: James Power, Master; Edward Power (his brother), Michael Maddix (nephew to master), William Murphy, Alex. Maney, David Cushman, all of this town; John IIandrahan and Peter Giddings, of Newburyport; one man, name unknown. Owned by H. C. Knapp \& Co. Valued at $\$ 7,000$; insured for $\$ 6,500$.

Schooner EMMA FRANCES, nine men : Jolm C. Mellows, of Chat. ham, Master' Manuel Rose, Joseph Wood, Joseph Silva, Jr., Geo. Williams, Andrew Francis, John Williams, Charles Silva, C. H. Orr (a stranger, and it is not known where he belonged). Owned by David Parkhurst and Edward \& William Babson. Valued at $\$ 5,000$; insured for $\$ 3,150$.

Sehooner R. E. SPOFFORD, ten men; James Smith, Master; Louis Graves, James McKellan, Martin Parkel, Benjamin Low, Charles Dahl, Augustus Swinson, John Carly, Augustus Collins, Stephen MeGrath. Owned by Clark, Rust \& Co. Valued at $\$ 8,000$; insured for $\$ 4,000$.

To many families the losses in the above gale came with double severity, as four of the vessels had brother's on board, viz. : the Bartletts, of Westport, MIe. ; the Maces of Newburyport, and the brothers Powers and Moody of this tomn. Amos Stinson, lost in the J. 'G. Dennis, was a brother to Ira, lost from the sehooner Emma Frances, in the same gale. Capt. Powers, of the Nawadaha, was formerly master of the Ada, which was burned by the pirate Tacony, in 1863 .

In addition to the above, there were two vessels and their crews lost on Georges, in the February gale, as follows :

Schooner RAVEN, nine men: John Kínnelly, Master; John Shuttleworth, Charles MIcLillan, Benjamin Crittenden, Nicholas Foley, William Wallace, Manuel Rogers, George L. Dresser, Alex. 
Terry. Owned by Pettingill \& Cunningham. Valued at $\$ 3,600$; insured for $\$ 3,150$.

Schooner GORHAM BABSON, nine men: Daniel McPhee, Master; James Greenleaf, William Swin, Thomas Spring, John Murphy, Angus Sutherland, Daniel Ready, Archibald McDonald, Elijah Demings. Owned by H. C. Knapp \& Co. Valued at $\$ 7,000$; insured for $\$ 5,500$.

Schooner KOSSUTH was lost in the Newfoundland fishery, at Owl's Harbor, Halifax, Feb. 15th. Crew saved. Owned by H. C. Knapp \& Co. Vessel and cargo valued at $\$ 12,000$; mostly insured.

Schooner FEARLESS, in the Newfoundland fishery, lost on Miquelon Island. Crew saved. Owned by Robert Fears. Valued at $\$ 5,500$; insured for $\$ 3,500$.

Schooner FLEETWING was lost in the Bay of St. Lawrence, on the 20th of August. Crew saved. Owned by Capt. Peter Sinclair and Capt. James Ayer. Valued at $\$ 6,500$; insured for $\$ 4,500$.

Schooner OROZIMBO, went ashore at Chetticamp, on the 18th of October, and became a total loss. Crew saved. Owned by Benjamin Haskell. Valued at $\$ 8,000$; insured for $\$ 4,000$.

Schooner TRIUMPH, Capt. Campbell; was run down and sunk on her passage to New York, March 17th, by ste:tmer Western Metropolis. The captain and three of her crew were saved by a boat from the steamer, but two of the crew, Jonn Millen, of Kittery, Me., and Lighthill Pearce, of Bristol, Me., were drowned. Owned by John Low, Jr. Valned at $\$ 9,000$; insured for $\$ 2,000$; cargo valued at $\$ 12,000$, and insured for $\$ 2,000$.

Joms Devine, lost overboard and drowned on Georges, in February, while furling jib. Body recovered and brought home.

Heryan Lane, of schooner Sea Foam, son of Theodore Lane, was knocked overboard and drowned off Block Island, in June.

Francis Augustes, a Frenchman, was lost overboard from schooner Emma Parsons, off Noman's Land, in June.

Ira Stinson, of Deer Isle, Me., was washed overboard and drowned on Georges, March 23d, from schooner Ellen Frances.

William Grant was lost overboard and drowned in the Bay of St. Lawrence, in June.

Josepri O'Brien, of schooner Joseph Story, was washed overboard and drowned off Cape Sable, April 23d, while returning from Western Bank.

Warren Richardson was lost overboard and drowned on Georges, March 29th. 
William Fisien, son of Jacob F. Fisher, lost overboard from schooner Boston Light, on passage to Boston, April 26 th.

\section{5 .}

There were eleven lives and eight vessels lost this year, as follows: two vessels in the porgie oil business, two trading vessels, one in the Bay of St. Lawrence fishery, one in the Newfoundland trade, one Western Banker, and one in the Prince Edward Island trade.

Schooner J. L. GERRITY, Knapp, Master ; was wrecked on Stirrup Key, in $\Lambda$ pril, while on her passage to New Orleans, with a cargo of mackerel. Crew savel. Owned by II. C. Knapp. Valued at $\$ 6,500$; insured for $\$ 6,000$.

Schooner NORTHERN CHIEF was run down and sunk by the English steamer Bosplorus, off Cape Sable, May 31st, while on her returu from Western Bank. She had a erew of eleven men, five of whom were in the cabin, and rushing on deck, succeeded in scrambling up the rigging and getting on board the steamer, just as the sebooner was going down. The other six were drowned, viz.: Winslow R. Hopkins, of Vinalhaven, Me., Master; John Lindsey, James Colby, Peter Welch, William Parkhurst, Jobn Kent. The disaster was attributed to carelessness on the part of those keeping watch on board the steamer. Owned by John Low \& Son. Valned at $\$ 9,000$; insured for $\$ 6,000$.

Sehoonel SWAN, of Annisquam, porgie oil business, was lost near Madison Point, Conn., July 20th. Crew saved. Orsned by George Butler and Epes Davis, Jr. Valued at $\$ 1,800$; insured for $\$ 1,400$.

Schooner EDWIN, loaded with bricks and lumber, sank on the night of July 31st, about ten miles N. E. of the Isle of Shoals. Crew saved. Owned by William P. Dolliver. Valued at $\$ 1,500$; insured for $\$ 1,000$.

Sehooner SEA FAN, in the porgie oil business, was lost on York Ledges, Oetober 14th. Crew saved. Owned by Wm. P.-Dolliver and $\Lambda$ dclison Procter. Valued with her outfits at $\$ 2,500$; insured for $\$ 2,000$.

Schooner S'T. LAWRENCE, engaged in the Bay mackerel fistery, was lost near Ragged Island, on her passage home, early in November. Crew sared. Owned by George Brown. Valued at $\$ 3,500$; insured for $\$ 3,000$.

Schooner MINTERVA was lost near Pictou, N. S., on the 24th of November, while on her Lomeward passage from Prince Edward 
Island, with a load of produce. Crew saved. Owned by C. C. Pettingill and Capt. Robert Allen. Valued at $\$ 3,500$; insured for $\$ 3,000$.

Schooner COI، ALLEN was lost near Louisburg Harbor, C. B., December 10 th, while on her passage to Newfoundland. Crew saved. Owned by Daniel Sayward. Valued at $\$ 12,000$; insured for $\$ 10,000$.

Cirristopher Crocse, a native of Liverpool, N. S., was lost overboard from schooner Carrie E. Crouse, on the passage from Newfoundland, February 3d.

Horatio Bartlett, of Camden, Me., one of the crew of schooner William Babson, was washed overboard on Georges, April 30th, and drowned.

CAPt. Jonn McLellan, master of schooner Sabine, was lost overboard on Georges, while at the wheel, February 12 th.

Axgus E. Gillis and Thomas E. LADD, two of the crew of schooner Prince of Wales, were lost overboard and drowned, May 17th, while on the passage from Surinam.

1866.

Twenty-six lives and fifteen vessels were lost this year, as follows: three ressels in the Georges fishery, three in the Bay of St. Lawrence, three in the shore, two in the Newfoundland, and four in the freighting business.

Schooner JAMES SEWARD, lost off Rockland, Me., Norember 14th, while on her passage home from the Bay. Crew saved. Owned by David Parkhurst. Valued with her cargo at $\$ 8,000$; insured for $\$ 6,820$.

Boat MARY, sank while coming from Boston, May 1st. Crew saved. Owned by John Clark, 3d. Valued at $\$ 700$; no insurance.

Schooner CLARION, lost off Newport, R. I., in May. Crew saved. Owued by Addison Procter, and others. Valued at $\$ 2,550$; insured for $\$ 2,250$.

Schooner BOXER sprung aleak and sank off Eastern Point, on the night of Nov. 17th. Crew saved. Valued at $\$ 800$; insured for $\$ 700$.

Schooner DWIGHT, in the freighting business, lost near Key West, in January. Crew saved. Owned by Capt. Oliver G. Lane, Annisquam. Valued at $\$ 11,000$; insured for $\$ 9,000$.

Schooner CARRIE E. CROUSE, lost on the passage to Baltimore, in February, with her crew of six men, as follows: William L. Crouse, Master; George Gerring, Hugh McLain, Wm. Howlett, 
John McLain, Robert Swallow. Owned by John Perkins \& Co. Valued nt \$12,000; insured for $\$ 10,000$.

Seliooner D. L. STURGIS was disabled while on her passage to Rochelle, and put into Bermuda, where she was condemned. Orrned by Francis W. Homans, and other's. Valued nt $\$ 11,000$; insured for $\$ 9,000$.

Scliooner GEORGE J. MARSH was lost off Magrlalene Islands, in September, while $\mathrm{cn}$ the passage from Jvitgut, Greenland. Crew saved. Owned by Capt. Samuel Irwin, George J. Marsh, and others. Valued at $\$ 31,000$; insured for $\$ 14,000$.

Schooner M. C. ROWE, lost in January, while on the passage from Newfoundland. Crew saved. Owned by David Low \& Co. Valued at $\$ 10,500$; insured for $\$ 8,000$.

Schooner GEN. SHERIDAN, lost off Cape Canso, January 14th, on the passage liome from Nerfoundland. Four of the crew were lost, viz.: James Pringle, Robert Dahl, George IIoward, Thomas Harris. Owned by Walen \& Co. Valued at $\$ 12,000$; insurecl for $\$ 10,000$.

Schooner ARCTURUS, in the Georges fishery, struck on L'Ilommadieu Shoal, May 3d, and was sunk. Crew saved. She was abandoned to the underwiters, and subsequently raised and sold. Owned by James Mansficld \& Co. and Capt. Eben Davis. Valued at $\$ 2,400$; insured for $\$ 2,250$.

Sebooner SARAII sprung aleak and sank on Georges, July 16th. Crew saved. Owned by William II. Oakes and George II. Smith. Valued at $\$ 2,800$; insured for $\$ 1,700$.

Schooner CLARA DAVIS, lost on Georges in the gale of October 18tb, with all her crew of eight men, viz.: Matthew Caig, Master; Gcorge Zwicker, Edward Marshall, Richard Troy, Charles Lunt, John Wade, Peter Burke, Joseph Silva. Orned by James Mansficld \& Sons. Valued at $\$ 3,000$; insured for $\$ 2,675$.

Schooner MARTIA \& ELIZA was run down and sunk by schooner Nortlierner, on the 30th of August, near Magdalene Islands. Crew saved. Owned by Joseph O. Procter. Valued at $\$ 4,200$; insured for $\$ 3,675$.

Schooner ARCOLA, drove nshore at Port Hood, on the 4 th of October, and became a total loss. Crew saved. Owned by Gustavus Grifin \& Son, of Annisquam. Valued at $\$ 2,300$; insured for $\$ 2,025$.

Four men were lost from the wreck of schooner Maggie McLane, which was being towed in by the sehooner Lady Franklin, on the 
night of March 20th. Their names were Jons This, of Norway; Murdock Finlaysun, of Guysboro', N. S. ; Rhoderick McDonald, of Straits of Canso; Andrew Perkins, of York, Me.

DANiEL FARDY was lost overboard from schooner Arizona, bound for Georges, on the night of September 21st.

Lewis A. McDonald was lost overboard from schooner E. R. Nickerson, on the 20th of August, off Magdalene Islands.

William MrLler, of Lanesville, was lost overboard from schooner Emporia, Aug. 27th.

William Davis was lost overboard from schooner Carrie S. Dagle, January 10th, on her passage from Newfoundland.

\section{7.}

There were sixty-six lives and eleven vessels lost this year, as follows : three on Georges, one in the Newfoundland trade, three in the Bay. of St. Lawrence, two in the shore fishery, and two freighters.

Schooner JOHN W. LOWE, probably lost in the gale of January 17th, while on the passage from Newfoundland. Crew of nine men, viz.: Manly Grimes, Master; Gustave Witer, Raymond White, George H. Griffin, James Hanler, Oliver Norton, Augustus Dagle, Henry Kappin, Neal McKinnon: Owned by John Low, Jr., \& Son. Valued with cargo, at $\$ 15,000$; insured for $\$ 12,000$.

Schooner FRANK HERBERT, lost on Georges, in August. Crew of eight men, viz. : Patrick Flaherty, Master ; Hugh McDonnough, Michael McDonnough, James King, Thomas Mullen, Michael Flaherty, Martin Foley, Mark MoLaughlin. Owned by Hugh McDonnough and Samuel Lane \& Bro. Valued at $\$ 4,500$; insured for $\$ 2,200$.

Schooner SUNNY SIDE, lost on Georges, same month. Crew of nine men, viz.: John Grant, Master; Henry Beckman, John Myers, Peter Frederickson, Peter Peterson, Hans Anderson, Alexander Colson, William Wilson, James Kirby. Owned by Walen \& Co. Valued at $\$ 7,000$; insured for $\$ 5,500$.

Schooner ONWARD had a narrow escape on Georges in the gale of August 2d. She was boarded by a heavy sea, which swept away bowsprit, masts, bulwarks, \&c., making a complete wreck of the vessel above her deck. Fortunately no lives were lost. Owned by Wm. Parsons, 2d, \& Co. Abandoned to the underwriters and sold at auction for $\$ 1,000$. Valued at $\$ 3,500$; insured for $\$ 3,062$.

Schooner FASHION, lost in the Bay of St. Lawrence, in the September gale. Crew of thirteen men, viz. : John Peterson, Master; 
Parker Moody, John Willians, James Montgomery, John Cadeel, Antone Prater, Frank Prater, Antone Silva, Allen O'Brien, Thomas Thomas, and three others, nanes unknown. Owned by Samuel Haskell. Valued at $\$ 4,500$; insured for $\$ 3,557$.

Sclooner WATER SPIRIT went ashore at Chetticamp, in the gale of September 30th. Crew saved. Ahaudoned to the underwriters. Owned by George Garland. Valued at $\$ 9,075$; insured for $\$ 7,525$.

Schooner LADY FRANILLIN went ashore in the same gale, at Malpec. Abandoned to the underwriters. Owned by Willian Parsons, $2 \mathrm{~d}$, \& Co. Valued at $\$ 5,600$; insured for $\$ 4,900$.

Schooner STAR OF TIIE EAST, in the shore mackerel fishery, sank on a ledgo off Wood Island, September 29th. Crew saved. Owned by Capt. Charles M. Curtis and Joseph Friend \& Co. Valued at $\$ 9,000$; insured for $\$ 7,525^{\circ}$.

Schooner WATER WITCH, in the scining business, lost off Matinicus Island, Me., Aug. 3cl. Crew saved. Owned by Capt. Addison Wonson, and others. Valued at $\$ 2,000$; no insurance.

Schooner COL. ORNE was run down and sunk while on her homeward passage from New York, Mray 14th. Crew saved. Owned by Capt. Samuel Elwell, Jr. Valued at $\$ 2,500$; insured for $\$ 1,800$.

Schooner JENNIE TYLER, lost in August, on her passago from Para to New York. Eight men, viz.: Solomon Frellick, Master; E. King Coas, mate; Davicl Smith, Heury Robinson, Louis Dyer, James Hamilton, and two Srreles, names unknown. Owned by William Parsons, $2 \mathrm{~d}$, \& Co., and others. Valued at $\$ 20,000$; insured for $\$ 11,000$.

IsAAC BAKER, of Manchester, was drowned from schooner Belle Brandon, May 12th, while lying in Newport IIarbor.

William Blair, one of the crew of schoonel Theron J. Dale, was lost overboard on the passage to Demarara, on the 30th of April.

Michael Mralciry, mate of schooner Rattler, was lost overboard in the gale of January 17th, while on the passage from Newfoundland.

James F. Soutnerlaxd, mate of schooner Setagawa, and Jonx TCFTs, mate of schooner George O. Ilovey, were ilowned on the honeward passage from Newfoundland.

Daxiel Bunnilan was lost overboard from selooner Arequipa, on the 23d of November, while on the passage to Newfoundland.

Saycel Ronerts was lost overboard on Georges from schooner Lookout; Geonge Scrales, from the Samuel Wonson; J. A. 
HAVerner, from the Northerner; JAmes McDonald, from the Barbara Frietchie, on her homeward passage from Western Bank.

Edward Mitchell, Thomas Herring, Matthew Silver, and Albert Bigelow, were lost overboard, on the $2 d$ of June, from schooner Hattie M. Lyons; WilliaM L. Nickerson, and LeWIS DoAne, from schooner J. II. Nickerson, on the 1st of June. These crews were in the Grand Bank fishery.

HenRy Sinotr was lost overboard from schooner Roger Williams, October 23d, while on the homeward passage from the Bay of St. Lawrence.

Bradford Tromas, lost from schooner C. C. Pettingill, in the gale of September 30th.

Capt. Alexander Benson, of schooner Montrose, died quite suddenly on the 24th of October, of hemorrhage, while engaged in fishing on Georges.

\section{8.}

There were thirty-nine men and four vessels lost this year, as follows : two in the Bank fishery, one on Georges, and one freighter.

Schooner IDAHO, was probably lost in January; she was engaged in the Grand Bank fishery, and had a crew of eight men, as follows : Samuel F. Wennerberg, Master ; Charles Anderson, Charles Benson, Jolnn Rutledge, Thomas Dunn, John Parker, Henry Rutherman, Charles Hayden. Owned by George Garland. Valued at $\$ 9,000$; insured for $\$ 7,000$.

Schooner GENERAL BUTLER was lost in the Georges fishery, in June. Supposed to have been run down. Had a crew of ten men, as follows: Sereno W. Campbell, Master; Frank Brown, James Sherman, David Lane, Jr., Edward Duncan, Joseph Hobbs, Waitsell Nickerson, George Oram, and two others, names unknown. Owned by D. C. \& H. Babson, Jr. Valued at $\$ 6,000$; insured for $\$ 5,250$.

Schooner JAMES S. AYER was lost in December, in the Grand Bank fishery. Had twelve men, viz.: John R. McDonald, Master; Colin McDonald (brother of master), Murdock McDonald, Stephen McDonald, Philip Riley, Whitfield Spinney, John W. Brown, Daniel Kennedy, Michael McCormick, Angus McPhee, Daniel MIcIntire, J. E. Osier. Owned by Dennis \& Ayer. Valued at $\$ 8,000$; insured for $\$ 6,900$.

Schooner LIZZIE F. CHOATE, in the freighting business, lost in the gulf stream, Feb. 7th, while on the passage from New York to Antigua. Three of her men were lost, viz. : David Gaffney, Master; 
Henry Gaffney (brother of the master), Benjamin Marston. The remainder of the crew, Reuben McKenney, Hugh McKinnon, Charles Nelson, remained on the wreck five days, when they were taken off by the British brig J. S. Wright. Owned by Walen \& Co. Valued at $\$ 12,000$; insured for $\$ 9,000$.

Fraxk Caarbell was lost overboard from schooner Franklin Snow, on the 21st of February, while furling the jib.

David Hisckley, of Cape Breton, was lost overboard from schooner Isaac Somes, on the $27 \mathrm{th}$ of $A$ pril, while reefing the mainsail.

Chalies Deitricir, of Newburyport, and James Learx, of Rockport, were lost from schooner Abby Dodge, in May, while visiting their trawl.

'Tuomas Ealize was lost overboard from schooner Farragut, Feb. 14tb, shortly after leaving port, bound for Georges. He was a native of Gosport, England.

Martin Hexdersox, of Beverly, was lost overboard from schooner Rambler, $A$ pril 15th, while reefing mainsail.

Charles Foster of Guysboro', N. S., was lost from sehooner Florence Reed, Nov. 10th, while on the passage from the Bay.

\section{9.}

Sixty-six lives and sixteen vessels were lost this year, as follows: five in the Georges fishery, two in the Bank fishery, four in the shore mackereling, three freighters, one in the oyster business, and one pilot boat.

Schooner AUGUSTUS E. PRICE was lost on Georges in the gale of Marel 6th. Crew of eleven men, viz. : Baruabas Horton, Master ; Henry Williams, Charles Hicks, Willian Kelley, Isaac Austin, John W. Rowe, Thomas Cameron, Levi W. Cole, Charles Swim, Frank Hedman, Freeman Goodwin. Owned by McKenzie, Knowlton \& Co. Valued at $\$ 9,000$; insured for $\$ 7,000$.

Schooner MIARTHA A. PORTER was lost in the same gale, with nine men, viz.: Joseph O. Shackelforcl, Master; Henry F. Wonson, James Cam, William J. Ripley, George Campion, Robert Johnson, Charles Cunningham, Richard Morris, Jobu Croekett. Owned by Clark \& Somes. Valued at $\$ 5,600$; insured for $\$ 4,762$.

Sehooner ABIGAIL C. WOODBURY, lost in the gale of March 7th. Crew of eleven men, viz.: Edward Welch, Master; James Ryan, James Mannering, Joseph Franeis, Matthew Murray, Michael Finley, Mark Lyons, Michael Carroll, Charles Camplell, Arehibald Campbell, and one man, name unknown. Orned by D. C. \& H. Babson, Jr. Valued at $\$ 9,600$; insured for $\$ \pi, 000$. 
Selooner A. R. ANDREWS, lost in the same gale. Crew saved. Owned by Charles Parkhurst. Valued at $\$ 3,400$; insured for $\$ 2,975$.

Schooner IZAAK WALTON came into collision with schooner William Babson, while returning from Georges, Sept. 26th, and sank shortly afterward. Crew saved. Owned by D. C. \& H. Babson, Jr. Valued at $\$ 5,500$; insured for $\$ 3,500$.

Schooner FOREST BELLE was lost in the Grand Bank fishery, probably early in. January. She was a new vessel and on her first trip. Had a crew of twelve men, viz. : Moses M. Welch, Master; Robert M. Collins, Daniel Lufkin, Randall McLellen, Arthur Ulmer, Sylvanus Gott, George Bartlett, George Kane, John A. Kelley, James McDonald, William Hicknan, Williain B. Rowe. Owned by Rowe \& Jordan. Valued at $\$ 10,300$; insured for $\$ 5,000$.

Schooner ABBY H. SWASEY was lost on Half Moon Beach, off Cape Negro, July 12th, on her homeward trip from the Grand Banks. Crew saved. Owned by George Dennis \& Co. Valued at $\$ 6,000$; insured for $\$ 4,500$.

Schooner POTOMAC, in the mackerel fishery, went ashore at Orc's Island, Me., Sept. 8th, and was a total loss. Crew saved. Owned by Brown Brothers. Valued at $\$ 2,500$; insured for $\$ 1,950$.

Schooner ALABAMA, in the mackerel fishery, went ashore at Kennebunk in the same gale, and proved a total loss. Crew saved. Owned by George Dennis \& Co. Valued at $\$ 2,000$; insured for $\$ 1,350$.

Schooner ANDES was totally wrecked at Boothbay, Me., in the same gale. Crew saved. Owned by Joseph Andrews \& Son, Lanesville. Valued at $\$ 500$; no insurance.

Boat RAMLBER was lost off Portland at the same time. Owned by Joseph Andrews \& Son. Valued at $\$ 250$; no insurance.

Schooner THERON J. DALE, in the freighting business, lost at Baracoa, April 24th. Crew saved. Owned by Capt. Jesse Lewis. Valued at $\$ 10,000$; insured for $\$ 7,500$.

Schooner A. D. RICE, in the oyster business, lost in March, Alexander McLane, of East Boston, Master. Crew' of five men, names unknown. Owned by Gustavus Grifin \& Son, of Annisquam. Valued at $\$ 9,000$; insured for $\$ 5,000$.

Schooner CHARLES A. STETSON went ashore on the bar at Indian River, March 22 , and proved a total loss. Owned by Capt. Abraham Babson. Crew saved. Valued at $\$ 5,000$; no insurance.

Schooner TWILIGHT, sunk off Beaver Island, January 29th, while on her passage home from Guysboro', N. S., with a cargo of frozen 
eels. Crew saved. Owned by George Garland. It was subseq̧uently ascertained that the vessel was scuttled by the captain. Valued at $\$ 4,000$; insured for $\$ 3,000$.

Pilot boat YOUNG RAVEN was driven ashore on Pavillon Beach, in this harbor, in the gale of Sept. 8 th, and became a total loss. Owned by David H. Ellery and Robert Callahan. Valued at $\$ 800$; insured for $\$ 600$.

Capt. Josepu Martis was lost overboard from schooner Emporia, in the galo of Sept. 8th.

George Bowden was lost overboard from schconer Belvidere, October 10th.

Sajecer Swainson was lost overboard from schooner Sabine, March 2l.

MAANEel Rogers was lost overboard from Schooner Marion Grimes, March 6th.

Willas Gardser, of Southport, Me., was lost overboard from schooner Soplironia, February 28th.

Jonx SMrn was lost orerboard from Schooner Henry Ellsworth, March 7tb.

Sajreel Surtr was lost overboard frou schooner Veteran, March 7 th.

JoIIN WeLci and ANThosy White were lost overboard from schooner Mary Anna, October $2 d$.

Pullip Perriway was lost orerboard June 27th, from schooner Enola C., while returning from the Grand Banks.

Jom MicQuarrie and Finfey McMillex, of schooner Havey C. Mackay, were lost Feb. 23»l, while visiting their trawls.

Capt. John B. Woodiury, of schooner James A. Stetson, and Robert Staups, one of the erew, were lost April 23d, in a similar manuer.

T. Frani Wixcnexbaucil and Srlvestel Riley were lost from schooner Gleumood, April 22 d.

Martix Dosaltix was lost overboard from schooner Catalina, in the shore mackerel fishery, in June.

\section{0.}

Thirteen ressels and ninety-seven lives were lost this year, as follorrs : four ressels on Georges, two in the Bank fishery, tro in the Bay of St. Lawrence, one in the shore mackerel fishery, two in the herring fishery, and tro in the coasting business.

Schooner POCLMTUCK, engaged in the Western Bank fishery, 
was run ashore near Ship Harbor, N. S. Condemned and sold, the master pocketing the receipts. Owned by Capt. Sargent S. Day. Valued at $\$ 3,000$; insured for $\$ 2,652$.

Schooner GEORGE R. BRADFORD was lost in February, on the homeward passage from Newfoundland. Crew of six men, viz. : John Wolfe, Master; Thomas Tobin, John Herring, Alexander Grant, Samuel Steele, William Appleton. Owned by Leighton \& Co. Valued at $\$ 7,500$; insured for $\$ 6,500$.

Schooner BELLE BRANDON was wrecked on Long Island, near Mount Desert, Me., while on the passage to Grand Menan, N. B. Crew saved. Owned by Capt. Wm. H. Mackay. Valued at $\$ 3,800$; insured for $\$ 3,325$.

SchoonerDAY STAR, in the shore mackerel fishery, was lost in the gale of September 18th, with her crew of twelve men, viz.: Simon McKie, Master ; James R. Clarke, Charles 'Thompson, John McDonald, Harraden Reed, Andrew Ryan, Frank Anderson, Franeisco Constanta Scurpa, Francisco Joseph, William Thompson, Thomas Power, and a boy whose name is unknown. Owned by James Mansfield \& Sons. Valued at $\$ 4,000$; insured for $\$ 2,750$.

Schooner DAUNTLESS was lost on her passage to the Bay of St. Lawrence, in September, with her crew of twelve men, viz. : Jas. G. Craig, Master ; John La Pierre, Martin Costello, John Todd, Jr., George Todd, Daniel Herrick, Edward Smith, James Smith, James Welch, George Goodwin, and two others, names unknown. Owned by Sidney Friend \& Bro. Valued at $\$ 8,000$; insured for $\$ 7,000$.

Boat EQUITY, in the mackerel fishery, was wrecked at Spectacle Island, October 25th. Crew saved. Owned by Capt. Abraham Babson. Valued at $\$ 400$; insured for $\$ 362$.

Schooner WEATHER GAGE was lost on Georges, January 25th, with a crew of ten men, viz.: MIark Sweeney, Master; Abraham Bushy, Stephen Chisholm, William Powers, John Pitman, John McKenzic, Archic McNeil, Archibald McAlliston, Neil Macauley, John A. McKenzie. Owned by Maddocks \& Co. Valued at $\$ 5,000$; insured for $\$ 4,375$.

Schooner AUSTERLITZ was boarded by a heavy sea in the gale of March 13th, which left her in a sinking condition. Crew taken off by schooner Riverdale. Orned by McKenzie \& Knowlton. Valned at $\$ 3,700$; insured for $\$ 3,275$.

Schooner WILLIAMI F. POOL, lost on Georges, in March, with her crew of ten men, viz. : James Lunderkin, Master; William Troy, Henry Raymond, John Sullivan, James McLaughlin, Henry Peterson, 
Alexander MIcDonald, Peter Vaughn, and two others, names unknown. Orned by Sidney Friend \& Bro. Valued at 89,000 ; insured for $\$ 7,213$.

Schooner ALATAMAHA, lost on Georges, in Oetober, with her crew of ten men, viz.: William Brown, Master; Henry Gricr, Jas. Revilee, Benjamin Powers, William Geyer, Antone Norbury, Charles Terry, Charles IIamlin, and two others, names unknown. Owned by Capt. William Brown, and others. Valued at $\$ 6,000$; insured for $\$ 4,930$.

Schooner VIKING was lost in January, on her way to the Grand Banks. Had a crew of eleven men, viz. : William I. Rogers, Master; Edward Callalan, Patrick Frazier, Larry Frazier, August Frazier, Henry IIartford, William Parker, Jolın E. Reed, Lemuel S. Rogers, Dennis Sullivan, John Burke. Owned by Lemuel Friend \& Co. Valued at $\$ 7,800$; insured for $\$ 6,825$.

Schooner NOR'WESTER, of this port, sailed from New York for Para, in October, 1869, and was never heard fromagain. Commanded by Capt. John S. Foster, of this town, and had a crew of fire men, shipped in New York, whose names are unknown. Owned by Jolin Pew \& Son. Valued at $\$ 9,000$; insured for $\$ 3,500$.

Schooner JULIA PARSONS, Capt. Sturgis Center, was abandoned at sea, Novenber 20th, while on her passage from Surinam. Crew saved. Owned by Frank W. Homans. Valued at $\$ 8,000$; insured for $\$ 6,500$.

The following persons were lost in the Georges fishery during the year :

Antone Exos was lost overboard from schooner Pecrless, February 24 th.

Alvix Nickerson was lost overboard from schooner Rival, March 9th.

Matriew Gracia was lost overboard from schooner Eastern Queen, March 18th.

Fraxi Frazier was lost overboard from schooner Bridget Ann, Mrarch 19tll.

Tarzod J. V. Allex was lost orerboard from schooner Hightlyer, September 10th.

Williajr R. IIardy and Cimristian Cass were lost overboard from schooner Banvarl, September 4 th.

One of the crew of the Elisha IIolines, whose name is unknown, was lost overboard March 23ıl, while the vessel was leaving the barbor. 
John Carliste, of schooner Peter D. Smith, died on Georges, May 4th, of heart disease.

The following is a list of those lost on the Banks :

JosepII WARD and Francis LEe, of schooner John S. Tyler, were lost while visiting their trawls, May 15th.

Srmeon Clifford and Williani Bryant, of schooner Etta Gott, were lost in the same manner, in May.

James Scanlax and J. H. Ames, of schooner Mary G. Dennis, were upset in their dory and drowned while visiting their trawls, Oct. 12 th.

Albert Fadlk was lost overboard from schooner M. L. Wetherell, in October.

Michael Nolan was lost overboard from schooner George O. Hovey, October 18th.

Martin Quigly and John Kelly were run down in a fishing boat and drowned, off Eastern Point, May 26th.

JoHN RAKE was lost overboard fiom schooner Wildfire, October 19th.

\section{1.}

This was another terrible disastrous year to the fisheries, one hundred and forty lives and nineteen vessels being lost, and with the exception of 1862 , it resulted in the greatest sacrifice of life and property since the commencement of the business. Of the vessels, ten were lost on Georges, four in the Bank fishery, two in the shore fishery, one each in the herring fishery, Greenland halibut fishery, and freighting business.

Schooner HIAWATHA was lost on Georges, in February, with ten men, viz.: Byron Murphy, Master; John Glenn, William F. Powers, John McGratl, John Callahan, Michael Furlong, Martin Cowrey, James Goodwin, Stephen Green, Edward McRae. Owned by D. C. \& Horatio Babson. Valued at $\$ 7,800$; insured for $\$ 6,825$.

Schooner E. L. COOK was probably lost in the same gale with eleven men, viz.: Samuel H. Killham, Master; William H. Killham, John Cole, Lucius II. Cavis, Aaron Baker, Angus MreLeod, Martin Bakeman, Frank C. Welch, George IIall, Joseph Francis, Elisha Roberts. Owned by Perkins Brothers. Valued at 6,900; insured for $\$ 6,038$.

Schooner A. F. LINDBERG was lost in the gale of April 2d, with eleven men, viz.: Charles Boyson, Master; George Williams, Peter S. Miller, Henry Tweedy, Charles Simpson, Frederick Haudman, Joln Swinson, Alexander Ruden, Andrew Henderson, Andrew Christenton, 
Andrew Peterson. Owned by Daniel Sayward. Valued at $\$ 7,000$; insured for \$6,125.

Schooner SEAMAN'S PRIDE was lost April 2d, with ten men, viz.: William H. Thurston, Master; Joseph K. Balcim, Charles Joseph, John Graves, Charles Anderson, Alvah W. Turner, James Hanlon, Joshua Allen, Elbridge Goodwin, Gerthro Goodwin. Owned by Daniel Sayward. Valued at $\$ 4,000$; insured for $\$ 2,625$.

Schooner WILLIAM MURRAY was lost A pril 2d, with eleven men, viz.: Ezckiel S. Call, Master; Frank E. Call (son of the Master), Richard Carroll, Edward Hillier, Thomas Hasey, James Shehan, Mark Bray, William O'Brien, Samuel Stanley, Edward B. Curl, Alexander McConnell. Owned by Tarr Bros. Valued at $\$ 5,800$; insured for $\$ 5,075$.

Schooner B. K. HOUGH was lost April 2d, with ten men, viz.: Daniel Hillier, Master; Rufus Crosby, Alexander Carter, Michael McGraw, Willium Hopkins, Patrick Gray, John Swinson, Dennis Jewett, George Russell, John Merton. Orned by John Pew \& Son. Valued at $\$ 4,800$; insured for $\$ 4,200$.

Schooner SACHEM sank on Georges, in September. Crew saved. Owned by Capt. MIartin Nelson. Valued at $\$ 600$; insured for $\$ 525$.

Schooner MONTROSE was lost September 2d, with eight men, viz.: Alonzo Alley, Master; William Peterson, H. Steward, Alden Harris, Andrew Johnson, Charles Peterson, and two others, names unknown. Owned by Epes Sayward, Jr. Valued at $\$ 2,500$; insured for $\$ 2,100$.

Schooner FMPORIA was lost Sept. 2d, with nine men, viz.: Patrick Box, Master; Martin Whalen, Thomas Christopher, Michael Morrissey, Louis Turtua, Benjamin Hand, John Hand, John Porrers, - Charles Frazier. Orned by Joseph O. Procter. Valued at $\$ 4,700$; insured for $\$ 4,150$.

Schooner FITZ E. RIGGS was lost October 12th, with nine men, viz. : Laban E. Hiland, Master; Thomas Leary, Michael Fitzgeralcl, Alexander McKenzic, Robert Christopher, Charles Anson, John Welsh, Patrick Flynn, Thomas Foley. Owned by Maddocks \& Co. Valued at $\$ 3,800$; insured for $\$ 3,325$.

The following persons were lost overboard from the Georges llect during the year : -

Jouy Tucker was lost overboard from schooner J. J. Burns, February 11 th.

George Rackinas was lost overboard from Scbooner Rebecca Bartlett, Feb. 25 th. 
William McGuire was lost overboard from schooner William H. Thurston, March 24th.

JaMres Hont was lost overboard from schooner Amos Cutter, April 2d.

JoHn J. Collnss was lost overboard from schooner George O. Hovey, April 2d.

James Manning was lost overboard from schooner Adelia Hartwell, April 2 d.

Schooner EXCHANGE, lost at Cow Bay, in August, while on a trip to the Western Bank. Crew saved. Orned by Walen \& Allen. Valued at $\$ 1,300$; insured with outfit for $\$ 1,138$.

Schooner LIZZIE A. TARR, lost off Manitau, on the Labrador shore, October 15th. Crew saved. Owned by William C. Wonson. Valned at $\$ 7,300$; insured with outfit for $\$ 6,800$.

Schooner ELSINEUR, engaged in mackerel fishing in the Bay of St. Lawrence, went ashore at Argyle, in September, but was got off and afterwards burned on her passage home. Owned by Solomon Poole. Crew saved. Valued at $\$ 1,700$; insured for $\$ 1,487$.

Schooner RIVER QUEEN was lost with twelve men, while returning from a Greenland halibut trip, viz.: George Robinson, Master; Albert P. Gove, John Everson, Mark Shears, James Leavenson, Charles Brien, William McKenzie, and five others shipped at Halifax, names unknown. Owned by Rowe \& Jordan. Valued at $\$ 7,900$; insured for $\$ 6,912$.

Schooner SAMUEL E. SAWYER was lost April 21st, while on a herring voyage to the Magdalene Islands. Crew saved. Owned by Capt. James Cushing. Valued at $\$ 6,760$; insured for $\$ 5,915$.

Schooner OCEAN BRIDE, lost off Brace's Cove, Feb. 8th. Crew saved. Owned by John and Jesse McCloud. Valued at $\$ 1,800$; insured for $\$ 1,500$.

Boat ONWARD, of Lanesville, was burned on a shore fishing trip. Crew saved. Valued at $\$ 200$; uninsured.

Schooner ARAB, in the freighting business, was lost off Cape Cod, in April. Crew saved. Owned by Dodd, Tarr \& Co. Valued at $\$ 700$; insured for $\$ 550$, with an additional insurance of $\$ 1,000$, on cargo.

Schooner TWO-FORTY, lost in January, while on her homeward passage from the Grand Banks. Crew saved. Owned by Walen \& Allen. Valued at $\$ 5,000$; insured for $\$ 4,200$.

Schooner EDITH WONSON, lost on Western Bank, January 9th, with twelve men, viz.: Thomas Harvey, Master; Charles Forbes, Henry Walton, John F. Bennett, Robert Fardy, Llewellyn Walsh, 
Henry Leslie, James Ham, Frederic Newell, John Smith, William Atkins, William Hilerdsch. Owned by William C. Wonson. Valued at 88,500 ; insured with outht for 87,763 .

The following persons were lost in the Bank fisheries, most of them while visiting their trawls:

Joms Peterson was lost overboard from schooner Tivano, in January; Cart. Jonx Powers, from the Yo Semite, in January; Cart. Wy. Jefremer and Join Phales, from the Henry A. Johnson, in January; Stemen Nelsos and Chanles Axderson, from the Mary Carlisle, March 25th, and Laers Peterson from the same ressel in Norember; Geurge Searle and Nicholas Wilson, from the B. F. Somes, in Mry; Michael Kex and Tuomas MoKay, from the MI. L. Wetherell, in May; Frxeey MCFaddex, from the same in November; Hénry Beatos and Jons Stewart, from the Laura A. Burnham, in May ; Reubex Maro, from the Alaska, in May ; Tromas Hamlotos, from the George H. Pierson, Dec. 5th.

PATrick McGiswis and Jasper Quins in the Bay of St. Lawrence, from schooner Glenwood, in July.

Evdre Wharf, son of Capt. Eliphalet Wharf, was lost from schooner -Saralı C. Wharf, in the Bay of St. Lawrence, in September.

Josepu Plaimexta, was lost from schooner E. L. Rowe, off Dennisport, June 5th.

Jons Logue was drowned in the cabin of the Angie S. Friend, which was capsized in Boston Harbor, Feb. 5th. The vessel was afterwards raised and repaired.

\section{2.}

Sixty-three lives and twelve vessels were lost this year, as follows: four vessels in the Bank fishery, seven in the shore, and one Georgesman.

Schooner MESSENGER was lost on Western Bank, in January, with twelve men, viz.: Timothy Osier, Master; Thomas W. Gray, Peter Singer, John Flaberty, George Robinson, Levi Clark, William L. King, William C. Goodenow, Henry G. Blanchard, Albion P. Blake, Thomas Clark, Albert Hall. Owned by J. F. Wouson \& Co. Valued at $\$ 7,000$; insured for $\$ 6,625$.

Schooner SOUTHERN CROSS, engaged in the Grand Bank fishery, lost in the ice off Newfoundland, March 12th. Crew sared. Orined by Rowe \& Jordan. Valued at $\$ 7,000$; -insured for $\$ 6,125$.

Schooner FRANILLIN SNOW, lost on Grand Banks, with twelve men, in March, viz.: Charles P. Jewett, Master; Benjamin S. Jewett (his brother), Walter G. Jewett (their cousin) Horace P. 
Moore, Moses J. Moore, all of Westport, Me.; William Bushy, Alfred Lawson, Henry Olsen, George Jewers, Henry Lambert, Peter Conway, James G. Anderson. Owned by George Steele. Valued at $\$ 6,700$; insured for $\$ 5,926$.

Schooner WHITE EAGLE, lost on Grand Banks, in April, with twelve men, viz.: Nelson Goodwin, Master; Warren Goodwin and James Goodwin (brothers to the master), Samuel Goodwin and Asa Goodwin (brothers), Jedediah Goodwin, Simeon Goodwin, David Hines, all of Argyle, N. S.; Thomas Parsons, Leander M. Cook, of Rockport; James D. Burnham, Joseph Bowden. Owned by Rowe \& Jordan. Valued at $\$ 8,000$; insured for $\$ 7,125$.

The following persons were also lost in the Bank fisheries, the greater portion while visiting their trawls :

Jayes Downy and Richard Kelly, of Guysboro', N. S., were lost from schooner Mary Low, on Western Bank, in March.

William J. McKay, of this town, and Patrick O'Brien, of Newfoundland, from the George O. Hovey, March 12 th.

Stephen McCobb, of Friendship, Me., and Pierce Wotron, of this town, on Western Bank, April 3d, from the Ocean Belle.

Tromas McGowan, of Boston, and William Cuick, of La Have, N. S., on Grand Banks, March 21st, from the John Smith.

George T. Sanford, of Deer Isle, Me., and Alex. MoDonald, of Prince Edward Island, on Grand Banks, April 11th, from the M. L. Wetherell.

Ourver Johnson, of this town, of the Mary Carlisle, from a dory in Belle Harbor, N. F., June 3d.

William SAFford, of St. John's, N. B., from the William Parsons, 2d, on St. Peter's Bank, July 27th.

Reuben Prerce, of Boothbay, Me., from the Annie Linwood, on Western Bank, December 13th.

Schooner MATCHLESS, lost on Georges, in March, with ten men, viz.: Abraham Gilware, Master; David Goodro, John White, John Laseur, Frank Smith, Thomas Sampson, Alphonso Edwards, Thomas Anderson, Jaffrey White, James Tarr. Owned by Sidney Friend \& Bro. Valued at $\$ 7,200$; insured for $\$ 6,350$.

Schooner HERMAN E. POOL broke from her moorings and drifted out of the harbor, and was lost in a violent snow-storm, Feb. 3d. Owned by Capt. Samuel G. Pool and Joseph Friend. Valued at $\$ 5,700$; insured for $\$ 4,988$.

Schooner JOSEPHINE sprank aleak and sank off Portland, May 
25tll. Crew saved. Orrned by Peter Hanson. Valued at $\$ 2,000$; insured for $\$ 1,500$.

Schooner GEORGE W. CLIFFORD, sunk off IIarpswell; Me., July 2d. Crew saved. Owned by Jeremiah R. Cook. Valued at $\$ 1,200$; insured for $\$ 1,000$.

Scliooner TIVANO, lost on Green Island Ledge, off Portland, July 17th. Crew saved. Owned by Jolin F. Wonson \& Co. Valued at $\$ 1,500$; insured for $\$ 1,394$.

Schooner SIGNAL, run down and sunk off Matinicus, Aug. 30th. Crew saved. Owned by George Brown \& Co. Valued at $\$ 900$; insured for $\$ 813$.

Schooner WILLIAM WALWORTH, lost on 'Squam Bar, October 23d. Crew sared. Owned by the master, Capt. Owen Jones, and William Parsons, $2 d$ \& Co. Valued at $\$ 5,500$; insured for $\$ 4,875$.

Sehooner ADA L. HARRIS, lost on Nantucket Shoals, November 1st. Crew saved. Owned by Capt. John Blatehford. Valued at $\$ 2,700$; insured for $\$ 2,400$.

Caleb Coops, of this town, was lost on Georges, from the Edward Everett, March 2d.

James McLrtosin, of this town, and Charles Wells, of Manchester, were lost from the Ocennus, in the shore winter fishery, March 15 th.

Jasres S. Hetchrs, of Edgecomb, Me., lost from the General Grant, on the homeward passage from Newfoundland, January 17 th.

\section{3, TO JULY 1.}

Up to the above date, comprising the first six months of the year, there have been twelve vessels and forty-one lives lost. Six vessels were lost in the shore fishery, tro in the Newfoundland herring business, one in the Grand Manan, one Western Banker, one Georgesman, and one in the fruiting business.

Schooner ADDISON GILBERT, Capt. Jameson, engaged in the shore winter fishery, was run into while on her way out of Portsmonth Harbor, January 6th, by sloop M. M. Hamilton, of Portland, and sunk. The crew had barely time to get on board the sloop, saving only what they had on. The ressel was a total loss. Owned by David Low \& Co. Valned at $\$ 2,600$; insured for $\$ 2,275$.

Schooner FRANKLIN A., Capt. David Melanson, was run down by schooner E. B. Phillips, on the evening of January 17th, off Falkland Island, Long Island Sound. The Phillips struck the Franklin A. nearly amidships, carrying away both masts, and cutting through 
the hull, and she sank almost immodiately. Capt. Melanson, and the mate, Roderick Dyer, were knocked overboard by the shock of the colliding vessels, and were in the water some time before they were rescued, narrowly escaping a watery grave. Owned by John F. Wonson \& Co., and the captain. Valued at $\$ 6,000$; insured for $\$ 5,500$.

Schooner GEORGE STEELE, in the fruiting business, was lost in the gale of January 13th, sixty miles from Baracoa. Crew saved. Owned by George Steele. Valued at $\$ 7,300$; insured for $\$ 6,300$.

Schooner MIARY T. YOUNG, in the shore winter fislıery, went ashore February 1st, three miles below Race Point, ancl became a total loss. Crew saved. Valued at $\$ 1,200$; insured for $\$ 1,000$.

Schooner THORWALDSEN left Newfoundland for Gloucester, Feb. 18th, with a cargo of frozen herring, and never reached port. Had a crew of seven men, as follows: George W. Phillips, Master; William S. Callahan, mate ; John Gorratt, Ronald McEachren, John Crittenden, Donald McDonald, William Smith. Owned by Capt. James R. Hamilton and others. Valued at $\$ 7,800$; insured for $\$ 6,825$.

Boat GARIBALDI was lost in Ipswich Bay, March 11th. Crew saved. Owned by George W. Morgan and Levi Lane, of Lanesville. Valued at $\$ 300$; no insurance.

Schooner J. H. ORNE was lost on Georges, in March. Crew of eleven men, viz. : Matthew A. Nickerson, Master ; Frank Rose, John Berry; Frank M. Silva, Manuel Rogers, John Williams, Manuel Roberts, E. F. Terry, Manuel.T. Morris, Joseph Morris, Manuel Veader. Owned by Samuel Lane \& Brother. Valued at $\$ 6,500$; insured for $\$ 5,500$.

Boat O'CONNELL, engaged in the shore fishery, was lost near the Powder Hole, Cape Cod, May 14th. Crew saved. Owned and commanded by Capt. Thomas Sullivan. Valued at $\$ 800$; no insurance.

Schooner WILLIAM J. DALE sailed for the Bay of Islands, New. foundland, in November, and started for home, but never reached port. Had a crew of nine men, viz. : Murdock MIcNeil, Master; Peter Flynn, James Scott, John Conway, Adalbert Gilley, James Cook, James Lawler, and two men, names unknown. Valued at $\$ 5,800$, on which is claimed an insurance of $\$ 5,500$.

Schooner LAURA A. BURNHAM, in the Western Bank fishery, was lost on Sable Island, May 27tl. Crew saved. Owned by James Mansfield \& Son. Valued with her outfit at $\$ 7,500$; insured for $\$ 6,488$.

Schooner BELVIDERE, shore mackercling, lost on Benton's reef 
near Newport, R. I., June 4th. Crew sared. Owned by Danlel Sayward. Valued with outfit at $\$ 2,300$; insured for $\$ 2,075$.

Scliooner FAIPIRE STATE, Capt. Stephen Smith, in the sliore mackerel tishery, went ashore at Cape Porpoise, June 30th, and became a total loss. Crew saved. Orned by the master, and others. Valued with her outrit at $\$ 4,000$; insured for $\$ 3,563$.

Tho following persons wero lost in the Bank fisheries, the greater portion of them meeting their death while visiting their tranls:

Axтnoxy $\Lambda$ unoe was lost from schooner Elisha Crowell, on Weztern Bank, January 22d; Micinal Caretos, from the Aaron BurnLam, 2d, March 22d, while on the passage to Grand Baulss; $\Lambda$ renr bald Beaton and Bexu. Carpexter, from the Sarah P. Ayer, Marcl 14th; Leveretr Lelaxd and Charles O. Dale, from the Tragabigzanda, March 24th ; EDward White, from the IIattie S. Clark, May 18th; Patrick Murpiy aud Charles MePuersox, from the Ruth Grores, May 2d; Wy. W. Colby and Charles M. Greenleaf, from the Peter D. Smitl, June 11th.

Tulousas Olevrson, one of the crew of the Esther Ward, cliel very suddenly, of heart complaint, on Georges, June 13th. IIe was baiting his hook at the time, when he dropperl on deck and allnost immediately expired.

Jayes Fonax, of the Water Spirit, was drownel at Port Dover, N. S., May 28th, by the capsizing of a boat.

Capr. Dexcan Grast, of the Finance, was lost on Georges, February 18 th.

The foregoing losses sbow an aggregate of 1265 lives and 280 vessels lost during the past 4:2 1-2 years. Of this number, 93 ressels and 708 lives were lost in the Georges fishery; 10 ressels and 209 lives in the Grand and Western Dank fisheries; 56 ressels and 107 lives in the shore cod and mackerel fisheries; 48 ressels and 93 lives in the Bay of St. Lawrence mackerel fishery; 19 vessels and 68 lires in the Newfoundland herring fishery; 34 ressels and 65 lives in the freighting business; 2 vessels in the Grand Manan herring fishery; 1 ressel and 12 lives in the Greenland halibut fishery; 6 ressels burnt by pirate Tacony; 1 pilot boat lost in the harbor. Of the 280 vessels lost, the crews of 147 (a little more than half) were sared. The loss of life and property on Georges is upwards of one half the entire loss. The total value of the ressels lost is $\$ 1,145,500$, on which there was an insurance of $\$ 339,525$, mostly in the local oflees. 
In addition to the above are the partial losses, losses of cables, anchors, ctc., which cannot be reckoned less than $\$ 150,000$, making the total loss, $\$ 1,295,500$.

As no record of the number of widows and orphans made by these losses was kept previous to 1858 , it is impossible to get at the correct number, but taking an average of the past twelve years, it would give ten widows and twenty fatherless children yearly, or a total of 422 widows and 844 children. The losses average 28 lives and 6 vessels yearly.

Errata. - In the heading of this ehapter, the number of lives lost is stated 1251 - num. ber of ressels, 281. After the first pages were printed, additional losses of life were aseertained, which increased the total number to 1265 , as shown by the table on the next page. One schooner, not owned here, has also been taken from the list, making the correct number of ressels lost, 280 , as per table.

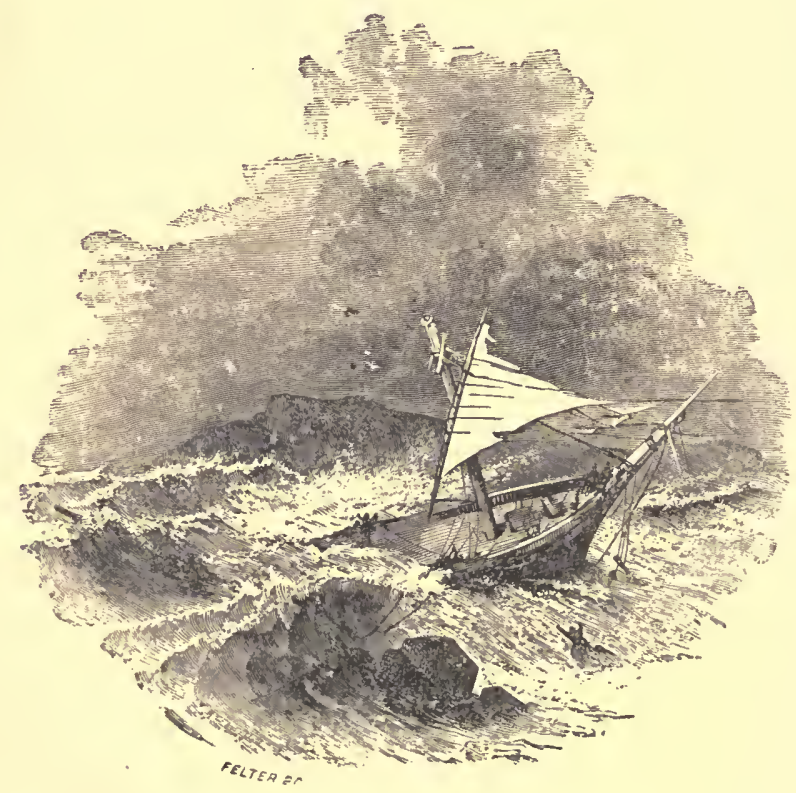


TABLE OF RECAPITULATION.

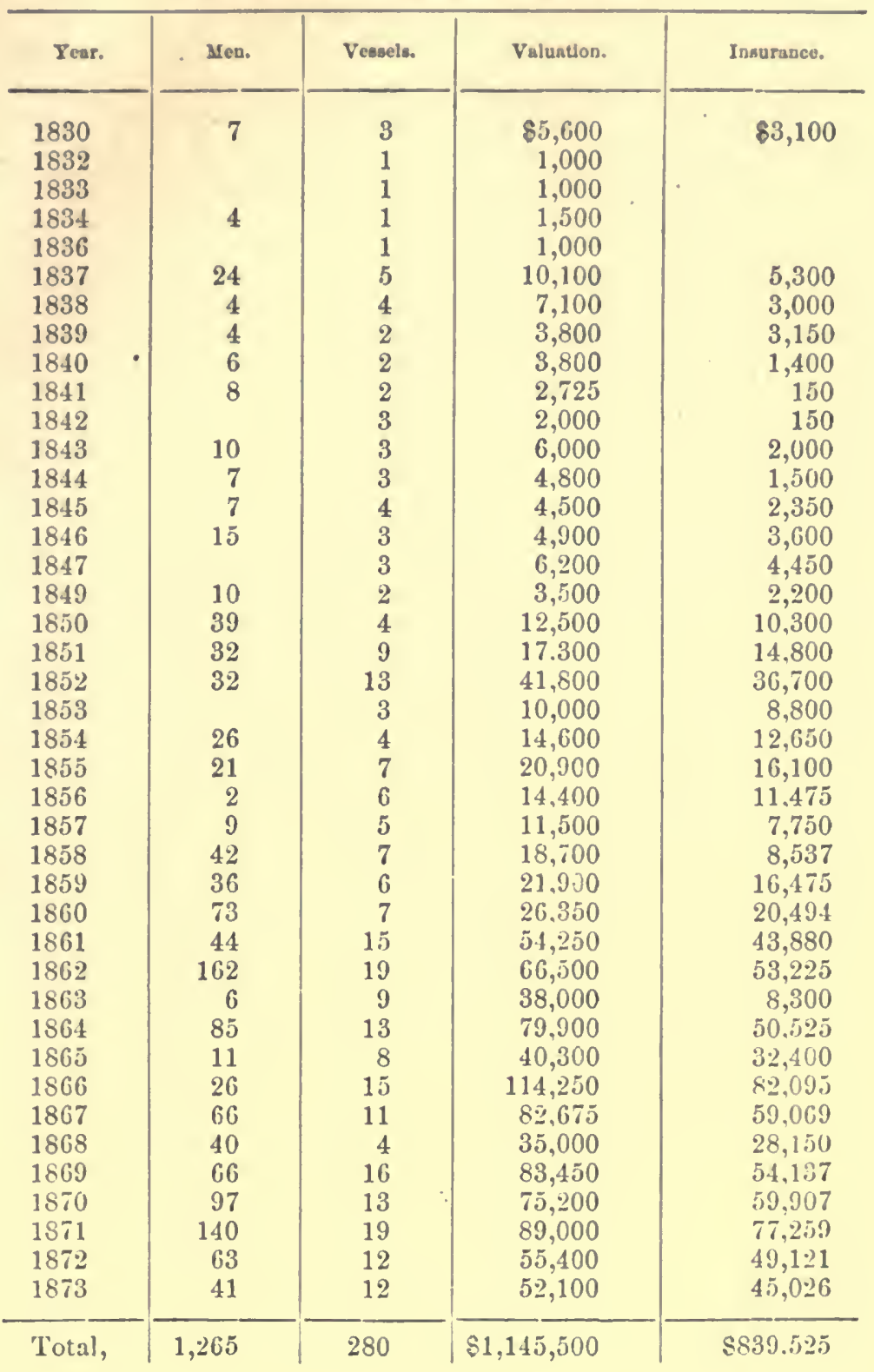




\section{On Georgés in the Terrible Gale of February 24th, 1862. The experience of one who was there for the first and the last time.}

[Among the crew of one of the Georgesmen which escaped the terrible perils of the gale of February 24th, 1862, was a young man from one of our inland cities, who had made several trips mackereling, in the summer months, where he had heard the "veterans" talk of the perils of the Georges fishery. These stories, told with the gusto. of first-class yarn spinners, kindled within him a strong desire to go on one of these trips, which he did, and as it happened, he got an experience which will last him a life-time. We gleaned from him the following narrative of that terrible event, which we publish almost verbatim.]

The winter of 1862 found me out of employment, and I determined to gratify my long pent-up inclination of going to Georges. It was early in February. The weather had been extremely mild for the scason, and there were busy times at the wharves in Gloucester, fitting away the vessels, some of which had already sailed, and many were nearly ready.

Upon going to the fitting-out store of Messrs. - - I was cordially received. They were surprised to learn that $I$ wanted to go to Georges, and endeavored to dissuade me from my purpose; but all of no avail, and as they had a vessel which would be ready to sail in a day or two, told me I could have a chance in her. Procnring the necessary additions to my outfit, I entered heartily into the work of getting our craft in readiness. The ice-house in the hold was filled with the crystal blocks, the cable and anchors overhauled, gurry-pens placed in position, bate of fresh herring packed in the ice, provisions taken care of, and the vessel put in a tant and strong condition.

On the morning of February 14th, we started, and, in a glorions run of twenty-four hours, sighted the fleet on the Banks - nearly a hundred sail, riding at their anchors, half a mile, and in some instances, a mile apart. It was a pretty sight, and the fine, clear weather, rendered it highly enjoyable. We could distinctly see the men at 
the rail pulling in fish, rapidly as hands and arms could move. Soon our position was selected, anchor down, and the crew busy getting rearly to try their luck.

The cold, to one of my constitution, was intense, and pierced into the very marrow of my bones, although thickly elothecl. But this deep sea fishing was so exciting that $\mathrm{I}$ stood at the rail sometimes u full hour, without clanging my position, pulling in tho big codish, and occasionally a halibut. It was a moment of supreme gratification when I hauled in my first fish of the latter species, and saw him floating alongside with the look securely fastened in his mouth. One of the crew helped me to gaff him over the rail, and I felt myself master of the situstion. Our steward, a Portugnese, was a clever fellow, and, in honor of my first halibut, brought me a mugful of hot coffec, and a pancalic with plums in it, called by the fishermen a "jocflogger." Pulling in these big fish from so many fathoms down, against a strong tille, was work I was not accustomed to, and glad enough was I, after partaling of a bearty supper, to turn into my bunk, and be lulled to sleep by the tossing of the billows.

The erew were a jolly set, and for scveral days the weatlier was fine, the fish abundant, and the fun immense. We had changed our berth twice, each time drawing nearer to the body of the flect, and each time found the fish more plentiful. I began to think that the Georges fishery, after all, was not so bad as it had been represented, although it used to fret ine exceclingly to see so many of the ressels lying so ncar together, knowing full well that, in case of a sudden storm and they dragged their anehors, chafed off their cables and went adrift, collision would be incritable. But there being no apparent danger, I dismissed the thought in keeping busy.

We now liat more than half a fare, and the skipper remarked, one afternoon, as he lit bis pipe :-

"Boys, if our lick holds on, by another week we'll think of putting our craft on the homeward track."

This was cheering, and we finished up the day with a good catch. At sundown, there was quite a sudden clange in the weatler. The clouds massed, and the rising wind made the sca rough. All signs indicated an approaching storm. It was a wild-looking night; the ressels tossed up and down like cockle-shells. At eight o'clock the skipper began to get uneasy. He kept looking up at the sky, and then glaneed along the horizon. Ben, my clum, whispered to me:-

" Depend on it, we're going to have a tough one ont of this, and I shouldn't wonder if you had a chance to sce more o' Georges than 
you'll ever want to see ag'in. I've been with the old man half-a-dozen years, and when I see him walkin' and lookin' that way, I make up my mind that som'thin's goin' to happen."

By this time, the sky had grown inky-black, the wind had reered to the northeast, and was increasing in violence. It began to snow - moderately at first, then more fiereely fell the white flakes. The skipper went forward and examined the cable, then gave orders to pay out some ten fathoms or more, which was done. Our lights in the rigging had been lit since sundown, and all about us were the lights of the fleet, looking so prettily, as they danced up and down with the motion of the vessel. The skipper, upon being asked what he thought, replied : -

"We'll have a tough time 'tween now and morning, and the watch must keep a sharp look-out for drifting vessels. If the rest of yon * want to take a nap, do it now, as there won't be much sleeping a couple of hours from now."

All hands except the wateh, went below at about half-past eight o'clock. I could not remain there, but kept going on deck. It was something new and terrible to me, and as I was well wrapped, I did not suffer much from the wet and cold. But I did feel anxious, and I would have given all I possessed, were I safely at home. But wishing was of no avail - here I was, and I must take my chanee with the rest. We can die but once, thought $I$, and $I$ began to have serious thoughts. Not that I was afraid of death - no, that was not the feeling - but there was one at home whom I wanted to see, and, holding her hand in mine, I should have been better reconciled. But perhaps it is as rell not to tell all my thoughts at that fearful time. We bave singular faneies in hours of danger.

It was now about eleven o'clock. The wind had risen fearfully, the snow came down spitefully, and the sea rose higher than I had ever supposed it possible for it to rise, and was covered with snowy caps of foam. The sensation of being tossed up and down so violently, together with the darkness and the storm, werc not pleasing, and it seemed to me, that every plunge the vessel made would be her last.

As midnight drew near the gale inereased fearfully. I had never experienced anything so terrific before, and the stories which were told on board the mackerel-catcher now assumed a more truthful aspect. How the winds shricked through the eordage, and the waves leaped, seemingly impatient to add us to the many victims which have been swallowed up on this treacherous spot! My shipmates 
showed no signs of fear; they were now all on deck, and the skipper was keeping a sharp lookout. Ben was also on the alert, and had placed a hatchet near the windluss, to be in reacliness should it be deemed neeessary to cut our cable. $\Lambda$ s he came near where $I$ was standing, be very coolly remarked "that if we clid not break adrift ourselves, or some other ressel didn't run into us, he thought we might ride it out." To me it seemed an utter impossibility for any ressel to stand such a gale, but I said nothing. The great danger to be apprehended was from collision, as in case that either ourselves or some other of the llect lost their anclior or parted their cable, away they would go with fearful speed; then if they struck another craft, goou-bye to both of them - there was not the slightest hope for either.

The darkness was impenetrable, and a moro dismal night I never passel. How I louged for morning to dawn. Onee in a while the storm would lull for a little time, and the snow did not fall so thickly; then we could see some of the lights of the fleet; but this was not often. We knew the situation ere the storm came on, but now we must wait till dayligltt. 'The hours dragged heavily along - anxlous lours they were. They are indelibly impressed on my memory, and will not be effaced until death claims me. During the night, a large ressel passed quite near us. We conld see her lights, also her spars and sails, as she sped swiftly along on the wings of the storm. Glad enough were we, to have her pass us, and I trembied at the thought of our fate, had she struck our little eraft. When I learned of the terrible disaster of the gale, I came to the conclusion that this vessel was the cause of some portion of it.

At length the east began to lighten; morning was coming. What a relief it was when the day dawned! Our clanger was not over, for the gale still continued, but there was a comfort which the light bronght, that did me good. The fearful darkness of the night, and that terrible uncertainty was relieved, as we could now see our position, and could now the better guard against the threatening dangers. Our vigilance was not relaxed. We hall something to eat, and then kept up our watching, for the stom still continued its fury. Somewhere about nine o'clock, the skipper sang out, "There's a ressel adrift right ahead of us! stand by with your hatchet, but clon't cut till you hear the word!"

Ben was there at his post. II could be trusted at such at time, and would await orders - this all on board lnew full well.

All ey"es were 
now bent on the drifting craft. On she came! It was a fearful moment to me, and it was evident that the men - some of whom had followed Georges fishing for ten seasons, thought there was danger now - but they were not afraid. There they stood, determined to do their best for their lives. I knew I should share the same fate with them, and there was some consolation eren in this. The drifting vessel was coming directly for us; a moment more, and the signal to ent must be given! With the swiftness of a gull she passed by, so near that I could have leaped aboard, just clearing us, and we were saved from that danger, thank God! The hopeless, terror-stricken faces of the crew we saw but a moment, as they went on to eertain cieath. We watched the doomed craft, as she sped on her course. She struck one of the fleet, a short distance astern, and we satw the waters close over both ressels, almost instantly, and as we gazed, they both disappeared. Then we knew that two vessels of the fleet would never again return to port.

We had little time to think of others, as we began to drag our anchors, and yaw about too much for safety. This was dangerous in the extreme, for if the anchors did not take hold again, we must cut the eables, and, once adrift, we knew our fate. Fortunately, the anchors found holding ground, and we rode again in safety.

All through the day we watched. Twice wats our safety endangered by vessels adrift, but they. went clear. Te were saved! At sundown the gale modcrated, but we knew that many a poor fellow who had left Gloucester full of hope, would never more return; that many a wife would never again see her husband, and mothers and brothers and sisters would have cause to remember the terrible gale which had swept so fearfully over the Georges.

I was on nettles all next day, as I thought the skipper would immediately start for home. But judge of my surprise to see the men coolly get their lines in readiness for fishing, just as though there had been no storm, no danger or peril but a few hours ago. This was indeed intensely practical. They smoked and talked of getting a fare with so much coolness, that it really seemed terrible to me. "Supposing we should catch another gale - what tien?" I received for a reply, that "they had come to get a trip of" fish; I, to see how I liked Georges." We fished through the weck, had good luck, and it was a happy moment when the skipper said, "Get the anchor; we'll turn her nose homewarcl." Eastern Point Light, when first sighted, looked cheering and friendly. As we passed in by the Fort, there was a crowd of people, and as they saw our vessel's name, there 
was rejoicing. Sereral came on board asking if we had seen such a vessel since the gale. The town was in commotion. Such anxiety I hope never again to witness.

When the ressel carro alongside the wharf, I put my luggage out, and concluded not to repeat the experiment of making a trip to Georges in midwinter. When I got home, they told me I had grown much older in the few weeks of my absence. What I experienced during that night and day of storm was enough to make any one, especially a green hand, grow old. I have no wish to try it again. If the reader wishes a similar experience, perhaps it would be well for him to take a trip, but I advise all such to make their wills ero they leave port. .

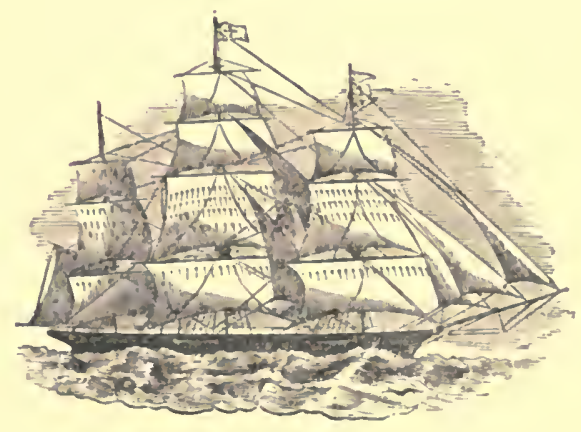




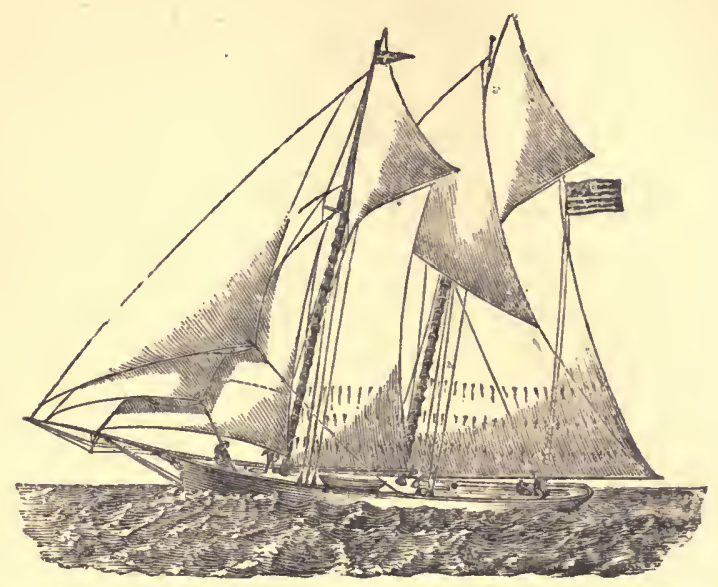

\section{The Mackerel Fishery-Giving an Account of its Commencement and Progress, with Statistics of the Catch for the past Thirteen Years.}

This branch of the fisheries, which has now assumed such magnitude, has quite an interesting history, which we have gleaned from parties who were directly interested, and know whereof they affirm.

It was first prosecuted by the small boats, about the year 1800 . The mackerel were caught mostly on the inner Bank, and carried fresh to Boston market through the summer. Only the largest were saved, and these were sold for five or six cents apiece, and sometimes as high as ten cents. Each boat was ballasted with pebbles; on this were placed hogshead tubs, each having a hole with a plug in it. These tubs were filled with salt water, and as soon as the mackerel were dressed, they were put into the tubs, and the water changed every hour by drawing the plugs and allowing it to run off, until suffcient were caught to start for market, the changing of the water continuing, until the boat arrived abore the Castle, where it is said the water loses its coolness. The great object after catching the mackerel was to get them to market before daylight, in order to have the cool of the morning to sell them in. If a boat with three men and two boys stocked fifty dollars a week, it was considered satisfactory. 
Trailing was ono of the means used to catch mackerel in tho olden time, and one of our old fishermen informs us that when a larl, he distinctly remembers of being out in Boston Bay, one day, in a boat with his father, when he saw a vessel which looked very strangely to his young eyes, and, boy-like, he asked his father what sort of craft it was.

"That's a trailer, my boy, and we'll speak with him," was the reply.

They sailed quite near, and they observed that the ressel bad outriggers of long poles on each side, commencing forward at about serenteen feet, and tapering off to fire feet aft. $\Lambda t$ the ends, lines were fastened, about trenty fathoms long, with a sinker of four pounds, and hook below. To each of these lines were attached a bridle, reaching to the side of the ressel, where the fishermen stood to feel the bites. This particular vessel was from Hingham, and had been out four weeks without receiving even a bite, and the skipper said he was going to gire it up and go home.

In 1812 a large school of Spanish mackerel visited this Bay, and so plenty and numerous were they, that they would bite readily at the bare hook, and seize upon small bits of line hanging from the vessel. Standing-room boats were then mostly in use, of from fifteen to twenty tons. These rooms held from fifteen to twenty barrels, and the ererrs rould cateh them full in a few hours. Mr. Timothy Rogers, at Rowc's Bank, bought most of these mackerel, fresh, after being dressed, at two cents per pound, salting them in his buildings, and the business, which lasted two months, was a lively one. These mackerel did not continue on this coast but a fer years, and have now almost entirely disappeared. There were a few eauglit, with the other mackerel, as late as 1825 , since which time it is very rare to sec one during the entire season.

The present mode of catching mackerel by drifting and tolling with bait, did not come into general use until after 1812. The gear for catching, previous to that, was a white hempen bob line, as it was called, and the style of fishing was termed "bobbing" mackercl. These lines were some seren fathoms in length, with a leaten sinker two inches long, and shaped like a thin pea-pod. At one end was a ganging about a foot long, for the hook. Every few minutes off would go the hook, and extra hooks were always in readiness to replace those lost. This mode continued until the year 1816, when Abraham Lurvey, of Pigeon Cove, discovered a method of running lead around the hooks, and which were afterward called jigs. This 
he kept secret for many months. The hooks then in use were nearly as large as the haddock hooks of to-day. The small lines and fly lines, did not come into use until about 1823. About this time the gaff was introduced, and was abandoned after being used some ten year's.

In the commencement of the mackerel fishery, the crews, with some few exceptions, continued through the entire season. But one settlement was made, the men, who were classed as sharesman, all sharing equal, the mackerel being put together in common stock.

Bait mills were not used until the year 1820, or thereabouts. Previous to this, the bait was ground up by the fishermen under the heels of their heavy boots ; subsequently it was pounded with mallets, then came the chopping on a block with hatchets, which was considered quite an improvement, and was done during the watch at night. The bait mill, however, proved the thing, and came into general use soon after its introduction.

In the summer of 1818, Capt. Simeon Burnham made a trip in the schooner President, to Cashe's, for the purpose of catching mackerel to salt. This, so far as we can learn, was the first trip for the purpose of catching mackerel to salt, ever made from this port; consequently to Capt. Burnham belongs the honor of being the pioneer in this branch of the fisheries. It was considered quite an important erent at the time, so much so that Capt. Benjamin Tarr was hired to go as navigator. Seventy barrels were caught on this trip, and they were packed in Boston. Two years after, this branch began to increase, and in 1821, several other jiggers were added to the flect. They carried six hands and were absent about a week. The jiggers were stowed with butts and wash-barrels, and no mackerel were headed up on board, until about 1820. In 1821, Samuel Wonson, Elisha M. Oakes, Robert Marston, Simeon Burnham, Samuel Brown, Nathanicl Blatchford, John Wonson, George Wonson, James Merchant, Epes Merchant, were the skippers of the jiggers, which comprised the chief part of the mackerel fleet. These jiggers ranged in tonnage from trrenty-seven to forty-five tons. Prior to 1818 , there were but few mackerel packed in Gloucester, that part of the business being mostly done in Boston. Moses Gilbert was the only inspector in town until 1828, and his accommodations were quite limited. At this date several other inspectors were appointed, and the mackerel fishery began to assume quite a business importance.

In the year 1822, Capt. William MIarshall caught a few mackerel on Georges, which were the first, so far as we can așcertain, ever caught 
there by a Cape $\Lambda \mathrm{n} n$ skipper. Maclierel liare been cauglit there every year since, more or less, and rank in quality among the best.

The first trip to the Bay of St. Lawrence for mackerel, fiom this port, was marle in 188n, hy Capt. Charles P. Wood, in the Mariner. She was absent but four weeks, and came in full of large fat urack. crel. This created quite an excitement among the fishermen, and the next, season the Bay fishing commenced in good earnest. 'The ressels at first made but one trip, and finished up their season's work on this shore. Two hundred and fifty barrels was considered a gool trip for a ressel of forty or fifty tons. $\Lambda$ s soon as the business was found to be profitable, vessels of a larger class were added to the lleet, and it las gradually inereased from year to year, until the present time.

The seasons of 1825 and 1831 were the greatest known for mackcrel, up to this rlate. Vessels not over fifty tons, lancled upwards of thirtcen lundred barrels, averaging through the neet about eight hundred. Maelicrel continued in Boston Bay, near the land, in the year 1825, until the fourth day of December, the erew of schooner Frances Elizabeth having caught twelve wash-barrels on that clay. The eatch was not so large as in ' 31 , to each vessel, but the aggregate was much larger, and the mackerel of a better quality. These fish were so plenty that the fishermen deroted the day to catching, and the greater portion of the night to landing and clressing, and rere completely worn out with their arduous labors. One morning duling the first week in December, while the lect were some ten miles off Eastern Point, the mackerel failed to come to the surfuce, after the usual throwing of bait. 'This was a pretty sure sign that they had gone, and the fishermen, whose sore hands and tired bodíes bore evidence of the work they had accomplished in mackerel eatching, were beartily glad, that at last the fisi had taken themselves off, and many of the lleet hoisted their Alags as a token of their rejoicing over the erent of the mackercls' departure. 'The price of mackerel this ycar was $\$ 5.500$ for 1's; $\$ 3.50$ for 2's; $\$ 2.50$ for 3 's, ancl out of this, $\$ 1.25$ ras paid for packing.

From the clozen jiggers which composed the greater portion of the maclierel Alect of 1821, we have to-clay, fifty-two years later, a flect of some tro bundrell elipper sclioouers, perfect in all their appointments, engaged in this branch of the fisheries. The hook and line has giren place, to a great extent, to scines, and the rapiciity which a scincr's crew will surround a school and make a haul forms a seene of the most intense excitement. It oftentimes happens that they are unable 
to take care of their haul, and in order to make the most of the catch, some other vessel is signalized, and in consideration of giving a certain percentage of what they may get from the nets, are allowed to help themselves.

Mackerel catching by the hook is lively sport. The school is seen a short distance ahead, bait is thrown to toll them alongside, then over go the lines, and hands and arms are busy in pulling them in and slatting them off-their jaws being so tender that it is not necessary to unfasten the hook. A peculiar sort of a jerk, soon acquired, does this, and then up with another, and so on, as long as the school can be kept alongside. Then follows the dressing, and by the time this is accomplished, one is tired enough to turn in and enjoy a good solid dose of " tired nature's sweet restorer, balmy sleep."

Below is given the statistics of the catch of mackerel from the port of Gloucester for the past thirteen years :

1860.-37,407 1-2 No. 1's; 42,659 7-8 No. 2's; 17,108 No. 3's; 816 5-8 No. 4's ; making a total of 97,992 barrels, for the year.

1861.-37,995 3-8 No. 1's ; 45,533 1-2 No. 2's ; 6,707 1-4 No. 5's ; 279 3-4 No. 4's ; making a total of 90,515 7-8 barrels.

1862.-53,569 7-8 No. 1's ; 33,115 3-8 No. 2's ; 29,364 3-8 No. 3's ; 188 1-4 No. 4's ; making a total of 116,237 7-8 barrels.

1863.-54,855 5-8 No. 1's ; 71,983 5-8 No. 2's ; 26,921 1-4 No. 3's ; 132 No. 4's ; making a total of 153,8921 -2 barrels.

1864.-68,061 1-2 No. 1's; 73,002 No. 2's; 13,866 3-4 No. 3's ; 8 1-2 No. 4's ; making a total of $154,9383-8$ barrels.

1865._-99,174 3-8 No. 1's ; 28,378 1-2 No. 2's ; 13,995 1-2 No. 3's ; 28 No. 4's ; making a total of $141,5753-4$ barrels.

1866.-86,245 No. 1's; 13,630 7-8 No. 2's ; 12,978 No. 3's ; 2 1-2 No. 4's ; making a total of $112,8563-8$ barrels.

1867.-78,062 1-8 No. 1's; 17,328 1-8 No. 2's ; 8,507 1-8 No. 3's; 20 1-2 No. 4's ; making a total of 103,917 1-2 barrels.

1868.-50,652 1-2 No. 1's ; 14,209 1-8 No. 2's ; 10,495 1-2 No. 3's; 160 No. 4's ; making a total of 75,517 1-8 barrels.

1869.-37,123 1-4 No. 1's ; 36,595 1-2 No. 2's ; 18,495 2-3 No. 3's ; making a total of $92,2145-8$ barrels.

1870.-32,089 3-4 Nó. 1's ; 82,935 3-4 No. 2's ; 14,564 5-8 No. 3's; 5 No. 4's ; making a total of $129,5951-4$ barrcls.

1871.-49,144 5-8 No. 1's ; 36,880 7-8 No. 2's ; 20,592 3-4 No. 3's ; 30 1-2 No. 4's ; making a total of $107,0083-4$ barrels.

1872. - 34,013 3-4 No. 1's; 20,403 No. 2's ; 12,959 No. 3's ; 23 No. 4's ; making a total of 67,395 7-8 barrels. 


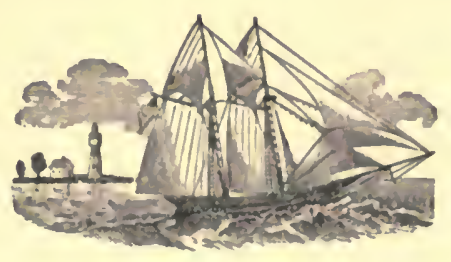

\section{The Haddock, Pollock, Cod and Halibut Fisheries, giving an account of the First Trips to Georges for Codfish.}

An important feature in the Spring fishing, from 1812 to 1817, was the haddock market fishery, which was pursued by the fishing boats. The fish were very abundant in the vicinity of Nahant, and were marketed at Charlestown, where the alewives used for bait could be obtained. These were caught at Medford. The fishery eommenced from the first of March and continued until the latter part of April. At this date herring came into the bay, and the Spring codfishing began.

Tro-thirds of the boats engaged in the fisheries at this time belonged to Sandy Bay, (now Rockport,) and at the approach of storms would come round into this harbor for shelter, mooring in fleets, fast ened together, and in numers not less than from thirty to forty sail. The skippers and crews would walk home, leaving the boats in the eare of a sufficient number to look out for them until the storm was over.

During the month of May, 1821, Capts. Simeon Burnham, in the President, George Friend, in the Columbus, Elisha Brown, in the Independence, and Samuel Brown, in the Volant, sailed for the Bay of St. Lawrence, on the first codfishing voyage to that locality from this port, arriving home on the third of July, with full fares. At that time nothing was known of kecping fish salted in butts through tho summer, and the facilities for curing were very poor, consequently they 
were badly burned in drying, and did not bring in the New York market hardly two dollars a quintal.

During the month of June, while the four above mentioned were in the Bay of St. Lawrence for codfish, and there being a scarcity of fish in Boston Bay, the other three, viz.: Capts. Samuel Wonson, of the Three Sisters, Elisha M. Oakes, of the Eight Brothers, and Robert Marston, of the Two Friends, held a consultation, and resolved to run the risk of making a trip to Georges Bank. At this time, $(1821$,$) it was related as a positive fact, that if vessels an-$ chored on Georges, the current would surely run them under. The three vessels sailed, keeping close company. They dicl not dare to anchor at first, but drifted about and caught a fer fish. Finally one of the skippers proposed to run the risk and anchor one of the vessels. This, after some discussion on the part of all hands, was agreed upon, and two extra men were put on board the vessel, as a reinforcement, to assist in getting the anchor quickly in case of any difficulty. All preparations being completed, the anchor was let go, and shortly catches the bottom, then:spin goes the cable around the windlass. "Now, check her a little," was the order. Soon it got a good hold, and the vessel started in apparent motion through the water, at about three knots an hour. In the mean time the other two vessels, having taken the current, are fast leaving the anchored craft, and those on board began to get alarmed. The order to heave up anchor was soon given, and after an hour-and-a-half's work this feat was accomplished. Before dark a little breeze sprang up, and the vessels all met again and started for lome. Thus ended the first codfishing trip to Georges. These facts were obtained from parties who heard the men tell their story on their arrival home, and may be relied upon as a correct account of the first codfishing trip to Georges by Gloucester vessels ; as we fail to find that any other vessels were there previous for this purpose, these three must have the credit of being the pioneers of the business.

From 1812 to 1820 the boats were mostly employed in Spring, in shore fishing, bringing in the fish fresh and dressing them from the boats on the beach. After the Spring fishing, the vessels would go on the coast of Maine, halking. This fishery lasted only a few weeks. In Summer, tending Boston market with mackerel caught in Boston Bay, and in the Fall months in the pollock fishery, catching their bait in seines at Little Good Harbor Beach. This pollock school was a great feature in the fishing business, proving the turning point in the year, and their appearance was looked forward to by the fish- 
ermen with considerable anxiety. Their scarcity or abundance decided the purchasing of many articles of comfort in the fisherman's family, and therefore all were interested in having a good pollock catcl to wind up with.

Mention has been mado that the fish wero landed on the beaches to be dressed. This was done from necessity, as thero were no wharves then in town, from 1812 to 1820 , below William Pearce \& Son's wharf, except the remains of Rogers', at Rorre's bank, which had only one side at which a small ressel could lic, and Friend's wharf, a cob of about $50 \times 20$ feet, the remains of a pier of about $30 \times 15$ feet, at what is now Deacon Parker's wharf, and a small landing place at Capt. Daniel Sayward's. Beyond, on the Point side, not a landing place of any description was to be seen. In the Harbor Cove, at the Fort, was the Parsons wharf, now Poole's. On the beach there, was only Moses Gilbert's. No additional wharves were built on the beach until after 1820 . There were the remains of a fer cobs left of the early fishermen before the Revolution.

The Georges balibut and cod fishery is of more recent date. It became a permanent business enterprise in the years of 1835 and ' 36 , although vessels commenced going there for halibut some five years previous, in 1830. In the first years of the business the catch was almost entirely of halibut. In a full fare there would not be more than from six to ten quintals of codfish caught. Halibut were so plerty in these early years of the Georges fishery, and for some years after, that trips were got without anchoring the vessel at all. Severfl ressels went with their chain cable only. These trips of halibut were marketed mostly in Boston. In 1848 this school of halibut culminated. This, also, was the season of the Gloucester Halibut Company. The wonderful catch that Spring greatly overstocked the marliet; so much so, that under the stated price agreed upon, the company could not continue through the month of April, and had to stop fulfilling their.contracts, and wind up. As an evidence of the abundance of these fish this season, we have only to mention that at one time in April nearly half a million pounds of balibut were afloat in this harbor.

About this time codfish were first sold fresh, after being dressed, from the vessel, thus commencing the marketing of all kinds of fish on their arrival in port. Heretofore the fish were landed and salted and put into the shoresman's hands for drying, the allowance to him being one fourteenth part of the net proceeds for his services, to be 
deducted from the gross stock, the balance to be divided equally between the owners and crew.

During the month of September, 1819, as the boat Madison was at anchor on Middle Bank, codfishing, a large school of halibut were struck. One hundred and forty were caught, and the vessel immediately got underweigb for Boston, where the halibut were sold for one dollar each. The boat was owned and commanded by Capt. George Wonson. He had with him, as crew, Moses Parsons and Benjamin Robinson.

In the year 1840 the schooner Nautilus, (heretofore spoken of as making the first trip to Georges for halibut,) Frederick Gerring, master, and the schooner Phœnix, William H. Rowe, master, made a trip to Georges, bringing in full fares, and were absent from port but seventy-two hours. We fail to learn of any quicker time than this, and think it would be hard to beat it. They had good runs both ways, and began catching halibut as soon as their anchors were down.

\section{The Commerce of Gloucester and the Fisheries.}

The commercial interests of Gloucester were at one time quite extensive, and aided greatly in building up and adding to the wealth and prosperity of the place. An antiquarian friend has recently been poring over some old account books, and informs us that he finds, during the time between 1795 and 1810 , the names of eight ships and twenty-five brigs, which were then owned and fitted at this port. The West India trade was a source of profit for many years, especially that of the Surinam branch; but now its glory has departed, and there is not a vessel from this port engaged in it. Occasionally a craft is fitted from Boston, in which a Gloucester merchant is interested; but aside from this, the trade has passed into other hands. All the energies of our people are concentrated in the fisheries, and in this branch we beat the world. From present indications there is much to encourage the pursuit, and old Gloucester has tacitly consented to let other ports have the swing of commerce, while she looks sharp after the interests connected with the hook, line and net. New firms are constantly engaging in the business, and if energy, tact and pluck avail anything, there is no fear for the future prosperity of our city. 


\section{The Winter Fishery of 1846-A Comparison between Then and Now.}

We have succeeded in obtaining a carefully compiled statement of the doings of the winter fishing fleet on Georges, during the season of 1846. There is such a contrast between the business then and now, that we feel assured the details will be of interest to the reader.

The entire fleet which followed winter fishing at that time comprised twenty-nine vessels, as follows : - Schooners Mount Vernon, Clarissa Story, Oregon, Hosea Ballou, Huntress, Columbia, Adeline, Champion, Union, William Wallace, Hannibal, Clarion, Alabama, Concordia, H. A. Holbrook, Canton, Centurion, Constitution, Clinton, Pilot, Richmond, Sarah, Napoleon, Zanoni, William Penn, Emerald, Revenue, Cinderella, and Science. Their average measurement was sisty-two tons; average value $\$ 2,800$, and were considered the staunchest vessels belonging to the port. The greater number of these ressels have either been lost or sold from this distriet. The first ten of the above list left for Georges, January 5th, and averaged five trips each, during the season. Their net stock amounted to $\$ 11,870$, and the arerage net earnings of the vessels were $\$ 151.50$. The largest fares brought in, were the first two trips of the William Wallace, Captain James Pattillo, amounting respectively to $\$ 500$ and $\$ 610$. The arrival of these trips produced quite a sensation, and was the theme of conversation in the stores, on the wharves, and on the street. The William Wallace was the lucky craft, and to her captain and crew was accorded the honor of being "high liners" of the Georgesmen. She stocked $\$ 2,135$ for her season's work.

The next eleven vẹsels of the list did not go so early in the senson, but deferred their departure till Iebruary 6th. Their stock was $\$ 8,844$, and each vessel areraged $\$ 128.36$ net carnings. The remaining eight started March $2 \mathrm{~d}$, and netted $\$ 110$ each. The total stock of the fleet to April 15 th, amounted to $\$ 25,106$, and the arerage share of each man was $\$ 62.16$.

In those days halibut comprised the principal fish caught on Georges, and the amount of codfish caught was small. Now it is reversed, and codlish are the most plentiful. What a contrast - then and now ! Instead of the fleet of trrenty-nine, of trenty-seren years ago, there 
are now two hundred and fifty sail engaged in the business, whose arerage valuation is $\$ 6,000$. The trips brought in during the best part of the season will arerage $\$ 700$, and stocks of from $\$ 1,500$ to $\$ 2,000$ are not unfrequent; while the Grand Bank fishery, comparatively a new branch of the business, often discounts from $\$ 3,000$ to $\$ 4,000$ on a single trip; the result of the energy and pluck of our fishermen.

Previous to 1846 the vessels did not carry ice, but many of them were made into "smacks," so called, which was done by building a water-tight compartment amidships, and boring holes in the bottom to admit the salt water, and thus the halibut were kept alive. The other vessels were obliged to risk the keeping of their fish, and made trips as speedily as possible. The "smacks" did not give much satisfaction, as oftentimes the wells would leak, which made considerable work for the pumps, and such work is not relished by either sailors or fishermen. Then again, when in Boston harbor, the water being so different from that outside, would often have a bad effect on the halibut. In 1848, when the Halibut Company was formed in town, ice was introduced, and "smacks" were no longer necessary.

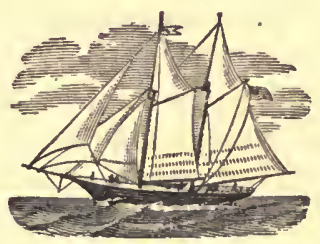




\section{"Uncle Charlie's" Recollections of the Old Pinkey and Jigger Fleets. Also, of the Square Sterners, Half Clipper, and Clipper Model Fishing Vessels.}

Cruising along the wharres one afternoon in June in search of information relative to the crews of some of the lost fishing vessels, we came across Uncle Charlie, the veteran fisherman, who was cosily soated on a barrel smoking his pipe and gazing off in the harbor, watching the vessels coming in and ont. Now Uncle Charlie is a character well worth knowing, one of that class of fishermen of whom there are but few left, who has followed the business for threescore years, commencing when a lad of eight, and in his day has taken au active part in all the branclies of the business, thoroughly understanding the details of each, and, when in his prime, there were but few men in the fleet who could eatch more fish or do a better day's work on board the vessel than he could.

When we first saw the reteran sitting so comfortably on his barrel, the thought of "interviewing" him and thereby obtaining a clapter for our Memorial Book, at once came into mind, and seeing that the old man was in good trim, we took a seat near him, on the capstan of the wharf, and were soon engaged in conversation.

How quickly did the old man's thoughts go backwards orer the past, as we put a few leading questions! How vivid was his memory of the old-time fishing fleet, and how his eyes sparkled and how brightly his face shone with pleasure as he related, one after the other, faets and incidents of the "pinkey" and "jigger" flects, recalling the names of some who then took active part, with hook and line, but who many years ago sailed for the port beyond, learing their boats and all things pertaining thereto! Uncle Charlie will, one day, not very far abead, sail over the same waters, reach the same port, and is there any doubt but that he will meet with those gone on before, and be known and recognized as of old? We believe that he will.

This is a digression. 'We were seated on the capstan of the wharf, the veteran on his barrel, a cool breeze blowing, and perfect harmony abroad that bright summer afternoon. 
"Now, Uncle Charlie, we want you to talk to us about old times, tell us about the old fishing fleet, as we are going to get up a book for the fishermen of to-day, who will want to know all about the past, and how the old fishermen used to manage, and what kind of crafts they sailed in."

"Well, let me see. I'll spin off the yarns, and you can put 'em together to suit yourself. I don't know anything about your printing, never had but precious little book larnin', any way. At the age of eight I began to get my own livin', and what little I do know, I picked up winter evenings."

"That don't matter, Uncle Charlie. Spin off the yarns, and we'll endeavor to put them in shape."

Would that we could report that afternoon's interviewing, verbatim, giving the exact language, the style, the gestures, etc.; but we cannot do that, and must rest content by giving a general summary thereof.

Uncle Charlie's first rememurance was of the pinkey fleet. Sixty years ago, he tells us, the whole of the fishing business of Gloucester was, with the exception of the Grand Bank fishing, carried on by means of these small and light craft. Their trips were seldom extended to more than two or three days or a week, according to the success they might meet with. They were mostly occupied upon the fishing grounds in the vicinity of the Cape, sometimes running down along the coast of Maine, and occasionally dropping their lines upon Georges. These boats were from ten to twenty tons, with standing rooms or berths, for they had no rail or bulwarks above the deck, the only protection being a narrow waist about eight inches in height. They carried foresail and mainsail only, and were good sailers. The "cuddy," a small apartment forward, contained two berths, and a fireplace built of brick, just abaft the foremast. The chimney was made of wood and plastered on the inside to prevent its taking fire. Cooking-stoves were then unknown.

Uncle Charlie recalled among the names of the Pinkey fleet, the following: "Lion," Capt. Simeon Burnham; "Mary," Capt. James Marchant; "Nabby," Capt. Epes Merchant; " Heart of Oak," Capt. William Parkhurst; "America," Capt. Nathaniel Merchant; "Fin Back," Capt. Samuel Norwood; "Sukey," Capt. Benjamin Parsons. There were also some three or four owned by the Wonsons, at Eastern Point, whose names he did not remember. These comprised the fleet from Pearce's wharf round to Rocky Neck. In addition to the above was the Harbor Cove fleet. 
The fitting-out of the fleet for the haddock fishery commenced about the first of $\Lambda$ pril. The first move was to run the boats on the beach, or landing as it was then called, and have thetn calked and graved. The latter process consisted in applying a coat of pitch to the bottom and burning it down with a tar-barrel, which gave a smooth and glossy surface. Printed bottoms in those days were very rare. After this process had been gone through with the sails were bent, and then a supply of stores was taken on board, comprising the following articles: Two quarts of molasses, five pounds of fat pork, four pounds of flour, seven pound's of hard crackers, (baked by Capt. Currier, or "Capt. Kier," as he was fanniliarly called,) half a barrel of water, and a little New England rum, which in those days was considered both victuals and drink. This stock would last about a week. Some of the fishermen of the present day would rather grumble at such a bill of fare, but it answered the purposo very well, and they were perfectly contented with it. Another essential article on board was a box of tiuder and a supply of home-made matches dipped in brimstone. 'The tinder wats ignited by means of flint and steel, and by this they lighted the matches, - not a very agreeable job to perform when it was rough, especially if oue was a little "squeamish," as the smell of brimstone was almost sure to make a person "heave up."

The time occupied in making a haddock trip was from two clays to a week, the fish being mostly taken on Old Man's Pasture, Heart's Ground and Inner Bank, about twelve miles off of Eastern Point. The fish were taken to Clarlestown for a market, and purchased by the hawkers - among whom were Johnny Harriden, Joe Smith, Isaac Rich and others, who took them over to Boston in hand-carts and retailed them at a good profit. The codfish were generally salted. The smallest were cured for the Bilboa market, and the largest were made into dun fish, as they were called, for home consumption. They were kept on the flakes several weeks, and thoroughly dried until they became of a redlish color, and were highly esteemed as an article of food. The haking season commenced in July, and the pollock fishery was prosecuted from September to the middle of November. Each boat carried three men - skipper, forward hand and cook, who went at the halves, as it was called, the crew receiving one-half the gross stock, and the owners the balance.

The full rig costume of "ye ancient fishermen" would be regarded at the present day as something of a curiosity. It consisted generally of the tarpaulin hat and monlicy jacket, or guernsey frock; the 
barvel - a stout apron of leather, and the ponderous fishing boots, of astonishing breadth of beam, made of the thickest of russet cowhide, with tops made to turn up bigh over the knees, and though cumbrous and heavy, constituted an efficient protection against cold and wet. Unele Charlie recalled to mind the familiar forms and weather browned faces of many of these veteran sons of old ocean "whose march was on the mountain wave, whose home was on the deep." There wcre the Marshall Brothers, familiarly known as Tim and Bill; Atkinson and Millett; Abraham Wharf, Isaac Jeffs, Philip Priestly, John Truebody, and many others.

Following the pinkey fleet, came a larger class of boats, of thirty tons and upwards. These boats at first were the same rig as the smaller class, and had no bulwarks or bowsprit. They had stanchions, rail, and a narrow strip above the waist about six inches wide, the rest of the space being left open, as it was then deemed unsafe to have bulwarks, the plan of having seuppers to let out the water not being adopted until several years afterwards. These boats subsequently had their stems sawed off and were rigged with bowsprits, carrying foresail, mainsail and jib, and known as "jiggers." They were considered very large vessels at that time, and competent to make a voyage to any part of the world.

The first of the fleet of this class was the "Presiclent," twenty-eight tons, commanded by Capt. Simeon Burnham, and the "Union," twenty-four tons, Capt. Epes Merchant, which was subsequently taken by the privateer Rolla, but afterwards liberated. Then came the "Constitution," thirty-two tons, Capt. William Parsons, which was the largest jigger of the fleet, - so large that it was feared she could not be worked out and in from the upper harbor cove, consequently she had to be moored off the harbor rock. The "Madison," twenty-seven tons, was commanded by Capt. William Parkhurst. She was a very fast sailer, and during war-time was purchased for a privatecr, bringing in two prizes in one week. There were also several others, and it may be a matter of interest to state that the cost of bpilding these boats was from sixteen to eighteen dollars per ton. Quite a differ-" ence between then and now. These jiggers were furnished with a small fireplace and chimney, built of brick, in the cabin or "cuddy." The chimney came out flush with the deck, and upon that a square wooden box or funnel, which could be removed as occasion required. These little chimneys had a merit peculiarly their own. They werc sure to carry smoke at all times, one way or the other - either upward or downward - and it was to this " habit of smoking," as Unele Char- 
lie affirmed, especially of the Grand Bankers, that they were indebted in thoso days for an occasional tasto of the most delicious smoked halibut. Tho curing of halibut was not then, as now, a branch of the fishing business. Occasionally one would take the hook, and if it proved a particularly fine fish, the best cuts wero taken of and suspended to tho beams in the cabin, and by the end of the royago would become thoronghly cured by the smoke, and being divided among the crew, were taken home to their families, for their own use, and given as very acceptable presents to friends.

Theso littlo vessels from their extreme buoyancy and their offering so little resistance to the power of the ocean waves, would make comparatirely gool weather at times when large ships would be 12 boring, plunging, and straining every plank and timber to its utmost capacity of endurance. They would mount almost upon even keel, upon the erest of the highest seas, and settle into the hollows with the ease and grace of a wild duck, and such a thing as " shipping a sea" was not thought of.

The manner of mooring the boats in those clays was peculiar. $\Lambda \mathrm{s}$ there were but few wharres, the fleet wero kept moored in the harbor. The mooring consisted of a large flat stone, weighing from three to four tons, with a hole in the centre about eight inches in diameter, into which a straight white-oak butt, about serentecn feet long, was inserted, so that at high tide some three or four feet of the stump was visible above the water. Upon the stump ras a "crab," made of a large log eighteen inches long, with a hole in the eentre large enough for the stump to go through; this played up and clown, and was prerented from slipping off by means of a strong "fid." A piece of sixinch cable, about five fathoms long, was attached to the "crab," and on the other end an eye was spliced large enough to slip over the stem of the pinkey. This was kept afloat by means of a small buoy, so that when a boat was running in she would make for her mooring, and a man gaffed the buoy, slipped the collar orer the stem, and the boat was safely moored. A few of these old mooring-stumps are now visible at low water in some of the cores, but most of them have disappeared.

Of the squaro stern fleet he remembered the Accumulator, Delegate, Helen Marr, Forest, and Mount Vernon. They were full, square-bowed ressels, with short, chunky cutwaters, the head and trail boards being paiuted in bright chrome yellow, and occasionally one would secure an extra touch of gold leaf. The bottom was painted green up to the bends, and the npper-works black, with a broad 
white streak on the waist, and some would have a yellow bead on the lower edge of the bends. This was considered rather an expensive luxury, and was rarely indulged in, as the fishermen of those days did not pay so much attention to ornamenting their vessels as do those of modern times.

Next to this class of ressels came the half-elipper models, which were considered something extra, and the old fishermen wondered how people could be so foolish as to risk their lives in such vessels. There was the Ilosea Ballou, Daniel D. Smith, Henry Ilolbrook, and others which represented this class. They were very pretty looking crafts for those times, but at the present look almost as old style as those first mentioned.

The first regular clipper craft owned here was the Romp. She was built in Essex, about the year 1850, as near as Uncle Charlie could remember, and purchased by Capt. Samuel Giles. On her arrival in this port she formed the general topic of conversation among the fishermen, some declaring that a crew could not be obtained to go in such a sea-coffin, and the man who built her must be insane. She would never come back to port if she went out, said some of the old veterans, as they went on board and gave her a thorough cxamination. Notwithstanding all this croaking, the vessel was fitted and sailed for the Georges, proving not only an excellent sea-boat, but one of the fastest ressels in the flect. The Romp proving such a superior craft, others were built on her model, which was improved upon, and we now have a fleet of fishing vessels which are the very pictures of neatness and beauty, so closely resembling yachts that some of the latest build are often taken for such, when they are skimming so gracefully over the water.

Very pleasantly passed that summer afternoon, and we have cndeavored to tell what Uncle Charlie related; but it lacks that peculiar spirit and zest which an old salt alone can impart, and which rendered the interview so very interesting to us. 


\section{Account of the First Trips to Georges after Halibut.}

It is claimed by $n$ large majority of those interested in the fisheries, that the schooner Nautilus was the first vessel which ever ventured to Georges on a halibut trip. There are others who assert that the schooner Romeo is entitled to the claim of being the pioneer schooner in this branch of the fisheries. We have made the most careful inquiries, and from one of the crerr of the Nautilus we obtain the date of her sailing, and sercral interesting particulars of the trip. We could not obtain nny date of the sailing of the Romeo, although we interviewed one of her crew. He felt confident that there was not many days' difference in their time of sailing, and was rather inclined to the opinion that the Nautilus was the first. Our informant is positive that he is correct in his dates, and as he is a man of undoubted reracity, and in the absence of any contradictory statements, we publish his narrative. The vessel was commanded by Capt. John Fletcher Wonson, recently deceased; one of the most able and careful skippers among those of the olden time.

In 1828, while coming home in the Nautilus, from Wilmington, $\mathrm{N}$. C., he noticed on the chart used on board the ressel, a picture of a halibut, under which was printed the words, "Good halibut grounds here." This he remembered, and, tro years after, concluded to give halibut catching a trial. On the fifth of March, 1830, the vessel started out of the liarbor on her trip for halibut. Among her crew was the following persons, all of whom but the last named are now living : John T. Wouson, Nathau F. Wonsou, Samuel G. Wonson, Daniel Douglass and Benjamin Marble. The result of this trip was twenty halibut, which were landed, but met with a dull sale. The sehooner Romeo, Capt. Henry Pew, sailed soon after, and brought in a trip of upwards of three thousand pounds, which were sold for three cents per pound. Other vessels soon followed, but the business did not amount to much until it bad been prosecuted five or six years, when it began to assume considerable importance, and became established as a regular branch of the fisheries.

This first trip of the Nautilus came very near being the last to one 
of her crew, Mr. Marble, and gave a little foretaste of the dangers accompanying the rocation. The vessel was lying to, the crew having succeeded in finding some halibut, when Mr. MIarble launched the dory, and throwing over his anchor, commenced fishing by himself. It was quite moderate, and the resscl, drifting with the current, was scon some distance off. This was thought nothing of in the excitement attending fishing, until one of the crew remarked that Marble was about out of sight, and he thought it queer that he didn't row for the ressel, especially as night was coming on and there were indications of a storm. All hands then began to talk it over, and thought that something must hare happened to him. A man was sent aloft to keep the dory in sight, and a little breeze springing up, the ressel was got underway and they succeeded in reaching him, just before the darkness and the storm came on. It secms that in the hurry of launching the dory he forgot the oars, and this accounted for his not attempting to regain the vessel. There lay the oars on the vessel's deck, and not one on board had observed them. If they had, the mystery of Marble's not attempting to regain the ressel would soon have been solved. 'Soon after he had been picked up, the storm camc on in all its fury, a regular Georges blow, with all the accompaniments, which would have proved certain death to any one exposed to its fury in a dory.

There was quite a difference in the style of living on board the vessels in those days in comparison with that of to-day. Fish formed seventy-five per cent. of the food. Twenty-eight pounds of flour was the allowance for a trip, and twenty-five pounds of beef and pork, with plenty of hard bread. A favorite dish was the "Dundee Pudding," made of hard bread, pounded up, sweetened with molasses, with some flour stirred in to give it a little of the adhesive quality. A very palatable dish it was when properly concocted. Hard bread, fried in pork fat, was another standing dish on the bill of fare. What would the fishermen of to-day say to this style of living, and how would they like to return to the days of 1830 , when the first Georgesman passed out by Eastern Point, and returned with her fare of twentv halibut? 


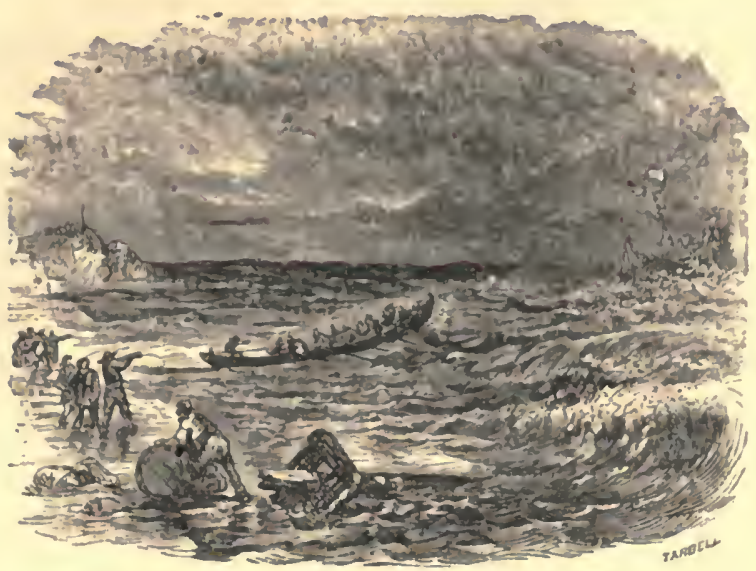

\section{Incidents of the Gale of September 8th, 1869.}

On the evening of September 8th, a most terrific gale sprang up, which, for a short time, was the most severe, on the Eastern coast, within the memory of some of our oldest fishermen. The weather in the early part of the afternoon was quite warm and pleasant, and no one ever dreamed of sich a sudden change. At about half-past threo o'clock the wind began to breeze up from the south-east, accompanied with rain, and, at half-past five, it had increased to a perfect hurricane, which for two hours raged fearfully. Vessels dragged their anchors and were diven ashore, trees and chimnies were blown down, awnings ripped from their fastenings, windows blown in, and general destruction prevailed. Fortunately there were but few vessels at anchor in the harbor at the time. In addition to the pilot-boat Youxg Raves, mentioned among the lost vessels, two Cape Cod fishing ressels, the Wisslow, of Plymouth, and the Ricmard P. Higgrs, of Wellfleet, also an Eastern coaster, came ashore on the beach, and were got off next day, having received but little damage. The lifeboat was launched and did much service in saving the crews of the wrecked vessels. Several unsuccessful attempts were made to reach them, and it was finally deemed an utter impossibility, such was the fearful power of the sea. But just at this moment, Mr. Sruyaxus 
HARDY volunteered to take charge of her, and called for a crew. EDward S. Jones, William Yates, William J. Fisher, Peter Eagan, Peter H. Eaton and William Consers, promptly responded. They succeeded in reaching the ressels and saving several of the men, which deed justly entitles them to honorable mention.

During the delay atteridant upon the successful launching of the life-boat, it was evident by those on the beach that the men on board one of the vessels might be saved if a rope was got on board. But who would risk his life to carry the line? There was danger in performing such a feat, especially if the person was not an expert swimmer and possessed of strong powers of endurance. There was a pause for a moment among the men on the beach, when a voice rang out clearly, speaking the checring words, "I will try it!" It was Mr. Moses MerLetr who uttered these inspiring words, and his appearance betokened that he was in earnest and ready to risk his life to aid those on board the wrecked vessel. He was soon prepared for the perilous task, and plunged into the seething waters. The feat was attended with much danger; but the noble fellow swam vigorously and persevered until he reached the vessel, and succeeded in rescuing three of the crew, who saved themselves by dropping into the life-boat from the rope. Such deeds are truly beroic - when men risk their lives in order to succor those in distress.

Yacht Editn, owned by Mr. George O. Hovey, was caught out in this gale with a party on board, among whom were MIr. Hovey, Rev. Dr. S. K. Lothrop, and the Messrs. Appleton and Dale. Capt. George Sawyer, the pilot, was in command, and brought her to under Ten Pound Island, but subsequently concluded it best to run for her moorings at Fresh Water Cove, which were safely reached after much difficulty. The party liad two alternatives before them, - to remain on board the yacht and run the risk of her going ashore, or to endeavor to effect a landing in the boat. They concluded to accept the latter, and after considerable exertion wcre safcly landed. Shortly after, the yacht dragged heir anchors and went ashore on Rattlesnake Head, and such was the force of the waves, that it was impossible to make any attempt to rescue Capt. Sawyer and his crew from their perilous situation until about nine o'clock in the erening, when Messrs. IsAaC Morse, Daniel S. Parsons, Josepu W. B. IIlliter and Ayrbose WISE succeeded in reaching the wreck, and brought the men on shore. They were very nearly exhausted, and could not have survived but a short time longer. These men performed an heroic act, attended with great danger; but they conquered every obstacle, displaying 
great bravery and coolness. The Mass. Ilumane Society remembered them with suitable testimonials of their appreciation of the gallant deed they had accomplished. The yachit was subsequently got off and repaired.

During the gale ten of our fishing fleet, were driven ashore along the const, three of which proved total wrecks, and are enumerated in the list of that year's losses. Most of the others required large outlays for repairs.

\section{Sea Fish and Fisheries.}

If the sea is prodigal of life to a degree that baftles our powers of conception and calculation, it is no less a scene of boundless destruction. The life of all fishes is one of perpetual warfare, and the only law that pervales the great world of waters is that of the strongest, the swiltest and the most voracious. The carnage of the sea immeasurably exceeds even that which is permitted to perples our reason on the eartl. We know, however, that without it the population of the ocean would soon become so immense that, vast as it is, it would not su@ee for its multitudinous iuhabitants. Ferw fisles probably die a natural death, and some seem to lave been ereated solely to devour others. There is probably none which rloes not feed on some other suecies or its own. Many of the monsters that roan the watery plains are provided with maws capable of engulfing thousands of their kind in a day. A hogshead of herrings has been taken out of the belly of a whale. A shark probably destroys tens of thousands in a year. Fifteen full sized herrings have been found in the stomach of a cod. If we allow a colfish only two herrings per day for only seven months in the year, we have 420 as his allowance during that period, and fifty codfish equal one fisherman in destructive power. But the quantity of cod and of ling, which are as destructive as cod, taken in 1861, and registered by the Scotch fishery boarl was, say the commissioners, over $81,000 \mathrm{cwts}$. On an arerage thirty codfish make one hunclred weight of dried fish, and 2,400 ,000 will equal 48,000 fishermen. In other worls, the cod and ling caught on the Scotch coast in 1861, if they liad been left in the water would have devoured as many herrings as were caught by all the fishermen of Scotland, and 6,000 more in the same year. Compared with the enornous consumption of fish by birds and by each other, the draughts made upon the population of the sea by win, with all his ingenious fishing devices seem to lwindle into absolute insiguificance. 


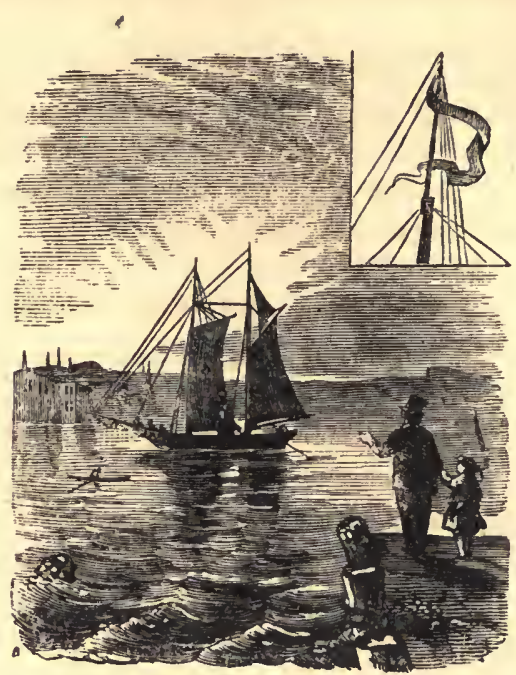

\section{Big Trips in the Bank, Georges, Mackerel and Haddock Fisheries,}

As a matter of interest and for general reference, we publish below some of the largest stocks made in the Grand Bank, Georges, Mackerel and Haddock fisheries, during the past ten years. These stocks, however, are exceptional, and not the rule. Fifteen hundred to two thousand dollars is considered a very good amount for a fresh halibut Bank trip, although stocks from two to three thousand dollars are not uncommon. Stocks from three to four thousand dollars are rare, and in but very few instances bas a vessel exceeded $\$ 4,000$. One vessel, only, has stocked rising $\$ 5,000$.

A Grand Banker averages about nine trips a year, and the trips vary from $\$ 8,000$ to $\$ 17,000 ; \$ 12,000$ being about the average. It is not always the vessel which gets the largest number of halibut that makes the biggest stock. It all depends upon hitting the market right. The highest stocks realized have been on fares of from forty to fifty thousand pounds, while it is frequently the case that fares of from seventy-five to one bundred thousand, arriving when the market is a little glutted, realize less than $\$ 2,000$ stock.

The Grand Bank halibut fishery is of comparatively recent date. The first ressel from this port that went there for halibut, was the Hattie M. Lyons, Capt. 'George W. Miner, owned by Messrs. D. C. \& H. Babson. She left here in May, 1865, and made her trip in four 
weeks, bringing in 75,000 pounds of balibut and 6,000 plounds of codfish; her net stock amounting to $\$ 3,468$, which was the largest stock up to that time ever made in a halibut trip. The following jear several other vessels engaged in the business, and it soon became a prominent branch of the fisheries.

\section{BIG TRIPS IN THE BAXIS FISHERY.}

The largest stock made in a season's fishing to the Banks was that of schooner Racer, Capt. Walter Falt, in 1866, amounting to $\$ 22,000$. Capt. Wm. Thompson, now master of schooner Alfred Walen, was ono of the Racer's crew that year, and was " high line," realizing $\$ 1,300$ as his share of the stock, - a pretty good year's work.

Schooner Mary Carlisle, Capt. William Thompson, comes next on the list, having made nine trips to the Banlss in 1871, and landed 350,188 ponnds of halibut, and 58,759 pounds of codlish, her net stock amounting to $\$ 17,275.53$. She commeneed the season Dec. 27 th, 1870 , and arrived from her last trip Nov. 21st, ' 71 , having been employed about eleven months. Her crew numbered ten men, who shared $\$ 858.62$ each. The Mary Carlisle has been an unusually lucky resscl, Capt. Thompson baving stocked in $1869, \$ 17,549$; in 1870 , $\$ 12,047$; in $1871, \$ 17,275.53$; a total of $\$ 46,871$ in three rears. Orned by the master, and Leighton \& Co.

Schooner Oliver Elitridge, Capt. Michacl MeDonald, in 1872, stocked $\$ 16,097.40$ in eight trips to the Grand Banks. Owned by George Steele.

Schooner Frank A. Williams, Capt. Dennis C. Murphey, the same year stocked $\$ 15,855.43$. Owned by William C. Wonson and the master.

The highest stock ever made in a single fresh balibut Bank trip) was that of schooner N. II. Phillips, Capt. William McDonald, in 1871. She weighed off 47,650 pounds of halibut, which brought $\$ 5,105$, and 9,390 pounds codfish, which brought $\$ 256$, making the total stock $\$ 5,361$. Crew shared $\$ 213.42 \mathrm{cach}$. Time occupich in making the trip, five weeks. On her former trip she stocked $\$ 3,781$, the crew sharing $\$ 150$ each, making a total of $\$ 9,142$ for both trips, made mithin nine wecks. Orrned by Walen \& Allen.

Schooner Mary Carlisle, Capt. William Thompson, in 1871, brought in 58,553 pounds halibut, and 6,900 pounds codfish, her net stock aruounting to $\$ 4,738.75$. Crew shared $\$ 236.25$ each. Time occupied in making the trip, thirty-four days.

Schooner Sarah P. Aycr. Capt. J. Marsh Thurlow, in 1869, in a 
thirty-days' trip to the Grand Banks, stocked $\$ 4,251$, the ererr sharing $\$ 670$ each. Capt. Thurlow was very lucky that year, having stocked in five trips upwards of $\$ 12,000$. Owned by Dennis \& Ayer.

Schooner Aphrodite, Capt. Randall MIcDonald, in 1867, stocked $\$ 4,126.72$, having been absent only twenty days. Crew shared $\$ 171.51$ each. Owned by Dennis \& Ayer.

Schooner William T. Merchant, Capt. Nelson McKenney, in 1868, stocked $\$ 4,200$ on a fare of 48,310 pounds of halibut, the trip occupying twenty-six days. Owned by Shute \& Merchant.

Schooner C. B. Manning, Capt. Charles II. Nute, in 1869, stocked $\$ 4,033$ on a fare of 40,000 pounds of halibut, and 14,000 pounds codfish. The trip was made in four weeks, the crew sharing \$161.06 ench. Owned by Peter Sinclair.

Schooner Elisha Crowell, Capt. Thompson, in 1870, brought in 60,260 pounds halibut, having been absent less than four weeks, and stocked $\$ 4,000$. Crew shared \$162.04 each. Owned by Walen \& Allen.

Schooner Peter D. Smith, Capt. Burnham, in 1871, stocked \$3,928.84 on a fare of 45.638 pounds balibut, the crew sluaring $\$ 160.55$ each. Cook, \$191.03. Time absent, five weeks. Owned by Smith \& Oakes.

Schooner Mary G. Dennis, Capt. Randall MeDonald, in 1868, brought in 75,395 pounds halibut, and 9,950 pounds codfisb, and stocked $\$ 3,604.85$. Crew shared $\$ 143.85$ each. Time absent, four weeks. This same schooner in 1872 , weighed off 105,000 pounds halibut, the largest fare of fresh halibut ever landed at this port. Prices ruled low at the time, and she realized but $\$ 2,000$ stock. Orned by Dennis \& Ayer.

The second largest fare of fresi halibut was brought in by schooner Montana, Capt. Moses Welch, in 1868, who landed 95,773 pounds halibut, and 2,250 pounds codfish, her stock amounting to $\$ 3,265$. Owned by Rowe \& Jordan.

\section{LARGEST SALT FARES.}

The largest fare of fletched halibut ever landed at this port was that of schooner Caleb Eaton, Capt. John MICQuinn, in the Greenland fishery, in 1870 . She brought in 177,300 pounds of lletched halibut and 183 barrels of fins, which were purchased by Dodd, Tarr \& Co., for nine and ten cents per pound, the fare amounting to $\$ 17,811$. In addition to the above were several barrels of salmon, which were sold at a good price, and her entire stock amounted to about $\$ 20,000$. Time occupied in making the trip, about four montbs. The Caleb Eaton is owned by Mressrs. Brown \& Seavy, of Boston. 
The largest salt fare from the Grand Bauks was brought in by schooner Reunion, Capt. Belcher Torrey, in 1868. She weighed off $153,0.44$ pounds halibut, and 23,875 pounds codlish, her net stock amounting to $\$ 8,354$. The crew shared $\$ 286.63$ cach. Time absent, twelve weeks. Chartered by D. C. \& II. Babson.

Schooner Carric P. MIcrton, Cant. Charles $\Lambda$. Keene, in the season of 1873 , weighed off 122,000 pounris collish, and 28,050 pounds halibut, her net stock amounting to $\$ 7,888$. Crew shared $\$ 326.16$ each. Time absent, fro montlis. Orrned by Walen \& Allen.

Schooner Innight Templar, Capt. Michacl MIcDonald, the present year, weighed off 85,000 pounds halibut, and 73,938 pounds coilish, ber net stock amonnting to $\$ 7,681.25$. Considering the time occupied in making the trip, which was but two and a half months, this is the best Bank stock made. Owned by George Steele.

Schooner Ben: Perley Poore, Capt. Charles II. Nute, in 1872, bronght in 180,695 pounds codfish, and 10,597 pounds halibut, her stock amounting to $\$ 6,345.69$. Crew sliared $\$ 257.29$ each. Time absent, fourteen weeks. Owued by Peter Sinclair.

\section{LARGEST GEORGES TRIPS.}

In 1865, schooner Everelt Stecle, Capt. Cash, brought in 75,769 pounds coclfish, ancl stocked $\$ 2,824.55$, the largest stock erer male in a single trip to Georges. The cook realized \$181.0t as his share. A pretty gool fortnight's work. A rerage share of crew \$1:0. The following year, under command of Capt. Jas. Lunticrkin, sle brourht in 99,338 pounls fisl, and stockel $\$ 2,735.95$; and in 1S69, unie: commancl of Capt. Jos. Goslin, weighed off 102,075 pound's (the largest amount ever landed in one Georges trip), snd stocked $\$ 2,760.69$, the cook realizing $\$ 160$ as his sbare; areraro share, $\$ 125$. The sereral trips occupied about a fortnight cach. Omned by George Sicele.

Scbooner Madame Roland, Capt. Lunderkin, in 1865, stocked $\$ 2,217.76$ on her Erst trip to Georges, and $\$ 2,833.29$ on ber second, a total of $\$ 5,050,75$ in two trips. Ornel by George Sicele.

The same year, schooner Abby MI. IIcath, Capt. Lee, stocked $\$ 2,625$ in a Georges trip, and schooner Witcheraft, \$2,j8j. Georro II. Wixon, the stewarl of the latter, receiving \$243.32 as his shure of the trip; the largest amount erer realized by one man in at single trip. Orined by the master and others.

Schooner Mooning Star, Cai,t. IIiltz, in 1SGG, stocked 82,400 on a Georges trip, and schooner William J. Roymond, Capt. Cietchil, in 1873, stocked \$2,347.12. Omed by Dennis \& $A$ rer. 
Schooner William J. Dale, Capt. David A. Osier, in 1868, brought in 99,740 pounds codfish, and 2,512 pounds halibut. Her net stock amounting to $\$ 2,073$, fish being low in price at that time. Owned by Dodd, Tarr \& Co.

The largest scason's stock in the Georges fishery was made by schooner Laughing Water, Capt. Jos. Goslin, in 1865, her net stock in eleven trips amounting to $\$ 14,843.84$. She also made one trip to the Bay the same season, her net stock for the year amounting to $\$ 17,954.30$. The high line made $\$ 1,105.37$, and the cook, $\$ 1,402.93$. Owned by John Pew \& Son.

\section{IARGEST MACKEREL STOCKS.}

The largest stock made in the Bay of St. Lawrence mackerel fishery, was that of schooner Col. Ellsworth, Capt. George Robinson, in 1865. She was absent about five months, her net stock amounting to $\$ 13,728$. The high liner's share was $\$ 558$; cook's, $\$ 582$. Louis Wagner, the murderer, was one of the Ellsworth's crew that year. His share amounted to $\$ 307$. Owned by Rowe \& Jordan.

Schooner Gen. Grant, Capt. Coas, in 1864, stocked, in two trips to the Bay of St. Lawrence, $\$ 11,254.94$ clear of all expenses. The high line made $\$ 502.24$; cook's share, \$638.17.

Schooner Nor'wester, Capt. Daniel Hillier, the same year, stocked $\$ 9,721.74$, net, in one Bay trip; the high liner making $\$ 308.60$, and the cook, \$486.61. Both vessels owned by John Pew \& Son.

Schooner General Sherman, Capt. George W. Miner, in 1864, in a three months' trip to the Bay, packed 612 barrels of mackerel, her net stock amounting to $\$ 9,696$. High liner's share, $\$ 575.06$. Owned by D. C. \& H. Babson.

Sehooner Kit Carson, Capt. Horace Merry, in 1865, brought in 591 barrels of mackerel, having been absent about ten weeks. Her net stock amounted to $\$ 6,542$. High liner's share, $\$ 260$. Owned by Rowe \& Jordan.

Schooner James G. Tarr, Capt. Robert Reeves, in 1866, stocked $\$ 5,824$ in a nine weeks' trip to the Bay. Cook's share, $\$ 331.76$. Owned by Dodd, Tarr \& Co.

Schooner Seddie C. Pyle, Capt. Richard Warren, in 1871, packed 1,070 barrels mackerel caught off this shore, in addition to 18,000 southern mackerel sold fresh in New York, in the spring. Her net stock for the year was $\$ 10,561.66$. High liner's share, \$491.38; cook's share, \$708.52. Orned by George Friend \& Co.

Schooner Eureka, Capt. Rowe, in 1868, in six months mackereling 
off this shore, packed 935 barrels, her stock amounting to $\$ 10,748.33$. High liner's share, $\$ 440.82$; cook's share, $\$ 473.70$. Owned by Smith \& Gott, and the master.

\section{I,ARGEST HADDOCK STOCKS.}

The largest stock made in one llay's fishing in the shore winter fishery, was that of schooner Eastern Queen, Capt. William Corliss, who carried into Boston, March 3d, 1873, 25,000 pounds of haddock, and stocked $\$ 1,100$. The Queen also made the largest stock of the season, baving realized in five months' fishing $\$ 10,250$ clear of all expenses. Crew shared $\$ 560$ each. Owned by the master, and John Pew \& Son.

Schooner Jennie B. Thomas, Capt Henry B. Thomas, is second highest of the fleet, having stocked in the season of 1872-3, $\$ 8,000$ in fire and a-half months' fishing. Crew shared $\$ 377$ each. Owned by the master, and Joseph Friend.

Schooner Angie S. Friend, Capt. McLain, in 1870-71, stocked $\$ 7,700$ in five months' fishing. Owned by the master and Joseph Friend.

Schooner Maud Muller, Capt. Nathaniel Smith, in 1871-2, stocked $\$ 6,600$ in four months' fishing. Owned by Smith \& Gott.

Schooner Mary Odell, Capt. MeLain, in November, 1872, stocked $\$ 1,260$ on a haddock trip; the result of three day's' fishing.

\section{How the "Pinkey" Charles Weathered It.}

In the month of October, 1810, a trenuendous gale and snow-storm was experienced along the Atlantic coast. It was remembered for years afterwards as the "October gale." At this time the fishermen who had been out were fortunate enough to make the harbor in good time, with the exception of one, the boat Charles, of about ten tons, manned by John Atkinson and Nathanicl Millet, which was missing, and given over by many as inevitably lost. A week or more afterward one day, when " the south wind blew softly," "pinkey" made her appearance, and ran into the harbor all right. 'The terrible northeaster was down upon them with its blinding snow; they could not make Cape Ann, so they up helm and "let 'er rip" across the Bay, and after a pretty severe thrashing, made a harbor at Chatham. 


\section{Loss of Two Rockport Schooners.}

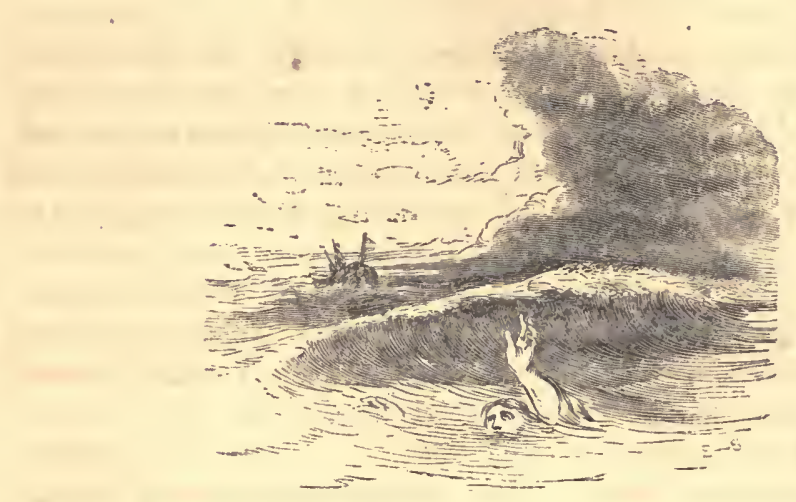

Thrilling Narrative of Mr. Charles Jordan, Sole Survivor of the Crew of the Schooner Helen Eliza-His Perilous Position and Wonderful Escape.

The saddest disasters of the gale of September 8th, 1869, were the loss of schooners Helen Eliza and Yankee Girl, of Rockport, with all on board-twenty-three men, with one execption, Mrr. Charles Jordan, whose narrorw escape we publish in this connection.

Schooner Helen Eliza went ashore at the south end of Peak's Island, Portland Harbor, and went to pieces in a short time. Had a crew of twelve men, as follows: Edward J. Millett, master; Emerson Colby, David B. Harris, Frederic T. Lane, George Wood, Albert 'Tarr, Charles II. Clark, Benjamin Lurvey, Joel Fairbanks, James Bray, George W. Clark. Owned by Capt. Millett, and others, of Tockport. Frederic T. Lane belonged in Gloucester; the remainder in Rockport.

Schooner Yankee Girl was probably sunk in this gale, as she was never heard of afterward. IIad a crew of eleven men, as follows : Clifton Atwood, master; IIorace Atwood (son of master), Freeman and Henry $\Lambda$ bbott (brothers), Alfred Giles, Thomas Williams, David H. Elwcll, all of Roekport; Janes Cam and James Kellogg, of Rockland, Me; Isaac Forrester, of East Boston, and one castern man, name unknown. Owned by Capt: Atrood, William H. Bradley, Jr., and others. 
The fact that out of a crew of twelve men belonging to the sehooner Helen Fliza, of Rockpert, but one man was saved, awakened a fecling of intense interest in this vicinity to learn the full particulars. In an interview with Mr. Jordan, the survivor, we obtained the following thrilling incilents:-

During the latter part of the forenoon of the 8th inst., the weather looked threatening, and Capt. Millett concluded to run into Portland harbor. The first laul mado was Ram Island, about a mile outside of White Heal. During the latter part of the afternoon a thick fog set in, which was followed by a perfect deluge of rain, and the wind increased until it blew a regular hurricane. Both anchors were let go, but the eables partel, and the vessel was put unier short sail. The gale increased fearfully, and the jib was blown clean out of the bolt-ropes. Saw I'ortiand Light, which they undertook to run for, but were too far to the castward to strike the channel. There was no earthly help for them now; with both anchors gone, the wind blowing a hurricaue, and a tremendous sea running, there was but little doubt that the ressel would go ashore at Peak's Island, and, in that erent, the chances of being saved, in such a dangerous locality, were slim indeed. The prospect was a gloomy one, but the erew were unclaunted, and resolved to do their best. Capt. Millett stood at his post of cluty at the helm, to the very last moinent, and in all probability received his death-bluw from the main boom.

After runuing some twenty minutes, the thumping of the vessel's bottom gave evidence that the critical time was near at hand. She did not stop in her course, but kept moving. Jordan went into the forecastle and stripped himself of ererything but his shirt and pants for the coming trial. IIe had hardly done so when the ressel struck heavily, smashing in the bow, instantly lilling five persons who were with lim. IIe inmediately ran into the hold, when a tremendons sea knocked off the deck and he was swept into the raging waters. With a coolness and presence of mind hardly creditable, he seemed, as if by intuition, to at onee realize his josition, and, being an expert swimmer, made for the wreck, which he reached, and elinging to it regained his breath and got rested. Secing an empty barrel 1loating near, he let go his hold of the wreck, and was fortunate enough to secure it. Placing his breast upon the heat, he forced the empty portion under water. 'This served as a great support, and with it he attempted to effect a landing.

'The waves ran fearfully high, and as he was borne along he passed - Geo. W. Clark and Benjanin Lurvey, two of his shipmates, who were 
clinging to a plank. If ever in his life he desired company, it was at this critical time; but prudence whispered that he must not make himself known, for if he did the chances of escape of all three would be rendered far more hazardous. He heard them each speak of their fearful position, and doubting whether they should be able to hold on; and the last words he heard them utter was a promise that if either was saved, they would tell the folks at home the full particulars. It now required his utmost efforts to keep the barrel in position, as the undertow was very powerful; but he managed to do so, and soon saw a ledge of rocks. To effect a landing amid the surf as it beat against its sides, without being injured, was a dangerous task; the waves at one time heaving him toward the ledge, then retreating, would engulf him in their treacherous grasp, threatening every moment to bury him beneath the water. But by the help of his barrel he succeeded, and inserting his fingers in the crevices of the rocks, commenced the toilsome passage up their jagged sides, reaching the top completely exhausted. While resting, he heard the roice of Clark, who was hailing some one. He answered the call, telling him where he was, and enjoining upon him to hold on and try to get upon the ledge. He did not hear him again, and probably the two men were instantly swallowed up in the undertow. He soon found that the ledge did not form a part of the island, but was covered at high water, and, as the tide was coming in, he knew that he was not yet out of danger. After a little time he again plunged into the seething waters; another terrible conflict with the surf followed, in which it seemed impossible for him to make any headway, as his strength was fast failing. Words are inadequate to describe such a situation; moments seemed like hours, and the sullen roar of the waters as they beat upon the rocks was an awful accompaniment. He neared the shore, the dim outline of which he saw, and making one desperate effort, was fortunate in effecting a landing and in getting himself out of reach of the breakers. It was now about nine o'clock in the evening, and the exertions of the past two hours began to tell upon him fearfully, and he could scarcely lift one foot before the other; but he persevered, and emerged into a pathway which led him to a house. It proved to be the residence of Mr. Smith Hadlock. The inmates were at once aroused, and were unremitting in their attentions, furnishing him with a suit of clothing, and doing everything in their power for his comfort.

As soon as he had partaken of refreshments and got rested, he accompanied a party of men belonging on the island, in search for the 
bodies of his shipmates. Mr. Jones, landlord of the hotel on the island, wæs unremitting in his attentions, and secured for him a free passage home. The inhabitants of the island, mostly poor fishermen, made him up a purse of $\$ 18$, and, while in the depot at Portland, $\$ 11$ was raiset in his behalf. The Mayor of the city sought him out, and was also very kind.

This was the third time that Mr. Jordan had been the sole survivor of disaster. Out of a company of eighty, confined in Libby prison during the war, he was the only one who lived to return home; and out of a ship's crew of thirty men, wrecked on Cape Cod, he was the only one saved.

It may be well to state in this connection that, after these remarkable escapes, his death was finally caused by accident. While engaged as a draw-tender on the Boston \& Maine Railroad, he fell from the bridge (during the early part of April, 1873), a distance of fifteen fect, to the platform below, and was so seriously injured that death ensued on Monday, April 21st.

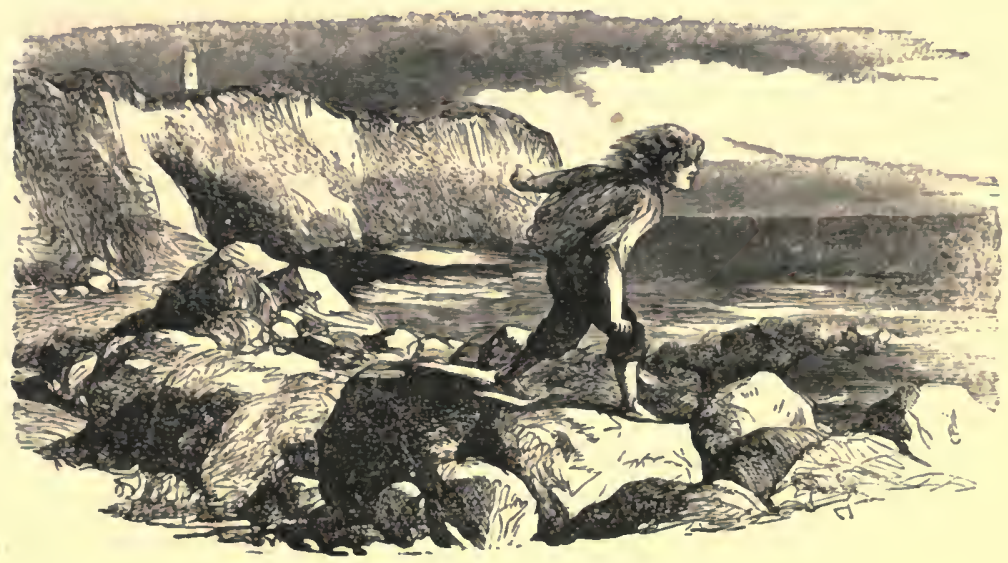




\section{Fishermen's Superstitions - Remarkable Verification of Dreams-Presentiments.}

Fishermen, like, seamen, are quite apt to be a little superstitious, as the very nature of a seafaring life engenders this, and nearly every man who follows the arocation has some pet ideas of this nature, which he cherishes with a sort of sacredness, which possesses to him a sense of reality, and becomes as it were a part of his life. Some are so superstitious, in regard to sailing on Friday, that it would be next to an impossibility to get them to leave port on that day; others have a favorite notion of pitching coppers and nickel coins on Half-Way Rock, whenever the ressel sails near enough to it, for this purpose, and entertain an idea that this will bring them good luck on the trip. Then again there is an idea quite prevalent that, if a single bird should alight on board of a vessel, as they sometimes will, when blown far away from land, no good luck will come from the trip. So earnest are some in this respect that they have actually put back and changed the voyage. It would indeed be very singular if there were not instances where the change of programme has not resulted satisfactorily, and these instances have strengthened the belief in the omen. Some believe in dreams, and are quite tenacious on the subject, and are never so happy as when they have a good dream of their own to relate, or some marvellous tale of the verification of dreams which they have read or heard tell of. Two instances of the remarkable veriffeation of dreams on board vessels of the fleet have come under our notice, as follows :-

\section{THE SINKING OF SCHOONER SACHEM.}

The springing aleak and loss of schooner Sachem, of this port, occasioned by her sinking on Georges, September 8th, 1871, was attended by a singular circumstance, which is fully substantiated by the master of the ressel, Capt. J. Weuzell, from whose log-book we gleaned the particulars :

The vessel left Brown's Bank on the 7th of September, at nine o'clock P.MI.; for Georges, with a fresh N. W. breeze. At mirnight, the steward, Jobn Nelson, arose from his berth, and going aft, where the skipper was, remarked, in an agitated voice, his whole appearance indicating great fear: - 
"Slipper, we are to have a severe gale of wind, or something elso of a dangerous nature is going to orertake the ressel, and we had better mako land if we can, or at least keep clear of Georges, so as not to have it so rough when the danger eomes."

Capt. W. asked liim what made him think so, as everytling was clear at tho time, and there were no apprehensions of trouble or danger.

Nelson replied, "I have been dreaming, and twice before I have had the same kind of dreans when at sea, and both times liare had narrow cliances of being saret. 'The first time we were run into, the day following the dream, and left in a sinling condition. With great efforts in bailing and pumping, we reached the coast of Norway. The other time we experienced a terrible gale, had our sails blown away, and the vessel half full of water; run before it under bare polcs, until we met the northeast trade wiuds, when we patched her up and made out to get into IIavana."

He then told the purport of the dreams, which were of females dressed in white, either standing in the rain, or near a waterfall, or attempting to cross a brook. The figures in each dream were the same, but the surroundings somewhat different.

The steward is a reliable man, and was so much in carnest that the captain, although secing no signs of a gale of wind, and not inclined to be superstitious, concluded it best to be on his guard, and charged the man forward to keep a strict watch.

The wind was now increasing, with a heavy sea rising, and at half past one A. M., the ressel was about five miles from Georges Banks. She was hove to under a close-reefed foresail, and they were furling the balance reef, when a white light was observed to lecward, supposed to be on board a fisherman lying at anchor. Suddenly one of the crew sang out from the forecastle, "The vessel is filling with water!" Telling him not to alarm the men, the captain went down and found six inches of water on top the floor. The pumps were imme. diately manned, and bailing with buckets commenced, after which the captain went sounding arouncl in the hold to find the leak, but the vessel was rolling so hard and the water made so much noise among the barrels and in the ice house, that it was impossible to hear anything else. It was thought the leak was under the port bow, and the vessel was wore round and hove to on the other tack, in hopes to bring the leak out of water. The stewnrd was toll to get some provisions and see that the boat was ready to launch at a moment's notice. It was now blowing a strong brecze from the northward, with 
a heavy sea. They spoke schooner Pescador, and 'told them their condition. With all their pumping and bailing, they could not gain on the leak, and the crew were determined not to remain on board another night. The tideswept them down to leeward of the Pescador, and efforts were made to speak her again, but they could not reach her. Their movements were seen on board the Pescador, and upon asking them to send their boat to take them off, they did so at once. When they left the Sachem the water was eighteen inches above the forecastle floor. At 2 P. M., she rolled over on her side, raised herself once, then plunged under, head foremost, the master and erew feeling thankful to God that they had escaped and were safely on board the good schooner Pescador.

\section{$\triangle$ LITTLE CHILd FOUND FLOATING IN A BOX.}

From Capt. Samuel Elwell, master of the schooner Belvidere, we learned the particulars of one of the most singular verifications of a dream which has ever come under our notice.

On Sunday morning, July 21st, 1872, soon after breakfast, while the vessel was erossing Georges, Capt. Elwell, not feeling very well, concluded he would go down below and "turn in." This be did, and, after getting asleep, dreamed that he saw a dead body afloat on the water. All his efforts to secure it proved unavailing, and it finally passed under the counter of the vessel. His dream seemed so much like reality, and his efforts to securc the body, and disappointment in not being enabled to do so, caused him to awake, and, upon going on deck, found it impossible to convince himself that he had not actually witnessed the scene so vividly portrayed in the drean. It made such an impression upon him that he felt intuitively that something out of the common course would soon occur. The crew, noticing his great uneasiness, asked the cause, and he told them of the dream, and they endeavored to convince him that dreams were nothing but fancies of the tired brain, and tried to withdraw his mind from the subject; but all of no avail.

About half an hour after the eaptain had come on deck, he no. ticed a box some distance ahead, floating upon the water. Upon sailing up to it he made endeavors to get it on board, but it eluded his grasp, and went under the counter of the vessel. They sailed on, but the captain was uneasy, and finally gave orders to put about, and secure the box. This was done, and, upon opening it, there was found the body of a little girl, about four years of age, who had apparently been dead some ten days. It was lying upon seaweed, 
with which the box was packed, and there were boles bored in the sides, which indicated that it was the purpose of the perpetrator of the deed, to have it sink. The box was of coarse hard wood, nailed securely, and it was evidently made for the purpose. As decomposition of the body had eommenced, and the ressel was not to return for several days, it was nailed up and sunk.

\section{SINGULAR PRESENTIMENT.}

Leonard Mailman, one of the crew of schooner Virace, of this port, died very suddenly, Aug. 31st, 1868, while the vessel was on Georges, from an attack of bleeling at the lungs, and while attempting to get into his berth, fell back into the arms of one of his shipmates, and expired immediately. Previous to his making the trip he had strong presentiments that he never should return alive. This he communicated to several of his friends, who enileavored to laugh the matter off and get it out of his mind ; but it was of no arail. So strongly impressed was he of his approaching dissolution, that, just before leaving for Georges, he wrote a letter to his brother's wife, with imperative orders that it should not be opened until she saw him again. He was brought back a corpse, and, on opening the letter, it was found to contain full directions in reference to the disposal of his effects, and other matters connected therewith, all of which were faithfully complied with.

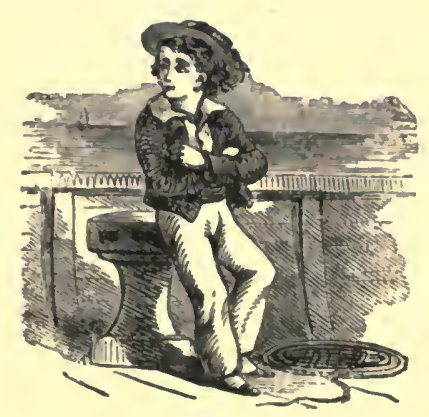




\section{Greenland and Iceland Halibut Fisheries.}

This branch of the fisheries was commenced, in 1870, by Capt. John S. McQuinn, of East Gloucester, who fitted schooner Caleb Eaton, of Boston, for a summer trip upon the coast of Greenland, in pursuit of halibut. Capt. AicQuinn made a successful royage, and arrived home in October, after about four months' absence, the vessel making a stock of about $\$ 20,000$. The success of the Eaton induced the fitting out of a fleet of six ressels in the business the next season (summer of 1871), but the vessels met with a small catch, 5,500 quintals in all, and one ressel, the River Queen, was lost on the return trip) with her crew of twelve men. Last year there were six vessels engaged in the business, meeting with excellent weather and a very fair catch, over 7,000 quintals in the aggregate, which brought good prices. This year four vessels are engaged in the Greenland fishery, schooners Aaron Burnham, 2d, William S. Baker, Caleb Eaton and $\Lambda$ lbert Clarence.

This season, 1873, has witnessed the inauguration of another new branch, that of halibut-catehing on the coast of Iceland. Capt. McQuinn, who had been so successful in the Greenland fishery, considered the chances on the coast of Iccland equally as good. The schooner Nembrino Chief was fitted out for this business, and sailed from this port the $23 \mathrm{~d}$ of May. They arrived on the fishing grounds on the 9th of June, but the weather was so unfavorable that they could not catch but six halibut and a few codfish. The vessel remained in Iceland waters five weeks, visiting various harbors and cruising on the fishing grounds whenever the weather would permit, but catching very few fish. Among the points visited on the coast wcre Underfiord, Patricksford, and Allevick, fishing villages, but Capt. McQuinn clid not cruise as far east as Reikiavik, the capital, where the governor resides. The weather proving so stormy through the carly part of July, affording such limited opportunities for fishing, that Capt. McQuinn determined to abandon the enterprise, and on July 11 th set sail for home, which he safely reached on the 13 th of August. The schooner William S. Baker, Capt. Albion Pearce, who sailed in company with the Membrino Chief, proceeded to Greenland, to make up a fare. 
From what we can learn respecting the Iceland fishery, the trip of the Membrino Chief was made in the wrong season. It is said that two schools of fish, which afford the best fishing, frequent the coast each year, one arriving in $\Lambda$ pril, and the other in September; thereforo this trip was too late for one, and too early for the other.

France employs quite a leet in the cod-fishery on this coast, which usually make two trips in a season. The English, also, have a few ressels engaged in it, and the Danes, to whom the island belongs, prosecute a large and profitable fishing business. It only requires another trial on the part of the Yankee fishermen to learn the modus operandi, and we should not be at all surprised if some of our skippers yet make successful trips to Iceland. Why not?

\section{Estimated Product of the Fisheries of Gloucester for the Year 1872.}

$\begin{array}{llllllr}384,000 \text { quintals codfish, - } & - & - & - & - & 82,016,000 \\ 67,395 \text { barrels mackerel, - } & - & - & - & - & 781,825 \\ 10,000 \text { " berring, } & - & - & - & - & - & 45,000 \\ \text { Other fish, } 25,000 \text { qtls., - } & - & - & - & - & 87,500 \\ \text { Shell fish, - - - } & - & - & - & - & - & 20,000 \\ \text { Fresh fish, } 8,000,000 \text { pounds, } & - & - & - & - & 250,000 \\ \text { Oil, } 225,000 \text { gallons, - - } & - & - & - & - & 129,000 \\ \text { Fresh herring, 2,540,000 pounds, } & - & - & - & 125,000 \\ \text { All others, - - - - } & - & - & - & 10,000 \\ \\ \text { Total, }\end{array}$

Toxwage. - The total tonnage of the District of Gloucester for the year ending June 30 th, 1873 , is $28,565.66$ tons, an increase of 16,982 tons over the previous year. The whole number of vessels is 517, employed as follows: six in the foreign trade; ninety in coasting; four hundred and twenty in fishing; and one yacht. 


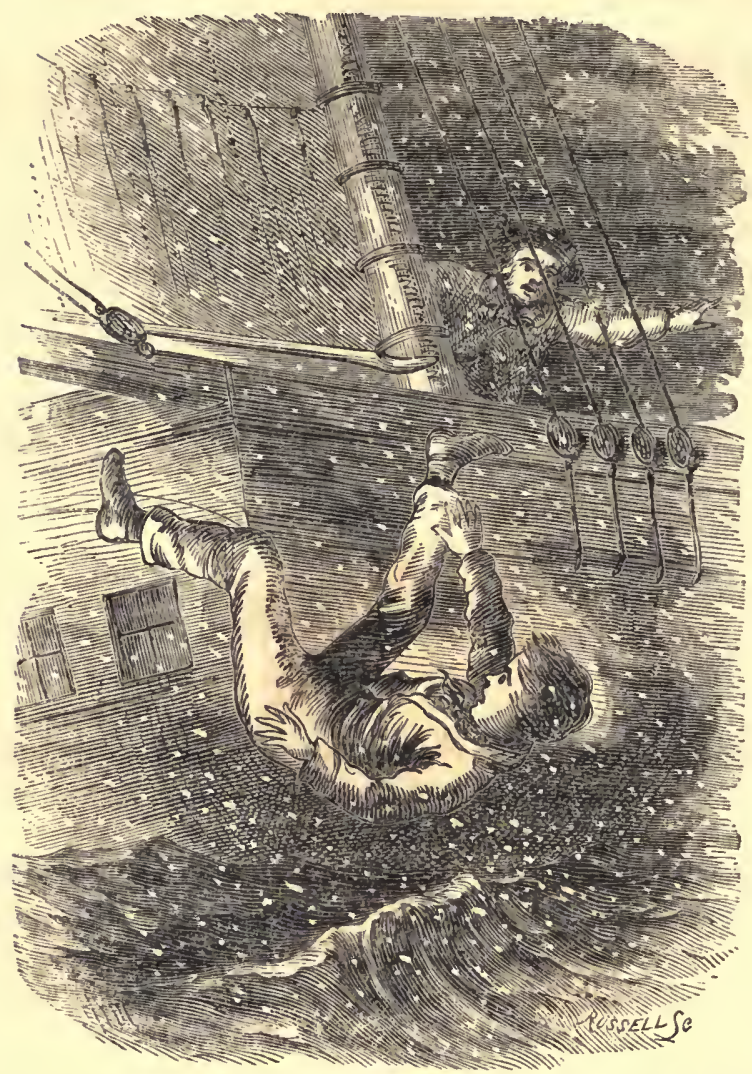

Remarkable Escapes of Schooners Onward and Seddie C. Pyle, on Georges - Loss of Schooners A. R. Andrews and Rescue of her Crew-Lost in the Fog - Rescued from the Jaws of Death.

On the night of August 2d, 1867, while the schooner Onward, Capt. Wilkes, was lying to on the western part of the bank, she shipped a heavy sea, which capsized her and carried away both masts, bowsprit and the upper-works, even with the deck. The man who was keeping watch stood in the companion-way, and, seeing the sea coming, jumped below, pulling over the slide in season to keep the water from pouring into the cabin. It is supposed that she rolled completely over, as, when she righted, part of the shrouds were under the keel, and floated on the opposite side. Some of the ballast also got shifted, and the fish were thrown underneath. Everything movable in the cabin and forecastle was thrown about in the greatest confusion. The stove was pitched into the cook's berth, and he narrowly escaped 
being crushed. A barrel of flour in the hold was tossed into the middle of the forecastle, and there was a general stirring up. Luckily the vessel shipped but little water, and, the hallast being pretty thoroughly stanchioned down, she soon righted again.

As soon as the gale had abated, the men proceeded to clear the wreck. The only articles left with which they could rig jury-masts, were the traveller, part of the topmast, and a small pole which had become entangled in the rigging alongside. These they soon riggel, and, taking their bed-clothing, improrised a suit of sails. Unfortunately the compass was found to be broken and useless; but Capt. Wilkes contrived to repair it so as to make it answer the purpose, and with these rude facilities they shaped their course for home, the wind being fair. On the passage they were fallen in with by schooner Matchless, of Boston, who offered to take off the men, but they determined to stick by the vessel, as there was plenty of provisions on board, and they were getting along very comfortably. On Saturday mórning, after a week's passage, they found themselves off Straitsmouth Island, where they spolie the Boston, pilot boat No. 9, Capt. John Bruce, who kindly offered to tow them into Rockport, which offer they thankfully accepted. She was subsequently towed to this port by the steamer Charles Houghton. Hundreds of people visited her, and she was pronounced by all the most complete wreck that ever arrived at this port.

Schooner Seddie C. Pyle, Capt. Richard Warren, was capsized in the gale of January 30th, 1870. She rode out the south-east gale handsomely, when the wind suddenly changed to the north-west, causing a heavy cross sea, one of which struck the schooner undel the quarter, and, breaking against the mainsail, threw the vessel on her beam-ends. The crew saved themselves by clinging to the side of the vessel. Fortunately one of their number had a large jack-knife in his possession, by which the main shrouds were cut, when the mainmast broke off and she righted nearly full of water. "The foremast was subsequently cut away, it having previously been broken off at the step, and did considerable damage to the forecastle and deck, before it could be cleared. The cable was then cut, and the crew proceeded to pump out the vessel, after which they rigged a jury-mast with the fore-boom, and, setting the jib and part of the foresail, steered to the westward. Having lost their fresh water, they were obliged to melt ice for a supply to drink, cooking their provisions in salt water. During the next eight day's they encountered several vessels at different times, and set signals of distress to each, 
some of which were so near that their names were almost visible to those on the wreck; but all passed without offering any assistance, until they fell in with the brig Almon Rowell, Capt. Atherton, who supplied the schooner with water, also quadrant, chart and epitome, and at the request of her master, took off five men of her crew, leaving five on board the vessel. The men taken off were landed at Holmes' Hole.

After parting with the brig on the 7th inst., all hands were busily engaged in getting the vessel in the best running order possible under the circumstances. A jury-mast was made by tree-nailing some plank together, and part of the foresail taken for a mainsail, which put the vessel in better sailing condition. They then run until eleven o'clock, with the wind N. W. by N., and it was judged they were twenty miles off Sandy Hook, which would have been reached if the wind had beld, but a sudden change took place, the wind veering round W. N. W., and at sundown it blew a terrific gale, accompanied with heavy snow squalls. The vessel was hove to and the gale continued three days, blowing them off two hundred and fortyfive miles S. S. E. from Sandy Hook. Barque Acacia was spoken on Friday, and assistance was declined. Had light wind from the southeast until five P. M., when it breezed up strong, and continued blowing until Sunday morning, February 13th. At noon they found by observation that they were in latitude 38.09 , with fourteen fathoms of water. At one P.M. schooner Emily A. Bartle, of Pbiladelphia, was spoken with, and, not wishing to be blown off again, signals of distress were set, which were promptly recognized, and they were towed into Maurice River, N. J. The names of the men who stood by the vessel and brought her safely to port, were Richard Warren (master), George W. Dexter, William Martin, Joseph Carter and John Shrader. They are well deserving of credit in thus risking their lives to save property.

Schooner A. R. Andrews, Capt. Maker, broke adrift on Georges, during the gale on Saturday night, March 6th, 1869, and was knocked down by a heavy sea. Her masts breaking off, she subsequently righted, and fortunately none of the crew were lost. Without any sail to steady her, she was driven before the tempest, the sea often making a clean breach over her, while the crew had to lash themselves in the most sheltered portions of the wreck to avoid being washed away. In this deplorable condition, the brig Como, Capt. Williams, from Messina for New York, fell in with them, and, after great exertions on the part of her crew, succeeded in saving the 
sufferers. They were blanched and frozen, with barely vitality enough to revive.

Schooner Charles Haskell had a very narrow escape from foundering. On Saturday night, during the same gale, dragged her anchors and was obliged to cut. While under sail, endeavoring to get clear of the lleet, came into collision with another ressel, staving her bowsprit completely through her, breaking it off, carrying away her head gear; then rising on a wave, struck her again, and it is supposed that she foundered, and all on board perished. The Haskell returned to port, and her disabled condition gave some idea of the violence of the shock. This is the only instance known where tro vessels have collicled on Georges and one has escaped foundering.

The gale of March 13th, 1870, proved quite severe on Georges, and the schooner Austerlitz, of this port, was so badly disabled that it became necessary to abandion her on the Banks. On Sunclay night, about eleven o'clock, she was boarded by a heary sea, when the cable parted, and the schooner falling suddenly astern, brought so great a strain on the rudder as to break the braces, and it was forced up through the arch-board, badly damaging the stern, and causing the water to pour in rapidly, when the vessel settled into the sea. No time was to be lost, as the schooner was fast filling, and.the crew went speedily to work and shifted the fish forward to lighten her aft as much as possible. The bulk-head in the cabin was then cut away to get at the leak, and all the bed-clothing stuffed into the apertures, which checked the flow of water considerably. By active work at the pumps the ressel was kept afloat until morning, when the sclooner Riverdale was spoken, and, on learning their condition, took off the crew.

John Maynard, of New London, and William Corthell, of Lyme, Conn., of schooner Gilson Carman, left that vessel on Georges, March 17 th, 1869 , in a dory, to haul their trawls, and, while doing so, a very heavy thunder squall sprang up, driving them from the Banks. They had at the time several halibut, and from sixty to seventy codfish, which they had to throw overboard, with the exception of one, which they retained to eat. After eating a little, it made them sick, and they were obliged to throw it away. On Thursday night they saw a vessel, but were unable to attract her attention; were drifting about all day Friday and Friday night, without anything to eat. On Saturday morning a duck lit in the vicinity of the boat, which they managed to kill, and ate it raw. On Saturday night, when they had nearly given up the idea of being saved, they male a light a few miles 
ahead. They immediately pulled for it, when it proved to be the schooner Henry Clay, of this port. During the time they were in the boat they had a steady storm of rain and snow, and were frequently capsized, but with the aid of a bucket they managed to keep the boat clear of water. Corthell had his feet badly fiozen. Mr. Maynard's arm was badly chafed and swollen, and both suffered greatly.

Lewis and Thomas Suratt, two of the crew of schooner Joseph Chandler, of this port, left the vessel February $27 \mathrm{th}, 1870$, to visit their trawls, when, a heavy breeze springing up, they were unable to return. The wind increased to a gale, and for twenty-four hours they were exposed to its full fury, narrowly escaping a watery grave. Thomas was once washed overboard, but his brother succeeded in getting him into the dory again, and they had about given up all hopes of being rescued, when they fortunately fell in with schooner M. L. Wetherell, of this port, Capt. Norwood, who took them on board and kindly cared for them. They were well-nigh exhaustel, and could have survived but a short time longer.

Two of the crew of schooner Robert Bruce, of this port, E. S. Johnson and Thomas Anderson, left the vessel on the Banks in a dory, May 3d, 1872, to attend their trawls. A thick fog set in shortly afterwards, and, losing sight of the vessel, they anchored their dory, in hopes of regaining the schooner the following day. The wind continned to increase, and about midnight the anchor line parted, when they determined to run to Seal Island, about fifty miles distant, it being the nearest land. Fortunately they had a small pocket compass, by the use of which they were able to keep the right course, and on Sunday morning they reached Seal Island, after forty-eight hours' exertion at the oars, without any kind of nourishment, haring tasted neither food nor water since they left the schooner. When they landed they were nearly exhausted, but were kindly and hospitably treated by MIr. Benjamin R. Hitchens, a resident of the island, of whom they spoke in terms of warmest gratitude. After resting for twenty-four hours, they started in their dory for Yarmouth, N. S., about thirty miles distant, where they arrived at noon. They had a very hard time of it, and, had they not been pretty plucky fellows, never would have reached home again.

Mr. James Dann, one of the crew of schooner Lottie F. Babson, had a very narrow escape from being lost overboard during the gale of March, 1870, while returning from Georges. He was on the boom, engaged in reefing the mainsail, when he lost his foothold, but fortunately in falling managed to grasp one of the reef-points, to which 
he held on until rescued from his perilous position by those on board. Had he fallen overboard, no earthly power could have saved him from drowning, as it was blowing a living gale at the time.

Richard Powers and George Welch, two of the crew of seliooner J. S. Sanborn, of this port, left the ressel in a Cory, June $16 \mathrm{th}, 1865$, to visit their trawls, and, a thick fog coming on, they were unable to find the vessel. Every exertion was made by those on board to find the missing men, but all to no purpose, and she returned to port without them. They wero subsequently pielsed up by an English vessel, bound to Pictou, from which port they arrived home in clue season.

The Ashing boat Garibaldi, Capt. George W. MIorgan, of Lanesville, engaged in the shore fishery, was caught in the gale of Tuesday, March 11th, 1872, off Ipswich, while attending to the trawls, and, being unable to carry sail, was soon driven asbore on Ipswich Bar, and sunk within two minutes after striking. Capt. Morgan had with him his partner, Mr. Levi Lane, and their only hope of escape was by clinging to the mast until assistance came. Hero they succeded, after much effort, in lashing themselves for their long and perilous watch through the night that was coming on, if indeed they should live to pass that wateh. Cold, benumbed and wet, with only a faint hopo of holding out, the long hours of the night passed wearily. At midnight they saw the keeper of the Ipswich light go and return from his duties; yet no help came. It now became a question of endurance. Capt. Morgan, becoming so thoroughly wet and benumbed, began to show signs of exhaustion, and must soon have perished. At length morning dawned, when the daughter of the lighthouse-keeper, Miss Susie Ellsworth, having, as it were providentially, risen earlier than usual that morning, saw the men clinging to the mast of their sunken boat. She immediately informel her father, who mustered a crew and went to their rescue in the life-boat. The men were taken to the house of $\mathrm{MI}$. Ellsworth, where they were very kindly cared for.

Two of the crew of schooner Lewis, of Marblehead, William Ward and Lawrence Mulcahy, left their ressels on the third of July, 18i3, to visit their trawl, and, a thick fog setting in, they were unable to regain ber. The schooner subsequently returned to port, and the men were given up as lost. The men stated that for five day's the fog was so dense it was impossible to see but a very small clistance around them. They made every effort to regain the vessel, but withont success. They frequently heard the whistles of steamers, but never saw one; and their sufferings for the want of food and drink were most 
excruciating. On the fifth day they were about to give up in despair, when the fog lifted, and, to their joy, they descried a vessel in the distance. This gave them new courage, and, determining to make one more effort for their life, they rowed for the schooner and soon succeeded in making themselves seen. The schooner proved to be the William A. Pew, of this port, and a boat was soon sent to their assistance. They were taken on board in a very exhausted condition, but, with careful nursing and kind attention from the captain and crew, they were soon on the mending hand. When they arrived at Marblehead they were welcomed by their friends as those only could be who had been given up for dead.

The Pinkey Nautilus, of Rockport, was about thirty miles abore East Point during the afternoon of October $3 \mathrm{~d}, 1851$, on which the terrible gale occurred in the Bay of St. Lawrence, and skipper Pool, not liking the looks of the horizon, told his men a tornado or hurricane was near at hand, and he determined to get the vessel into East Point, if possible. Shortly after starting, the blow came on, and it was indeed terrible. The wind fairly howled, so that it was almost impossible to stand on deck, or to hear a person next to you, let him scream at the top of his voice. The sails were close-reefed, and on the gallant little pinkey sped, like a racer over the course. She reached the bar, and it was feared there was not water enough for her to go over. To remain where they were was certain destruction, and the angry roar of the breakers, as they broke mast-high, was enough to appall the stoutest heart. Only one thing was now left for them, and that was to drive the vessel over the bar. It was a dangerous experiment, and the chances were as ten to one of its proving successful. The old skipper gave the order to let out the reefs, which was done; then right before it she drove, among the swirling, yeasty waters. Sometimes the craft was almost perpendicular, then she would thump, and touch; but still she kept moving, and those on board watched with bated breath, expecting every moment would witness the destruction of their vessel. It was a trying time; indeed, but imagine their delight, when the bar was passed, and the Nautilus was brought safely to anchor, her danger over, and her crew saved! Mr. James G. Tarr was one of her crew, and to him are we indebted for the incident. 


\section{The Pirate Tacony's Raid upon the Fishermen.}

The town was thrown into a most intense excitement on the morning of Wednesday, June 24th, 1863, by the announcement that several of the fishing fleet had been burned by a rebel pirate. The news was brought by the schooner Cadet, Capt. Williams, who arrived Tuesday night, having narrowly escaped being captured. He reported that on Monday, while at anchor in the South Channel, he saw a barque bearing down toward them. Having suspicions that she was one of the rebel piratical crafts which had been reported as cruising aloug the coast, he immediately hove up anchor, and there being a light wind, got his boats out and commenced towing her. While engaged in this, they saw several boats put off from the barque and board four other fishing vessels which were at anchor. A thick fog then shut them from sight, which gare Capt. Williams an opportunity to escape; a good breeze also sprang up, which greatly favored him, and he made the best use of these favorable auspices. That night he saw the light of four burning ressels, and while rejoicing at his own escape, his heart was full of sympathy for those of his comrades who had thus lost their vessels.

A director's meeting of the Cape Ann Mutual Fishing Insurance Company was called Wednesday morning, for the purpose of devising some means for the protection of the fishing flect. A committee of three, consisting of Messrs. Joseph O. Procter, Capt. Sylrester Cunningham and Epes W. Merchant, were chosen to visit Boston and have an interview with Governor Andrew, who advisod them to telegraph to Washington, which they did. Subsequently they visited the Navy Yard at Charlestown, and were informed by the Commodore that all the available ressels were on duty; but he would do all in his power to secure suitable vessels to be sent in seareh of the Tacony, and for the protection of the fishing flect. Another spirited meeting was beld in the evening, and a committee comprising Capt. Gorham P. Low, Joseph O. Procter and Benjamin II. Corliss, were appointed to serve as a committee to visit Washington and present a memorial asking for two small steamers to be commissioned for special service; one to cruise from Cape Sable to Cape Canso, and the other in the Gulf' of St. Larrence, for the protection of the fishing fleet during the season. 
The statement of Capt. Henderson, of schooner Marengo, is a fair example of how the fishermen were treated, which is, in substance, as follows:

On Monday morning at 7 o'clock, while all hands were engaged in fishing, saw a barque standing to the northwest; when she bore southwest from us she wore ship. A thick fog setting in caused us to lose sight of her, and we thought she was a merchantman bound in. Soon after, we were boarded by a boat's crew consisting of a lieutenant and nine men. Capt. H. went to the leeward to take the painter, and while making the boat fast the lieutenant jumped on board and grasping him by the back, exclaimed, "You are all prisoners to the Southern Confederacy!" and, drawing his revolver, shouted loudly, "that if any resistance was made, he would shoot them on the spot." Ten minutes was allowed the crew to pick up their clothing, then they were convejed on board the barque, when the Marengo was set on fire, and the fishermen gave a last look at the craft which had carried them safely through the summer's breezes in the mackerel fishery, and winter's gales on Georges. But there was no remedy, they were at the mercy of their captors, and any show of feeling on their part would have only resulted in making their situation the more unpleasant.

While on board the Tacony three others of the fishermen were burnt and their crews brought on board the barque, where they were all uniformly well treated. Capt. Henderson was invited into the cabin to supper, and the captain of the barque used lim very kindly, offering him a lientenant's commission if he would join the Confederate service. This of course was refused, as the patriotism of the New England fishermen during all the trying days of the rebellion was as firm as the rocks which form their rugged coast, and true to country were the bearts which beat in their manly bosoms.

On board the barque there were in addition to the crews of the fishermen, those of four ships which the Tacony had burned during the preceding fortnight, and as they were cramped for accommodations, the captain concluded to liberate the schooner Florence under bond, and send her to New York with the captured men. They were all put under oath not to fight against the Southern Confederacy, and with this parol were allowed to embark. The Florence spoke with the schooner Western Light, of Wellfeet, off Gayhead, and she took all the Gloucester men, landing them at Hyannis, where they were kindly received and forwarded home.

Schooners Thos. Woodward, commanded by Capt. John H. Welch ; 
J. G. Curtis, by Capt. Thomas E. Newcombe, and William S. Balier, by Capt. Albion K. Pearee, manned by our hardy fishermen, were at once fitted out and put into commission, to cruise in search of rebel pirates on our coast; but they had taken the alarm, and six ressels, as recorded in the year's losses, was the extent of the depredations upon tho fishing flect.

\section{A Valuable Branch of Industry.}

The fisheries have always been regarded as a raluable branch of the inclustry of Nerr England. From the early records of the Company of Massachusetts Bay, we learn that our fishermen were among the few classes of persons who were exempted from the performance of military duty. So important were the fisheries considered in old colonial times, that, in negotiating for peaco with the mother country, MIassachusetts desired no peace unless it secured to the United States the freedom of the fishing grounds.

As an evidence of this sentiment, the carved codfish was conspicuously placed on the walls of the State House; which remained there until a very recent period, and may still, for aught we know, adorn the Capitol at Boston; not, perhaps, so much as a work of art, sinply, but as a rerolutionary memento, serving to remind the assembled wisdom of the Commonwealth, annually, of the self-sacrificing and determined spirit of their predecessors. 


\section{Recapture of Schooner E. A. Horton from the Cus- tody of the Dominion Government - A Daring Act by a Yankee Skipper and his Crew.}

The seizure of American fishing vessels by the officers of the Dominion Government, for alleged violation of the old treaty which restricted our fishermen from pursuing their calling within an imaginary three-mile line from the Canadian shores, caused a vast amount of ill-feeling during the seasons of 1870-'71, and '72, as well as in previous years, when attempts were made to enforce it. The annoyances which the officers of the Dominion cutters heaped upon unarmed fishermen, and the flimsy pretexts under cloak of which they would seize the vessels, was a disgrace to any nation making any pretensions to civilization, and the apathy with which our government witnessed these dastardly insults to loyal subjects, was equally disgraceful on the part of those in authority.

Schooner E. A. Horton was scized about the first of September, 1871, and taken into Gussboro', there to await the decision of the Court. Her owners, Messrs. McKenzie, Knowlton \& Co., had been subjected to great inconvenience and expense by the unfriendly Canadians, who captured one of their vessels the year previous, and finding that there was no chance for redress before the Dominion courts, they determined to depend upon themselves and take possession of their property wherever found. To this end Capt. Harvey Knowlton, Jr., one of her owners, left town Sept. 20th, and arrived at Manchester, four miles below Guysboro', Sept. 27th, and in order to get an opportunity to fully develop his plans, and to disarm suspicion, went to mining, and obtained several specimens of gold quartz. After four days at this occupation, he took his specimens and went to Canso. Here he worked very quietly and secured the services of six American fishermen, viz. : Daniel Richards, John Penney, Charles Webber, D. Isaac, Malcom McCloud, and Peter Gillis, who cheerfully volunteered in the enterprise. October $3 \mathrm{~d}$, Capt. Knowlton and his men left Canso and travelled through the woods, a distance of eigliteen miles, to Guysboro'. This occupied the entire day, as they were often obliged to hide themselves in order to escape observation. Arriving 
in Guysboro' after clark, they concealed themselves in a barn, having taken the precaution to procure a good stock of provisions. Capt. Inowlton kept himself constantly disguised, and employed his time in reconnoitering around the town, visiting the wharf where the vessel was moored, sounding the channel, and in obtaining such other information as he would require when the moment for action arrived. He found that the officials were so sure of their prey that they had no lieepers on board of the vessel ; but she was stripped of sails, rigging, etc. The captain made good use of his eyes and ears during his stay in town, and found where these appurtenances were stored. His men kept very quiet in the barn and were not observed by any one. They were, however, as might be expected, impatient for action.

Sunday, October 8th, was the time set for the recapture of the ressel. At half-past nine o'clock it was bright starlight, with a favorable northwest breeze blowing. Tho captain and his men len their hiding place and boldly walked into Guysboro', a distance of six miles, and were fortunate cnough not to meet any person on their way. They arrived at the centre of the town just as the clock on the church steeple pealed forth the hour of eleven. Observing some lights yet burning in the houses, they waited patiently until these were extinguished, and then proceeded to the wharf. They were not long in putting themselves inside of the building which contained the Horton's sails, rigging, etc. These they took charge of and soon had them on board the ressel. Finding they had made some mistake in the sails, having got some belonging to another vessel, they were obliged to return them, which caused a vexatious delay. It could not be helped, however. The vessel was aground, but the tide was coming in; her sails and rigging were quickly bent, and all was ready for starting at one o'clock. The suspense was terrible, as the appearance of any person on the wharf, to raise an ulurm, would defeat the entire plan. Fortune favors the brave, however, and it would have been a big fight if the captain and his men had been opposed at this point of their proceedings. All was ready, but it was found that the craft was yet agrouud. Time was precious now! A warp was got out and the ressel was hove astern. At half-past two the joyful fact that she floated, became apparent. All was still. Not a word had been uttered, nor an unnecessary sound made during all these preparations. Sail was put on her, and with Capt. Knowlton at the helm, the saucy little craft filled away, and showed a "clean pair of beels" as she passed out of the harbor, at liberty, and released from the hands of a government which has made itself particularly obnox- 
ious to all civilized communities. The surprise of those having the Horton in charge, as well as the good citizens of Guysboro', when they awoke on that eventful Monday morning and found that Yankee fishermen had been at work while they slept, and had taken possession of this captured fishing vessel, can be imagined better than described.

It was apprehended that pursuit would at once be made, but the captain had made his calculations to elude it. At daylight the vessel was outside of Little Canso, and her course was shaped S. S. W. in order to obtain a good offing. There was a fresh breeze from the N. N. W., and by sundown she was many miles outside of land, with her course shaped for the northern edge of the Gulf Stream. There was plenty of water and provisions on board, as the ressel had been refitted only two clays before being taken by the cutter. This was not known for a certainty, but had to be risked, and fortunate indeed was it that the officials had not removed these important sinews of war. The southwesterly course wast pursued until the 11 th, when a severe easterly gale was encountered, in which the - vessel's foresail was badly damaged. Saw one steamer on the third day out, did not speak any vessels, but was continually anxious for fear of being recaptured. The captain had made up his mind that the vessel should not be retaken, and in case an English cruiser molested them, preparations were all ready to burn the Horton. The course was continued across the southeast part of Georges Banks, and then direct for Cape Ann, the vessel arriving Wednesday evening, October 18 th.

The passage was made without any charts or nautical instruments, with the exception of the compass, the captain relying entirely on his own judgment in shaping his course.

\section{EXCITEMENT PREVIOUS TO HER ARRIVAL.}

The Monday previous to the Horton's arrival, a rumor prevailed here in town that an English 'war steamer was cruising in the bay, for the purpose of intercepting and capturing the fugitive schooner. But very few credited such a sensational rumor, but as there was a probability that such might be the case, Collector Fitz J. Babson took immediate measures to insure protection to the IIorton in case she should be waylaid. He at once corresponded with Collector Russell, of the Boston Custom House, and suggested that an American government vessel be sent to watch the movements of the Englishman, and prevent any outrage in our waters. He also telegraphed to Portland to secure the services of the cutter McCulloch. In the afternoon, during the absence of Collector Babson in Boston, on business 
connected with the department, B. H. Smith, Esq., Surveyor of the District, telegraphed to the commandant of the Charlestown Navy Yard, for a gunboat, and reccived reply that $n$ vessel would at once be sent to tho assistance of the Horton. During tho evening the supply steamer Fortune, armed with two howitzers, arrived here from the Navy Yard, and started in search of the supposed cruiser, taking Mr. Robert MIclienzic, one of the owners of the schooner, and Capt. Robert Tarr, who was specially authorized by Collector Babson to take charge of the Horton if they fell in with her, in the name of the United States, and hold her as a derelict vessel, being found without papers, and bring her into port. The Fortune, after cruising all night and Tuesday forenoon, returned, having failed to obtain any information in regard to the cruiser. Her place was supplied by the steamer Leyden, which cruised in the bay on Wednesday, in search of the Horton.

Early on 'Tuesday morning, the cutter Mahoning arrived here from Boston, accompanied by the revenue tug Hamlin, and both vessels procecled in search of the Ilorton, with instructions to allow no vessel to interfere with her, but to bring her into port ht any hazard. Collector Babson also received a dispatch from the Collector at Portland, stating that the cutter MeCulloch had sailed in seareh of the vessel. But nothing was seen of either English steamer or the Yankee fishing schooner, whose arrival was looked forward to with the most intense anxiety, not only by our people, but all along the New England const.

ARRIVAL OF THE HORTON - IER RECEPTION - DEMONSTRATIONS OF JOT.

On Wednesday evening about Lalf-past seven o'clock, the booming of cannon at Rocky Neck announced that the Horton had arrived. The news quickly spread through the town, and there was general rejoicing. Guns were fired, the bells were rung, and Young America paraded the streets with drums, horns and toreh-lights, firing pistols, and having a general jollification, which was kept up till midnight. Large crowds of people wended their way to Rocky Neck during the crening, and Capt. Knowlton and his brave crew were heartily congratulated upon the suceess of their bold undertaking. The fishing owners were joyful over the event, while the fishermen gave vent to their delight in the most enthusinstic manner. Interviewers for the press were numerous, and dispatehes, as per agreement, were immediately sent from the Advertiser oflice to the Nerw York IIerald and Boston Post, giving the glad tidings of the safe arrival of the ressel. 
All over town the cry was heard that the Horton had arrived, and the event was made the occasion of a general jubilee. The Gloucester Cornet Band was promptly on hand, and after performing several stirring national airs on Front street, proceeded to Rocky Neck, escorted by the torch-light procession and a drum corps, and serenaded the gallant Capt. Knowlton at his residence, who duly acknowledged the compliment. Notwithstanding the blustering, disagreeable weather, crowds of people joined the procession, giving vent to their enthusiasm by hurrahing, firing guns and sending up rockets. It was an evening long to be remembered. Salutes were also fired Thursday morning and evening. There was also a display of fireworks, and the band, accompanied by a large procession, paraded the streets, playing patriotic airs. At eight o'clock a congratulatory meeting was held at the Town Hall, which was filled to its utmost capacity.

Benj. H. Corliss, Esq., was chosen chairman, and made a speech, reviewing the many grevances of our fishermen, and the persistent course of aggravation and aggression maintained by the Dominion Government. He was followed by B. H. Smith, Esq., and others.

Mr. Corliss presented Capt. Knowlton and his crew the sum of $\$ 1,000$, which had been subscribed by the citizens of the town as a mark of esteem, and a slight testimonial of the great service they had rendered the fishing interests in thus daring to take possession of the Horton.

The speaking was interspersed with music, and the meeting was a lively one in every particular, and fully demonstrated the sentiment of this community on the fishing question.

\section{THE HORTON WAS NEVER GIVEN UP.}

It was supposed that the British government would make active efforts for the return of the Horton, and would petition our government to that effect; but nothing of the kind was done. Collector Babson at once applied to the Secretary of the Treasury for another set of papers, on the grounds that the United States government had no claim upon any vessel coming into port having lost her papers. The vessel he considered in the condition of one served by due process of law, and a keeper placed on board. On the departure of the keeper or guard in the fancied security of insufficient water to float the craft, her owners were at liberty to go on board and assume possession. No violation of law had been committed, as the vessel was virtually abandoned by the officers who had her in charge, and no violence was used in her recapture. 
There was some correspondence between the Canadian and British Governments relative to the seizure of the Horton. This was in clue season laid before the House at Ottawa. The first paper was a memorandum from the Dominion Council to Earl Iîmberly, stating that the prize money should bo forfeited on account of the gross carelessness in guarding the vessel. The question of indignity to tho flag, it was recommended, should be lent to the Homo Government, as it more properly came under their jurisdiction. The Committee of Council also reported, that under tho circumstances, they did not feel called upon to recommend the reclamation of the ressel by the Dominion Government. Earl Kimberly expressed himself satisled that such dignified conduct would serve to promote friendliness with the United States, which was the earnest desire of England.

'The excitement of the Horton's recapture continued several weeks, as it was rumored that efforts would be made to run her out some night. Every precaution was taken to guard against this, and the plans were so well laid that it was absolutely certain that the vessel could not have been taken out of this harbor. Tro of the local poets gave very vivid and interesting descriptions of the Horton affair, and the effect produced upon our people, which are well entitled to a position in this narrative.

\section{"THE HORTON'S IN."}

$$
\text { BY "OLD LOCALITT." }
$$

The day retired serene and fair, And llghts came glanchng hero and there, While gently swung the twiligbt down On Rocky Neck and Gloucester Town.

The pulse of buslness life ras still, From Gardner's Brook to Beacon IIII, On wharf and fish-yard, beach and bay, The calmness of the erening lay.

Boom! and a cannon's rolce rang out; Boom! and a mingled cheer and shout, With drum and trumpet, strelled the din "The Iortou's ial the Ilorton's in !"

Safe from the Hou's angry paw, Safo from the lapdog's snapping $\mathrm{jaw}$, IIurrah I Cape Ann is bound to wh "The Ilorton's In! the Iorton's In!"

IIurrah | hurrah | rose loud and shrill, From Dnnean's Polnt to Banner Hill; And Front and Park and Muddle streets Passed on the tdangs wild and fleet.
Hurrab! burrah ! for Yankee wit, Ilurrah ! hurrah! for Cape Ann grit, It's pluck and dash that's sure to win "The Ilorton's in | the Ilorton's in |"

Here's three times three for the Captain, then, And three times three for hls gallant men; For the strong and darlng, free and brave, The ollve-branch and the lanrel wave.

\section{ESCAPE OF THE HORTON.}

$$
\text { BY "TANKEE NED." }
$$

Under the canopy of blue, Under the starlit $8 \mathrm{ky}$,

They crept - the daring, manly crew To cut her ont, or diel

Into the store they climb, Wlth darkness all around;

Their nimble fingers quickly find That every sail is sound.

Wlth hank and halgard stout, Her wings were bent anew -

Those gallant lads they ran her out Across the waters blue. 


\section{FISHERMEN'S MEMORIAL AND RECORD BOOK.}

Away from 8cotla's shadowy shore, With cruisers on her lee,

She travels o'er the deep once more, To Cape Ann's port - she's free!

Old Eastern Point is dead ahead, And the skipper's home in sight,
With flying colors she is sped Safe into port at night.

The spirit true of'seventy-six Lives in the land to-day;

Thank God! - and no Dominion cligues Shall bar the Yankee's way.

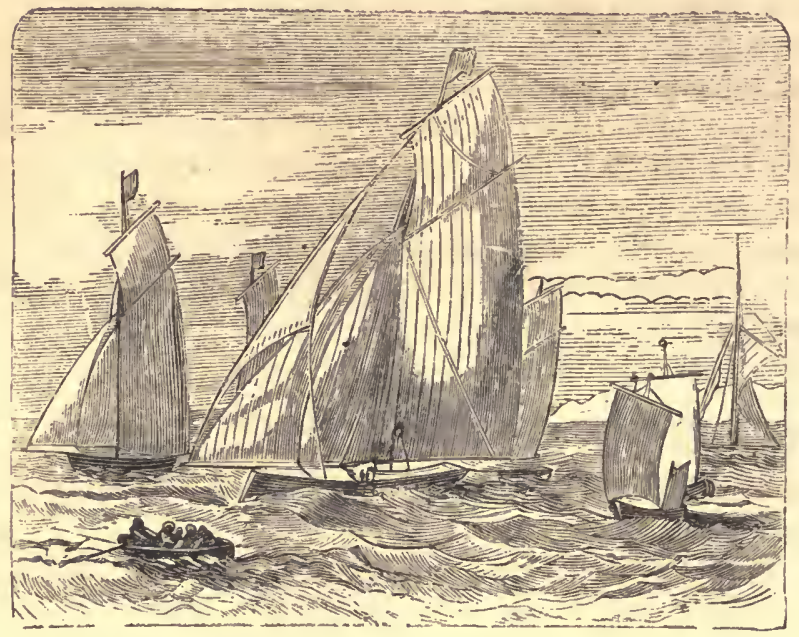




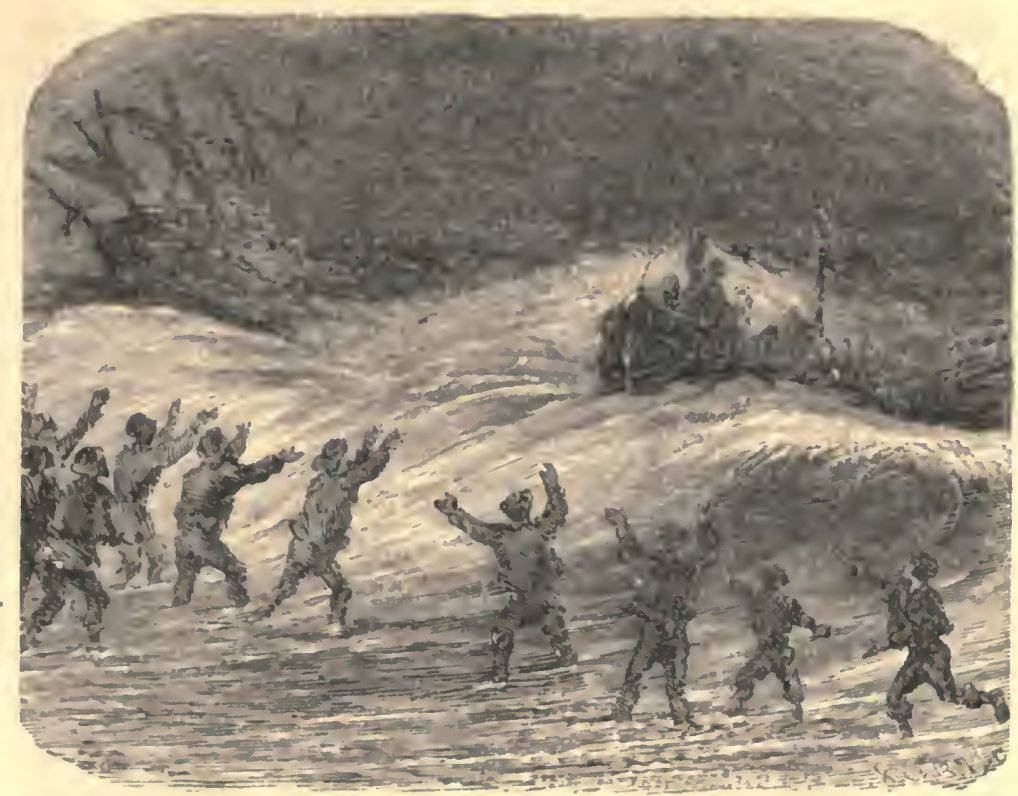

\section{The Severe Storm of 1839.}

The most distressing event which ever occurred in our harbor was occasioned by the storm of Sunday, December 15th, 1839. From one of our citizens, who witnessed the fury of the storm and watched the doomed ressels as they dashed on the rocks, we glean the following particulars :-

Saturday, the day previous, was remarkably mild and clear for the season. This induced the inasters of many of the Eastern ressels to leave port on their trip to New York, Boston, and furtlier southward. Arriving off Cape Ann, the wind suddenly reered into the soutl-enst, with every indication of a violent storm. Sixty-five of the ressels sought refuge in the harbor, where, in the course of the uight and Sunday forenoon, they came to anchor. At noon, the wind blew fearfully, and in the afternoon increased to a terrific gale, with snow and rain, and one of the roughest sens running which had crer been seen on this coast. Its power was indeed terrible; and the flect of coasters were watehed from the shore by our people with the most intense anxiety, as they knew, if any of the vessels got adrift, there would be need of help to sare lives. 
The prospect, however, was a cheerless one, as there was but little hope of the lives on board the vessels, if they once got into the terrible breakers of the lee shore. Along about three or four o'clock the vessels began to go adrift, and the scene was one never to be forgotten by the large crowd who bad gathered on the beach. Many a silent, heartfelt prajer went up from that throng, in behalf of those whose lives were in such imminent danger, to aid which, human arms were almost powerless. Some of the ressels sunk at their anchors, and all hands perished. Others came upon the rocks, where, with the assistance of the strong arms of men who had baffled with the storms for years - the hardy fishermen and seamen of our townmost of the crews were rescued. All that afternoon the vessels continued to drift ashore. Many were saved from this calamity by cutting away their masts. Darkness came down over the scene, rendering it all the more dismal, the wind howling and the sea raging piteously all through the hours of the night. Twenty wrecks were strewn along the shore ere the night had come on, and the morning's dawn was watched for by men who were determined to do all within their power toward saving the lives of those so terribly exposed. The gale abated somewhat during the night, and the faint streaks of light which glimmered on the eastern horizon that Monday morning revealed to sight thirty dismasted vessels riding at anchor in the harbor. The wind veered round to the north-east the next day, and as it moderated, Capt. William Carter, with a volunteer crew of noblehearted men, put off in the Custom House boat, and brought the men ashore. They were obliged to jump on board, as it was too rough for the gallant little craft to board the vessels. One of the vessels, just as her crew was taken off, drifted out of the harbor, and was never heard of afterwards. A most miraculous escape, indeed.

Everything that sympathetic men and women could do was done for the comfort of the living and for the recovery of the bodies of the dead. The exact loss of life was never fully ascertained, but including those who perished on the wreck near Pigeon Cove, twenty lives were known to have been lost in this vicinity. Some of the bodies were taken away by friends, and the remainder were buried from the Unitarian Church on the following Sunday afternoon. All the other churches were closed, their pastors taking part in the funeral services. An appropriate sermon was delivered by Rev. Josiah K. Waite.

The storm occurring at a season when the fishing fleet were hauled up, did not cause any loss of lives or property of our people, which was indeed a most fortunate circumstance. 


\section{Fishermen's Children Playing on the Beach.}

We remember reading somewhere in a book of dreany fancies that the thoughts of ehildren are long, long thoughts. They reach out a great ways, and full of daring, venture into paths that we older people, made practical by the world, are afraid to tread. $\Lambda$ child's thoughts, if we could but know them, would make the prettiest fairy story ever told.

Theso two fishermen's children playing on the beach of a sunny afternoon have turned their backs to the sea. It looks, one might fancy, as if they had turned their backs to the sunshine of life, and were looking boldly out into the darkness. But their eyes are so bright, being yet unclonded with sorrow, they can well afford to face the shadows for a time; their sight is strong. The boy's fuce is full of daring; we can sce that, with his brown, bare arms crossed, and his hat well pushed back from his forehead, he is telling his playmate a marvellous story. Perhaps he imagines that he is a bold skipper and has gone in his vessel on a perilous royage.

"The fleet dropped anchor at the Banks," he says, "and the wind blew great guns. You'd ought to seen the snow drift, Matty. But I stood at the rail and hauled in Land over hand. My! didn't we have a splendid catch? An' then we up anchor 'an' drifted - an' drifted out of sight of all the others. Two of the ressels went down, but we got safe into port after a while; and then, wasn't there a shouting! You'll never go on such a trip, Matty, for you're only a girl!"

We can imagine how the girl's brown cheek flushes and her bright eye kindles as she answers, after a moment's hesitating thought :-

"Well, if I'm only a girl and can't go to the Banks, I can stay at home and wait and pray for you to come safely back again."

She scems very young to have found out that a woman's destiny is to watch and wait for a loved one's coming.

The scent of a seaport town is in this little picture. The ressels glide away in the distance; the sea and sky are all one, they are so smooth and blue. We get the scent of tar and fish as the rind blows in over the stones and twisted ropes, searreed and oars. But the children hare turned their backs to all this, and are living in a world of their own. The girl's face laughs through its sweet dreaminess. She looks as if she trere turning over in her mind something the boy has said. Perhaps, she don't quite believe his story, although 
a lassie is mostly quick enough to credit the wonderful things a lad tells her. He is telling her, now, what he shall do when he grows up.

"Most likely I shall go to Greenland, and then to Iceland, and shall own ever so many vessels. Will you stay here an' watch for me when I'm out, just as we watch for our papas, Matty?"

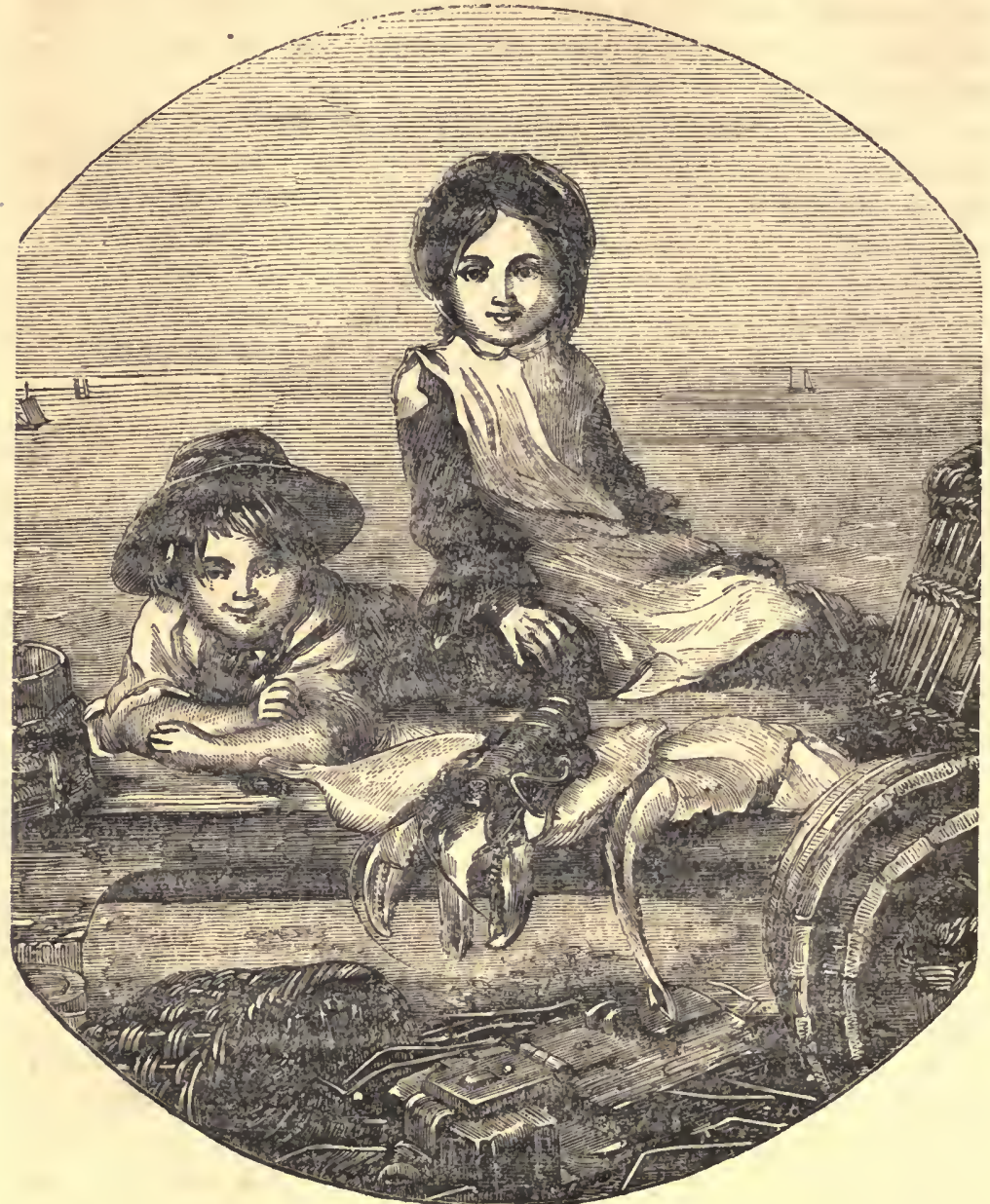

How her dark eyes glow! How she believes every word that this little adventurous fisher-boy tells her, and how meekly, yet brarely, she accepts her own destiny of watching and waiting at home on the beach! 
"You'll be a strong man, won't you, when you grow up?" sho says.

"Yes; and I'll buy you a pretty new dress, and ribbons every year," he answers.

After all, it is not much they ask for of life, as they sit dreaming and playing on the beach. He will have his vessel, will make stormy trips to Georges and the Banks ; and leave wife and children waiting and praying for him at home. The girl's fancies will always keep bright and warm. She will have a house of her own, with neat, painted foor, and pretty white curtains and quilts, and flowers at the open window in summer. And by and by, when she waits on the beach, her face will be turned torrard the sea, not from it as now, aud she will be watching for the coming of the loved onc's vessel safe home after the storm.

The thonghts of youth are long, long thoughts. They flow out in strange, sweet ways; they tell a thousand different stories, all in different tones; they make a fairy land for ehildren to dwell in. Perhaps we have not guessed this boy and girl's thoughts aright; no doubt they are a great deal brighter than anything we can imagine, and if we follow them very far, wo shall be obliged to stop and rest. We know that they are bright and boundless as the sea that lies behind them, for we can see the reflection of them in their happy faces.

\section{The Cape Ann Fishermen of To-day.}

Those who man the fishing ressels of to-day represent all nationalities, and present a marked contrast to the fishermen of a quarter century ago, when they were composed mostly of uative-boru citizens. The business has since that time increased so rapidly that it becrme necessary to look elsewhere for men. Very naturally the supply has been obtained in great numbers from the Provinces, and Nora Scotians represent a large majority. of the men now pursuing the rocation. Among them may be found some of the smartest slippers of the flect. These have made gool use of the opportunities presented, and by their good.qualities as seamen, capacity to handle a vessel, and possessed with sufficient daring to run the risks of winter-fishing, they have attained good positions. Many of them, who came here with scarcely a dollar in their pockets, are now owners, or part owuers, of vessels, showing an energetic spirit of industry and perse- 
verance, which has surmounted difflculties and brought, as a reward of their toil, good returns.

These men, as a class, are naturally fitted for the business. Born' and reared by the sea, most of them of poor parents, it became a necessity for them to earn their own living at a very early age. Fishing was about the only occupation in which they could engage in the Provinces, and in this branch they commenced, bringing to it all the energies of youth, and by its pursuit laying the foundation of robust health, which enabled them to bear the toil it demanded, and preparing them for the more advanced positions which were offered on board the American fishing vessels.

The yearly visits of our fishing fleet into the Provincial waters show these men the contrast between the two classes of vessels, Nova Scotian and American; the one, clipper-built and well appointed in every particular, and the other, clumsy and far behind in all the modern improvements and fittings. It is not strange that they had a desire to connect themselves with the better class of vessels, where opportunities for becoming masters and owners were so temptingly held out as the reward of industry, fidelity and daring to venture for a trip of fish at the most dangerous and inclement seasons of the year. They caught the inspiration of the Yankee fishermen, as they associated with them in their summer visits after mackerel, and learned of the winter fishing on Georges and the Banks ; of the chances to make profitable trips; the opportunities to get ahead in the States; and the advantages for their children to obtain an education. They also learned how well the vessels were provisioned. All this led them to seek for chances on board our vessels, and we have drawn from the Provinces hundreds of her population, representing all grades, with a good proportion of really valuable men, who to-day are numbered among the energetic and thriving citizens of the town.

In addition to these are the Portuguese, who also form a considerably large percentage of the fishermen of to-day. They make good stewards, being industrions and very fond of the perquisites which fall to the lot of those who hold this position, receiving not only a full share with the men, but additional compensation for their services, and other privileges which they are not slow to take advantage of. As a class they are very industrious, very prudent also, looking sharp after the nickels, fully believing in the adage of taking care of the cents, as the dollars will take care of themselves.

They are mostly natives of the Western Islands, are quite clannish, 
ardent Catholics, and very fond of pictures representing their patron saints. There is quite a settlement of them in Gloucester, and, taken as a class, they are industrious and law-abiding citizens. Many of them own houses and are well-to-do in the world.

Then there is quite a sprinkling of Irish, Swedes, Norwegians, and Danes; in fact, every nation on the face of the earth is represented among the fishermen. Among them are men of education, who by their gentlemanly bearing betray their good-breeding, and by the class of reading matter they select, are at once known as men of culture. "How did they become fishermen?" asks the reader. There is but one reply. Something went wrong with them at home; as, for instance, the case of an Englishman, who followed the business for twenty years in succession, as steward, - and a good steward he was. His father was wealthy, had a good position, and this son George had a brilliant future in prospective. He loved a girl moving in his own station in life, and they were betrothed. IIe staked all on her whom he so fondly loved. She trifled with him, oftentimes cutting him direct, and finally encouraged another suitor, a man of the world, who seduced her. The rest is soon told. George lost all faith in humanity - the world looked dark to him. He left England as a common sailor, came to Boston, and from thence drifted down to Gloucester, where he followed fishing. He never returned home. One winter evening, as he sat with us in our sanctum, he told us the story of his life, and as he related it the tears rolled down his cheeks, at the contrast from what he was, and what he might have been, perhaps, with a family around him, if the girl of his beart had only proved true and returned the love which he had so freely bestored.

He has a snug competence, and the evening of his life is passed in quiet contentment. No more he follows fishing, or ventures on Georges in midwinter; but amid the quiet of a family boardinghouse, he is awaiting the summons which shall call him to that home beyond, where there is no more sorrow.

Another we call to mind, a Swede; a man of commanding presence, bold as a lion, a good navigator, and, if he had let rum alone, would have made his mark in the world. But, alas! he was a slare to appetite, and the noble attributes which God had given him were prostituted. None knew this any better than he, and yet he would drink, and one night his body. was found in the harbor. Many a tear was dropped as his remains were prepared for burial, and then we lnew that the bottle had obtained one more victory - had secured one more victim. 
The old-lime skippers are fast disappearing from the decks of the fishermen. You will find them engaged as fitters-ont and owners. Knowing the business in all its branches, it is not to be supposed that tley are to follow the hook and line all their lires. No, indeed! They place their son or some other competent person in command of the craft, aud, becoming owners or part owners of cther vessels, launch ont into the business, and become tlie solid men of the town, who may be.seen at the meetings of the Gloucester Fishermen's Insurance Company, or gathered each evening in the reading-room, discussing the fishing news, and giving their opinion of the market and the prospect of a good year's work. Right well are they deserving of their positions, as they have earned them by continued toil, when with their lives in their hands they left the home-port behind and sought for a trip of fish, when the winds howled and the sea beat with its fury against their craft, threatening to swallow it up and bury them far down in ocean depths, where so many of the brave fishermen have found a grave, and the loved ones on shore have waited so patiently for their return.

The fishermen, God bless them, whether on the land or sea! Theirs is a life of toil ; and although fortune smiles upon them occasionally and sends a good school of fish, jet they spend hours and hours at the rail, in the bitter cold of winter, waiting for a bite ; - " grubbing," as it is termed, - with a family at home, whom they love as wcll as any one loves their own; and the bread of this family depending upon the catch of fish. Oftentimes these fathers will lie awake at night in their berths, tossed up and down by the waves of Georges, hoping that he may do well this trip for the sake of his loved ones who are in need of many things for their comfort. This is no fancy picture, but the earnest facts in the lives of the married fishermen, who cannot stay at home in winter, because there is bread to win; and they must win it. All honor to them. Theirs is no holiday existence, but a continued grappling with the elements, a struggle for life, with storm and old ocean in its anger to meet, and with pluck and daring, they wring success from the very verge of the grave. 


\section{How Harry G. came to Sign the Pledge.}

Harry G., ol "Jolly" Harry, as he was sometimes called, was a noble specimen of a fisherman, being active to duty when on boari the vessel, of good disposition, possessed of a fair education, and had rery many noble traits in his character which endeared him to lis shiprnates.

He had one fault, and that was a bad one, - he would drink liquor aud oftentimes get intoxicated; and when in this state he was fleeed of his hard earnings. Consequently he was always poor and belind-hand. Rum so got the better of him at last that it was evident that he was fast going under.

One night in February, Irarry was ashore. He had come in that day from Georges with a good trip, and having got a little money on account, he drank it all up and was very nearly intoxicated, when in the midst of a driving snow-storm le started from the old Fort Wharf, to go on board the vessel which was lying in the stream. The liquor had begun to work, and as Harry was sculling his boat, he fell overboard. IIe was a good swimmer, and the cold bath sobcred him. Now; thought IIarry, as he told us afterwards, it's life or death with me. If it had not been for rum, I should not bave been in such a predicament.

The cold water struck to his very vitals, and with great dificulty he kept afloat. Finally, by the merest chance in the world, he got hold of the rudder of his ressel and held on for dear life. Then he began to shout for help; but the wind drowned his roice and the cold made him shiver. He heard the old town clock strike twelve, and then he began to fully realize his situation and the danger he was in. There came up before his vision the sainted face of his mother, who had, jears ago, gone ou to the better land. She seemed very near to him that night, and we may call it fancy or not, his dear mother actually seemed to be with him, and called him her darling IIarry, as she was wont to when he was a lad. He sam that clear faec, which he remembered as last having gazed upon in the cofin; he saw the smile which was so dear to him all along his youthful journey, and then he heard her speak. This was what she said : -

"My darling IIarry, your mother from her home on high comes to you this night in your perilous position, and asks, if she will get you safe from the danger which threatens, that you will quit drinking liquor and nerer touch it again." 
All this did not take but a moment, so Harry said; and he told his mother, or what he solemnly declares was his mother's spirit, that if he escaped that night, he would sign the pledge and keep it.

The next thing he recollects, was the skipper, leaning over the vessel's stern and asking who it was that hallooed? Harry explained the situation, and was drawn on board more dead than alive. $\mathrm{He}$ went into his berth and all night long dreamed of his mother. Up before his vision there came the days of his happy childhood, and then gradually came the changes, and the word Liquor seemed posted up all about his berth, and then came the word RuIN. TuE PLEDGE Is YOUR ONLY SAFETY then appeared in letters of gold. When he awoke in the morning it all came back to him: the fearful position, clinging to the rudder; his mother's voice and presence. He dwelt upon it all day long as he walked up and down the streets. His companions often invited him to drink; but he steadily refused, although his appetite craved it in a most violent manner. He kept his thoughts on his last night's peril, and did not enter a rum-shop for the day. After supper he tidied himself up as well as he could and called upon a good-hearted deacon, who had at one time talked to him and entreated him to leave off drinking. He met with a most cordial reception, the good old deacon at once giving the poor fellow his sympathy and support. Ere Harry left the house he had signed the pledge, and by the memory of his mother's words that night he was enabled to keep it. They acted as a talisman whenever he was tempted.

Life was far different to Harry after signing the pledge. In two years' time he was skipper of a ressel; then he became part owner; then he married a woman every way worthy of him. He is in the better land now, and his last days were happy ones. A few hours ere his spirit took its flight, he told a comrade who was watching by his bedside, "that the happiest memory of his life was, that he had never broken his pledge. Soon I shall be with my dear mother, and as I grasp her hand in the other world, as I firmly believe that I shall, how pleased I will be to tell her, 'Mother, dear mother! your boy Harry kept his pledge!" His was a happy death; and no doubt he soon joined the mother he so dearly loved. 


\section{Picking the Nets and Trawls, in which we find a Good Haul of Sketches, Incidents and Facts, rel- ative to the Fisherman and his Occupation.}

Getrivo a Fare cnder Difficulties. - Schooner Flisha Crowell Capt. Thompson, of this port, which was out in the gale of January, 1871 , Western Banks, was boarded by a sea on the night of the 9th, which caused ber to part her cable, stove dories, and the men on deck at the time narrowly escaped being wasbed overboard. The weather moderating on the following day they again shaped their course for the Banks, the vessel having been blown of some distance by the gale. With commendable perseverance they set to work patching up the disabled dories, and succeeded in getting three of them in serviceable condition. A few odds and ends of trawl gear, which they fortunately had on board, were made to supply the place of those lost in the gale, and having two or three day's of fine weather they succeeded in taking 15,000 pounds of halibut and 6,000 pounds of codish, arriving home on Saturday, making a very profitable trip. The perseverance of Capt. Thompson in thus finishing up his voyago under such difficulties is certainly worthy of commendation.

A Meritorious Act. - Capt. Ezekiel Call, who was lost in the schooner William Murray, during the severe gale of April 2d, 1871, left a widow and five small children. Soon after his loss she was presented with a house-lot at Riverdale, and her relatives and friends signified their intention of building a honse thereon and making ber a present of it. The money for the lumber was raised by subseription, the cellar stoned and dug by willing hands; then followed the carpentry work, painting, etc., all clone by voluntecrs. The house was ready for occupancy in the spring of 1873 , and the thanks of the widow and the fatherless will descend as a benediction upon the hearts of those who assisted in its erection either by money or labor.

Good PLCck. - Skipper John Hamilton and crew of schooner Robert Emmett, of this port, carried away her foremast on Georges, cluring the gale of March, 1873. They clid not allow this mishap to break up their trip; neither dicl they get another ressel to tow them into port, thereby running up a big bill for the orrners and insurance company to pay. No, indeel; nothing of the sort. But after elear 
ing away the wreck, they very ingeniously rigged up some temporary sails which would answer the purpose of reaching port; then they continued their fishing, arriving home April 11th, with a trip of thirty thousand. Such pluck is well deserving of honorable mention, and the Captain and his men proved themselves masters of the situation.

A Маммотп Cod. - On Tuesday, July 22d, 1873, Miss Fannie Demis, of St. Louis, while on a fishing excursion, off Eastern Point, on board the yacht United States, caught a codfish which weighed one hundred and thirty pounds. Can any of our Gloucester girls beat this? If not, St. Louis has something to hoast of.

Number of Glovcester Frrus Engaged in the Fisming Business. There are forty-three firms engaged in the fishing and fitting-out business in what is termed Gloueester Harbor. Messrs. John Pew \& Son fit the largest number, 20 ; Messrs. Leighton \& Co. come next, having 19 vessels; Messrs. Smith \& Gott follow with 16; Messrs. John F. Wonson \& Co. have 14; James Mansfield \& Sons, 13; while several have $12,11,10$, and so on.

A Good Day's Fishing. - On Friday, June 13th, 1873, Mr Abraham Geering, of East Gloucester, caught, on the "Old Man's Pasture," two halibut whose aggregate weight was 377 pounds. He obtained $\$ 21.34$ for them, which was not a bad day's work. It is very seldom that solarge halibut are caught off this shore.

A Heavy Hadz. - During the month of May, 1873, schooner J. W. Bradley, Captain Griffin, of Rockport, while weighing anchor on Cashe's Bank, found that it came up terribly hard. They hove away for a long time, and on bringing it to the surface, found that they had hauled up an ocean telegraph cable. On coming up out of the water it parted and at once sank. It proved to be the French Atlantic cable, and word was immediately despatched to Boston, and the cable was fished up and spliced in due season.

Begun to Crow Too Soon. - Old Bill P., of East Gloucester, was a quẹer specimen of the old style of fishermen. He was at one time skipper of a small fishing-boat, and had made a poor year's work. Late in the fall, while lying in Salem harbor, he determined to see if he couldn't get a couple barrels of flour on tick, knowing that 
if he could do so he would be pretty well supplied for the winter. Going up the wharf, he espied a provision store, and, stepping in, told a plausible story, and bargained for the flour. The store-keeper, supposing him the owner as well as slipper of the craft, concluded to let him have it on a short credit. Bill was delighted, and while rolling the second barrel down the wharf met one of the crew, and in a self-satisfled tone exclaimed: "See here, Tom, I can get trusted in Salem for two barrels of Alour, while in Capo Ann no one would let me have seren pounds!" It so happened that the trader overheard this, and, tapping Bill on the shoulder, ordered bim to return them forthwith. The old fellow felt extremely chopfallen at this turn of affairs; but there was no help for it, and, amid the laughter of the crowd, returned the flour, muttering to bimself as he went along, "What a fool I was to let the cat out of the bag before we got under-way for Cape Ann!"

A Redarkable Incident of Seafarixg Life. - Many years ago, two brothers, Capt. Nathaniel Smith, of Gloucester, and Capt. Ammi R. Smith, of Ipsirich, made many royages in the European trade. It so happened that while the one was at home the other would be abroad, and they had not seen each other for several years. One morning, on the broad $\Lambda$ tlantic, two ships sighted each other, the one stecring east and the other west, with a strong breeze. The usual preparations were mado for "speaking;" and upon ranging within hailing distances, the sails were thrown back, and there, trumpet in hand, stood the two brothers face to face, each on his own quarter-deck. Affectionate greetings, with the tidings from abroad, and the thrice welcome news from hone were exchanged, and after cordial wishes for each other's prosperity, the vessels filled away on their course. They did not meet again on shore or at sea for some years afterwards.

Dids'T PAY. - Upon the return home of one of our vessels from Georges, the master and owner were extremely loth to settle with the crew immediately after selling the trip, and some of the men were afraid they would not get their money very soon. Among them was an Irishman, who seemed bent on securing money or its equivalent. Finding his efforts failed to bring the "cash" he fell back on the "equivalent," and proposed to take a portion of the schooner's cable in lien of the greenbacks. 
"I should be most happy to accommodate you, Mike," replied the skipper, " but I never 'pay out? my cable when lying in port."

Mike saw the joke, smiled, and walked off, and in a few days a satisfactory settlement was made.

A Singular Circumstance. - During the spring of 1867 , schooner Live Yankee of this port, while on Georges, lost her bowsprit and shroud. A year after, while the crew were busy with their lines, one of them hooked on to something which came up mighty hard. Finally, it was made fast until the tide turned, when it was hauled up and found to be the identical shrond which had been lost twelve months before. There is not the least doubt in regard to its identity, and it is remarkable, that after such a length of time the shroud should be recovered by the same vessel, when there is such a large fleet constantly fishing on the Banks.

Kept His Ninepence. - Twenty-five years ago a fisherman at Rirerdale made a trip to the Grand Banks. He was absent three weeks, and encountered a severe gale, which knocked the vessel down and nearly swamped her. Finally, after great difficulty, he succeeded in reaching port in safety; when, upon settling up, he received as balance due a silver ninepence, after deducting bis storebill. He took it home, and, stringing it on a bit of ribbon, wore it around his neck, making a solemn vow never again to go to winter fishing, so long as he was not obliged to spend that ninepence. He wore it for a long time, and finally hung it up alongside the kitchen clock, where it may be seen to-day, and consequently he has never ventured on another trip.

A Cent Found nn a Pollock's Padnch. - Mr. William Thurs. ton, of this town, while dressing a pollock in the spring of 1868 , found a nickel cent bearing the date 1867 . The question is, how came it there?

"Truth Stranger than Fiction." - There formerly resided here in town a widow woman who, in her younger days, resided in Nova Scotia, where her father kept a lighthouse. One day, during a violent gale, a vessel was driven on shore, and out of the entire crew a young lad alone was saved. Her father took charge of and adopted him as his son; and in due course of time he fell in love 
with the daughter. $\Lambda$ lorer's quarrel occurred, as they oftentimes will during courtships, and he, feeling considerably vexed, went away to sea. The family moved to Gloucester, and tho daughter married one of the fishermen who was lost on Georges. Two years after this event, who should arrive in town but the first lover, whom she had not heard of since he went away. Ho learned she was in town, and after renewing the acquaintance they wero married. Being tired of going to sea, be followed fishing, and last season was lost among those who lost their lires on these treacherous fishinggrounds.

A Plecky Fusmemax. - During the extreme cold and boisterous weather of March, 1872, the ressels on Georges had a rough time of it, and the men were glad to take refuge below, where they could keep comfortable. On board the Frederick Gerring, Jr., there was a plucky fellow named Alexander Anderson, who bad not caught quito bis share, and he was determined to mako up the number. Donning an extra suit, over which he put on his rubber clothes, and tying his sou'wester firmly on his head, he lashed himself securely, and there he stood, with the spray flying over him and freezing as it struck. He, bowever, stuck to his lines and caught fifty-three fish, the number required, and then, being satisfied, left the deek for more comfortable quarters.

Life for One, Deati for the Otuer. - Just before the illfated schooner Messenger left port, Mr. George A. Babcock, one of the crew, was induced to leave the vessel, at the solicitation of Capt. Hopkins, of schooner Caleb Eaton, and go as mate on a herring royage. Capt. Osier afterwards shipped Mr. Thomas W. Gray, former master of sehooner $W \mathrm{~m}$. V. Iutehings, and the vessel left port never more to return. It proved a fortunate ehange for MIr. Babcoek, as he had not the slightest idea of leaving the vessel until a few hours before he consentel to the change. Mr. Gray intended to have shipped in another schooner, but, at the solicitation of Capt. Osier, who was realy to sail and anxious to make his complement of men, concluded to go with him. The chances of life and death are incleed very narrow at times, and every one is more or less exposed thereto. But we never fully realize it until instances like the above occur, and then we are impressed with the fact, that oftentimes a slight incident may result in an entire change of our material prospects, and perhaps, as in this case, remove us from the shores of time into the land of the hereafter. 
Strll in Existence. - The fishing schooner Manchester, which was quite an old vessel when sold from this port thirty years ago, is still in existence, and was sold at auction in Plymouth, May, 1872, for $\$ 662$. She is still good for a fare of fish, notwithstanding her old age. The painting of the late Fitz H. Lane, which was destroyed in the conflagration of the former town-house, had a very life-like sketch of this famous old banker, lying in the harbor cove, washing out a fare of fish. She must be about seventy years old.

A New Fisming Ground. - Country fish-dealer (not posted in geography).

"Here's fresh cod 'n haddock 'n halib-o-a-t."

"What is the price of halibut, Mr. Napes?"

"Twenty cents a pound, ma'am."

"Why! that is a monstrous price; what makes it so dear?"

"It is a very nice article, ma'am, the real Georgias halibut; comes all the way from Georgia, packed in ice ; makes it come high."

Economical housekeeper concluded that she would not invest. 


\section{Dashings of Spray from Wavelets of Maritime Poetry by Home Authors.}

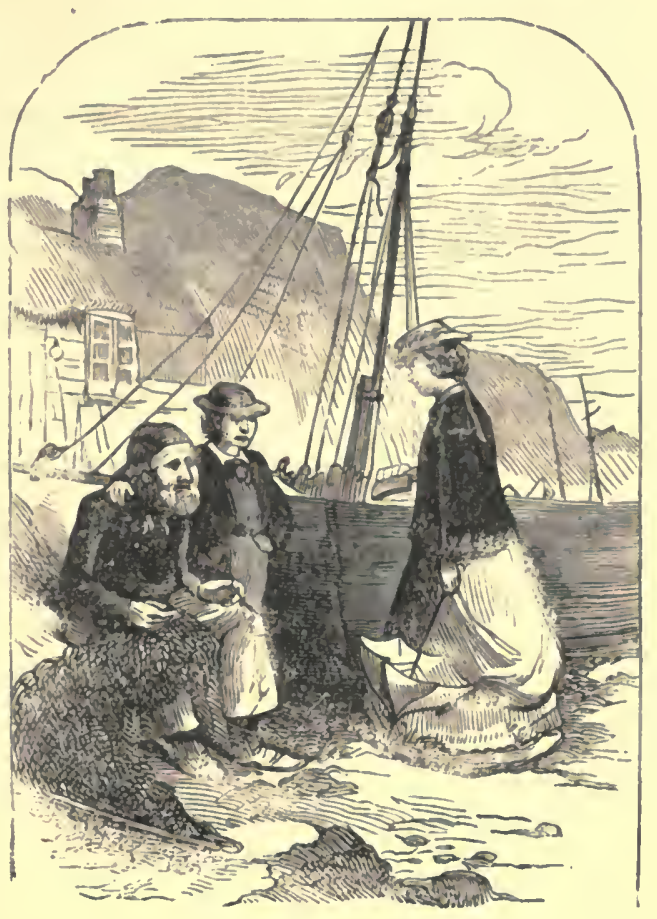

THE SKIPPER-HERMIT.

BY IIRAM RICH.

For thirty sear, eome herrin'-time,

Through many kind o' weather,

The "Wren " an' me have come an' gone, An' held our own together.

Do' know as she is good as new, Do' know as I am, nuther;

But she is truer'n k't' an' kin,

Or any but a mother.

They're at me now to stay ashore, But while we've hand an' tIller, She'll stick to me an' I to her, -

To leave the " Tren" would kill her.
My feet have worn the deck; ye see How watches leare their traces, An' writo on oak an' pine as plain As winters on our faces!

But arter all is said an' done, 'There's somethin' sort o' human $\Delta$ bout a boat that takes at last

The place o' child and woman; An' yet when I have seen some thing Thelr mothers Jet me toss 'cm My boat, the seemed a barnacle 'Longslde a bran.new blossom 
Sometimes to me the breeze off-shore Comes out upon the water,

$\mathrm{AB}_{\mathrm{B}}$ if it left the grave of her-

No wife to me nor danghter.

Lor! If I knowed where green or no The turf is sweet above her,

I'd buy a bit o' ground there, - wide

As a gull's wings wonld cover.

We know the tricks of wind an' tide

That mean an' make disaster,

An' balk 'em, too - the "Wren" an' me -

Off on the Ol' Man's Pastur'.

Day ont an' in the blackfish there

Go wabblin' out an' under,

An' nights we watch the coasters creep

From light to light in yonder.

An' then ag'in we lay an' lay Off Wonson's Cove or Oakses -

None go by our eompass-light,

Nor we by other folkses.

Ashore, the ball-room winders shine

Till weary feet are warnin',

But here an' there's a slck-room light

That winks away till mornin'.
An' Sundays we go nigher in, To hear the bells a-ringin', -

I aint no hand for sermons, Jon,

But singin's allers singin'.

The weathercocks - no two agree -

Like men they arg' an' differ,

Whlle in the cnddy-way I set

An' take my pipe, an' whiff her.

My plpe - ch! p'ison? mighty s-1-0-w;

It makes my dreamin' elcarer.

Thongh what I fill it with now-days

Is growin' dearer 'n' dearer.

I takes my comfort when it comes,

Then no lee-lurch can splll it,

An' if my net is empty, Lor' 1

Why, how can growlin' fill it?

An' so we jog the hours away,

The gulls they coo an' tattle,

Till on the hill the sundown red

Starts up the drowsin' cattle.

The seiners row their jiggers by;

I pull the slide haif over,

An' shet the shore ont, an' the smell

Of sea-weed sweeter'n clover.

Scribner's Monthly.

\section{THE TIDE.}

\section{BY HENRY A. KENDALL.}

The tide is in, anon is out,

Nor lingers at the turning;

And man, as restless as the sea,

Its thriftlessness is learning;

T'wo busy brothers gathering in, And having gathered, spurniug.
The waves bring pearls npon the shore,

Yet on the shore no pearls there be:

For fortune varies $\mathrm{ebb}$ and flow, And with the waves' monotony;

For hopes, like pearls and shells, come in, But with the tide go out to sea. 


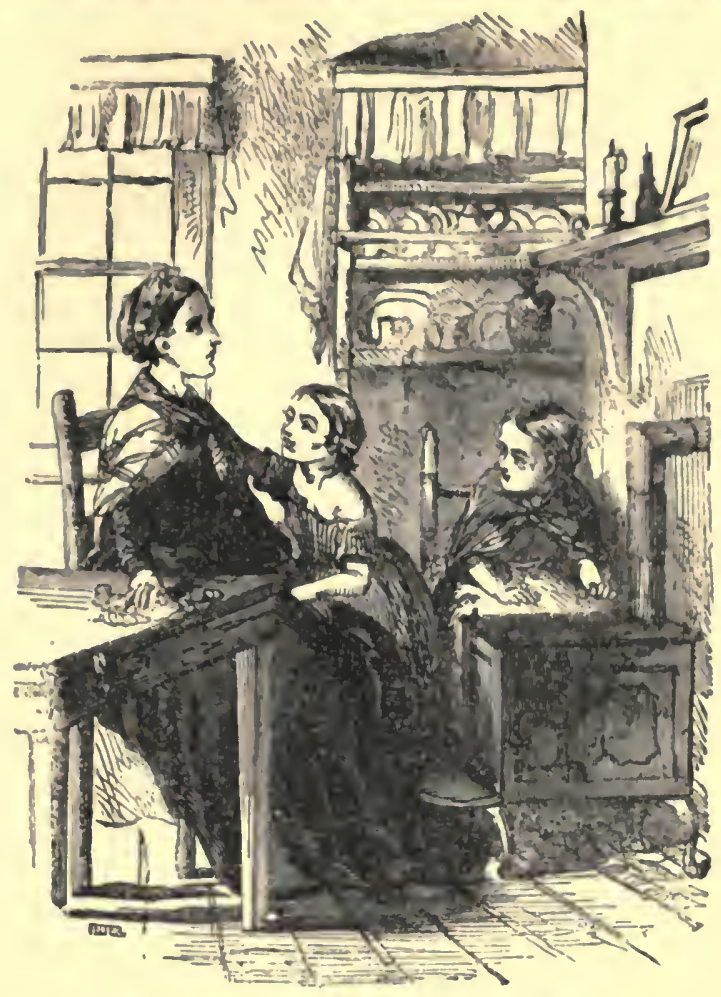

THE BARK COMES BACK NO MORE. BY JAMES DATIS.

Never more, never more,

Cometh back to the shore,

The Ashermen's bark that 80 gaily departed I

And never $n$ word

Of thdings is heard,

To telt of her fate to tho desolato-hearted.

With foll, swelling sall,

Before the fair gale,

The home-port she left with ber flag gally streaming;

And not one brave beart

That in her ded depart,

Of her perilous royage on the ocean was dream. ing.

Far out on the tide

A whlle they did ride,

And the sea's finny treasnres their labor rewarded;

Whlle thoughts of their eheer,

As home they should steer,

$\Delta$ comfort mid toll and privation afforded.
But never again

Shall come back those brave men,

Their forms 'neath the dark waves of ocean are slecping;

And loved ones on shore

Thelr sad fate deplore,

And еуев havo grown weary with watching and wceping.

Tieep no morel weep no morel

Te mourners on shore,

For the lust ones whom fate from your bosoms hath riven;

For though their frail bark

Went down in the dark.

The crew hare nrrired safe in Lore's blesed haven.

And though to the ebore

Shall come back never more

The fishermen's bark that so gally departed.

In that haven above

You will meet them, where Love

Ait sorrow shall chase from the desolate. inearterl. 


\section{ASLEEP ON THE BEACH.}

\section{BY GEORGE H. PROCTER.}

There's a dear little child at play On the beach, with Its pebbly shore;

Bright and joyous the summer's day, And hashed the sound of ocean's roar.

The tiny waves dance up and down, Sparkling and rippling merrily; The child with play hath tired grown, And lain him down quite wearily.

Higher and higher up they creep, Those rippling wavelets tipped with white, Off from the bosom of the deep, Along the sand they take their flight.

In they keep rolling with the tide; The boy sleeps on - 80 free from care;

O'er the waters the light winds glide, And sunbeams kiss his golden hair.

Old grandpa, who can scarcely creep, With palsied limbs - voice feeble, too, Sees from his door the child asleep; Great God! what Is there he can do?

With quivering lips, uplifted hand, He prays, midst sighs and weeping, That the good Lord from off the sand Would save the child there sleeping.

"Descend, O Father, from the skies, And touch with spirit of light My little grandchild's sleeping eyes, Or stay the prond waves' might!"

His prayer is ended; he has done All that he can to save the boy,
And left him in the care of One Mighty to save or to destroy.

Hush ! what does the old man see Skipping along o'er the pebbly ground? Bruno, his dog, who, leaping free, His master joins with a joyous bound.

"Bruno, good dog! there's Charlie dear, Your playmate, lying on the shore; Go quickly, now, and bring him here, Ere rising waters sweep him o'er!"

Showing the dog an old toy gun, Which oft he'd seen in Charlie's hands, He knew at once, and off he run, Bounding across the glistening sands.

The child is reached. Haste, Bruno, haste! There may not need another wave;

The waters rise - Oh, do not waste A moment more if life you'd save !

Brave dog 1 gifted with instincts rare, How gently jou lift that little walf Out from the surf, and with such care Place him above where all is safe!

The mother came with bated brcath; How she had run from grandpa's sidel

She feared her boy had met his death, There on the sand amid the tlde.

But when she saw his opening eyes, And watehed his tiny, heavlng chest, Oh, joy untold! what glad surprise! Ecstatic rapture filled her breast. 


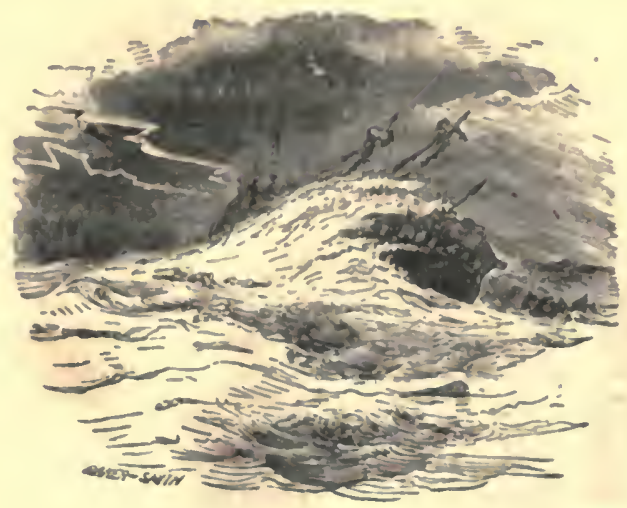

\section{LOST AT SEA.}

BY SARAT O. DULET.

Cost 1

Weary and tempest-tossed,

Lost at sea!

The shlp went down in the foam, And found a watery home,

Whlle the waves resistless roam Wild and free.

Lost 1

Flats of fate were croseed, Lost at sea!

With seaweed and coral dressed, And hand crossed o'er bis breast, In a wakcless, dreamless rest, Sleepeth he.

Lost 1

In ocean's foam and frost, Lost at Bea l

And no tear falls o'er thelr grare, Bnt the restless ocean wave Boams o'er monarch and o'er slave In Its glee.
Lost!

The ones we have loved most, Lost at sea!

For they may not walk the shore, When some long, long royage is o'er, And they, with as no moro Bend the knee.

Lost!

And pallid hands are crossed, Lost at sea !

And maidens' еуев are dim. And mothers' eyes o'erbrim As they sadly think of lim In the sea.

Lost!

They are a mighty host, Lost at Bea I

And the wares say with their moan, I am monarch - all I own -

'Tlis to me they all have gone, Gone to me. 


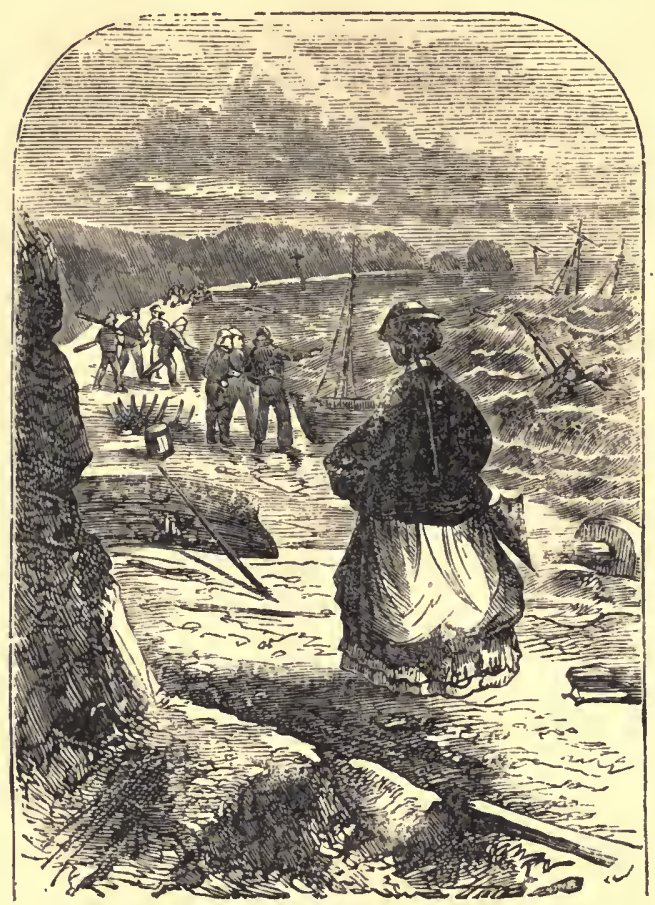

\section{AFTER THE STORM.}

\section{BT HENRT C. L. HASKELL.}

I would I could paint the pieture I have only to shut my eyes

And a long white reach of sandy beach Will straight before me rise.

\section{And a mass of dusky blllows}

White-maned and tumbling in

With a erash and roar to the sandy shore,

And a wild and ceaseless din.

Behind in the west, a rampart

$\because f$ elouds that are dun and wild,

And the sun just dips to thelr erimson tips

Where the darkest mass is piled.

There where the waves seem fiercest,

Ir their maddened rush and roar -

With her starboard slde to the tossing tide

Lies a fated bark, ashore.

Her tall risusts bend as the billows, Rising in stormy might,
Are a moment seen of a dusky green. Erc falling broken and white.

I ean see her mainmast totter, Then plunge in the seething tide;

While toward the strand of damp wnlte sand The shattered fragments glide.

There goes the foremast orer, Whiter the great waves curl; And over her pour with thelr sullen roar, And a maduer rush and whirl.

We turn from the white beach homeward, But pause to glanee onee more;

The moonbeams shine in a silver line O'er the waves to the sandy shore.

For the purple of eve has gathered And spread from the eastern skies;

And the billows moan where shattered and lone

A dreary wreck sho lles. 


\section{THAT SUMMER DAY AT NORMAN'S WOE.}

IT OEORGE II. PROCTER.

Mem'ry, lend your maglo powers,

Ietrace the pletures one by one;

IRoll beck the years, reenll the hours -

That summer day In 'any-ono.

Turn bnck the pagea In Ilfe's book, $\mathrm{Ob}$, falthful mem'ry, fond and true;

Once more reveal the cozy nook

At Norman'. Woo- the scene redow.

Old ocean In Its calmest mood

The boats swaged gently by the tlde;

While o'er across, the Ilght-honso stood,

Which winter'a storms had long defled.

That day so fragrant with its joy,

Her whom I lored - that pleasant stroll;
Puro happlneas without alloy -

IIeart answered beart and woul met woul.

She gave the promlso - untold blies!

Through all our Ures our love whould Low;

Wo sealed tho promles with a kJan.

That summer day at Norman's Woe.

Wo'vo walked together twenty years -

On-times tho path has not been smooth,

Ilut e'en theso varted hopes and fesrs

IIare served as teate our love to prove.

I ne'er regret her saylng yes,

And glving mo ber heart 80 true;

Lifu's cup is full, for mine's the blfse

of belng loved, and loving too.

\section{SKIPPER JACK.}

BY OLD LOCALITT.

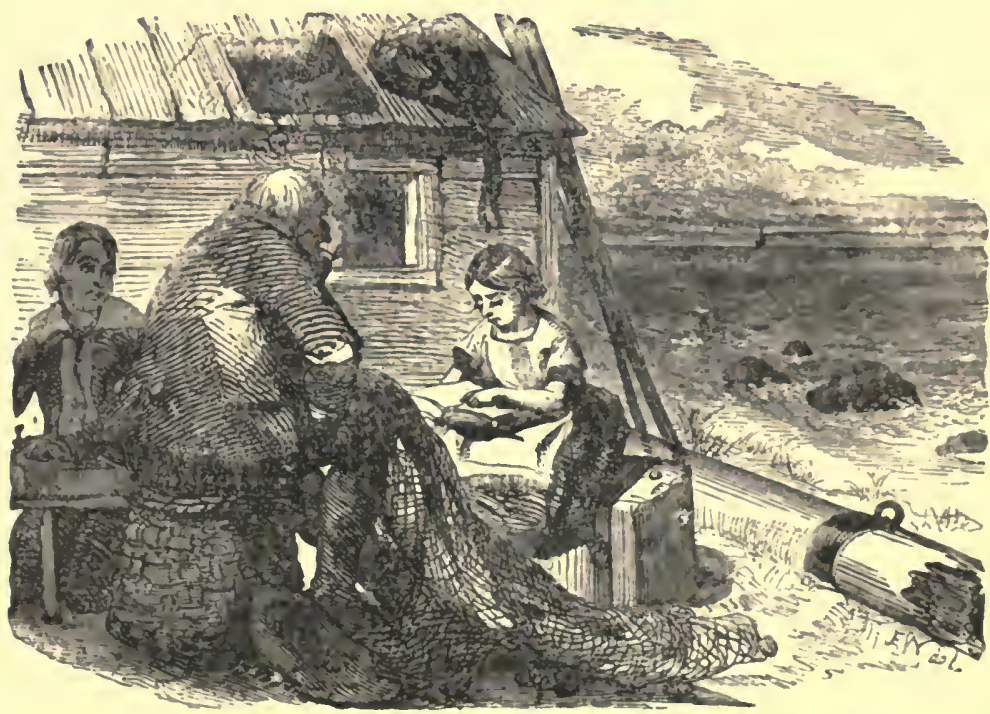

Wlth bair whito as the soa-gull's plumo

All bleached on the stormy sea,

With features bland, and large of heart,

1 kind old man was be.
The battling storms of elghty jears On llfe's long ocean roll,

II ad left no spray In hls eagle eye, For ice on bls noble soul. 
His smile came out with a sunny gleam,

As it came in the days of yore;

And his voice had a soothing charm like the waves

When they sing on a shelving shore.

The young folks gathered at eventide, With a bright, expectant cye,

For a ballad tune of the olden time, Or a tale of the daye gone by.

He sung of the fight on Bunker's Height, And how the red-coats ran;

How Lawrence brought his noble ship In sight of old Cape Ann.

He told that far, far back in the past, Full sixty years and more, The old ship "Howard" stranded, lay A wreck on our rocky shore.
He sung of the deeds of Captain Kidd, How the pirate loved to rove;

Of the shining gold that he had buried deep In the dingle at Grapevine Cove.

He told of his childish sports, and how Full seventy summers back,

The glow on his eheeks was the bloom of health, And the curle on his brow were black.

And he fondly smiled on the gentle Sue Who sat near his aged knee;

And pressed his lip to her shining brow, For a kind old man was he.

Then drop a tear for Bkipper Jack, The best of the brothers seven; We wonld not call his spirit back From its anchor-hold in Heaven.

\section{JERRY AND ME.}

\section{BY HIRAM RICH.}

No matter how the chances are,

Nor when the winds may blow, My Jerry there has left the sea With all its luck an' woe;

For who would try the sea at all, Must try it, luck or no.

They told him - Lor', men take no care How words they speak may fall -

They told him, blunt, he was too old, Too slow at oar and trawl;

An' this is how he left the sea, An' luck an' woe an' all.

Take any man on sea or land, Ont of his beaten way,

If he is young 'twill do, but then, If he is grieved or gray,

A month will be a year to him, Be all to him you may.

He sits by me, but most he walks The dooryard for a deck, An' scans the boat a-going out, Till she becomes a speck.

Then turns away, his face as wet As if she were a wreck.
The men who haul the net an' line Are never rich; an' you

My Johnny here - a grown-up man Is man an' baby too.

$A n^{\prime}$ we have naught for rainy days, $\Delta n^{\prime}$ rainy days are due.

My Jerry, diffident, abroad As restless as a brook, An' when be left the boat an' all, Home had an cmpty look;

But I will win him by an' by To like the window nook.

I cannot bring him back again The days when we were wed;

But he shall never know - my man The lack o' love or bread,

While I can cast a stitch, or fill A needleful of thread.

God pity me, I'd most forgot How many yet there be, Whose good men, full as dear as mine, Are somewhere on the sea;

Who hear the breakin' bar, an' think Of Jerry home an' me. 


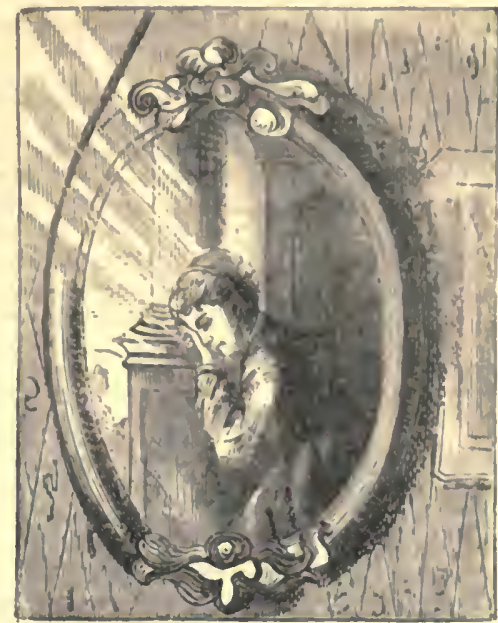

\section{THE FISHER'S WIDOW.}

\section{BY OEOROE H. PROCTER.}

Fair was that morning in winter,

When he klssed her good-by. Falr was the breeze

Which fllled the salls of his schooner,

As gayly she sped out of the harbor for Georges.

Fondly she gazed ance him,

Watching the white foam which feathered the track

Of the "Margery" - her name, and that of the trim

Little craft he commanded.

Her prayers followed him,

And each night as her head pressed the plllow, Her God was entreated to caro for all

On the watery depths; then one

Eardest plea for Roger, - whose heart was hers, -

Would fall sweetly asleep, with

Dreams full of bright plctures and fancles.

Three weeks passed away,

Bringing around the time for his return;

How anxlous now the hours! For those com ing in

From the treacherous Banks, brought fearful udings

of a sudden galo 1 Terrible the tales

of drifung vessels, of collislons and founderings,

Of hair-breadth escapes, broken spars,

And parted cables.
One after another, the fleet slowly rounded the Polnt,

For the wind had spent Itself, and was gentlo now;

But nearly all had torn salls, damaged spars or halls.

As thelr namea were repeated, many a heary heart

In Gloncester town grew light; wires and chil. dren

Were happy as they greeted hosbands and fathers

Whom they feared would nevermore return.

"Where's the 'Margery'? Have you eeen her?

Tell me truel Hape you not spoken the 'Margery,'

Or seen her since the gale?"

These were the queries whlch the young wife made.

One sldpper sald, "The 'Margery'

Lay right 'Jongside hls ressel - the ' Culon,

Two days afore the blow, and hsd shined berthe

Early in the moru'n' in hopes to finlsh their catch,

Then bomeward go." Another sald, "that a ressel,

Which he wok to be ber, had started for home 
The very mornin' of the gale;" while yet another

Thought he "saw her adrift, drivin" down to lu'ard;

Where the heft of the fleet were layin'."

The young wife hoped against hope,

Thinking that the "Margery" had been blown off,

And gone into some distant port

Where tidings were long in coming;

Or that her husband and his men

Had been taken off by some vessel bound afar, And they would come back again.

But the "Margery " never more returned to portl
She sank 'neath the waters, in that fearful storm:

Three other veasels went with her, and forty souls

Winged their way upward, -

With them, the skipper of the "Margery."

The fisher's widow has taken up ber cross, And carries it with a firm hope Of again meeting her loved one

In that land beyond, where those who sail The sez of life are sure to mcet at last.

This hope brings comfort,

And to-day, with heetic flush and feeble breath, She's drawing near her home, having a hold on God

Strong as the everlasting hills.

\section{LOOKED FOR.}

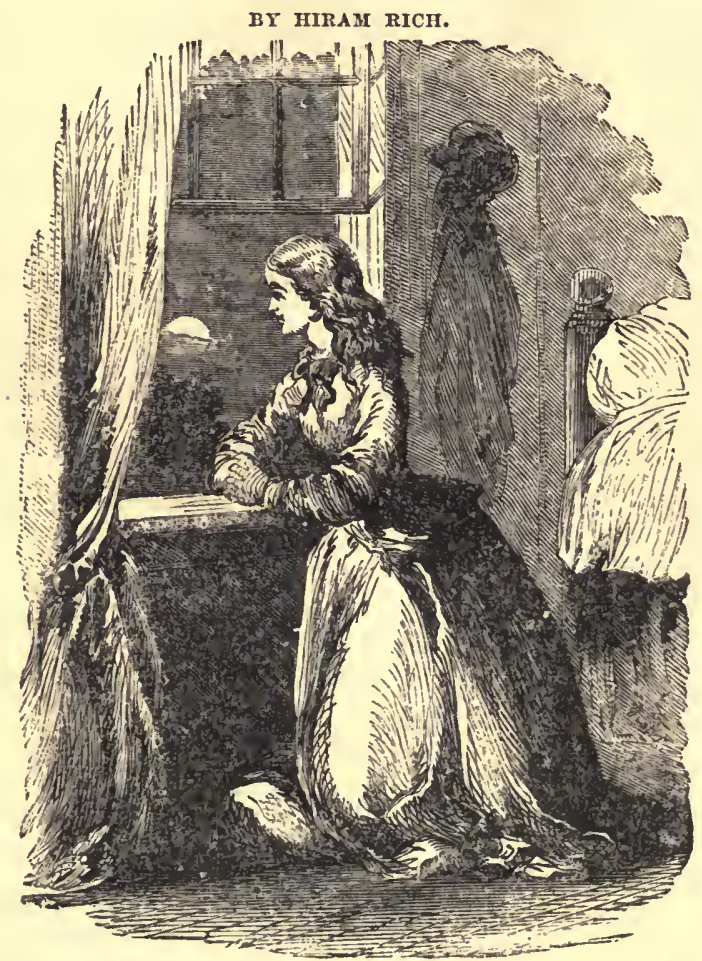

"All the applo blooms are open and the bees are in a flurry

While I walk the headland orchard, by the sail-beclouded sea, -

The single sail I look for's a long time a-com. ing,

And a day is longer now than a summer used to be.
"Every nfght I malse a beacon of my little chamber window;

Often at the door I listen, with my hand upon the key;

The slngle sail I look for's a long time a-com. Ing;

But the sudden footstep in it hath no echo of the sea. 
"All my baby-sewing Inlabed, I am knltilng, only knltting,

For he loven to find me ldlo-llke when com. Ing home from sea;

The slaglo anll I look for'a n long timo accom. Ing;

But a dny witbout my peedlo is a weary ono to mo."
All the applo blooma are falten and the Idlo bees are dreaming,

And deserted is the orchard by tho sall-for. asken sea;

Tho only shlp sbe looked for is anchored in the barbor,

And a sallor oles at supper with s happy rls-avis.

The Independent.

\section{SKIPPER CHARLEY OF GLOUCESTER TOWN.}

BY OEOROE H. PROCTER.

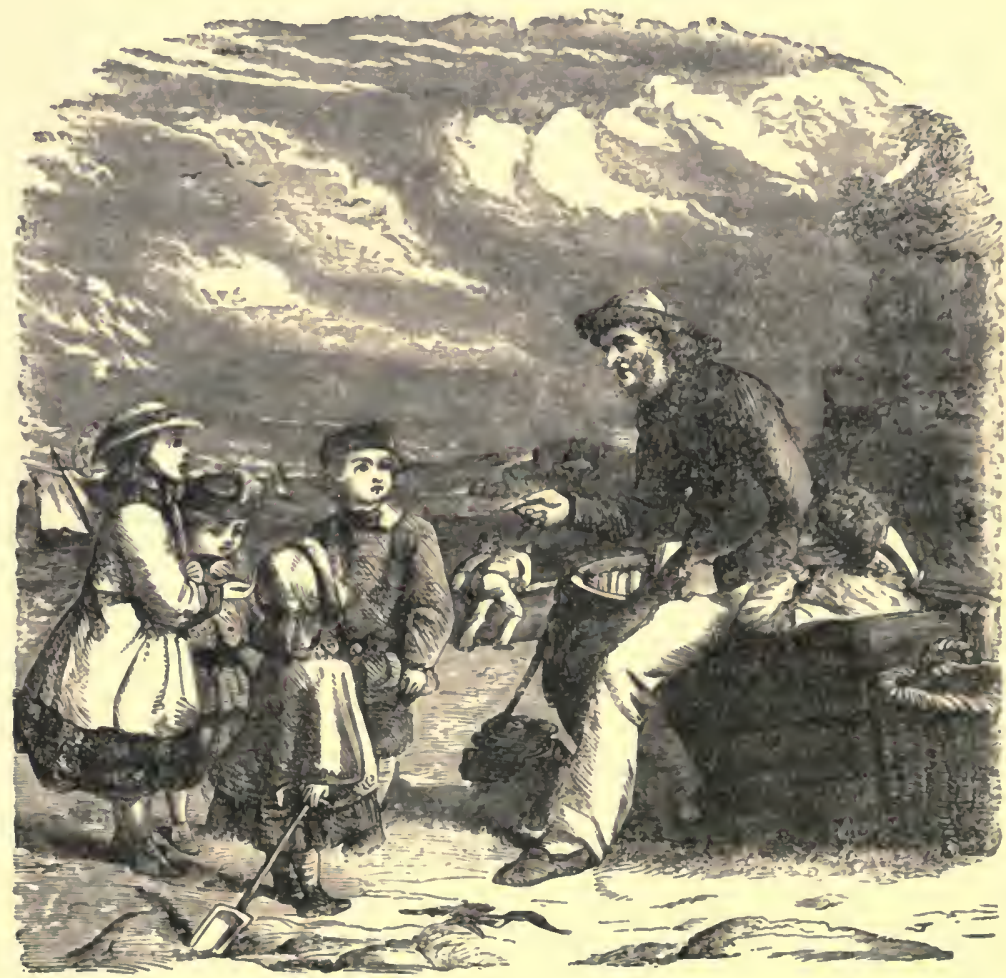

Don't you know skipper Charleg, of Glouces. ter town,

$\triangle$ jolly old fellow of upwards fourscore,

Whose sung llttle cot, weather-beaten and bromn,

Stands at Eastem Polath close down by the shore?
Skipper Charlle's first trip was in clghteen two,

In the jigger" "Iantha," which for those times Was a crack litllo cran; and he will tell you, Ho was ten years old when be first pulled tho Hnes. 
For sixty odd years, throngh all kinds of weather,

He sailed the salt water in sunshine and storm,

Sharing the comforts and dangers together

Wlth shipmates many - but now they're all gone.

'Tis thrilling, I tell you, to hear him repeat

The narrow escapes he has had in his day;

And many's the erening I've taken my seat

In his chimney-corner so cozy and gay.

"Wa'al, 'bont as nigh as I can remember,"

(The skipper most always commences this way,)

"s 'Twas elghteen forty-two, the first of November,

Comin' from mackrellin' in Penobscot Bay.

"Thatcher's Light we saw just 'afore the day broke, -

Didn't the wind howl? what a wild-lookin' sky I-

When out from the for'castle curled up a smoke,

An' then follored a blaze most half-mast high!

" We did all we could to smother the fire.

'Twasn't any use tryin' to stop its flerce glow;

It kep' on a blazin' hlgher an' higher;

'Twas soon quite sartin tho old Betsey must go.

"We jumped in the boat as soon as we could; I shiver to think of that mornin's crulse;

Obleeged to take passage in just what we stood,

Life was dear to as then - faultofindin's no use.
"We contrived to keep the old boat alive, 'Twas 'nip and tuck' in that heary sea; But the good Lord helpeth those who strive, An' he sent a vessel - that's my idee.

"For nineteen seasons, one arter the other, I went to Georges - an' that's no boys' play!

'Twas there the sea washed off deck my joung brother,

An' afore my own eyes he drifted away.

"We couldn't save him, I knew that full well; But I heard him shout, and my name loudly call;

Then I saw his dear face as he rose and fell

On a white-capped billow - and that was all

" Irany a night arter, I'vo waked up from sleep At hearin' that call, and my dead brother's form

Has appeared, as if comin' up from the deep; I saw him so plainly - and then he was gone.

"I went one season more, that of 'sixty-two;

Time of the big blow-you remember it well:

What destruction and sorrow then did accrue From that storm on Georges, words fall me to tell1

"Such a terrible night 1 Oh l didn't it blow ! An' over a hundred vessels were there:

When one parted her cable, away she'd go

Right into another, and down went the pair.

"We rode it ont, safely, but how, I can't tell; Fifteen of the fleet ne'er again h'isted sail;

An' a hundred and thirty-elght lives went to swell

The losses on Georges, in that dreadful gale." 


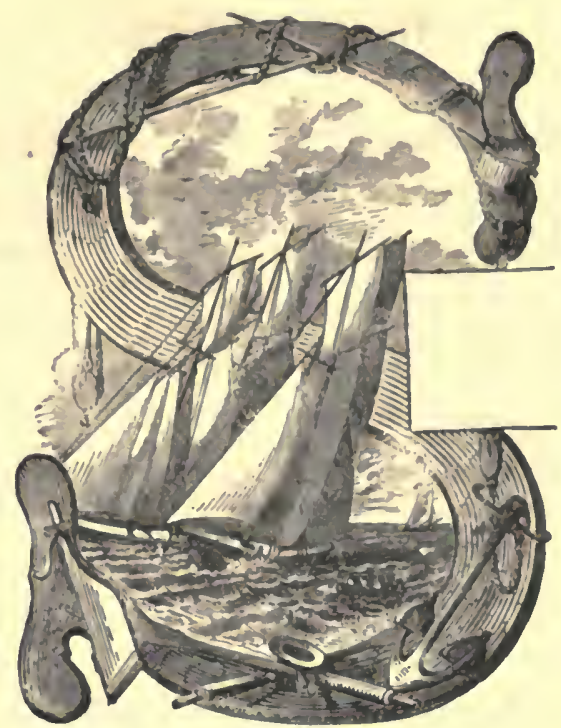

YACHTING.

BT HENRT A. RENDALL.

FYII, snowy inlle, untll our ralls

Careening klas the wea;

White creats of foam abandon home To bear us company 1

And, brave topmast, defy the blast, Clear whlstle in the wind;

Thege bright green waves were never graves, Till hope was len behind.

Nor bopeful decks can turn to wrecks While water washes keel -

"Bo blnd the sheets to weather-cleats," Loud sings the pilot at the wheel.
These clonds, storm-gray, will burn nway, The wind go down with the san;

And Dlan bright, with her sllver light, Will gild our salls ae we onward ran.

Already in lulls we hear the gulls, And see the petrele flitting by;

And He whose might notes swallows' flight, Will give us at length a tranquil sky,

And wind as falr as stirred the alr, With waves that dance, as when Columbus len the Indian 1sles, And steered his ahallop back to BpainI 


\section{THE TWO TRYSTS.}

BY In In

A billside stretching seaward, ripples of shinIng blue,

And tide-waifed strand of rifted sand lnelined between the two.

On ebb of the waves, slow rocking, impatient at long delay,

The whlte-winged boat, with pennon afloat, tosses her shadow in play.

A cot with its blossoming tree; lover and fairhaired maid,

Standing alone by the threshold stone, holding their tryst in the shade.

Hope and joy, with a twofold power,

Bind heart to heart in the twilight hour.
A hllislde stretching seaward, and tide-waifed sanded shore,

But white-winged boat with pennon afloat plays with its shadow no more.

Feet grown weary with waiting, eyes watch. ing over the sea,

And life's sweet dream of golden and sheen rest 'neath the blossoming tree.

A dlrge from the moaning waves, tears from the twilight dew,

And hands of love, beyond and above, are pledging their tryst nnew.

Hope and joy, no longer at strife, Bind soul to soul in that better life.

\section{THE LOSS OF THE SCH. JAMES S. AYER.}

\section{BY HENRY A. KENDALL.}

I sce her mainsail in the sun

Gleam bright as any swailow's wing,

As ready to fily when ali is done-

I hear the hardy fishers sing;

Ont round the Point, and past the light

That guards the ramparts of the Bay;

Still sailing on through all the nlght,

And on and on from day to day;

But never to return, $O$ shlp 1

Thou bearcst a dead crew,

With faces white and drowning lip,

And eyes upstaring to the blue;
And costly freight of mothers' tears, But, more than all, those dead men's lives, With all the promise of long years, And prayers of wldowed wires.

Yet know we not; white sails she spread, Was spoken once, and evermore

Their children listened for the tread Of those who kissed them at the door.

And bade them watch their coming back, And kissed them sweetly, one by one, Then sailed away to death and wrack, Thy will, O God, thy waves have done! 


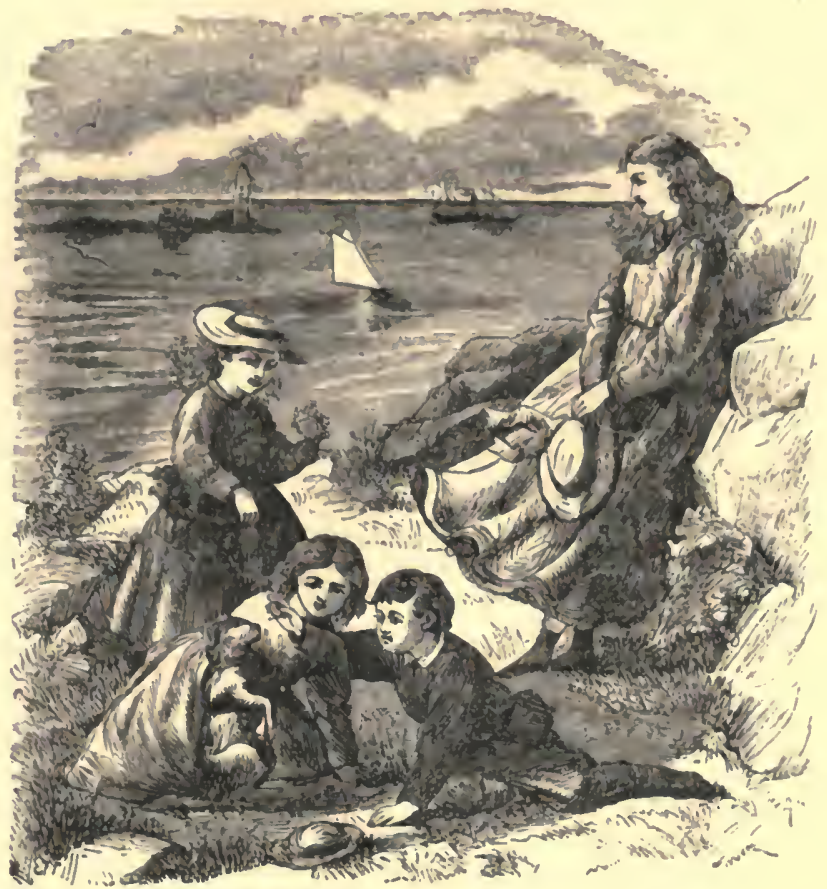

\section{A WAIF.}

\section{BT II C. L. MASKELL.}

The autumn day

Iflch Inlts regal beauty lay

Orer headland and beseh and sea.

And the voleo of the waves Bang dreamlly

$\Lambda$ sweet, low talo to tho listening ear;

$\Delta$ tale, as if nerer a breath of fear,

Or shadow of eorrow, conld cloud tho bluc, Or darken tho sunlight glinting through

Tho mellow air. It was fair, I ween.

That antumn sunlight, that harbor ecene, As over tho waves, that golden day, A trim bark salled on lis royage away.

\section{Glonecster town}

Lles whero tho winter sunbeams down Onits roofs and spires are sbining bright, On the tall masts showing slim and bare,
On Stago Ilend Battery, and whero

Gleams the tower of Ten Pound Island Ugbt: But never again to Gloucester town, Around the Point and up to the town Will the good bark glide, that salled away In tho dreamy hush of that autumn day. Thero'ro those who'll waitand watch and weep, And gazo afar o'er tho heaving decp,

And wish for the loved to come once more For the bark to sail for Cape Ann's shore.

Ah I none may know In the Ben-girt town IIow or when that staunch bark went down For those who within her salled tho maln Never will come to port again.

Father of goudnees and mercy be

Witb those who mourn for the lost at sea I 


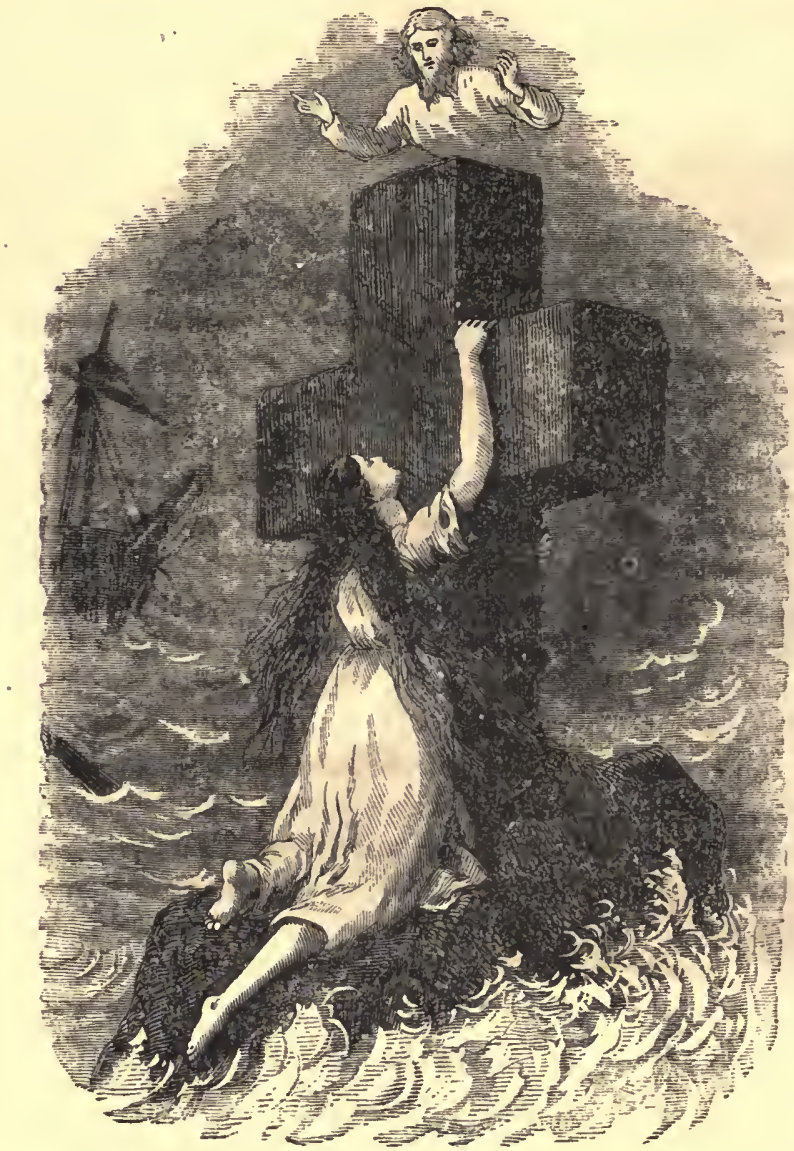

NOT LOST, BUT CONE BEFORE.

BY MRS. MARY A. SHELTON.

Respectfully-inscribed to the friends of the lost fishermen.

Not lost, ah I nu; only gone on before, They are anchored safe on the shining shore; The souls ye loved icft the vessel's deck, As ocean folded the sinking wreek, And white-robed angels led the way To the fadeless realms of eternal day.

In lonely caves, 'neath the surging deep, The forms ye loved lie in dreamless sleep, The ocean waves chanting as they flow, A mournful requicm soft and low, Seeming to say, "O fisbcrs, for thee Do we chant this solemn melody."
There's a sable cloud o'cr the fisher's home, $\Delta$ longing for those that can never come; Watching and waiting, alas, how vain, For steps they never will hear again! O God! thou alone canst give relief To these stricken souls in their bitter grief.

Fold them, $O$ God, In thine arms of love; Polnt them to that beautiful world abore, Where 'mid a brlght-robed angel band, Thelr loved, not lost, in glory stand; May they mourn no more for the souls at rest For their Father called, and he knew best. 


\title{
WAITING, ANXIOUS WAITINGI
}

\author{
BY R. C. CALDER.
}

Thero is walting, anxlous walting, for tho Deberman's retarning,

And the angry winds aro tlowing, as tho blllowe loudly roar;

There's a beacon In the window, and a cheerful fro Is buraing,

To gulde the storm-tossed mariner in safety to the shoro.

There is walting, on the deck, where the Ishermen aro standing,

And fervent prayers are offered that the storm may soon be o'er;

All the axls aro torn to rlbands, and the cables now are stranding, -

o God! havo mercy on them I they are driniog on the shoro I
There is walting, anzlous walting, for the $t$. dings of the miselag -

And tearful eyes are looking In sadneas to the shore;

And the mother's heart fo aching, as the eblld abe's fondly klsalog,

Whlepers soniy from ite cradle, "Wul papa como no more?"

Thero is waiting, anxlous walting, and the days and wecks aro Ifying,

Yet no comlug of tho miseing cver glads the watcher's ejes;

And the wave for aye are surging, with a wild and mournful slghing,

Whero in dreamless rest, tho fisher with bls shattered ressel les.

\section{AFTER THE CALE OF 1862.}

BY 0. B.

[The following lines were suggested upon bearing tho wives and relatires of those on board the missing vessels of the Georges fleet making Inquirics of a returned Georgesman.]

"Scaman! where art thou from? Art thou from Georges' tide?

And will hose others come?

Do they in safety ride?

"Didst thou my husband see? And was my brother there?

And my son, wlll he come back to me, With his locks of shining halr?

" At home my children weep; Now tell mc, seaman true, $\mathrm{Oh}$, doth their father sleep Beneath the waters blue?"

"Woman, the nlght was dark, The sea too much to brave;

I fear thy husband's bark Hath sunk bencath the ware.

"And your brother, too, was there, Tossed by the treacheruus main; And he with the shining halr Shall ne'er return again.
"Chlldren, your Pather sleeps, Benenth the waters blue;

But God his promlse kecps. IIo will take care of you.

"Of chlldren onee he sald,

'Suffer them to como to me;'

Is not the raven fed

By his boundless charity?

"I'll tell thce moro to-morrow;

Tho tcars come to my eycs.

Go home and calm your sorrow

By prayers to Ilim on high.

" Ilath not the Baplour told thee

To come in thy distress?

In his arms be will enfold ge,

The "widow and fatheriess.

"And all with sorrow laden, May come to him in prayer,

And jose that are unfading

With them from bearen he'll share," 


\section{COD BLESS THE FISHERMEN.}

\section{BT CELIS.}

God bless the fishermen! God be their guide, And pilot them safely o'er the dark rolling tide; Calm the fierce winds and stlll the deep sea;

Watch them and guard them where'er they may be;

For their life is at best a perilous one

And the little they gain, how dearly 'tls won!

Around them wild dashes the white seething foam;

Yet they cheerfully toil for the dear ones at home.

Oh, scorn not the fishermen, greet them with love,

And ask for their welfare a boon from above.

Their lot is a hard one; their home's on the wape,

And oft 'neath the sea they find a grave.

Love them sincerely, be to them kind;

Their friendship's the truest you ever can find. $\mathrm{Oh}$, once the sad heart, now a desolate fane,

Was wiritten all over with a fisherman's name.
You ask why I love them; - I'll tell you why, Although it shall wring from me many a sigh.

Alas, it gives me a keen, bitter pain

To speak of the lost one I'll ne'er meet again;

Oh! the loved one, the lost one, where is he now?

The cold sea is laving his manly brow;

For he sleeps in old ocean, his grave's in the tide;

He went to his death in the lost "Neptune's Bride."

And since that sad night, my heart's fervent prayer

Goes up for the fishermen everywhere.

God save the fishermen I may he be their guide,

And pilot them safely o'er the dark rolling tide.

Oh ! calm the fierce winds, and still the deep sea;

Watch them and guard them, where'er they may be.

\section{IN SICHT OF HOME.}

\section{BT MRS. SUSIE MERCHANT.}

Roll on, O ocean! tell the same sad story

Of fond hearts crushed by thy resistless flow;

Of all the hopes deep buried 'neath thy waters

We ne'er in time, can ever, ever know.

Tell of the night, when dark and dreary, And tempests raged upon the waters deep;

Tell to the loved one sadly waiting -

And having lost all hope, can only weep.
Tell, when the tempest at its highest,

"With no eyo to pity and no arm to save," The one her heart has ever held as dearest,

Found 'neath thy troubled waves his ocean grave.

Tell how the last prayer that he offered

Was, "Father, keep my wife and little one; Ob, may she know how tenderly I loved her And that I died when just in sight of home!" 


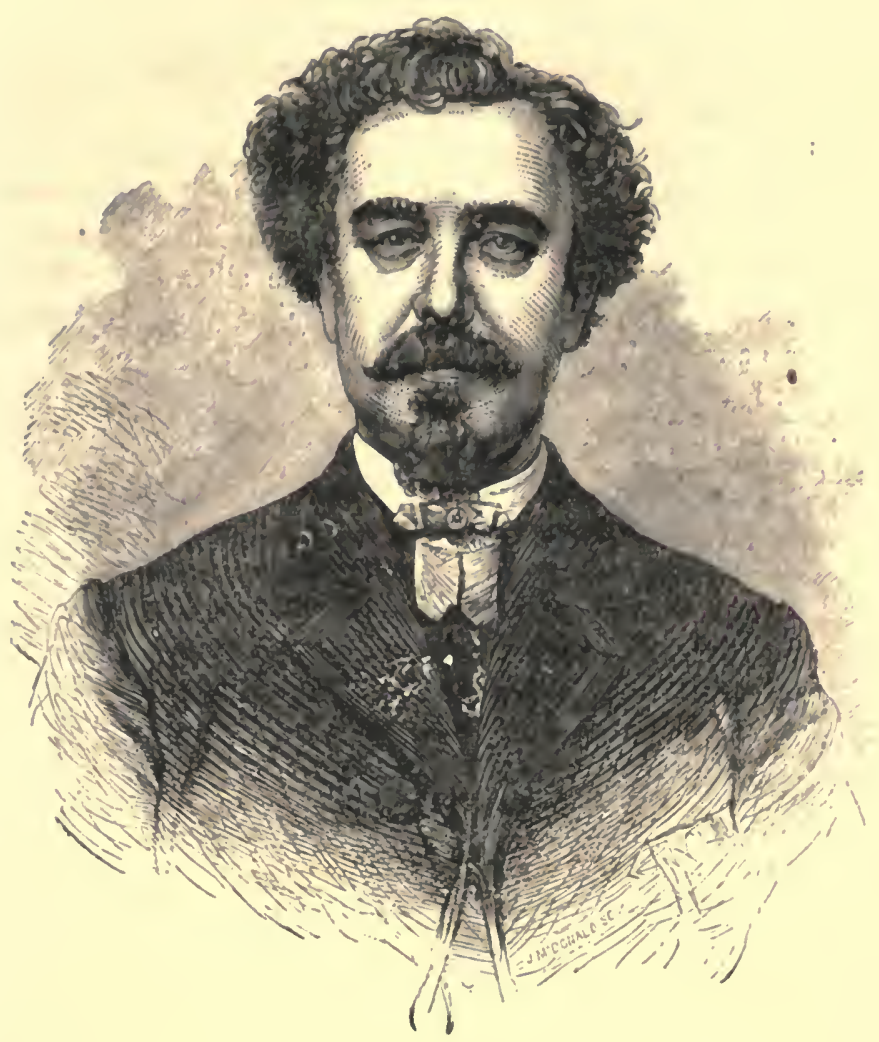

\section{A Musical Fisherman. - His First Violin, - Early} Struggles. - His Cruise in the "Rival." - Shipwrecked Yankee Fishermen Giving Concerts in the Provinces.

Professor Joun Jay Watson, now President of the National American University of Music, and other Liberal Arts, in New York City, began life as a fisher-lad, and followed the business several years. He commenced fishing at the early age of eight, and at fourteen his brother Robert offered him a full share if he would go with 
him in the schooner Garland. From his early youth he was passionately fond of music, and was never so happy as when listening to the songs which flowed so sweetly from the lips of his mother, who possessed a voice of great purity. His father was also a good singer; and it may be safely asserted that John inherited his rare musical talents from both parents. Another great pleasure was afforded the lad, in listening to the impromptu playing upon the violin by the fishermen. He would stand spell-bound as it were, completely oblivious to all surroundings; his soul revelling in the enjoyments which the merry strains afforded, and his face all aglow with enthusiastic admiration; his feet and hands keeping time, and his body swinging to and fro in the ecstasy of boyish delight.

On boárd the Garland was a very kind-hearted fisherman, Mr. Joseph Wonson, of East Gloucester. He possessed a violin - fiddle, the fisherman called it; and during the evening hours, after the day's catch were dressed and taken care of, he would play a few simple airs. This was heaven itself to the music-loving John, and that was a happy moment, indeed, when Mr. Wonson told him that he might try and see if he could play. How the lad labored, and, with trifling assistance from Mr. Wonson, he soon learned the simple tune of "Auld Lang Syne;" then followed, "Haste thee Winter, Haste Away." Mr. Watson informs us that among the many successes of his musical career, none ever afforded him so much real, unalloyed pleasure, as the fact that he could really play these tunes.

During the trip Joln improved every opportunity for playing ; and the owner of the fiddle agreed to sell it to him, bow and all, for one dollar. The trip turned out poorly, and John, whose finances were low, could not purchase the much-coveted instrument. When returning to port he left the Garland, and shipped in the Helen, which was owned and commanded by his father. The first day out they came across a large school of haddock, and John hauled them in so fast and worked so perseveringly as to win frequent encomiums from his father, who predicted that the boy would make one of the smartest skippers in the fleet. The veteran, however, was not aware of the cause of John's applying himself so energetically. The boy did, however, for there was constantly appearing before his eyes that violin. The sales of his fish would give him money to purchase it. They got a good trip, and his father very willingly advanced his son some money on account. With nimble feet he made his way to East Gloucester, found Mr. Wonson, and came back with the violin under his arm. 
Then commenced the trials and vexations which always accompany the struggles of genius. An old fidller, named John Chandler, gave him lessons, and every spare moment was devoted to practice. He got consent to stay nt home one trip, and his time was mostly spent sawing away with his bow in his father's barn; and on Wednesday and Saturday afternoons, followed by a score or more of adiniring companions, ho would stroll up into "Judy Millet's parlor," or in "Strey's Pines," where he would give free concerts. When he went on his next fishing-trip, it was with the express understanding that he should carry his violin and play when there was no work to do. Many a fisherman who reads this will well remember how nicely Watson could play those popular airs, "Roll on, Silver MIoon," "Dearest May," and "O Susaunah." Then those charming little waltzes which followed. We've heard them all, time and again, and can very readily recall the peculiar flourish with which Joln, even in those days, handled his bow.

In 1850, his health, which had been impaired by a long fit of sickness, rendered it necessary for him to talic a fishing cruise. He shipped with Captain David Brown, and, while lying in N. F. Harbor, Mt. Desert, during a storm, availed himself of a few hours of fair weather to give the fishermen, who were lying there together, a little music. He had, during the previous winter, taken lessons of Prof. Fenollossa, at Salem, and made the most rapid progress. He now played some of the most difficult airs, and gare his listeners a touch of all linds, from the simple to the more artistic productions.

After he had concluded his playing, a boat put off from one of the vessels, and there came on board Capt. O. R. Gross, master and orner of schooner Rival, of Truro. He introduced himself to Capt. Brown, and inquired who it was who had shown such proficiency in playing on the violin.

"There's the young man," replied Capt. B.

We will give the account of this first interview in Capt. Gross's orn language: -

"I lookel toward the companion-way, and there sat a young man, as pale as a ghost, his form emaciated to a painful degree, the results, as I afterwards learned, of his sickness. On his head was an old tarpaulin hat, and bis whole malie-up was rather unattractive. As soon as I shook his hand and heard him talk about music, his appearance was forgotten. All that I knew, saw or cared for was the man, and not his apparel. We talked of music, and Watson charmed me with his enthusiasm. At my request, he took up his 
violin and repeated some of the airs which had before impressed me, and $I$ knew at once that he was a born musician. I made him promise that be would come on board my vessel, and stay there until the storm was over. It lasted several days, and proved a season of exquisite enjoyment to us both. I also made him promise to go with me in the Rival, the next year, as first hand."

The season of 1851 found Watson on board the Rival. They made successful trips off shore, and in September went to the Bay of St. Lawrence. They had a musical crew throughout, consisting of Capt. O. R. Gross, violinist, tamborinist, violincellist, flutist, singist and pianist; John Jay Watson, violinist, guitarist, pianist, singist, etc.; Hiram S. Buffington, violincellist and dancist; Adrian Lufkin, violinist and singist; George Urquhart, violinist; the black cook also manifested a musical taste, but as some one greased his fiddle-bow, the first night out, it was never known what his special acquirements were. He took the insult so much to heart that he left the vessel the first'opportunity which presented itself.

All went well with the Rival, and her merry-hearted crew. They had obtained almost a fare of mackerel, when the fearful gale of Oct. 3d came on, and, after a very narrow escape from foundering, in which all hands would have found a watery grave, she was driven ashore at Cascumpec, Prince Edward Island, where they landed, taking the precaution to save their instruments. Here they were received by Patrick Cahill, a kind-hearted farmer, and that evening they gave a musical entertainment at his residence, the like of which had never before occurred in that locality. All but Watson and Gross took passage home in other vessels. These two, however, had conceived the idea of bettering their financial condition by a concert tour. Capt. Gross was engaged to play the organ one Sunday in one of the little towns, and Watson pushed on to Charlottetown, where he scattered the programmes and put up posters, announcing that Professors Gross and Watson, the celebrated violinists and vocalists, would give one of their unique entertainments, etc. When Gross came up on Monday morning, he was astonished to see the barns and fences for miles outside the town covered with these posters. He concluded that Watson had some business tact in him, and was not mistaken. The concert passed off most successfully. There was a crowded house, comprising the élite of the town, and the audience were delighted.

The programme was a most varied one, comprising gems from Mozart and Beethoven, together with Yankee Doodle, Hail Columbia, 
and comic songs, ad libitum. It was repented with like success. Then they pushed on to St. John, thence to Portland, where crowded houses greeted them. The last concert was given in Gloucester, Watson's birthplace. It was a bumper, and the towns-people knew and recognized the talent which lie manifested.

Since then Prof. Watson has passed three seasons in Furope, where he has had the benefit of the best masters. Ole Bull sought him out, and he aceepted an invitation to spend the summer at his home in Norway. This distinguished violinist testified his appreciation of Watson's talents, by presenting him with one of his most valued instruments. The boy who gained his first instruction on board a fishing-schooner, and rejoiced in the possession of a one-dollar violin, has risen, step by step, until to-day he occupies a prominent position among the musical celebrities of the country. May he continue to prosper is our wish, as well as that of the fishermen from whose rank he is proud to state he sprang, aud among whom he acknowledges to-day some of his most steadfast friends.

\section{Loss of the Schooner "Neptune's Bride." - Two of the Crew saved. - Eighteen hours on the Mast- Head, - A Perilous Passage.}

Schooner "Neptune's Bride," as will be seen by the record, went ashore at Malcomb's .Lelge, Me., on the evening of September 22d, 1860. Twelve out of the fourteen of her crew met a watery grave. The following.are the full particulars of that night of peril :-

The vessel struck the ledge at a little past nine o'clock in the evening. It was quite foggy, accompanied with rain, and the men had all turned in except the watch on deck. She was jogging under a foresail, and, as soon as she struck, the men below rusherl on deck, and made for the boat. Mr. Marsh, and George Norwood, seeing that the boat was full, concluded to take their chances on the ressel. The boat was soon swamped by the heavy sea, and the men took refuge on the ledge. The tro on the vessel could distinctly hear them conversing, and they asked for a rope, as the ledge was a sunken one, over which the tide rose, and they wished to regain the vessel. Two attempts were made to get a rope to them, both proving unsuccessful. 
They then asked for some clothing; but the vessel was full of water, and none could be obtained. The schooner had now heeled over, and it was feared that she would capsize; but she remained in position. The tide was rising, with a heavy sea running, rendering it imperative for the men on board to go aloft, if they wished to save their lives. They crawled out on the bowsprit, and, while attempting to climb up the jib-stay, were washed off three times; but finally, after much toil, climbed up to the foremast-head, nearly exhausted with their struggle with the breakers. Here they clung, and while holding on in the darkness, heard the men on the ledge talking of their chances for life, and earnestly wishing that they could only get on board the vessel.

Slowly crept the moments, and the tide rolling in with each heaving billow. They heard their shipmates, as they moved as far up out of the reach of the greedy waters as possible, and, during the next hour, could not avoid hearing their struggles, as the sea rose, crested with raging foam, and claimed one after the other as its victim. Then the vessel's bow settled, bringing the two men up to their chins in water, as they stood on the foremast cross-trees. Norwood was discouraged at the cheerless prospect, and determined to swim for it, and left his position, hoping to gain the shore; but the sea was too much for him, and bidding his companion farewell, with the words, " $O$ my God!" upon his lips, sank beneath the waters.

As soon as Norwood left, Marsh determined on one more struggle for life, and, climbing up the foremast head, grasped the top-maststay and walking as far as he could on the spring-stay, pulled himself up, hand over hand, to the top-mast head, where he sat down and rested himself. His thoughts were of home, of his wife and child. An ardent desire to see them once more seemed to thrill his whole being, inspiring him with fresh courage. For their sake he determined not to succumb. The tide followed him and had now reached his feet, then up to his waist the waters came. There was so much comfort in sitting down, and he was so fatigued! But no! he must stand up if he wished to save his life, and so once more he stood up. To add to his discomfort, the rain came down, accompanied with thunder and lightning, and there, amid the darkness and the storm, he clung to the top-mast, hoping and praying for the dawn, and for the turning of the tide. He had suffered much from thirst; this he quenched from the rain-drops which wet his hair. He was in his stocking-feet, and suffered much from the cramped position in which 
be stood. One foot was raw where it had chafed against the springstay, and pained him soverely.

It was now, as near as lie could judge, about three o'clock in the morning, and he was in hopes that the tide was at the flood. He drew himself up, resting his chin on the color-truck. This was all he could do, and he patiently waited. The love of lifo was strong in the young man's heart, and he prayed that God would save hiln. Then he clung hold of the top-mast, and for a little time lost consciousness. When he came to, the dawn was breaking through the fog, and with joy unspeakable he saw that the water had gone down. He could see the top of the ledge peep out, from which his companions had met their death; and now, so far as he knew, he was the only survivor of them all. All day long he remained on the top-mast. The hours dragged, - oh, so slowly ! - filled with suspense, Lope, doubt, and sometimes despair. The tide turned, and slowly it crept toward him. The minutes now seemed hours; and yet no succor came. The water had crept up to his knees, and the prospect of another night on the wreck, together with the terrible expericnce and exposure of the past eighteen hours, were too much. He became delirious, and imagined that he was on board the schooner, beating up Portland harbor.

He was saved by the merest accident, if we may call such events accidents. Two fishermen were mending their uets on Seal Island. It bad been foggy all day, and at five in the afterfobon, when it cleared up, they saw the wreck, and one insisted that there was a man on the top-mast. His companion endeavored to persuade him that it was all imagination, and said it was of no use to go. But the other, convineed that he was right, replied that he would go alone if his companion would not accompany him. Both started, and what was their surprise, upon drawing near, to sec this poor fellow clinging to the top-mast, but utterly unconscious, raving with delirium. and yet holding on, his body submerged in water.

They rowed their boat alongside, then lifted him tenderly, and laid him down, putting their clothing over him; then le faintel. Carrying him ashore, to their little fishing-hut, they put him to beil with hot stones at his fect and back, and gave him strong herb drink dashed with a little liquor, which they happened to hare. In the morning he was hetter, and as soon as he conld be moved he was conveyed to Carver's Harbor, where he was taken to the hotcl, ani received the best attention; and from thence came home, and is alive to-day to tell of his peril that night, and of his wonderful escape. 
Henry Johnson, one of the crew who took to the boat, was also saved, after a night of struggle and hardship. While his shipmates sought refuge on the ledge, after the boat was swamped, he found himself alongside of her and crawled in over the stern-sheets. She was full of water, but fortunately there was a bucket in her, and a coil of rope. With the former he commenced bailing, and by dint of hard labor managed to free her, although she was continually taking in water. A hogshead tub from the vessel had drifted across the boat amidships. This he secured with his rope, and that made the boat ride more easily. When he got tired of bailing the boat he would crawl into the tub, and when that got full of water he would cornmence bailing the boat again. Two jibbing-tubs drifted near him. These he secured also, and making them fast on the other side of the boat, they helped to keep her afloat. He knew not whither he was drifting; but was thankful that he was.going away from the ledge, and so utterly exhausted was the poor fellow that, long ere daylight dawned, he fell asleep. He could not keep awake, though his life might depend upon it. On the boat drifted, being kept afloat by her tubs, and Johnson slept, perfectly oblivious to the seas which threatened to engulf him. "Tired nature's sweet restorer, balmy sleep," had possession of him, and on the boat drifted. At noon-time, a Belfast schooner sighted the craft, bore down to her, and her single passenger was received on board and kindly cared for. Thus, out of a crew of fourteen two alone were saved, after passing through hardships which makes one shudder to contemplate.

\section{Leaves from the Log-Book of Capt. James Pattillo.}

How he served a Dominion Officer, who boarded the Schooner Abigall. - Puts to Sea in the Teetir of a Gale, and outsalls the Cutter. - How he got a Load of Herring for Schooner 'Tiger. - A Fearfor Time on Georges, is Schooner Alexdinder.

Capt. James Pattillo, in his palmy days, was considered one of the smartest skippers that ever sailed from the port of Gloucester. When he was on board his vessel, he was the master, in every sense of that term; and if there were any fish to be got, he was the man to get them. For several year's he has retired from the water, and on his snug furm, at North Stoughton, is passing the evening of lis life in a 
quiet manner, enjoying himself, after his many years of battling the elements on the deck of a flshing craft. Now and then the captain comes to Gloucester. He must have a look at the harbor, and a snuff of the sea-breeze, enjoy a cruise aronnd the wharves, and a talk with his old companions. It was on one of these recent visits that we had an opportunity of interviewing him, and obtained the following spicy incidents, which form an interesting chapter in the "Merno rial and Record Book": -

In the year 1841, he made three trips to the bay, one for herring, and two for mackerel. It was the law then to pay fourpence a ton, light-money, each trip. On the third trip, a daughter of Dr. Cantrill, of Guysboro', N. S., who had been working in Lowell, wished to take passage. Her father had recently died, and the girl, in response to the urgent call of her mother, was extremely desirous of getting home, where she conld comfort her widowed parent, and do what lay within her power for the benefit of the family. Now it was against the law, in those times, for a fishing vessel to carry passengers; but the kind-hearted captain could not resist the appeal of the daughter, who wished to get home that she might assist her amieted relatives; so he consented to take her home. This he did on his own responsibility, without any compensation, save the satisfaction which the performanec of a good deed, in this world of ours, affords. Accordingly, she came on board; and upon the vessel's arriving at Canso, le carried her ashore in the boat. The ressel did not come to anchor, and while he was landing the girl, a custom-house officer, named Bigelow, came on board, and put the king's broad " $R$ " on the mainmast, which proclaimed lier a prize.

When Capt. Pattillo returned on board, the officer informed him that he had seized the vessel, for landing a passenger and her effects, contrary to law.

"Now, then," be says, "I want to see your papers."

The vessel's boat was hoisted in, and Capt. Pattillo went below to get his papers, and returning on deck with the documents, asked the officer if he thought himself the master of the schooner.

"Yes," was the reply.

Shortly after, he demanded of Capt. Pattillo the light-money; but he thought if the officer was really in command, he should pay the light-money himself and so informed him.

Then a lucky thought struck the captain, and he asks, in a stentorian roice, "By what authority he was on board the schooner, and where were his documents to prore that he was a revenue officer?" 
"I came off in such a hurry that I left them ashore," was the reply ; and this was true, as he had nothing to show.

"You base impostor!" roars the captain; "go ashore, you vagabond, as quick as possible."

But the officer was not going to give it up so quickly; so he ordered the helm hard down.

. Old John Parsons had the tiller, and he was so excited that he obeyed the order. Then Capt. Pattillo began to bristle up and sang out, "So long as I am on board this craft, Uncle John, I am master; now, then, hard up the helm!" This order was obeyed just in time to save the vessel from going ashore on Paint's Island.

- Then followed a war of words between the pair, in which skipper Pattillo was called a smuggler and other hard names; to which he replied, that all the crime he was guilty of, if crime it was, was bringing home a poor, fatherless girl, for which he asked no compensation; but right or wrong she was safe at home. Just then a little cutter made her appearance, and the exultant Bigelow said, "I have you now, anyhow, and will take the vessel into Great Canso Harbor."

"You can go where you like, cutter or no cutter, but the vessel will not carry the pair of us," was Capt. Pattillo's reply. "I'll heave to until you go ashore for your documents, and if you are the right man to receive the light-money, I will pay it; otherwise not." Thus they disagreed until "forbearance ceased to be a virtue," when Capt. Pattillo made a spring at the stout official, and seizing him by the throat with one hand, and taking him by the slack of his trowsers with the other, lifted him over his head as though he was an infant, and threw him into the boat so violently that he broke the thwart when he struck; then, casting off the bont's painter, let him find his way ashore as best he might.

But the end was not yet. He made complaint against the master of the Abigail for smuggling; and three cutters, commanded respectively by Capts. Darby, Marshall and Stevens, were sent in pursuit, with orders to take Pattillo, dead or alive!

Meantime skipper Pattillo pursued the even tenor of his way, and caught seventy barrels of mackerel. He had heard that they were after him, and had armed himself with two great rocks, weighing one hundred and fifty pounds each, to throw into and sink any boats which should attempt to board his vessel.

On the third of October there arose a feariul gale, and in the afternoon Capt. Pattillo run into Port Hood, and came to anchor 
with the rest of the fleet. Soon after, the cutter under the command of Capt. Marshall came in, and a boat containing eight men, fully armed and equipped, was sent to senrch among the vessels, to see if the Abigail and the big "Pattillo" was among them. Capt. Pattillo saw the movements, and stood by his large rocks, fully determined to drive them through any boat who dared to board his schooner. They saw him, and, considering " discretion to be the better part of valor," did not come alongside.

There was but one way to get out of this diffeulty, and that was to go to sea in the teeth of the gale. To remain where he was would result in his being captured; and to go outsidle was running the risk of getting ashore. But the plucky captain wris not long in making up his mind. Ile gave order's to get under wny.

Up went the sails. Skipper John Bayley, who wns anchored near, hove his xessel ahead as far as he could; and Ben. Laroque paid out his cable so as to give Pattillo all the adrantages he could in getting out. All was excitement, and the rigging of the fishing vessels and all along the shore was lined with spectators, anxious to witness the result.

The cutter now commeneed getting under way; but the Yankee fishing-craft had the lead, and passed within finy feet of the cutter. A ball was fired, which went through the mainsail. The men were ordered below, and the spunky skipper laid down flat on the deck and steered his craft. The next ball went through her side and lodged in the main-beam, where it may be seen to-day. Eleven shots were fired in all, five of which struck the ressel, and six came short. One struck the mainmast, taking off a glancing picce some four feet above deck. The cutter chased her six miles; but the fishing-craft was much the best sailer, and the galc increasing every moment, the cutter gave it up and went back, feeling rather chopfallen.

There was a gay time that night in the harbor; all the American fishermen took their hoats, and improvising $n$ band, with drum and fife, and other musical instrunents, played "Yankee Doodle," rowing around the cutter.

The Abigail iay to all night, right in the very worst of the gale, under balance-recfed mainsail and two-reefed foresail, and in due course of time arrived safely home. Among her crew now alive were Mr. Daniel Brown and Henry Smith.

In the year 1837 or '38, (the skipper could not exactly' recollect which, it was decided by Capt. Giles, who owned the pinkey Tiger, to send her to Fortune's Bay, Newfoundland, for a load of herring. 
This was an entirely new voyage, and skipper Pattillo, just the man to undertake it. He took with him five men and a black boy, and thinking there would be some nice game in those regions, carried five muskets and two liegs of powder. They started on the 28th of November, and after arriving were frozen up. Nothing daunted at this, they cut holes in the ice and succeeded in getting a load of herring, but they could not get out. There they were, hard and fast, with miles of ice between them and the clear water.

According to the old treaty, American vessels had no right to catch herring, or any other fish, within an imaginary three-mile line from the shore; and some one informed a Custom House officer named Gayden, that a Yankec ressel was getting herring, and he determined to seize and malse a prize of her. Now it so happened that the Tiger was out of provisions, and the Captain sent some of the crew a long distance ashore, where they purchased some flour and molasses. Some good friend of the Captain wrote him a letter and despatched it by one of the crew, in which he stated that Gayden intended to take the vessel, and was soon coming with a large force.

The Captain read the letter and then informed his crew. "Now, boys, we'll see about this. The thing can't be done! What, take the Tiger? Not by a long shot. We'll put her in such good fighting trim that all Newfoundland couldn't take her!"

Then they went to work and built four barricades of double logs, in such a manner that they swung at an angle of forty-five, commanding a complete sweep of the vessel, bullet-proof, and affording perfect shelter. When these were completed he swore his men on the Bible, that they would stick to him until the end, and so long as life lasted, they would obey his orders and fight for the old Tiger.

On the morning of March 11th, five boats were seen coming outside the ice, between Young's Point and Folly Cove Head. A clear place in the ice had been cut around the Tiger, in order to keep the foe at a respectful distance and give those on board a better opportunity to fire.

The Captain was right on his muscle that morning, and gave orders to load the muskets. They had been busy the day previously in running balls in a pistol-ball mould, and fifteen of these balls were placed in each cartridge. One keg of powder was placed in the hold, with a train attached, and the black boy had instructions that, at a given signal, he was to set fire to it and blow the vessel and all on board into atoms. The Tiger was not to be given up under any circumstances. They were all to share the satne fate, and they knew 
the Captain was just the man to carry out his plans. He would not flinch when the pinch came.

The boats landed on the borders of the ice, somo distance away. Captain Pattillo watched them through his glass, and counted thirty men, all armed to the teeth. Along the ice they marched, and reaching the clear plaee where the ressel was anchored, hailed her, wishing to see the master, and have him come ashore on the ice with his papers. It so happened that Captain Pattillo was not naturalized, and had used the name of Joseph Cain, as master, giving Cain his name for the time being.

After some little parleying Captain Pattillo informed them that his vessel was fully armed and provisioned to stand a siege. There were five muskets now covering them, containing in all seventy-five balls. "Now, you can't talie this vessel; and I propose to come ashore and decide this thing by a fair fight: Pick out three of your best men, and I'll take eare of them; but mind, if ye play me foul, there won't be one of ye who will ever see home again, as my men will fire when they get the signal from me."

The boat was got ready, and the captain, dressed in nothing but a pair of duck pants and slippers, with a handspike in one hand, and the vessel's papers in the other, got into her. John Gorman, one of the erew, rowed him ashore, and immediately returned to the ressel. The captain marehed boldly up to Gayden; then the men gathered around. One fellow stood with pistol cockecl over Gayden's shoulder, and two others with musliets drawn on the captain, all realy to fire. The papers were asked for, and handed over; then Gayden showed his credentials on parchment, also the silver oar, which gave him authority to board ressels. $\Lambda$ council was then held, and under the circumstances, (those formidable batteries, and the loacled muskets behind them,) it was deeided not to attempt to take the ressel, or eapture her captain. But the officer would not give the papers up, and marehed off with them.

April 17th, the Tiger was released from the ice, and went to Brunet, and on Sunday, the captain, taking one of the crew, Ned Carender, rowed in an open boat fifteen miles to Harbor Briton, for the purpose of ealling on Gayden and getting his papers, as he did not like the illea of starting for home without them.

His arrival ereatel a great excitement in the village, and men and boy's from far and uear gathered in squads to see the Y'ankec Captain, whose fame in arming his vessel had been wafted far and near. Knocking at the door of Gayden's house, a servant girl came, and he 
asked to see Mr. Gayden, who she said was at home. Then a little daughter came, and finally his wife, who wished to know if she could not attend to his demands.

"No, marm," said the skipper, "I want to see Gayden himself."

Finally he appeared, with a cocked pistol in his hand, trembling like an aspen leaf. He was so much agitated that he could not have held his hand steady enough to have hit the captain, even so close as they stood together, if he had tried his best.

"What do you want?" he sullenly muttered.

"I've come for my papers, sir," was the reply.

"They have been sent to St. John, and I cannot give them to you," was the next response.

"Then give me something to show that you took them." But he would not give him any writings to that effect. Quite a crowd had now gathered, among them an old magistrate and a policeman. The latter began to abuse the eaptain by insulting language, which be bore as long as he could, and then gave him a broadside clip under the ear, which landed him ten feet off, where he lay quiet, not caring much about getting up.

"If there are any more of ye who want anything of me come right along," said Pattillo ; "I'm not to be abused by any man living."

Nobody wanted anything; but the crowd cheered lustily, and he received an invite to go to the Jersey House to supper, which he promptly accepted, after which a vessel bound to Brunet, took their boat in tow and he rejoined his vessel.

In the mean time Gayden had got a cutter under way, manned with sixty-five men; but they were not smart enough to catch Pattillo. He was too wide-awake for them altogether, and he made a good run for Cape Ann, arriving May 14th. He had been absent so long that the vessel had been given up as lost, and when he went ashore they thought it was his apparition. But no, it was solid flesh and blood; and for many a day he was kept busy relating his adventures.

The herring met with a ready sale at $\$ 7.50$ per barrel, and were the first lot ever imported from Newfoundland into the United States.

On the 19th of February, 1841, Captain Pattillo sailed for Georges in the good schooner Alexander. On the 26th anchored at dark in thirty fathoms of water, twenty miles to the eastward of North Shoals. At midnight broke adrift, with the wind blowing a gale from the south-east. Got the anchor and set a double-reefed foresail and balance-reefed mainsail, and let her jog, 
with head to eastward. Told the watch to call him if the wind hauled. The wind shifted into the north-east with a tremendous gale and heavy sea. Tried to carry sail so as to clear the north shoal, but could not. Was soon of soundings and could not get bottom with a hundred fathoms. All through the forenoon the gale increased fearfully, the wind canting a little more to the northward. Had the leo rail under water, when all at once a tremendous sea raised the vessel perpendicularly in the air, and it seemed as if it would throw her end over end. He was standing in the companionway, and states that the vessel was completely enveloped in a sheet of water. He could look up under it, the same as one can gaze under the Falls of Niagara. Such a sight lie never before witnessed, nor did it ever occur before or since, to his knowledge, on Georges. Not a drop of water had touched the deck. William Blatchford, one of the erew, had his arm in the pump drawing the box, and never got wet a particle.

Soon this immense volume of water broke. The arch separated, and down it came, striking on the end of the bowsprit, breaking off both shrouds as clean as they could have been cut with a knife, severing the life-lines, splitting the end of the borsprit from the pallbits into the knight-heads, seventeen inches through. The sea went over the mast-heads, carrying away the main-topmast, end of the main boom, broke davits and boat, yet not a kogshead of water came on deck. The vessel was worked into port, and, after being repaired, continued her season's work. 


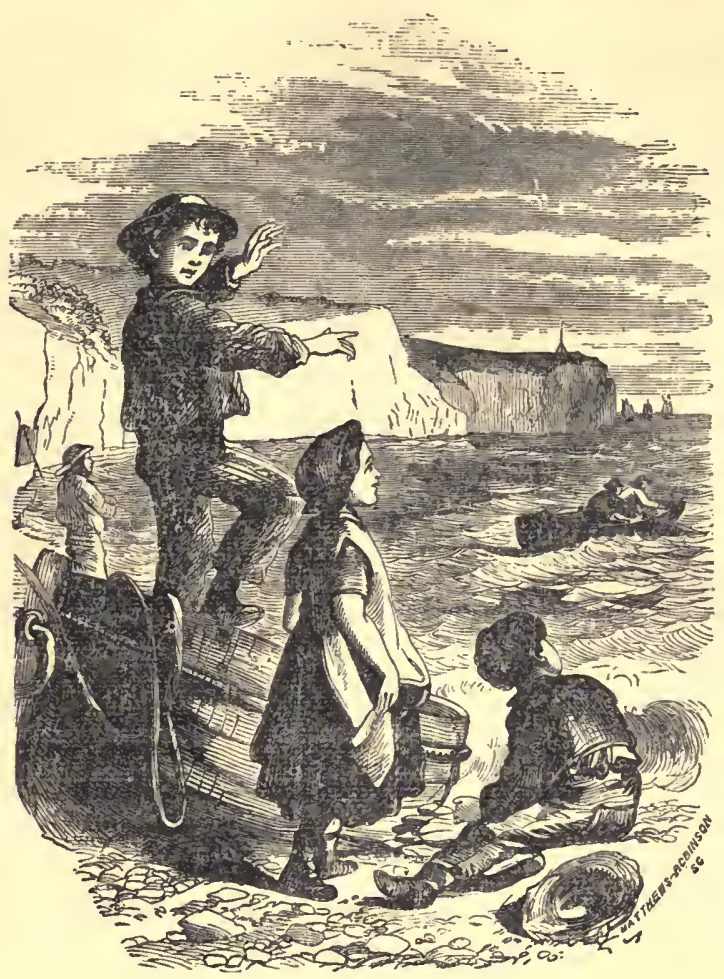

\section{"Here Comes Father's Vessel."}

"Here comes father's vessel!" How the picture leaps into life as we look at it! The colors grow rich and deep. We can see the blue sky overhead with golden clouds like fleets of bright ships sailing with the wind. The sea widens and lies flashing and heaving before us; and we hear the sound of the water as it rolls and rolls away.

"Father's vessel's coming!" How the children's faces laugh! What rejoicing is in their expression, in their very attitude! You can imagine that pretty soon, as the schooner sweeps nearer and nearer over the waves, the boy in the old fishing-boat will swing his cap and shout; that the girl will clap her hands and dance, and wave her apron with joy; while the lad sitting on the beach will lend his voice to the happy chorus, "Here comes father's vessel!"

There is a back-ground to this picture which we cannot see, but we can imagine it. It is in the town, now the city of Gloucester, 
with strects lying quict in the summer sunshine. The leaves on the trees rustle, the windows of the houses are open, and green vines are planted, and gay flowers blossom. Sometimes, now and then, a face cones to the window or the door, and looks out seaward; while a prayer is breathed for the safety of "father's vessel."

Perhaps, in one of the houses, there is a woman walking up and down the room getting dimner ready, and a baby lies sleeping in the cradle, which she stirs now and then with her foot as she passes. She is singing a fisherman's ballad; but there is a little shadow on her face, for she is thinking of "father's vessel." It lias been gone but a few days, perhaps, on Georges Bank; or it has been several weeks in the Bay, and there has been a violent storm; consequently the loved ones at liome are waiting anxiously for tidings of it. And now she hears a joyful ring of voices, and her face grows radiant as the children come bursting into the house, bringing the glad news, "Here comes father's ressel!"

In the great journey of life we are all of us going our different ways, doing our own work, of which otliers perhaps get the sweetness, while wo only have the pain of toil. The spinner spins his bright threads into soft clothe, which others will make up into beautiful garments; the writer plans in trouble and weariness the tender story which others will read in the sunshine of happy homes; and the fisherman braves the hardships and perils of a trip off on Georges, or the treacherous Bauks, in order to secure a choice luxury for another man's table. We all of us go our own way, and are not apt to give much time thinking of the toil and trials of others.

Yet sometimes, when we trifle with a delicious bit of fish at dinner, a thought comes to us of the great sea out of which it was caught. Perhaps a life was given for this same dainty morsel we are eating. Perchance the vessel was wrecked, and, drifting with torn sails and broken spars, had a terrible hard time of it. It is not a pleasant picture. We like better to think of the sehooner slowly rounding the Point. We like to think of the water flashing and heaving in the sunlight; of little children clapping their hands, dancing and shouting; and waiting wives and mothers thanking God with happy tears in their eyes, as the joyful cry rings out over the beach, "Here comes father's vessel!" 


\section{A P P E N D I X.}

IT was the intention of the author to have had this "Memorial and Record Book" published on the 20th of September, and it would, undoubtedly, have made its appearance promptly, but for the fire of August $27 \mathrm{th}$, which commenced in Bergengren's Block, and extended its ravages to the "Old Corner" building, destroying all the type, injuring the presses, and completely disarranging the business of the establishment. The sheets of the book, comprising one hundred and twelve pages, together with the advertising department, were badly injured by fire and water. Such of them as were in suitable condition were saved, and the balance has been re-printed. There were also twenty-four pages in type, which were to have been put to press immediately. These were lost, manuscript and all. The labor of re-writing these pages, mostly from memory, together with procuring electrotypes, as all of the original number were destroyed, can be understood only by those who have had a similar experience. It has been pursued indefatigably, in addition to other extra duties which the fire brought in its train, and it is with extreme gratification that we put these last sheets of manuscript, representing the conclusion of the Memorial Book, into the hands of the printer, feeling that the delay has been no fault of ours, and that we have been very fortunate, indeed, in being enabled to publish the book so quickly after the occurrence of such disastrous circumstances.

By the delay, we have had opportunity of adding a sad chapter containing the terrible disasters caused by that fearful storm of Sunday, August 24th, in the Provincial waters, in which so many of our fishermen were lost, and so much property destroyed. The record is, indeed, a fearful one, and the loss of life terrible to contemplate. It has sent a gloom over this community, completely changing the prospects of the Bay flect, which lad looked so bright and promising. Fire and flood held ligh carnival during that last week in August, and it only remains for our people to look forward, and not back upon the past, doing all within their power to retrieve their losses, 
keeping up that courage which has sustained them so often in adversity, and firmly believing that the tide which has set so strongly against them will soon turn, and bear them on to a greater degree of prosperity than ever before experienced.

\section{THE TERRIBLE GALE OF SUNDAY, AUGUST 24, 1873. ITS FEARFUL CONSEQUFNCES !}

Like a clap of thunder from a cloulless sky came the rumor into town, on Tuesday, August 26h, that there had been a terrible gale to tho eastward, extending all along the Canadian shores, carrying destruction in its pathway by sea and land, sweeping, with sad havoe, among the fishing-flect in the Bay of St. Lawrence and around Prince Edward's Island. Gloucester had one hundred and thirty-eight of her vessels in those watcrs, and the anxiety to hear from them was most intense. It was also feared, and it has proved too true, that the gale hat extencled to Georges Banks, where there was quite a fleet. 'The news eame slowly, and the reports at first were somewhat contradietory. But sufficient was received, during the next day and evening, to convince our people that it had proved one of the most terribly disastrous storms that ever occurred in those waters; and those having friends there began, as best they could, to prepare their minds for intelligence of another large loss of life. It was painful to witness the anxiety which pervaded this community, and to notice the attendance at the Gloucester Fishing Insurance Company's Reatling Room, as the bulletins were displayed from time to time. The newspapers were full of the disasters which the storm had oceasioned, the reading of which was most appalling. Houses were blown down, trees torn up from their roots, and the tidal wave which accompanied the storm, carried the wrecked ressels far above high-water mark, and left them stranded on the shore. Wharves were destroyed, and desolation and ruin followed in the track of the storm. Day by day the sad news came, and there is mourning throughont the town as we pen this article. Wires are weeping for their husbands, who will never again bless them with their earthly presenec; sisters are mourning for brothers, and little children ask, in plaintive roices, "Why does not father come lome?" It is, indeed, terrible, this news from the fishing-llect; and the loss of life, before which all other losses siuk into utter insignificance, is greater than by any other one gale since the tishing business commenced. 
The nearest approximation to it was the gale of Feb. 24th, 1862, when, fifteen vessels were lost with all hands, on Georges, numbering one hundred and twenty men. In this gale there were nine vessels lost, with all hands, which, together with those swept overboard from other vessels, number one hundred and twenty-eight men. Many of these were among the very best skippers and smartest fishermen of the port, whose loss will be felt for a long time by the entire community. Here is the record:-

VESSELS LOST IN THE BAY, WTTH ALL THEIR CREWS.

Schooner CHARLES C. DAME, wrecked off North Cape. Had a crew of eighteen men, as follows: William V. Beverage, master; Walter Hubbard, Lewis Thompson, Charles D. Perkins, George Hinckley, James Yoe, Charles Brown, Charles F. Payne, John McDonald, George W. Flowers, Stephen Morrison, Daniel McEachren, J. S. Emmons, Lemuel Emmons, R. A. Douglass, John Edgerly, Oakley Dodge and Henry Stebbins. Owned by Daniel Sayward. Valued at $\$ 7,000$; insured for $\$ 6,325$.

Schooner ANGIE S. FRIEND, probably foundered at her anchors, as portions of the wreck were washed ashore at Port Hood. She had a crew of fourteen men when she left port, two of whom left the vessel in the Bay and returned home, and their places were probably supplied by others from the Provinces. The following are the names of the crew : Adolphus Emery, master ; Robert Rowe, George Hunson, Joseph A. Hunson, his son, Augustus Cromwell, James Rien, Eugene M. Cromwell, Jacob H. Emery, Thomas Wilson, Charles Hustins, Joseph Small and James Robinson. Owned by Joseph Friend. Valued at $\$ 4,700$, and insured for $\$ 4,113$.

Schooner JAMES G. TARR had a crew of eighteen men, viz.: James Cushing, master ; James Hunson, father-in-lar of Capt. Cushing, who had his son with him; George Gould, brother-in-law of Cushing; Edward Gould and Abraham Gould, brothers of George; Daniel Chisholm, Stephen Ryan, married Chisholm's sister; Zimri Carter, Robert Carter, John McIntire, William H. Crittenden, D. J. McKennon, Joseph King, Angus McCormack, William Jackman, R. J. Hendricks and John McPhee. Owned by Leighton \& Co. and the master. Valued at $\$ 6,400$; insurance on vessel and outfits, $\$ 6,100$.

Schooner ROYAL ARCH, lost at White Head, N. S., on her passage home. Her crew numbered fourteen men, as follows: William 
C. Day, master ; Patrick Glenn, Nicholns Joy and his two sons, l'ate rick Ruxton, Charles H. Day; Elins Day, his son; Thomas Younger, William H. Morey, Everett Tillson, Joseph Boker, Danicl McDonald and Alfred Hill. It is supposed that Mrs. Dougal MIcIsane and four children took passage in this schooner for Gloucester, and were lost. Vessel owned by D. C. and H. Babson. Valued at $\$ 6,500$; insured for $\$ 5,600$.

Schooner SAMIUEL CROWELL left the Bay the day before the gale for home, and probably founclered at sea. She had a erew of fifteen men, viz., James W. Hamilton, master ; George Barrett, John Jeffrey, Jonathan 'Taylor, Samuel Taylor, son of Jonathan; Albert Barber, Robert Grant, Alexander MeDonald, Andy Paul, John Russell, John B. Marshall, David Martin, Charles P. Verrill, George Melvin and William Norris. Owned by William Parsons, $2 d \&$ Co. Valued at $\$ 6,000$; insured for $\$ 5,250$.

Schooner EL DORADO was probably lost upon White Head. She had a crew of seven men, all belonging in Kittery, Maine, as follows: Abraham S. Deering, master; Edward Deering, his son; Furber Fleteher, Clarence Fernald, Josiah Patch, Augustus Tobey, Jr., and Erastus Locke. Owned by James Mansfield \& Son. Valued at $\$ 1,300$; insured for $\$ 1,137$.

\section{LOST ON GEORGES.}

Schooner CENTRE POINT was probably lost in the gale of August 24th, as she was last seen adrift on the Bank that day. Her crew comprised eleven persons, viz., James Hastings, master; had his son with lim; William O'Brien, James Carsons, Antone Rose, Hugb MeEachren, Peter Peterson, Thomas Kecfe, Frederic Wilson, Charles Erickson, Edward Burns supposed to have been on board. Owned by Dodd, Tarr \& Co. Valued at $\$ 3,500$; and insured for $\$ 3,063$.

Schooner $\Lambda$. H. WONSON was probably lost in the same gale. She had a crew of ten men, as follows: Harvey Crowell, master; John Hanson, Simon Smith, Archic Rankin, Edward Spinney, Solomon Ryder, Peter Anderson, Thomas Cook, Thomas Blake and Charles T. Pattorson. Owned by Leighton \& Co. Valued at $\$ 6,000$; and insured for $\$ 5,250$. 
IN THE BANK FISHERY.

Schooner HENRY CLAY left the Grand Banks three days before the gale, and was lost on the passage home. She had a crew of ten men, as follows: Neil McFadden, master; Daniel McFadden and Alexander McFadden, brothers of the master; John McFadden, William Tucker, Daniel McKeever, Matthew Rice, William Dumphy, Angus McPhee. Owned by Solomon Pool. Valued at $\$ 4,200$; and insured for $\$ 3,675$.

LIST OF STRANDED VESSELS.

The number of vessels stranded in Provincial waters, in this gale, was thirty-two, as follows :-Addie M. Story, Amos Cutter, Arizona, Annie C. Norwood, Belle Gilmore, Charles P. Barrett, C. P. Thompson, Catalina, Charlotte Augusta, Clytie, Constitution, D. H. Mansfield, Evangeline, Electric Flash, Enola C., E. L. Rowe, Elihu Burritt, Freedom, Highflyer, J. J. Clark, Knight Templar, Lydia A. Harvey, Morning Star, Marion Grimes, Oliver Eldredge, Typhoon, Tally Ho, Wm. H. Raymond, Wm. A. Pew, Mary S. Hurd, Far West and Centurion.

Five of the above have proved total losses. Twenty-four have been got off, leaving three ashore at the present writing, which it is expected will be saved.

VESSELS STRANDED AND CONDEMNED.

Schooner MARY S. HURD, wrecked at Cape Canso, owned by James A. Stetson; valued at $\$ 3,000$, insured for $\$ 2,700$. Crew saved.

Schooner FAR WEST, wrecked at Port Mulgrave, owned by Dodd, Tarr \& Co. Valued at $\$ 2,200$, insured for $\$ 1,400$. Crew sared.

Schooner CENTURION, wrecked at Ship Harbor, owned by Samuel Haskell, Jr. Valued at $\$ 1,000$, insured for $\$ 825$. Crew saved.

Schooner TYPHOON, wrecked at Harbor Le Bar, crew saved. Owned by D. C. \& H. Babson. Valued, with outfit, at $\$ 3,700$; insured for $\$ 3,000$.

Schooner D. H. MANSFIELD, wrecked at Magdalene Islands; crew saved. Owned by George W. Plumer. Valued, with outfit, at $\$ 2,100$; insured for $\$ 1,888$. 
Schooner WFST POINT was lost at Magdalene Islands, September 20 th; crew saved. Owned by Perkins Brothers. Vulued, with outit, at $\$ 3,800$; insured for $\$ 3,300$.

LOST OVERBOARD.

Cinarles Rose and William Wilson, from schooner Franie R., in the Bay.

Antone Lewis, from schooner Helen M. Crosby, on passage to the Bay.

Josepil Christen, from schooner Dictator, on Georges.

Henir Johnson, from sehooner Sultann, on Grand Bank.

Frederic Carman, from schooner Abigail, on passage from the Bay.

OTHER LOSSES SLNCE JULY.

Schooner WILLIAM BAILIES, ballast lighter, was totally lost at Cape Hedge, near Milk Island, on the 6th of August. Crew saved. Valued at $\$ 800$, and uninsured. Owned by George M. Wonson of East Gloucester.

Frank Annerson, of Schooner Dietator, was lost overboard on Georges, September 1st.

Bromley Larkis, of Schooner Fitz J. Babson, was washed from the jib-boom and drowned, September $2 d$, while coming from the Banks.

Edward Day, of Schooner Alfarata, was killed in the Bay of St. Lawrence, July 18th, in consequence of being struck on the head by the main boom.

VALUATION, INSORANCE, ETC.

The total value of the vessels lost in this gale is $\$ 62,500$; their insurance $\$ 53,914$, which, with but two exeeptions, is in the Gloucester Mutual Fishing Insurance Office. In addition to the insurance on the vessels totally lost, there will be quite a large amount to pay out on partial losses, expense of getting off the stranded vessels, etc.; probably not less than $\$ 40,000$.

The total number of vessels lost the present year, up to October 1 st (nine months), is twenty-eight, valued at $\$ 114,600$. Total amount of insurance, $\$ 98,940$. Total loss of life, one hundred and seventy-two, 
the largest number ever lost in one season, since the fishing business has been prosecuted from this port.

SUM TOTAL OF LOSSES FOR THE PAST FORTY-TITREE YEARS.

Our table of losses, on page 53, included the number of men and vessels lost from 1830 up to the middle of July, 1873. The disasters and loss of life since, as given in the foregoing appendix, show a loss of one hundred and thirty-one men, and sixteen vessels; which, added to the previous list, swells the total loss of life, for the past fortythree years, to fourteen hundred and thirty-seven, and the total number of vessels to two hundred and ninety-six; an average of thirtyfour lives, and seven ressels yearly. Total value of ressels lost, $\$ 1,208,000$. Total amount of insurance, $\$ 893,439$.

Note. - On page 109 mention is made of the supposed loss of Mrs. Dougal McIsaac and four children in schooner Royal $A$ reh. After the first edition was printed, and too late to correct. the statement, it was ascertained that they were not on board. They subsequently arrlved home at Gloucester.

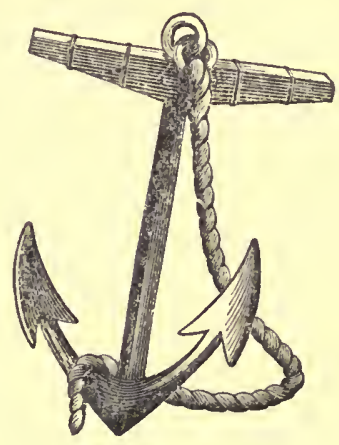




\section{CARTER'S}

Standard Oil Clothing BLACI AND YGLTOW.

Having had a large and practical experience with the wants of the

\section{FISHERMEN AND SEAMEN,}

and having devoted my whole time exclusively for years to the manufacture and improvement of
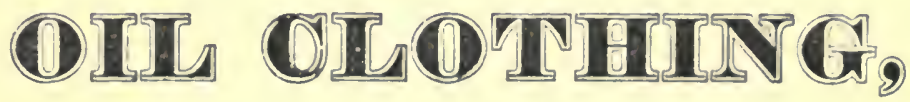

I claim a superiority for my goods over all other manufacturers, and offer them to the trade as the

\section{BEST IN THE MARKET!}

For the protection of the trade, all my goods are sold direct from the Manufactory, and all orders should be addressed to

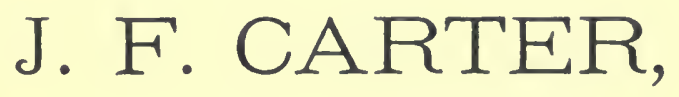

Manufacturer and Sole Proprietor,

Gloucester, (Cape Ann,) Mass. 


\section{H. G W. WORD,}

MANUFACTURERS OF

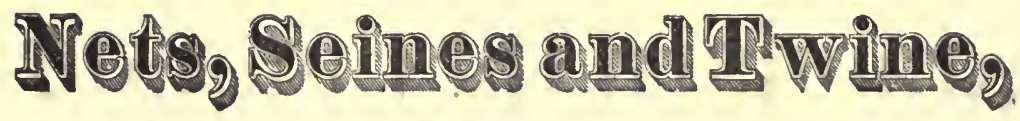

\section{No. 111 COMMERCIAL STREET, BOSTON.}

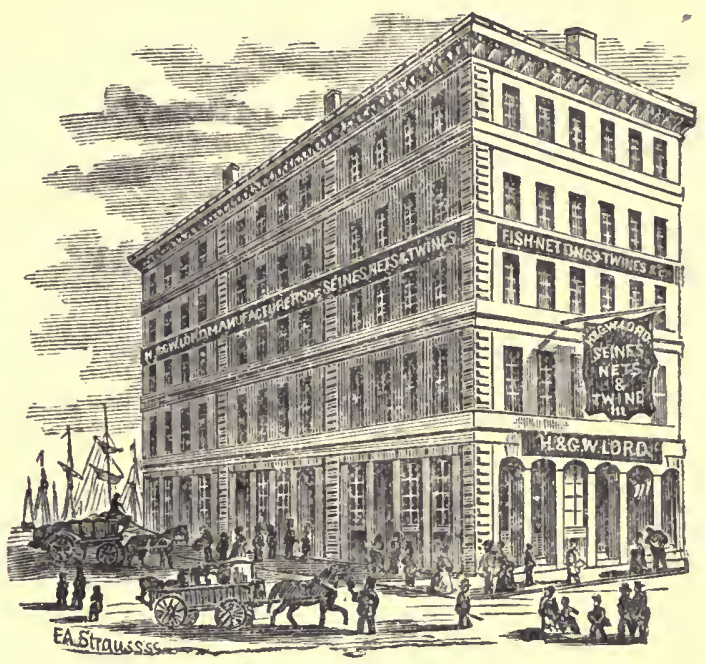

\section{Cloucester Seiners!}

\section{SEINE NETTINGS and SEINE FITTINGS!}

In consequence of our rapidly increasing business, we have already commenced manufacturing for the next season. Early orders will insure prompt attention.

We keep in our stock but one grade of MACKEREL SEINE TWINE NETTING, and that the very best manufactured in the country, without regard to cost.

PURSE MACKEREL SETNES fitted complete, ready for the water, of best materials, and at moderate cost.

\section{H. \& G. W. LORD,}

111 Commercial Street, Boston. 


\section{Attention, Fishermen}

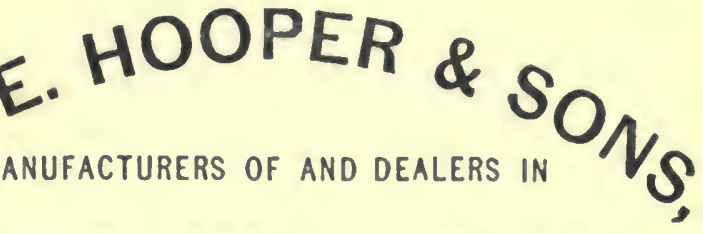

Twines, Netting, Cordage,

$-\mathbf{A N D}$

\section{WOODBERRY COTTON DUCK,}

OF EVERY DESCRIPTION,

Office, Cor. South and Pratt Streets,

\section{BALTIMORE, MD.}

\section{NOTICF.}

We are now making Netting on our New Machines, which is equal in all respects to that made by hand, and in many respects superior. $100 \mathrm{lbs}$. of twine made of 10 yarn knit on our Machines will make as much Netting in length and depth as can be made on any other machine now in use, and about 5 per cent. more than can be made by hand.

\section{Purse Seiners.}

We would call your especial attention to our 12 Thread Twine made of 16 Yarn; also, our Mackerel Netting made of 9, 12 and 16 Thread Twine of No. 20 Yarn. 


\section{JOHN BOYNTON'S SON,}

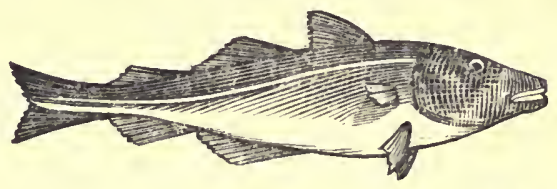

\section{General Commission Merchant}

FOR THE SALE OF

$\left.\begin{array}{l}\text { Vessels Chartered. } \\ \text { Freight Secured. }\end{array}\right\}$

\section{OFFICE, 32 BROADWAY,}

\section{A. W. ROWE \& BRO.}

\section{WHOLESALE}

\section{Commission Fish Dealers,}

$13 \& 14$ Delaware Ave., (Fish Market Dock St. Wharf,)

\section{PHILADELPHIA.}

$\left.\begin{array}{l}\text { A. W. ROWH, } \\ \text { WM. H. ROWH, }\end{array}\right\}$ - - Formerly of Gloucester, Mass.

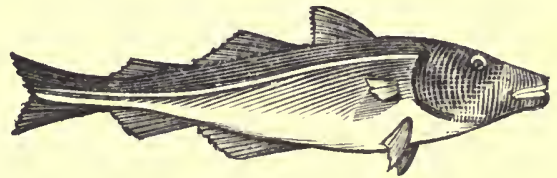

A. W. ROWE \& BRO. would call attention to their superior facilities for recciving and selling FISH of all kinds, and from a practical knowledge of the business, they can promise consignors that their interests shall be faithfully attended to. Particular attention will be given to the sale of

EROZEITHETIE,

and consignments are solicited.

Refer to SMiтh \& Gotr, Gloucester; M. W. Haskins \& Bro., Boston. 


\section{FISIEITIES.}

WE OFFER FOR 1874,

\section{HADLEY SUPERIOR PURSE SEINES.} Nets, Seines, Lines, Twines, \&c., made to order.

\section{AMERICAN NET \& TWINE} 43 Commercial Street, BOSTON, Mass.

\section{IIICGINS \& GITICORD, \\ YACHT AND BOAT BUILDERS,}

Seine Boats,

Sail Boats,

Row Boats,

Yawls.

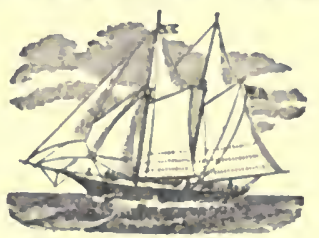

Dinkies,

Launches, Surf Boats, Canoes.

Manufactory at Head of the Harbor.

I'ost Oflce Address, Bux 930, GLOUCESXEN, Mass.

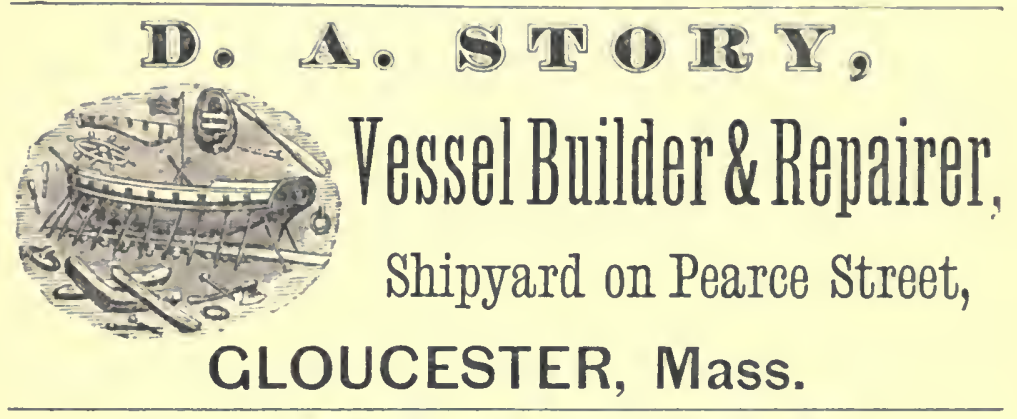

\section{DAVIS FOUSE,}

Opposite Bank of Oape Ann,

GLOUCESTER.

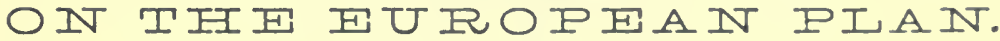

MEALS AT

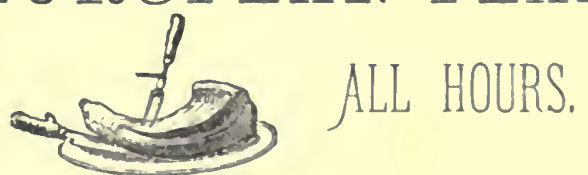

Rooms to Let to Gentlemen by the Day or Week.

Fish Dinners served up in all styles, on arrival of the Boat.

WM. P. DAVIS, Proprietor. 


\section{T王正}
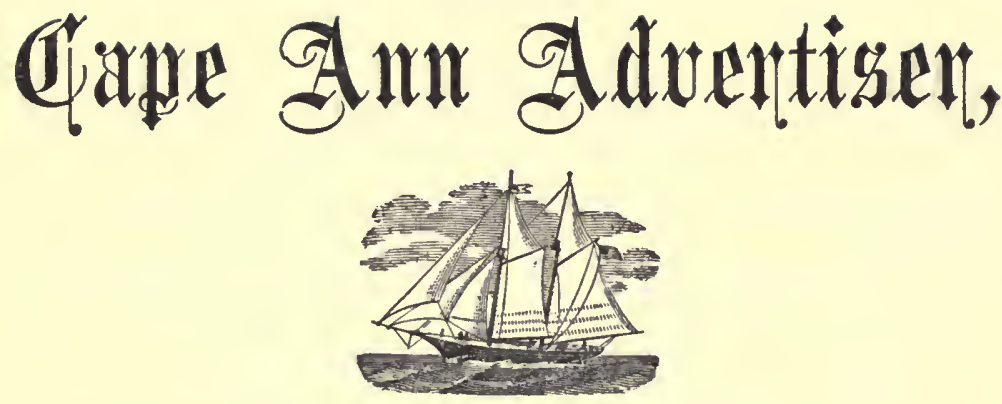

A handsomely printed sheet of Thmptr-Two Colums, issued every Friday morning, by

\section{PROCTER BROTHERS, GLoucester, MAss., EDITORS AND PROPRIETORS.}

Each issue has all the local news of Cape Ann, together with all the Fishing Items, a reliable Fish Market, Good Story, and choice Miscellaneous Reading Matter, making it emphatically

\section{The People's Paper!}

THE BEST ADVERTISING MEDIUM ON THE OAPE.

Circulation, 3,500 Copres. TERMS, \$2.50 per year, strictly in advance. Sent to any part of the country on receipt of price.

Subscribe for it if you wish to peruse a live local newspaper.

Connected with the Establishment IS A FIRST-CLASS

\section{JOB PRINTING OFFICE,}

Under the immediate supervision of Mr. IsaAC N. SToRy, where all kinds of Printing, from the largest Poster to the smallest Label, is executed promptly at fair prices.

Particular attention given to Commercial Printing, such as Check and Receipt Books, Letter Headings, Billheads, Bills of Lading, Notes, Drafts, etc. 


\section{CHARLES P. BARRETR. Merchant Tailor, \\ AND \\ Dealer in READY-MADE CLOTHING,}

HATS, CAPS, AND FURNISHING GOODS,

NFXT DOOR TO

Gloucester. Mass.

HATILLO'

THE WONDER OF THE AGE.

IIill s
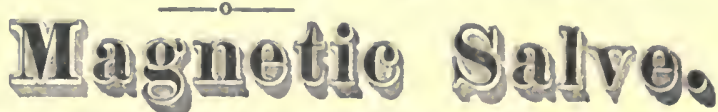

THOUSANDS CAN TESTIFY OF ITS VIRTUES.

Fishermen will find this Salve invaluable for the cure of Sore Hands. It worlis like magic. TRY IT.

It cures Old Sores, Salt Rheum, Bruises, Burns, Cuts, Frysipelas, Tunırs, Scroftla, Sore Lips, Weak Eyes, Chapped IIands, Piles, Boils, Ringworms, Itch, Frost Bites, Cancer, Scald Head, Chilblains, Pimples, Poison, etc.

For sale by A. F. PRICE, Gloucester, General Agent; GEO. C. GOODWIN \& CO., Boston, Wholesale Agents.

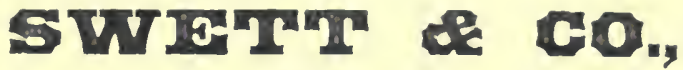

DEALERS IN

unmber, Barpels, Hoops, Hay, Straw, Brick, Lime, Cement, POTATOES, BEANS, dc.

WHARF ON COMMERCIAL STREET,

NEAR THE FORT.

GLOUCESTER.

Charts, Gunter's Seales, Spy Glasses, DIVIDERS, PARALLEL RULES,

BLUNT'S COAST PILOT, BOWDITCH'S NAVIGATORS,

CONBTANTLY ON HANI AT TIE

"OLD CORNER" BOOKATORE. PROCTER BROTHERS, 121 Front Street, Gloucester.

\section{On George"s in a Storm!}

TIIS BEAUTIFUI, PAIXTIXG has been photographed, and copies mns now he obtalned st the store of PROCTER BROS. It is a fine picture, ahowing two schooners riding at anchor, and another jogglng under a louble-reefed foresall. Just such a picture as every finhlig owner and fisherman wants.

Selling for $\$ 2.00$ and upwarda, aecording to style of frame. Whthout frame, 75 centh. Call and sec this picture. Seut by mail on reception of 73 cents.

Send 75 cents to Procter Bros., Gloucester, Mass, and recelve by return mall one of the above plctures. 
1846. "OLD Corner." I873.

\section{PROCTER BROTHERS,

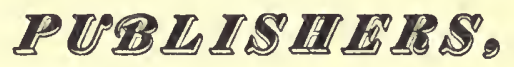

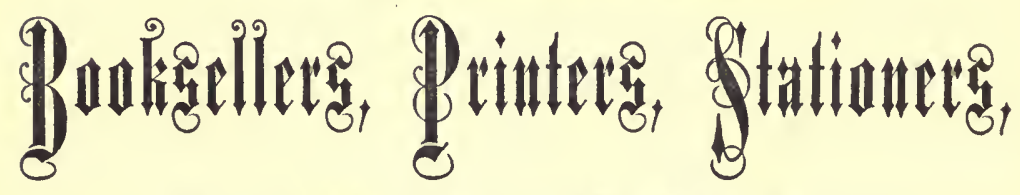
BLANK BOOK AND PICTURR FRAME MANUFACPURERS, ALSO, DEATERS IN

\section{ROOM PAPER, BORDERS,}

Window Shades and Fixtures, CÚTLERY, FANCY GOODS,

NEWSPAPERS, PERIODICALS, AND

\section{YANKEE NOTIONS GENERALLY.}

LARGEST VARIETY IN ESSEX COUNTY.

CIROULATING LIBRARY OF RECENT PUBLICATIONS.

H. E. \& J. P. DENNETT,

DENTISTS,

155 F GLOUCESTER, MASS. 


\title{
BENJ. H. SMTTH,
}

\section{Attoruey \& Counsellor at Law,}

\author{
WETEERELI'S BIOCK,
}

\section{CYEUS STOEY, \\ A UCTIONEFR,}

Real Estate Agrent, Justice of the Peace,

NOTARY PUBLIC AND CONVEYANCER,

89 Front St., Gloucester, Mass, Or First National Bank Building, opp. Post Offce.

\section{GEORGE A. BLACK,}

Upholsterer and Picture Frame Maker,

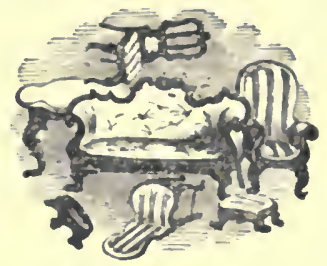

No. 177 Front Street, (up stairs,) Gloucester, Mass.

\section{DR. GIER. O. TUCK, \\ DIENTIST,}

Wetherell's Block, near the Post Onice,

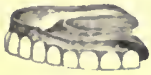

l'erforms all operatlons in Surgieal and Mechanleal Dentistry, in the best anner and at the lowest rates.

Prenent prices of Artitioial Teeth:-\$15.00 per set fur temporary, and $\$ 20.00$ for permanent, Including extracting with Langhing (isan or Fither.

00 Dr. H. A. Freman adviees his fricuds and furner patiente to call upon Dr. Teck when in need of the services of a Dentlat. 


\section{STEPHEN DODD \& CO.,}

Oommission Merchants, Wholesale Dealers and Ourers of

Dry, Pickled and Smoked Fish.

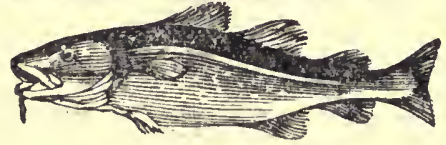

CEORGES CODFISH, SWOKED HALIBUT, IABRADOR HERRING.

GLOUCESTER NATIONAL BANK BUILDING, GLOUCESTER, MASS.

\section{SAMUEL ELWELL, JR.,}

MANUFACTURER OF

Patent Inside Iron Strapped Blocks, Oars, \&c., AND DEATER IN

WOODEN AND IRON SHIP CHANDLERY.

Steam Factory, corner Rogers and Duncan Streets, (between Cnstom House and Marine Railways,) Gloucester.

Carving and Gilding, Repairing Blocks of all kinds promptly attended to.

\section{MISS SA \\ SAWYER'S

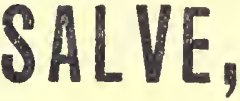

IS ACKNOWLEDGED AS THE BEST ARTICLE IN THE MARKET FOR THE CURE OF

\section{CUTS, BURNS, SORES, SCALDS, HUMORS, ETC.}

IF EVERY FAMULY KNEW ITS VALUE NONE WOULD BE WITHOU'T I'T.

Put up in Boxes at 50 Cents each. PREPARED BY

MISA C. SA W Y H RE, And put up by I. M. ROBBINS, WHOLESALE AND RETAIL DRUGGIST, ROCKLAND, • . • • . . - . MAINE. Sold Fiverywhere. 


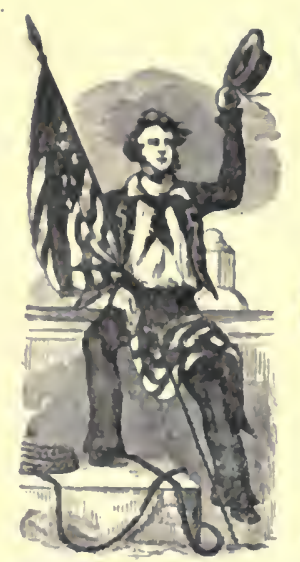

\section{Gureka Fish.}

Prepared Expressly for Family Use.

เบT บีเ แห

GEO.P.TRIGG \& CO.

GLOUCESTER, MASS.

This Flath in the cueapiat of any odinel to the publle, in aclected from cholce new Georgen Cod, amd propared realy fur une. thus avolding all wask and trouble in cooking.

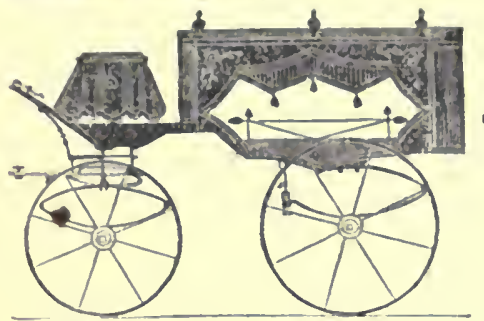

\section{JOHN LLOTD'S}

Undertaker's Wareroom,

Cor. Front St. and Western Ave.

Gloucester, Mass.

Comins, Casketa, Robes, Itahlts. Capm, \&c., constantly on haud. Chlldren's Rohen and

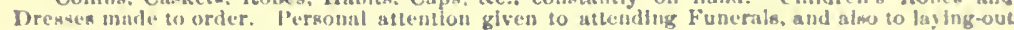
and preparing the dead for burlal.

\section{B. I ACKMIAI E CW.,} MANUFACTUREIS OF

All Sizes of FISHING LINES for Sea Fishing, FIROM 'THE IBES'L QUA LITY CUT'TON.

Jackman's Superior Sea Island COTTON MACKEREL LINES, LINEN LINES, GANGINGS, HAUSER LAID LINES, \&C.

Line-Walk \& Factory, 41 Marlboro St., Newburyport, Mass. A. M. BIRNAM, Agent at Houcrater.

\section{GEORGE E. ELWELL,}

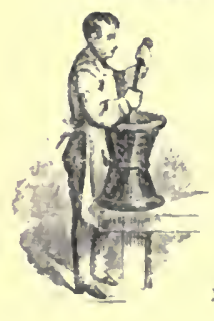

dinggist and dipotherary,

For the past eight years with A. E. I"rlce. would renpectfully announce that lo has taken the nore.

II2 FRONT STREET, OPP. PROCTER BROS.,

Where le offers for sale n carefulty nelected samurtacit of

Pure Drugs, Chemica! \& Pharmaceu:ica! Prepara:ioss, Eascy and Tollet Articles, \&.

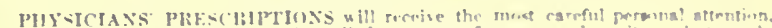

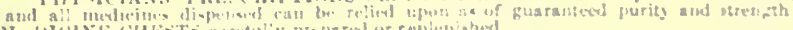
II iDICISE CIlLsTs curetuly prepared or sepienished. 


\section{GEORGI PRIEND CO.}

\section{N S P $\mathrm{E} \subset \mathrm{T} \odot \mathrm{E} S$, \\ AND DEALERS IN}

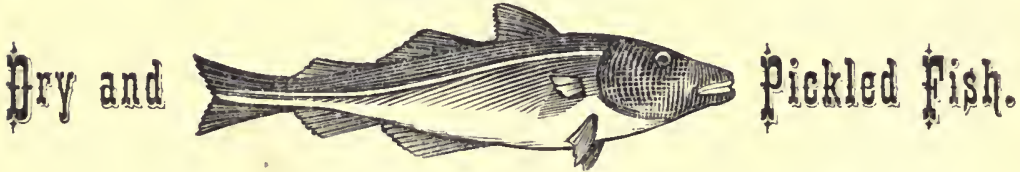

Vessels Outfits, Ship's Stores, etc., etc.

GLOUCESTER, MASS.

Fisk's Compound Elliptic Seat \& Bed Spring.

The Easiest Seat and Bed Spring ever offered to the Public.

The peculiar construction of the Fisk Spring, combining a series of Elliptics connected by wire rods. render it impossible to break down or get out of place, and being fully set up and adjuste.l for use, it can be upholstered at a saving of about one quarter of the labor and naterial required for the ordinary cushion, and forming an elegant shaped seat or bed unsurpassed for ease and durability.

Eprings for Car Seate, Lounges or Beds made to any size, and also to different degrees of strength and elasticity. offered.

The attention of the trade is called to the superiority of this Spring over any other ever

NATHAN RICHARDSON, Sole Manufacturer,

On Washington Street, near the Railroad Crossing, CLOUCESTER, MASS. BEND FOR A CIRCULAR.

ARTISTIO SHEIHS. STEREOSCOPIC VIETS OE
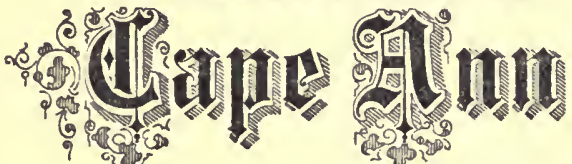

COMPRISING

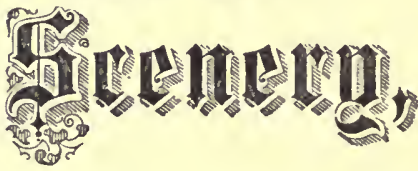

All the OBJECTS OF INTEREST which abound in this CHARMING RETREAT!

OLD OCEAN, with her white-winged fleet sailing across its pathless track;

The BEACHES,

The RUGCED COAST,

The QUARRIES,

LICHT-HOUSES,

CHASMS,

and PUBLIC"BUILDINGS,

forming a series which delight all who have seen them.

PROCTER Bbotilers, Publishers.

Send \$2.50, and let them forward you a Specimen Dozen. 



UNIVERSITY OF CALIFORNIA AT LOS ANGELES THE UNIVERSITY LIBRARY

UNIVERSITY OF CALIFURNIA

AT

LOS ANGELES

IIBRARY 


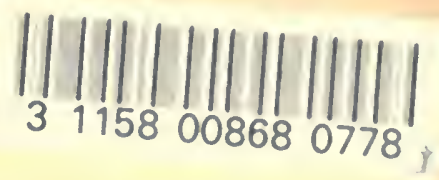

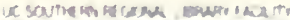

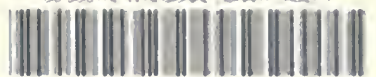

A 0013380092 
